UNIVERSIDADE DE SÃO PAULO

ESCOLA DE ENGENHARIA DE LORENA

LARISSA PEREIRA BRUMANO

Produção de biossurfactante por levedura utilizando fermentação em estado sólido em bagaço de cana-de-açúcar 



\section{Produção de biossurfactante por levedura utilizando fermentação em estado sólido em bagaço de cana-de-açúcar}

Tese de Doutorado apresentada à Escola de Engenharia de Lorena da Universidade de São Paulo para obtenção do título de doutor em Ciências do Programa de Pós-graduação em Biotecnologia Industrial na área de concentração: Microbiologia Aplicada

Orientador: Prof. Dr. Silvio Silvério da Silva

Edição reimpressa e corrigida

$$
\text { Lorena - SP }
$$


AUTORIZO A REPRODUÇÃO E DIVULGAÇÃO TOTAL OU PARCIAL DESTE TRABALHO, POR QUALQUER MEIO CONVENCIONAL OU ELETRÔNICO, PARA FINS DE ESTUDO E PESQUISA, DESDE QUE CITADA A FONTE

Ficha catalográfica elaborada pelo Sistema Automatizado da Escola de Engenharia de Lorena, com os dados fornecidos pelo(a) autor(a)

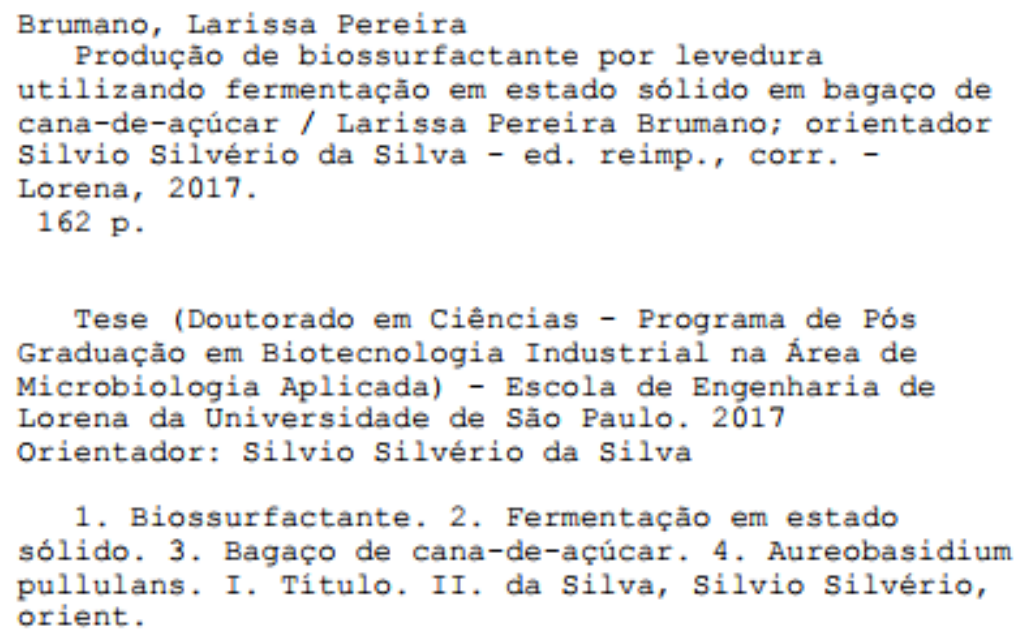


Dedico à minha família, presente de Deus, meus pais, Daniel e Cleuza, meus irmãos Danielle e Bruno e meus avós, em especial minha avó Madalena (in memorian), que sempre me apoiaram e torceram por mim em cada passo e me amaram de uma forma que me fizeram acreditar que tudo era possivel. 



\section{AGRADECIMENTOS}

Agradeço a Deus, pelas oportunidades e pessoas especiais que colocou em meu caminho, também por todo amparo e força nas dificuldades, que foram essenciais para que eu chegasse até aqui.

Ao prof. Dr. Silvio Silvério da Silva, por ter acreditado em mim e me apoiado desde o início. Por todo ensinamento e orientação que levarei para a vida. Agradeço as oportunidades e tudo aquilo que acrescentou ainda mais a minha formação. Meu sincero muito obrigada!

À profa. Dr. Miriam Aparecida de Oliveira Pinto, que me guiou desde os meus primeiros passos na vida científica e por me abrir as portas para este desafio. Obrigada pelo exemplo, confiança e por sua amizade incondicional.

Aos professores do Departamento de Biotecnologia, em especial Dr. Júlio César dos Santos, Dra. Maria das Graças de Ameida Felipe, Dra. Inês Roberto e Dr. Arnaldo Prata pelos ensinamentos, dedicação, amizade e apoio.

Ao Dr. Joachim Venus, Roland e Mary por me receberem tão bem e confiarem no meu trabalho.

Às alunas de iniciação científica e amigas Taciana, Maki e Sara, indispensáveis na realização do trabalho. Obrigada por toda a dedicação e por fazerem tudo mais fácil e divertido.

Aos colegas do laboratório Rafael, Sabrina, Itzcóatl, Matheus, Adriana, Kelly, Paulo, Leyanis, Guilherme, Ruly, Michelle, Juliana, Veridiana, Letícia e Júlia pela convivência no dia-a-dia, em especial aos amigos Felipe, Javier e Gilda pelos bons momentos, companheirismo e apoio constante.

Aos funcionários Nadir, Walkíria, Paulinho, Isnaldi e demais servidores do departamento, pela disponibilidade, sorrisos e boa vontade em ajudar sempre.

Aos amigos da pós-graduação pelos momentos de descontração, por trazerem alegrias no dia-a-dia e nas festas, em especial às minhas amigas e companheiras de república Isabele, Isabela, Fernanda, Luísa e Daiana pelos momentos dentro e fora da faculdade, pela amizade, carinho e conselhos que foram tão importantes para mim.

À minha família, meus pais Daniel e Cleuza, e irmãos Danielle e Bruno, pilares essenciais na minha formação, fonte inesgotável de amor, aprendizado, força e confiança de que mesmo com problemas tudo pode ter seu lado alegre.

Meus avós amados que mesmo distantes fisicamente sempre estiveram perto e torceram pelo meu sucesso. Aos meus tios e primos queridos que sempre acreditaram em $\operatorname{mim}$.

Ao Caio, meu amor, por todo carinho, paciência e apoio nas horas difíceis. Obrigada por me trazer tantas alegrias e acrescentar tanto à minha vida, me tornando uma pessoa melhor.

Por fim, agradeço aos professores da banca examinadora, pela atenção na leitura e sugestões desta tese e à CAPES, FAPESP, e CNPq, órgãos cujo apoio financeiro viabilizou este trabalho. 

"Nada na vida deve ser temido, somente compreendido. Agora é a hora de compreender mais para temer menos." (Marie Curie) 



\section{RESUMO}

BRUMANO, L. P. Produção de biossurfactante por levedura utilizando fermentação em estado sólido em bagaço de cana-de-açúcar. 2017. 162 p. Tese (Doutorado em Ciências) Escola de Engenharia de Lorena, Universidade de São Paulo, Lorena, 2017.

Biossurfactantes são moléculas anfifílicas produzidas por micro-organismos que possuem grande potencial na substituição de surfactantes químicos, pois apresentam maior biodegradabilidade e estabilidade. A busca por novos micro-organismos, matérias-primas e estratégias de produção é essencial para a viabilização da sua produção. Assim, a fermentação em estado sólido (FES) apresenta-se como uma tecnologia alternativa de produção, com a vantagem de evitar a formação de espuma, e a utilização de leveduras para o processo é vantajosa, pois muitas não apresentam risco de patogenicidade. O objetivo deste trabalho foi selecionar uma levedura capaz de produzir biossurfactante por FES, determinar as condições do processo, comparar com a fermentação submersa (FS), caracterizar bioquimicamente o biossurfactante e testar sua aplicação para biorremediação. Para tanto, 37 leveduras foram avaliadas quanto à produção de biossurfactante em caldo Kitamoto, por meio de testes das atividades tensoativa e emulsificante. Dessas, 17 apresentaram resultados positivos para tensoatividade, formaram emulsão estável e foram utilizadas para os testes em FES em 2 g bagaço de cana-de-açúcar e $10 \mathrm{~mL}$ de meio Kitamoto. Na FES, cinco leveduras apresentaram resultados positivos para tensoatividade e quatro formaram emulsão estável. Dentre essas, a Aureobasidium pullulans LB 83 foi selecionada por apresentar resultado positivo para tensoatividade, índice de emulsificação acima de $50 \%$ e estabilidade da emulsão. Foram testadas diferentes fontes de carbono, sendo a sacarose aquela que apresentou melhores resultados $(6,0 \mathrm{~cm}$ de tensoatividade no teste de espalhamento da gota (Ta) e $8,3 \times 10^{-2} \mathrm{~cm} / \mathrm{h}$ de produtividade em tensoatividade $\left(\mathrm{Q}_{\mathrm{Ta}}\right)$ ). A adição dos indutores glicerol (0 a $6 \mathrm{~g} / \mathrm{L})$ e óleo de soja (0 a $10 \mathrm{~g} / \mathrm{L})$ não apresentou efeito significativo para o processo. Também foi estudada a influência da aeração $\left(0,1\right.$ a $\left.1,1 \mathrm{~h}^{-1}\right)$ e da concentração de sacarose $(20$ a $80 \mathrm{~g} / \mathrm{L})$ utilizando planejamento fatorial composto de face centrada realizado em reator de tanque agitado. O uso das variáveis no nível mais alto aumentou a produção de biossurfactante $\left(8,05 \mathrm{~cm}(\mathrm{Ta})\right.$ e $8,4 \times 10^{-2} \mathrm{~cm} / \mathrm{h}\left(\mathrm{Q}_{\mathrm{Ta}}\right)$. As condições adequadas da FES foram avaliadas em frascos Erlenmeyer $(50 \mathrm{~mL}$ ) com $2 \mathrm{~g}$ de bagaço (suporte inerte) em um planejamento $2^{4}$, tendo como variáveis tamanho médio das partículas de bagaço $(0,6$ a 1,8 $\mathrm{mm})$, volume de meio adicionado (8 a $12 \mathrm{~mL})$, concentração celular inicial $\left(1 \times 10^{5}\right.$ a $1 \times 10^{7}$ cel $/ \mathrm{mL})$ e volume para extração $(15 \mathrm{a} 25 \mathrm{~mL})$. O tamanho das partículas apresentou efeito positivo e o volume de meio possuiu efeito negativo na concentração de biossurfactante. As demais variáveis não apresentaram efeitos significativos. Assim, as condições definidas foram $1,18 \mathrm{~mm}$ tamanho médio de partícula, $1 \times 10^{6} \mathrm{cel} / \mathrm{mL}$ concentração celular, $8 \mathrm{~mL}$ meio de cultura e $15 \mathrm{~mL}$ volume de extração, resultando na obtenção de 2,06 g/L de biossurfactante. Não houve diferença significativa entre o rendimento da condição otimizada na FES e a FS. A utilização de butanona para a extração mostrou-se vantajosa e o biossurfactante foi caracterizado como poliol lipídeo. Sua aplicação para biorremediação foi avaliada e apresentou maiores recuperações de petróleo da areia contaminada $(73,7$ e 78,4\%) que as obtidas por dodecil sulfato sódico (58,0 e 75,0\%), nas concentrações de 0,1 e $0,5 \%$ respectivamente. Concluiu-se que a levedura A. pullulans LB 83 foi capaz de produzir biossurfactante por FES e esse processo apresenta destacada potencialidade, podendo servir como conhecimento para futuros estudos visando sua implementação em escalas maiores.

Palavras-chave: Biossurfactante. Fermentação em estado sólido. Bagaço de cana-deaçúcar. Aureobasidium pullulans. 


\begin{abstract}
BRUMANO, L. P. Biosurfactant production by yeast in solid state fermentation using sugarcane bagasse. 2017. 162 p. Thesis (Doctoral of Science) - Escola de Engenharia de Lorena, Universidade de São Paulo, Lorena, 2017.
\end{abstract}

Biosurfactants are amphiphilic molecules produced by microorganisms that have great potential as substitute for chemical surfactants, since they present higher biodegradability and stability. The search for new microorganisms, raw materials and production strategies are essential for their production viability. Thus, solid state fermentation (FES) is presented as an alternative production technology, with the advantage of no foam formation, and the selection of yeasts for the process is favorable, since many of them do not present risk of pathogenicity. The objective of this work was to select a yeast able to produce biosurfactant by FES, to determine process conditions, to compare the results obtained by FES with the process of submerged fermentation (FS), to characterize biochemically the biosurfactant and to test its application for bioremediation. For this, 37 yeasts were evaluated for biosurfactant production in Kitamoto broth, using tests of tensoactive and emulsifying activities. 17 presented positive results for tensoativity and were able to form stable emulsion, and were used in tests of FES using $2 \mathrm{~g}$ of sugarcane bagasse and $10 \mathrm{~mL}$ of Kitamoto medium. In FES, five yeasts presented positive results for tensoativity and four were able to form a stable emulsion. Among these, Aureobasidium pullulans LB 83 was selected due to its positive results for tensoativity, emulsification index above $50 \%$ and emulsion stability. Different carbon sources were tested for biosurfactant production by $A$. pullulans LB 83 and sucrose presented the best results $\left(6.0 \mathrm{~cm}\right.$ of tensoativity in drop spreading test (Ta) and $8.3 \times 10^{-2}$ $\mathrm{cm} / \mathrm{h}$ of tensoactivity productivity $\left(\mathrm{Q}_{\mathrm{Ta}}\right)$. The addition of the inductors glycerol $(0$ to $6 \mathrm{~g} / \mathrm{L})$ and soybean oil ( 0 to $10 \mathrm{~g} / \mathrm{L})$ had no significant effect on the biosurfactant production process. The influence of aeration $\left(0.1\right.$ to $\left.1.1 \mathrm{~h}^{-1}\right)$ and sucrose concentration $(20$ to $80 \mathrm{~g} / \mathrm{L})$ were also studied using factorial composite face centered design in a stirred tank reactor. The use of the variables at the highest level increased biosurfactant production $(8.05 \mathrm{~cm}(\mathrm{Ta})$ and $8.4 \times 10^{-2} \mathrm{~cm} / \mathrm{h}(\mathrm{QTa})$. The appropriate conditions for FES process were evaluated in Erlemeyers flasks $(50 \mathrm{~mL})$ with $2 \mathrm{~g}$ of sugarcane bagasse (inert support) in a factorial design $2^{4}$. The variable used were bagasse particles size $(0.6$ to $1.8 \mathrm{~mm})$, medium volume added ( 8 to $12 \mathrm{~mL})$, initial cell concentration $\left(1 \times 10^{5}\right.$ to $1 \times 10^{7}$ cell/mL) and water volume for extraction (15 to $25 \mathrm{~mL}$ ). Particle size had a positive effect and medium volume had a negative effect on biosurfactant concentration. The other variables did not present significant effects. Thus, the defined conditions were $1.18 \mathrm{~mm}$ of particle size, $1 \times 10^{6}$ cell $/ \mathrm{mL}$ of initial cell concentration, addition of $8 \mathrm{~mL}$ of culture medium and $15 \mathrm{~mL}$ for extraction volume ( $2.06 \mathrm{~g} / \mathrm{L}$ of biosurfactant was obtained). There was no significant difference between the performance of the optimized condition in FES and FS. The use of butanone for the extraction was advantageous and the biosurfactant was characterized as polyol lipid. Its application for bioremediation was evaluated, exhibiting a higher recovery of contaminated sand oil (73.7 and 78.4\%) than those obtained by sodium dodecyl sulphate (58.0 and $75.0 \%$ ), at concentrations of 0.1 and $0.5 \%$ respectively. For these results, it was concluded that the yeast $A$. pullulans LB 83 was able to produce biosurfactant by FES and this process has outstanding potential, and can be used for future studies aimed at implementation of larger scales.

Key words: Biosurfactant. Solid state fermentation. Sugarcane bagasse. Aureobasidium pullulans. 


\section{LISTA DE FIGURAS}

Figura 1 - Estrutura dos surfactantes e sua distribuição entre as interfaces água/óleo e óleo/água, formando emulsão.

Figura 2 - Esquema das forças intermoleculares no interior e na superfíciedo líquido (A) e

formato esférico da gota (B), resultado da força de coesão das moléculas da superfície ........28

Figura 3 - Diagrama esquemático da variação da tensão superficial, interfacial e solubilidade

de compostos orgânicos com a concentração de tensoativos

Figura 4 - Biossíntese de precursores da produção de biossurfactantes a partir da utilização de carboidratos e/ou glicerol como fonte de carbono.

Figura 5 - Biossíntese de precursores da produção de biossurfactantes a partir da utilização de hidrocarbonetos apolares como fonte de carbono

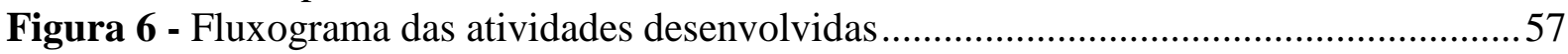

Figura 7 - Biorreator BIOSTAT BPlus 5L (Sartorius AG, Alemanha) ...................................66

Figura 8 - Esquema da câmara Agasse-Lafont-R .......................................................... 72

Figura 9 - Fluxograma da extração de açúcares residuais do bagaço de cana-de-açúcar........ 75

Figura 10 - Formação de halo devido à atividade hemolítica do micro-organismo em ágar sangue. Teste das leveduras SSS05, SSS06, SSS07 e SSS08 em duplicata............................. 86

Figura 11 - Aspecto da emulsão formada no teste de emulsificação para avaliação da produção de biossurfactante

Figura 12 - Avaliação do pH durante a fermentação em estado sólido utilizando A. pullulans LB 83

Figura 13 - Perfil de crescimento celular de A. pullulans LB 83 na fermentação em estado sólido utilizando os valores estimados de concentração celular.

Figura 14 - Resultados da abertura do halo no teste de espalhamento da gota durante a fermentação em estado sólido utilizando A. pullulans LB 83

Figura 15 - Correlação entre a concentração celular e a atividade tensoativa (avaliada pela abertura do halo no teste de espalhamento da gota) obtidos durante a FES sólido utilizando $A$. pullulans LB 83.

Figura 16 - Resultados dos testes em placa da produção de celulases $\left(\mathrm{A}^{*}\right)$, xilanases $\left(\mathrm{B}^{*}\right)$ e polifenol oxidases (C) por Aureobasidium pullulans LB 83.

Figura 17 - Mudança de coloração do cultivo de A. pullulans SSS 33 nos tempos de 24 h e $168 \mathrm{~h}$ em diferentes fontes de carbono (glicose, manose, sacarose, arabinose e xilose)........ 104 Figura 18 - Concentração de diferentes fontes de carbono durante o cultivo de Aureobasidium pullulans SSS33 em função do tempo de fermentação submersa 105 Figura 19 - Concentração celular de Aureobasidium pullulans SSS33 em função do tempo de fermentação submersa em diferentes fontes de carbono .

Figura 20 - Biossíntese de manitol a partir da sacarose e da glicose

Figura 21 - Perfil do crescimento celular, $\mathrm{pH}$, atividade biossurfactante e produtividade em tensoatividade nas fermentações utilizando sacarose (50 g/L) e glicerol (3 \% v/v) (SG); sacarose (50 g/L) e óleo de soja (5\% v/v) (SO); sacarose (50 g/L), óleo de soja (5\% v/v) e glicerol (3\% v/v) (SOG) e somente sacarose (50 g/L) (S) (fermentação controle) para avaliação da ação indutora de óleo de soja e glicerol para a produção de biossurfactantes por Aureobasidium pullulans LB 83 em fermentação submersa

Figura 22 - Gráfico de pareto com as variáveis dependentes Tensoatividade máxima e Produtividade em tensoatividade, de acordo com resultados das variáveis independentes (1) concentração de glicerol e (2) concentração de óleo de soja.

Figura 23 - Gráfico de Pareto para tensoatividade máxima $(\mathrm{cm})$ e produtividade em tensoatividade $(\mathrm{cm} / \mathrm{h})$ de biossurfactante, de acordo com a análise estatística do planejamento 
factorial completo $2^{2}$ realizado para avaliar a influência da (1) taxa de aeração (vvm) $\left(\mathrm{min}^{-1}\right)$ e (2) concentração de sacarose $(\mathrm{g} / \mathrm{L})$ no processo de produção de biossurfactante por Aureobasidium pullulans LB 83 em reator de tanque agitado

Figura 24 - Superfície de resposta (A) e linhas de contorno correspondente (B) para as respostas Tensoatividade máxima (Ta), considerando taxa de aeração e concentração de sacarose como variáveis independentes no processo de produção de biossurfactantes por Aureobasidium pullulans LB 83 em reator de tanque agitado.

Figura 25 - Superfície de resposta (A) e linhas de contorno correspondente (B) para as respostas Produtividade em tensoatividade $\left(\mathrm{Q}_{\mathrm{Ta}}\right)$, considerando taxa de aeração e concentração de sacarose como variáveis independentes no processo de produção de biossurfactantes por Aureobasidium pullulans LB 83 em reator de tanque agitado....

Figura 26 - Formação de espuma na fermentação submersa em biorreator (BIOSTAT BPlus de $5 \mathrm{~L}$, Sartorius AG, Alemanha). Concentração de sacarose $80 \mathrm{~g} / \mathrm{L}$, taxa de aeração $1,1 \mathrm{~min}^{-1}$ (A: $120 \mathrm{~h}$ de cultivo; B: $168 \mathrm{~h}$ de cultivo).

Figura 27 - Concentração de açúcares (sacarose, glicose e fructose) durante a fermentação para produção de biossurfactantes por Aureobasidium pullulans LB 83 em diferentes condições de aeração e concentração inicial de sacarose.

Figura 28 - Tensoatividade e biomassa durante a fermentação para produção de biossurfactantes por Aureobasidium pullulans LB 83 em diferentes condições de aeração e concentração inicial de sacarose.

Figura 29 - Aspecto final dos meios de cultivo após 168 h de fermentação em diferentes condições de aeração e concentração inicial de sacarose: diferença de coloração e viscosidade

Figura 30 - Relação entre a tensoatividade (diâmetro do halo obtido pela técnica de espalhamento da gota) $(\mathrm{cm})$ e a concentração de biossurfactante $(\mathrm{g} / \mathrm{L})$. A linha representa a regressão linear.

Figura 31 - Gráfico de pareto de acordo com resultados das variáveis independentes (A) tamanho médio das partículas do bagaço, (B) concentração do inóculo em células $/ \mathrm{mL},(\mathrm{C})$ volume de meio inicial de meio e (D) volume de água para a extração, referentes aos resultados do planejamento estatístico $2^{4}$ completo com cinco pontos centrais, para estudo de condições da FES da levedura Aureobasidium pullulans em bagaço de cana-de-açúcar...... 131 Figura 32 - Extração do biossurfactante com butanona e verificação de fluorescência ........ 135 Figura 33 - Cromatograma da análise da fração polar do biossurfactante hidrolisado em HPLC

Figura 34 - Aspecto da morfologia celular de Aureobasidium pullulans LB 83 antes (A) e após (B) a extração com butanona. (Microscopia óptica, aumento de 400x) 


\section{LISTA DE TABELAS}

Tabela 1 - Classes de biossurfactantes, característica de cada grupamento hidrofílico e seus

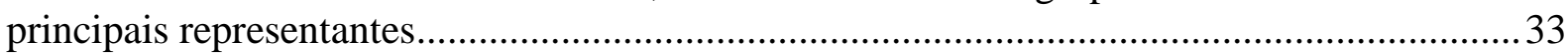

Tabela 2 - Funções, tipos e aplicações de biossurfactantes atualmente utilizados ................. 35

Tabela 3 - Principais métodos de seleção de micro-organismos produtores de biossurfactantes, seus fundamentos e desvantagens

Tabela 4 - Processos de downstream para recuperação de biossurfactantes importantes e respectivas vantagens

Tabela 5 - Utilização de resíduos e subprodutos agroindustriais como substratos para produção de biossurfactantes por diferentes micro-organismos.

Tabela 6 - Lista de espécies de leveduras utilizadas e seu respectivo código

Tabela 7 - Matriz do Planejamento Fatorial $2^{2}$ completo com triplicata no ponto central com valores codificados das variáveis independentes concentração de glicerol (\% v/v) e concentração de óleo de soja (\% v/v) utilizadas na produção de biossurfactantes por levedura

Tabela 8 - Valores codificados e valores reais das variáveis independentes concentração de sacarose $(\mathrm{g} / \mathrm{L})$ e aeração $\left(\mathrm{min}^{-1}\right)$ no processo de produção de biossurfactante por Aureobasidium pullulans LB 83.

Tabela 9 - Níveis codificados e valores reais do planejamento de experimentos $2^{4}$ para variáveis independentes: tamanho médio das partículas do bagaço, concentração do inóculo em células/mL, volume de meio inicial e volume de água para a extração, no processo de produção de biossurfactante em FES da pela levedura selecionada em bagaço de cana-deaçúcar.

Tabela 10 - Resultado dos testes de identificação de leveduras produtoras de biossurfactantes baseados na sua atividade tensoativa. Teste realizado após $72 \mathrm{~h}$ de cultivo em meio Kitamoto.

Tabela 11 - Resultado dos testes de identificação de leveduras produtoras de biossurfactantes baseados na sua atividade emulsificante. Testes realizados após $72 \mathrm{~h}$ de cultivo em meio

Kitamoto.

Tabela 12 - Resultados dos testes de espalhamento da gota e índice de emulsificação para avaliação de produção de biossurfactante por fermentação em estado sólido. Testes realizados após $72 \mathrm{~h}$ de cultivo utilizando meio Kitamoto como solução umedecedora

Tabela 13 - Resultados da caracterização do bagaço de cana-de-açúcar................................99

Tabela 14 - Estimativa da concentração celular durante a fermentação. *A estimativa realizada considerando a concentração celular retida no bagaço (baseada na concentração celular inicial da fermentação $\left(1 \times 10^{6}\right)$ e a obtida após extração da amostra, determinada na Câmara Agasse-Lafont.

Tabela 15 - Concentração de sacarose e glicose durante a fermentação nos cultivos preparados com sacarose como única fonte de carbono.....

Tabela 16 - Valores de espalhamento da gota $(\mathrm{cm})$ em função do tempo nas diferentes fontes de carbono testadas para a produção de biossurfactantes por A. pullulans LB $83 \mathrm{em}$ fermentação submersa

Tabela 17 - Valores de maior tensoatividade $(\mathrm{Ta})$ e produtividade em tensoatividade $\left(\mathrm{Q}_{\mathrm{Ta}}\right)$ para diferentes fontes de carbono (glicose, manose, sacarose, arabinose e xilose) e suas médias (teste de Tukey a 95\% de confiança).

Tabela 18 - Valores de maior tensoatividade (Ta) para diferentes fontes de carbono (glicose, manose, sacarose, arabinose e xilose) e suas médias (teste de Tukey a $90 \%$ de confiança) na fermentação em estado sólido utilizando bagaço de cana-de-açúcar como substrato 
Tabela 19 - Média dos valores de máxima tensoatividade $(\mathrm{Ta})$ e produtividade em tensoatividade $\left(\mathrm{Q}_{\mathrm{Ta}}\right)$ das fermentações utilizando sacarose e glicerol (SG); sacarose e óleo de soja (SO); sacarose, óleo de soja e glicerol (SOG) e somente sacarose (S) (fermentação controle) para avaliação da ação indutora de óleo de soja e glicerol para a produção de biossurfactantes por Aureobasidium pullulans LB 83 em fermentação submersa

Tabela 20 - Valores reais e níveis codificados das variáveis independentes concentração de óleo de soja $(\mathrm{g} / \mathrm{L})$ e concentração de glicerol $(\mathrm{g} / \mathrm{L})$ e resultados das variáveis respostas tensoatividade $(\mathrm{cm})$ e produtividade em tensoatividade $(\mathrm{cm} / \mathrm{h})$ para cada ensaio do planejamento estatístico $2^{2}$ completo com três repetições no ponto central, para estudo das condições de fermentação visando produção de biossurfactante por Aureobasidium pullulans LB 83

Tabela 21 - Planejamento fatorial completo $2^{2}$ com quatro pontos em face centrada e três replicatas no ponto central, de acordo com o planejamento fatorial composto de face centrada (CCFD), com valores das variáveis independentes taxa de aeração (vvm) e concentração de sacarose (g/L), para a produção de biossurfactante por Aureobasidium pullulans LB $83 \mathrm{em}$ reator de tanque agitado, com máxima tensoatividade e produtividade em tensoatividade como variáveis resposta

Tabela 22 - Análise de variância (ANOVA) para os modelos ajustados para a variável resposta tensoatividade máxima (Ta) e produtividade em tensoatividade $\left(\mathrm{Q}_{\mathrm{Ta}}\right)$ em função das variáveis estudadas taxa de aeração (vvm) e concentração de sacarose $(\mathrm{g} / \mathrm{L})$ no processo de produção de biossurfactantes por Aureobasidium pullulans LB 83 em reator de tanque agitado.

Tabela 23 - Níveis reais e codificados das variáveis independentes (A) tamanho médio das partículas do bagaço, (B) concentração do inóculo em células $/ \mathrm{mL},(\mathrm{C})$ volume de meio inicial e (D) volume de água para a extração, e resultados da variável resposta concentração produzida de biossurfactante para cada ensaio do planejamento estatístico $2^{4}$ completo com cinco repetições no ponto central, para estudo de condições da fermentação em estado sólido utilizando a levedura Aureobasidium pullulans LB 83 em bagaço de cana-de-açúcar. ........ 130 Tabela 24 - Comparação entre os rendimentos obtidos na fermentação submersa e fermentação em estado sólido após extração com água e com butanona 134

Tabela 25 - Remoção de petróleo residual de areia contaminada artificialmente utilizando-se soluções de biossurfactante (BS) $(0,01$ e $0,05 \% \mathrm{~m} / \mathrm{m})$, solução de dodecil sulfato de sódio (SDS) $(0,01$ e $0,05 \% \mathrm{~m} / \mathrm{m})$ e água desmineralizada $\left(\mathrm{H}_{2} \mathrm{O}\right)$ como soluções removedoras 139 


\section{LISTA DE SIGLAS}

BHL - Balanço Hidrfílico Lipofílico

CMC* - Concentração micelar crítica

CMC - Carboximetilcelulose

EE - Estabilidade da emulsão

FES - Fermentação em estado sólido

FS - Fermentação submersa

GRAS - Generally Recognized as Safe

HPLC - Cromatografia líquida de alta performance

IE - Índice de emulsificação

$\mathrm{mL}-$ mililitros

$\mu \mathrm{L}-$ microlitros

NREL - National Renewable Energy Laboratory

$\mathrm{pO}_{2}$ - pressão parcial de oxigênio

$\mathrm{Q}_{\mathrm{Ta}}$ - produtividade em tensoatividade

$\mathrm{Ta}$ - tensoatividade

$\mathrm{Rpm}$ - revoluções por minuto

vvm - volume de ar por volume de meio, por minuto

WHO - World Health Organization 



\section{SUMÁRIO}

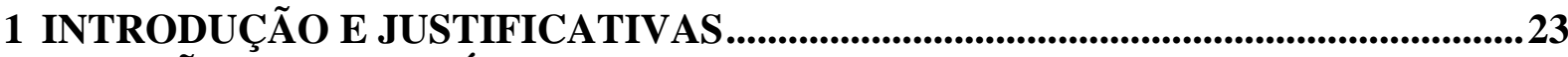

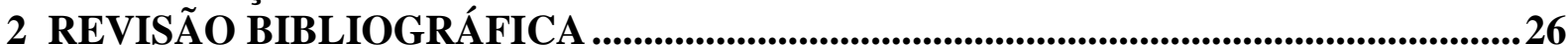

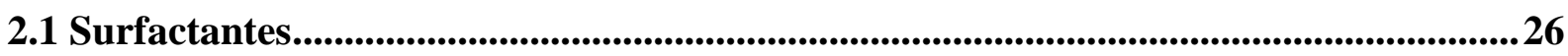

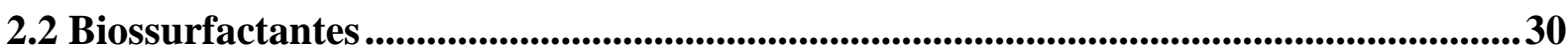

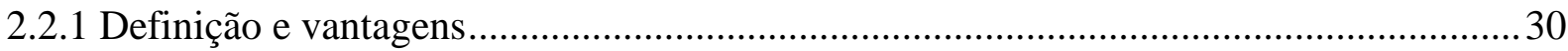

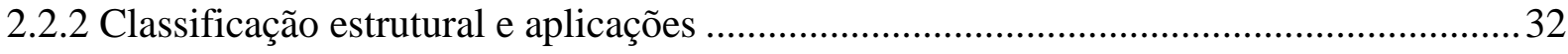

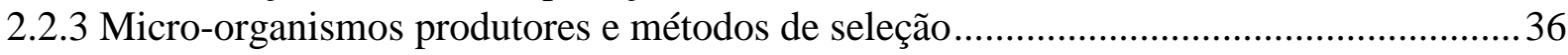

2.2.4 Vantagem da utilização de leveduras e fungos leveduriformes ("yeast-like")................ 40

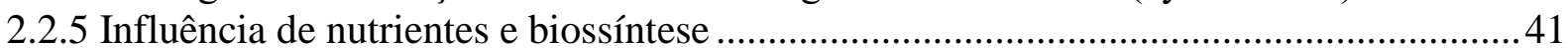

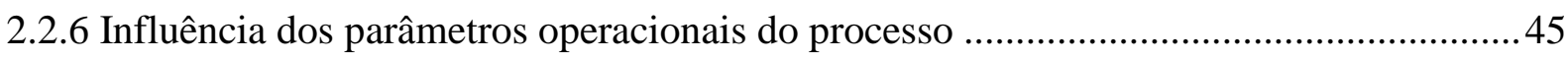

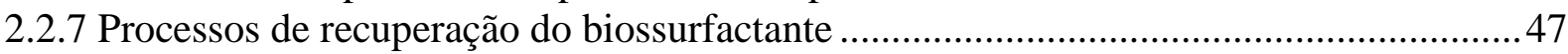

2.3 Processos fermentativos de produção dos biossurfactantes ........................................49

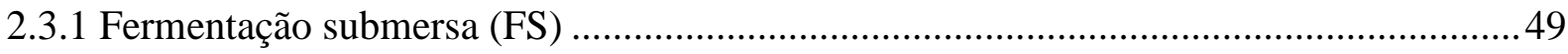

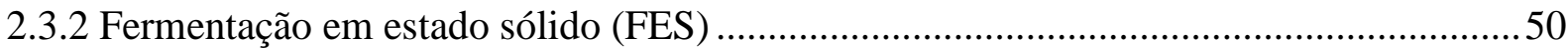

2.4 Utilização de resíduos agroindustriais para a produção de biossurfactantes .............52

2.4.1 Bagaço de cana-de-açúcar e agentes indutores...............................................................54

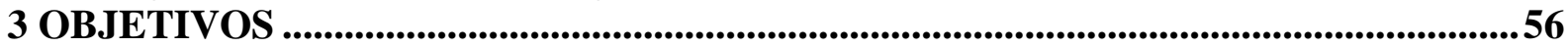

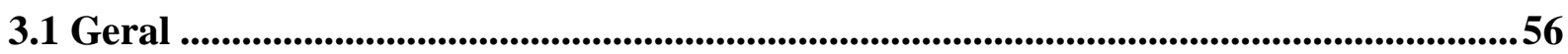

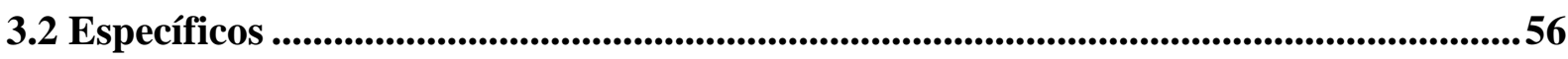

4 MATERIAL E MÉTODOS ........................................................................................57

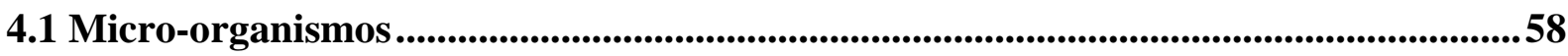

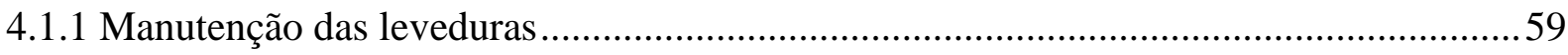

4.2 Identificação das leveduras produtoras de biossurfactantes ....................................59

4.2.1 Reativação das leveduras e fermentação submersa ......................................................59

4.2.2 Testes de identificação da produção de biossurfactantes ...............................................60

4.3 Seleção da levedura com maior potencial para produção de biossurfactantes por

fermentação em estado sólido (FES) ................................................................................60

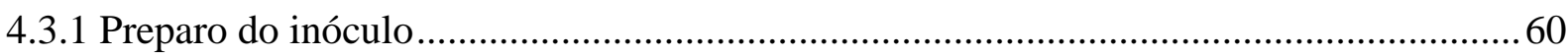

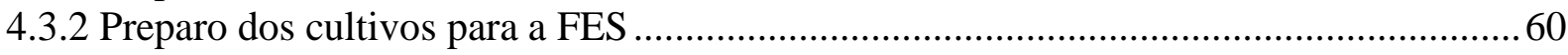

4.3.3 Extração e análise da produção de biossurfactante .......................................................61

4.4 Avaliação da produção de enzimas lignocelulolíticas pela levedura selecionada para a produção de biossurfactante por FES .....................................................................62

4.5 Estudo de condições para o processo de produção de biossurfactantes pela levedura selecionada.

4.5.1 Avaliação da influência de diferentes fontes de carbono para a produção de

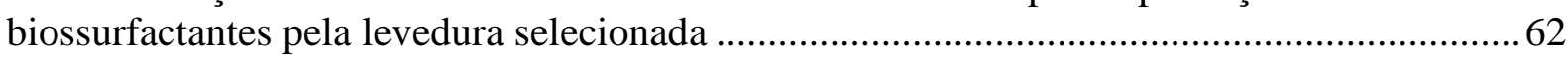

4.5.2. Avaliação do uso de indutores na produção de biossurfactantes pela levedura selecionada.

4.5.3. Estudo da influência da concentração da fonte de carbono e da aeração na produção de biossurfactantes pela levedura selecionada em fermentação submersa...... 
4.6. Avaliação da correlação entre tensoatividade e concentração do biossurfactante ... 67

4.7. Estudo das variáveis para a produção de biossurfactantes pela levedura selecionada em processo de fermentação em estado sólido.

4.7.1 Influência das variáveis tamanho médio das partículas do bagaço de cana-de-açúcar, volume de meio inicial, concentração celular e volume de água para extração

4.8 Comparação da produção de biossurfactantes em processo de fermentação submersa e fermentação em estado sólido pela levedura selecionada e avaliação da metodologia de extração 68

4.9 Caracterização bioquímica da molécula de biossurfactante produzida pela levedura selecionada

4.10 Avaliação da atividade tensoativa do biossurfactante produzido em relação à surfactantes sintéticos 69

4.11 Avaliação da utilização do biossurfactante em processo de biorremediação 69

4.12 Métodos analíticos 70

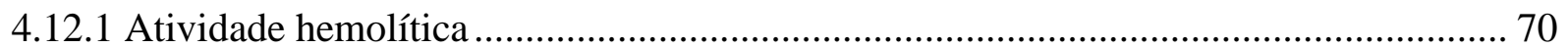

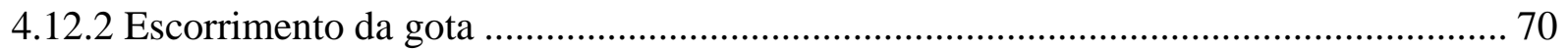

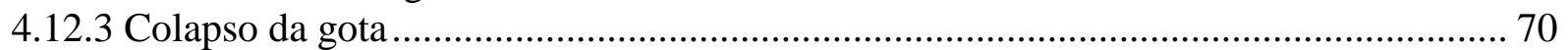

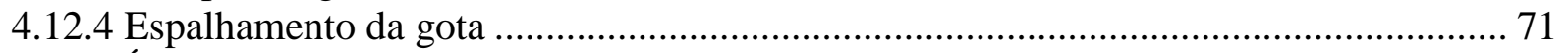

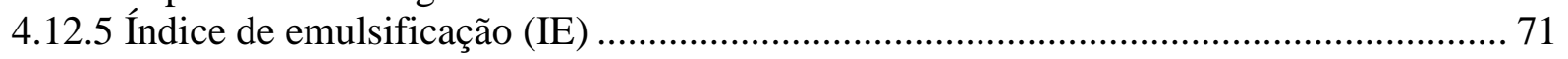

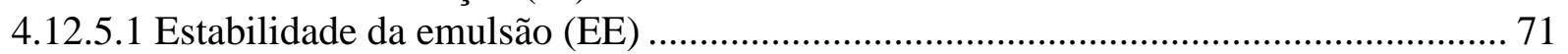

4.12.6 Determinação da concentração celular em câmara Agasse-Lafont-R e estimativa da

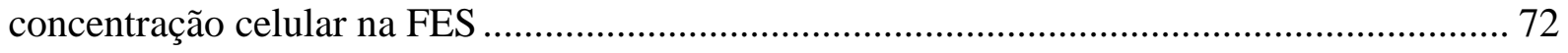

4.12.7 Caracterização do bagaço de cana-de-açúcar utilizado na FES ..................................... 73

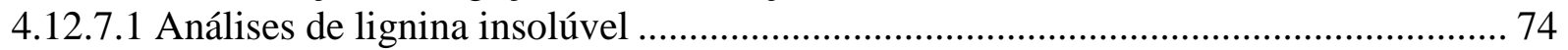

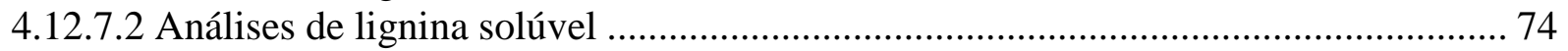

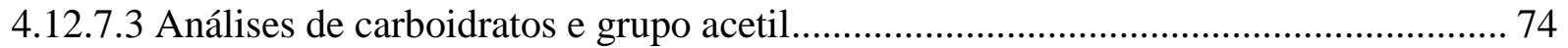

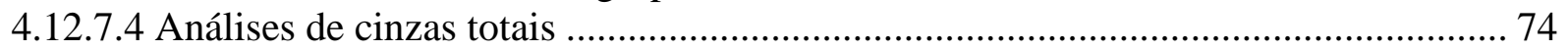

4.12.8 Determinação dos açúcares solúveis residuais do bagaço de cana-de-açúcar .............. 75

4.12.9 Determinação da capacidade absortiva do bagaço de cana-de-açúcar.......................... 76

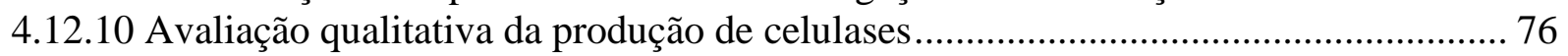

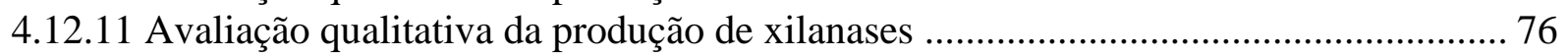

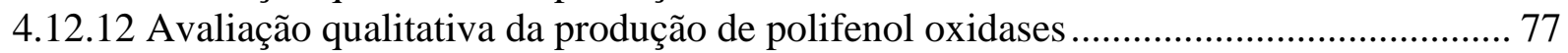

4.12.13 Avaliação da atividade de celulases totais (FPA) na fermentação em estado sólido.. 77

4.12.14 Avaliação da atividade de xilanases na fermentação em estado sólido ...................... 78

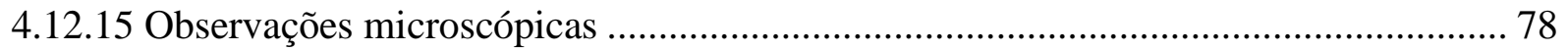

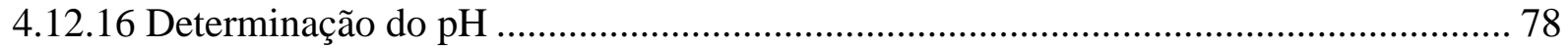

4.12.17 Determinação das concentrações de glicose, arabinose, frutose e manose.................. 79

4.12.18 Determinação da concentração do biossurfactante produzido................................... 79

4.12.19 Extração com solvente do biossurfactante na fermentação submersa ........................ 80

4.12.20 Extração do biossurfactante produzido por fermentação em estado sólido ................. 80

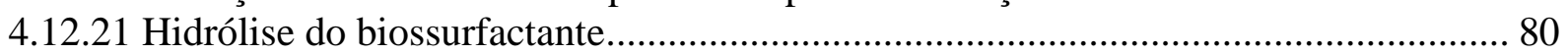

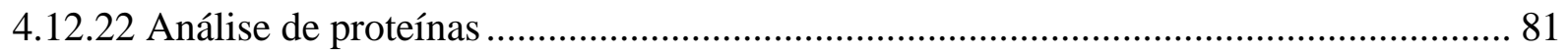

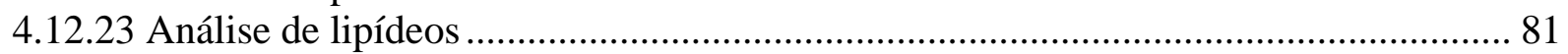

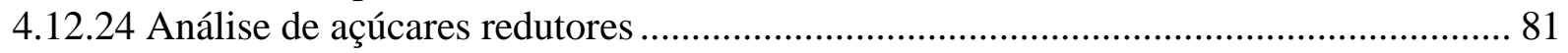


4.12.25 Análise de açúcares e polióis por cromatografia líquida de alta eficiência (HPLC) ...82

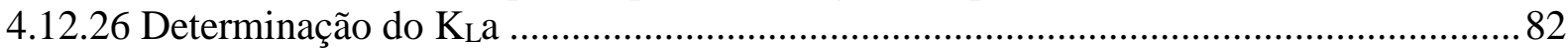

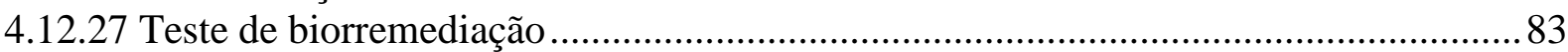

5 RESULTADOS E DISCUSSÃO ….................................................................................8 84

5.1 Identificação das leveduras produtoras de biossurfactantes..........................................84

5.2 Seleção da levedura com maior potencial para a produção de biossurfactante na FES

5.3 Características da levedura e do bagaço de cana-de-açúcar utilizados para a

fermentação em estado sólido (FES) ......................................................................................93

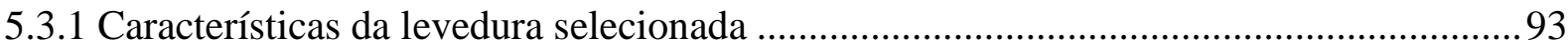

5.3.2 Caracterização do bagaço de cana-de-açúcar ................................................................ 94

5.4 Estudo exploratório da FES utilizando Aureobasidium pullulans LB 83 ....................96

5.5 Avaliação da utilização do bagaço de cana-de-açúcar como fonte de carbono na FES pela levedura Aureobasidium pullulans LB 83 ........................................................................100

5.5.1 Avaliação das atividades celulolítica e xilanolítica na FES ........................................ 102

5.6 Estudo das condições importantes para o processo de produção de biossurfactante

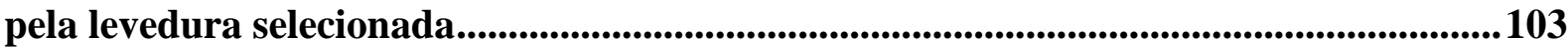

5.6.1 Avaliação de diferentes fontes de carbono .................................................................. 103

5.6.2 Avaliação do uso de indutores na produção de biossurfactantes por Aureobasidium

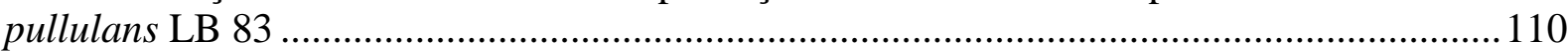

5.6.3 Influência da aeração e concentração de sacarose na produção de biossurfactantes por

Aureobasidium pullulans LB 83 em fermentação submersa ..............................................115

5.7 Avaliação da correlação entre a atividade tensoativa no teste de espalhamento da

gota e concentração do biossurfactante

5.8 Estudo das variáveis importantes para a produção de biossurfactante pela levedura selecionada em processo de fermentação em estado sólido.

5.9 Comparação de rendimento entre os processos de fermentação submersa e

fermentação em estado sólido para a produção de biossurfactante por A. pullulans LB

83 e avaliação do processo de extração ....................................................................................133

5.10 Extração e caracterização bioquímica do biossurfactante ............................................135

5.11 Avaliação da atividade tensoativa do biossurfactante produzido em relação à surfactantes sintéticos comerciais

5.12 Avaliação do potencial da utilização do biossurfactante produzido por

Aureobasidium pullulans LB 83 em processo de biorremediação ......................................138

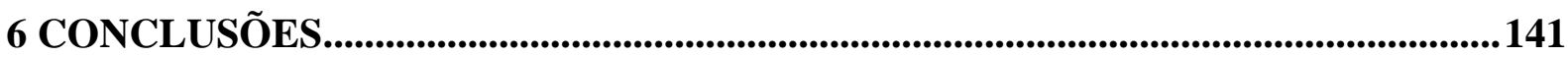

7 PERSPECTIVAS PARA TRABALHOS FUTUROS ...................................................142

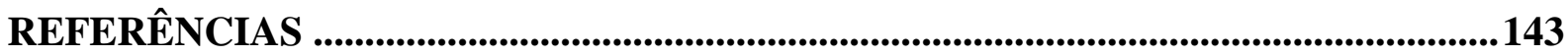





\section{INTRODUÇÃO E JUSTIFICATIVAS}

Surfactantes são moléculas de ampla aplicação industrial que possuem estrutura anfifílica, ou seja, uma parte polar e outra apolar. Esta característica estrutural garante sua propriedade de redução da tensão superficial e interfacial, tornando-os agentes de detergência (tensoativos), emulsificação, espumantes, umidificantes, agentes de suspensão e amaciamento. Essas moléculas são extensamente utilizadas em formulações cosméticas, farmacêuticas, produtos de limpeza, agroindustriais, em alimentos, na indústria petroquímica, na indústria têxtil, entre outras. O mercado global de surfactantes é grande e encontra-se em expansão, devendo chegar a aproximadamente a U\$ 39,86 bilhões em 2021, apresentando uma taxa de crescimento anual de 5,4\% entre 2016 e 2021 (MARKETS AND MARKETS, 2017).

A maioria dos surfactantes utilizados atualmente é sintético, sendo muitos deles derivados do petróleo. Entretanto, há uma procura cada vez maior por matérias-primas e processos alternativos que minimizem os impactos ambientais e estejam de acordo com as novas legislações de controle do meio ambiente. Neste contexto, a busca por processos biotecnológicos que utilizam fontes renováveis, como os resíduos agroindustriais, para a geração de produtos com alto valor agregado vem ganhando destaque por contribuírem para um desenvolvimento sustentável em relação aos processos tradicionais.

Nos últimos anos, os surfactantes biológicos, chamados biossurfactantes, têm despertado a atenção pela sua baixa toxicidade, biodegradabilidade, alta aceitabilidade ecológica e por poderem ser produzido a partir de fontes renováveis. Essas moléculas são produzidas principalmente por micro-organismos e podem ser classificados bioquimicamente como glicolipídeos, poilióis lipídeos, lipopeptídeos ou lipoproteínas, lipídeos neutros, ácidos graxos, fosfolipídeos, surfactantes poliméricos e biossurfactantes particulados. O tipo e a quantidade de biossurfactante produzido dependem da espécie de micro-organismo utilizada e dos parâmetros do processo de produção. A classificação estrutural do biossurfactante é importante pois está relacionada à aplicação, sendo que alguns apresentam maior atividade tensoativa (redução da tensão superficial e interfacial) enquanto outros apresentam maior atividade emulsionante. Porém, além da sua estrutura e propriedade, a patogenicidade do microorganismo produtor e seu grau de pureza também são determinantes para sua aplicação.

Apesar de apresentarem muitas vantagens, a produção destes compostos ainda é limitada, devido ao baixo rendimento de produção dos biossurfactantes em comparação aos surfactantes sintéticos, necessitando assim de estudos que reforcem a sua obtenção por vias 
alternativas com maior rendimento e menor custo. Desta forma, a busca por novos microorganismos produtores, matérias-primas de baixo custo e novos processos de produção são alternativas que devem ser exploradas.

A maioria dos registros encontrados na literatura sobre a produção de biossurfactantes refere-se a processos envolvendo bactérias. Entretanto, alguns biossurfactantes de origem bacteriana não são adequados para utilização na indústria alimentícia, farmacêutica e cosmética, devido à possível natureza patogênica. Por isso, recentemente, a utilização de leveduras para a produção de biossurfactantes também vem sendo explorada.

O Brasil apresenta uma invejável biodiversidade ainda muito pouco conhecida e a busca e seleção de novas leveduras produtoras de biossurfactantes representa uma importante estratégia biotecnológica. A produção de biossurfatante por leveduras possui vantagens por muitas não apresentarem patogenicidade e algumas apresentarem o status GRAS (Generally Regarded as Safe), o que garante a sua inocuidade.

Atualmente, os estudos de produção de biossurfactantes vêm sendo conduzidos principalmente em processos de fermentação submersa. No entanto, esta estratégia enfrenta um problema severo quando utilizada em reatores pilotos ou de larga escala para produção de tensoativos. Os processos são conduzidos com agitação e aeração forçada, de forma que, no início do processo de produção do biossurfactante, grandes quantidades de espuma são formadas. Assim, a fermentação fica altamente prejudicada pela perda de biomassa, nutrientes e produtos contidos na espuma, diminuindo os índices de produção ou inviabilizando o processo.

Pouco foi estudado sobre a produção de biossurfactantes em fermentação em estado sólido (FES) e os registros encontrados na literatura referem-se à produção de biossurfactante por bactérias ou fungos filamentosos. O processo de FES tem o potencial de aumentar a viabilidade da produção de biossurfactantes, pois é uma alternativa para se evitar a formação de espuma, fator limitante da obtenção desses compostos por fermentação submersa. Porém, conforme a literatura consultada, não existem relatos sobre a produção de biossurfactantes por leveduras utilizando o processo de fermentação em estado sólido, o que destaca a novidade do presente trabalho.

De um modo geral, o ambiente fornecido ao micro-organismo na FES é bem diferente daquele fornecido pela fermentação submersa. A disponibilidade restrita de água pode estimular a produção e excreção de alguns metabólitos específicos, que não seriam produzidos na fermentação submersa, além de possibilitar, em alguns casos, uma maior produtividade volumétrica e um maior rendimento em relação à fermentação submersa. 
Os substratos tipicamente utilizados na FES são de origem agroindustrial, subprodutos ou produtos agrícolas propriamente ditos, processados ou não. No Brasil, o agronegócio apresenta grande importância no processo de desenvolvimento e o incremento de novas tecnologias empregadas no setor agrícola desencadeou um aumento na obtenção de produtos e, consequentemente, geração de subprodutos. O cultivo da cana-de-açúcar, por exemplo, merece destaque, sendo a produção brasileira a maior do mundo (COMPANHIA NACIONAL DE ABASTECIMENTO, 2017). O bagaço de cana-de-açúcar é o subproduto disponível em maior quantidade pelas indústrias sucro-alcoleiras. Grande parte desta biomassa (60 a 90\%) é utilizada como combustível para geração de energia pela própria indústria, entretanto, o excedente de bagaço de cana-de-açúcar gera problemas ambientais e de estocagem.

Consequentemente, a utilização do bagaço da cana-de-açúcar (uma fonte de material lignocelulósico abundante) é uma alternativa importante para a utilização em processos biotecnológicos visando à geração de produtos com alto valor agregado, como por exemplo, os biossurfactantes.

Neste contexto, este trabalho visando a produção de biossurfactantes por leveduras em processo de FES utilizando o bagaço de cana-de-açúcar como substrato, por sua característica inovadora, vai de encontro aos conceitos de biorrefinaria e sustentabilidade. Essa abordagem evita o problema da formação de espuma e apresenta-se como uma tecnologia alternativa, que busca por um produto e um processo que gerem menores impactos ambientais (com menor gasto de energia, menor formação de poluentes e maior biodegradabilidade), características essas que garantem a promoção do desenvolvimento sustentável. 


\section{REVISÃO BIBLIOGRÁFICA}

\subsection{Surfactantes}

A palavra surfactante vem da contração de surface-active-agent e se refere à substância que tem a propriedade de se distribuir na superfície ou interfaces fluidas com diferentes graus de polaridade (ar-líquido, líquido-líquido ou sólido-líquido) e alterar a energia livre nessa superfície ou interface, sendo capazes de reduzir a tensão superficial e interfacial (MULLIGAN, 2005; ROSEN; KUNJAPPU, 2012).

Essa propriedade é consequência da estrutura destas moléculas, compostas por uma porção hidrofílica e outra hidrofóbica, ou seja, são moléculas anfipáticas. Esta diferença de energia de interação entre as partes da molécula de surfactante que causa a sua acumulação na interface das fases, de forma que a parte hidrofóbica da molécula fique voltada para a fase mais apolar do sistema, enquanto a porção hidrofílica está orientada para a fase polar. Dependendo da sua concentração no meio, as moléculas de surfactante podem se organizar na forma de micelas levando à emulsificação de dois líquidos imiscíveis (Figura 1) (MULLIGAN, 2005; MILNE et al., 2015).

Figura 1 - Estrutura dos surfactantes e sua distribuição entre as interfaces água/óleo e óleo/água, formando emulsão

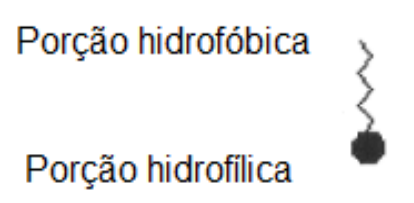

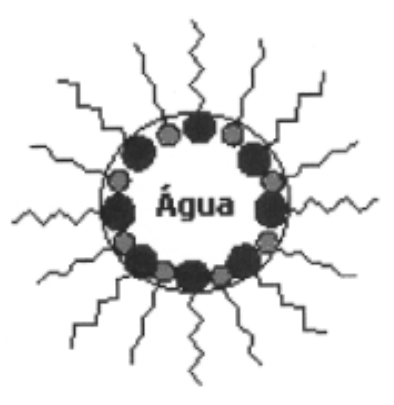

Emulsão água/óleo

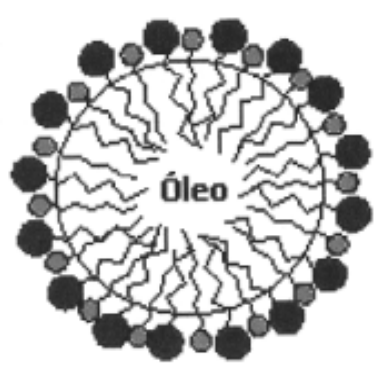

Emulsão óleo/água

Fonte: Adaptado (OLIVEIRA et al., 2004).

A formação de um filme molecular ordenado nas interfaces é responsável pelas propriedades únicas dos surfactantes, como: detergência, emulsificação (micro e macro), lubrificação, ação espumante e antiespumante, capacidade molhante, solubilização, suspensão 
e dispersão de fases (LIN, 1996; NITSCHKE; PASTORE, 2002). Por isso, os surfactantes são uns dos mais versáteis compostos da indústria química, estando presentes em diversos produtos como medicamentos, cosméticos, alimentos, combustíveis aditivados, produtos de limpeza, produtos agrícolas, entre outros. Além da sua importância em diversos processos como síntese de polímeros, prospecção de petróleo, flotação e beneficiamento de minérios (ROSEN; KUNJAPPU, 2012).

Os surfactantes sintéticos estão disponíveis em várias formas e geralmente são classificados de acordo com a sua carga atômica como catiônicos, aniônicos não iônicos ou anfóteros (SCHMITT, 2001). São produzidos por métodos químicos orgânicos, dependendo do tipo e da estrutura desejada, e a maioria é derivada de petróleo, (DESAI; DESAI, 1993; NITSCHKE; PASTORE, 2002). Os surfactantes químicos mais amplamente utilizados são sulfatos ou sulfonatos de alquila com cadeias lineares ou ramificadas (MARCHANT; BANAT, 2012). O tipo, a localização e a quantidade das ramificações, assim como a solubilidade em água são características importantes quando se considera a biodegradabilidade da molécula de surfactante (KRONBERG; HOLMBERG; LINDMAN, 2014).

As atividades tensoativa e emulsificante podem ser medidas pelos parâmetros de tensão superficial, tensão interfacial, concentração micelar crítica $\left(\mathrm{CMC}^{*}\right)$ e balanço hidrofílicolipofílico (BHL) (CHRISTOFI e IVSHINA, 2002).

A tensão superficial e a tensão interfacial são explicadas como o desequilíbrio entre as forças agindo sobre as moléculas da superfície (tensão superficial) ou entre duas fases de uma mistura (tensão interfacial), em relação àquelas que estão no interior do líquido. Isso ocorre porque as moléculas localizadas na interfase líquido-ar ou líquido-líquido realizam um número menor de interações intermoleculares. Esse fenômeno leva à formação de uma força resultante que atrai as moléculas da superfície ou da interfase para o interior do líquido (Figura 2A). Devido à essa força de coesão, a área superficial do líquido tende a diminuir, e por isso as gotas adotam formatos esféricos e é possível o efeito de capilaridade (Figura 2B). A atividade tensoativa dos surfactantes ocorre devido à presença do grupo lipofílico da molécula, que faz com que as moléculas de surfactante ocupem preferencialmente a superfície ou interfase do líquido, diminuído a força de coesão entre as moléculas dessa camada, levando à redução da tensão superficial ou interfacial. Porém, após saturar a superfície dos líquidos, a adição de surfactante tem pouco efeito sobre a tensão superficial ou interfacial, principalmente após atingir a CMC* (ADAMSON; GAST, 1997). 
Figura 2 - Esquema das forças intermoleculares no interior e na superfíciedo líquido (A) e formato esférico da gota (B), resultado da força de coesão das moléculas da superfície

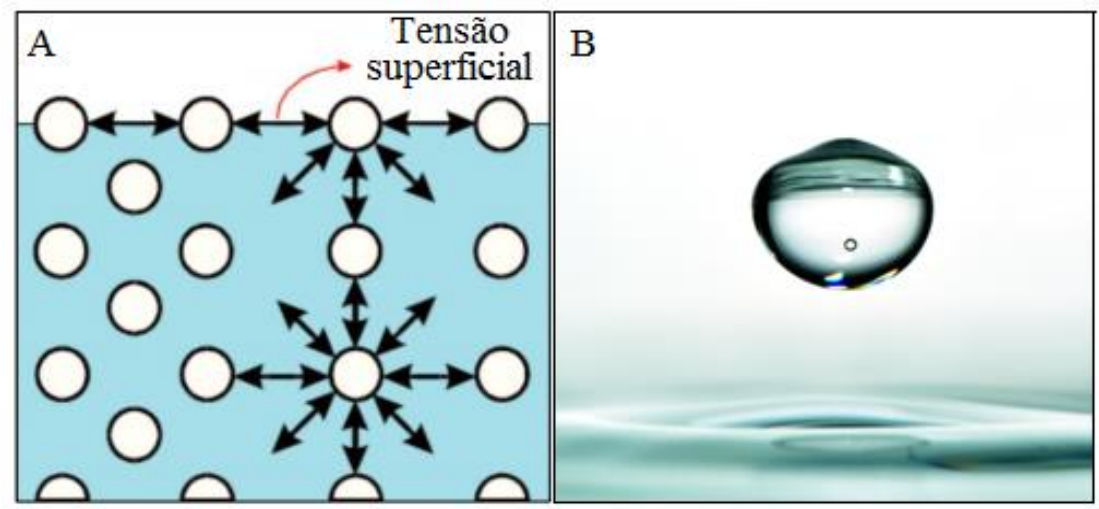

Fonte: Adaptado (PIRÔLLO, 2006).

A CMC* é definida como a mínima concentração de surfactante a partir da qual se inicia a formação de micelas, que conferirá as propriedades de emulsificação, detergência e solubilização de compostos hidrofóbicos (Figura 3). Esta concentração varia dependendo do surfactante, principalmente do tamanho do grupo lipofílico, e das condições experimentais (como força iônica e temperatura). Em concentrações acima da CMC*, o surfactante aumenta a solubilidade de compostos orgânicos com baixa solubilidade em água, sendo o composto incorporado no interior da micela; contudo, as tensões superficial e interfacial da solução permanecem quase constantes. Abaixo desta concentração o surfactante se distribui na superfície ou interface do líquido, o que leva a uma diminuição da tensão superficial ou interfacial. Esta diminuição ocorre exponencialmente com o aumento da concentração de surfactante até atingir a CMC* (CHRISTOFI; IVSHINA, 2002).

Figura 3 - Diagrama esquemático da variação da tensão superficial, interfacial e solubilidade de compostos orgânicos com a concentração de tensoativos

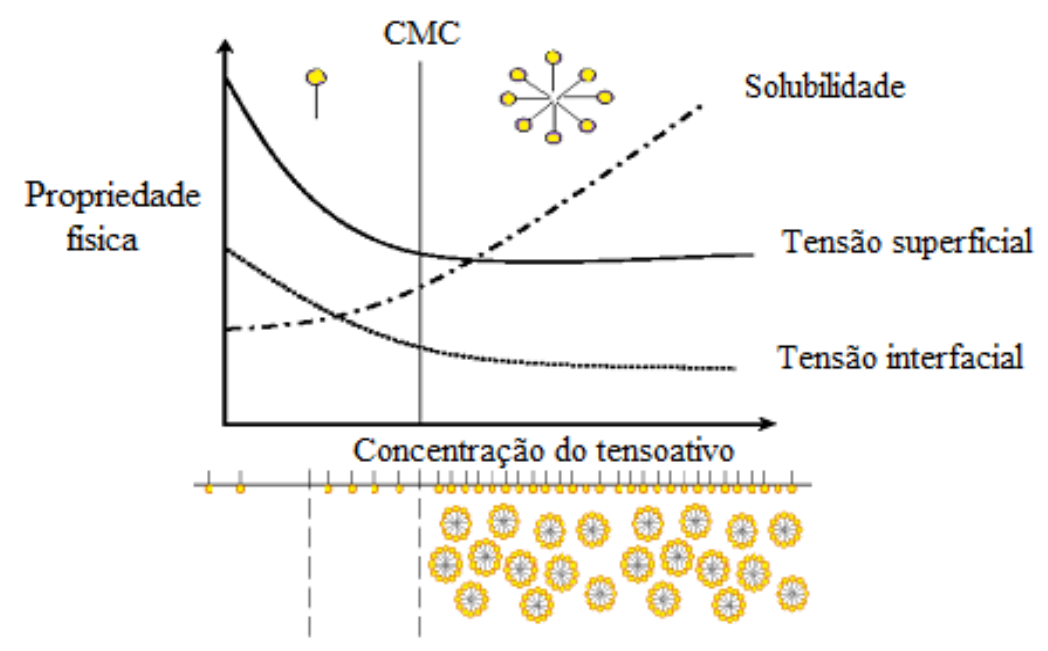

Fonte: Adaptado de CAMILIOS NETO, 2010 
Emulsões são definidas como a mistura íntima de dois líquidos imiscíveis, um dos quais está disperso no outro na fórma de glóbulos. Portanto, são sistemas heterogênios termodinamicamente instáveis. De acordo com a hidrofilia ou lipofilia da fase dispersante, esses sistemas classificam-se em óleo em água (O/A) ou água em óleo (A/O) e são compostas por três fases: aquosa, oleosa e emulsificante (MORRISON; ROSS; 2002). Os surfactantes se adsorvem na interface entre a fase dispersa e dispersante durante o processo de emulsificação, estabilizando cineticamente o sistema e prevenindo fenômenos de instabilidade e, consequentemente de separação de fases (HOLMBERG et al., 2002; MORRISON; ROSS; 2002). As emulsões são amplamente empregadas como veículos nas indústrias cosmética, farmacêutica e alimentícia, principalmente como sistemas que permitem o transporte de ativos ou fármacos lipofílicos e hidrofílicos em uma mesma formulação e pela possibilidade de se controlar características sensoriais e organolépticas (ATTWOD; FLORENÇA, 1987). Entretanto, a propriedade emulsionante dos surfactantes está relacionada com os tamanhos das porções hidrofóbicas e hidrofílias das moléculas, e, por isso, nem todos os surfactantes apresentam propriedade emulsionante (HOLMBERG et al., 2002).

O BHL é uma classificação utilizada para surfactantes não iônicos de acordo com a atração relativa simultânea de um emulsificante para as duas fases de um sistema de líquidos imiscíveis (ex: óleo/água) (ATTWOOD; FLORENÇA, 1987). Essa propriedade é representada por uma escala arbitrária de 0-20, no qual as moléculas mais hidrofílicas possuem maiores números. Com o BHL podemos prever o tipo de emulsão formada pelo surfactante (água em óleo ou óleo em água) por comparação com surfactantes de BHL conhecidos. Surfactantes com valores de BHL menores que seis favorecem a estabilização de emulsões do tipo água em óleo, enquanto surfactantes com valores de BHL entre 10 a 18 possuem o efeito oposto e favorecem a formação de emulsões do tipo óleo em água (GRIFFIN, 1949; SATPUTE et al, 2010).

A relevância econômica dos surfactantes é demonstrada pelos dados do seu mercado global, que se encontra em expansão e deve chegar a aproximadamente a U\$ 39,86 bilhões em 2021, apresentando uma taxa de crescimento anual de 5,4\% entre 2016 e 2021 (MARKETS AND MARKETS, 2017). Estes dados reafirmam a importância dessas moléculas, que são essenciais em diferentes setores industriais.

Historicamente, os surfactantes sintéticos são empregados em processos indústriais há mais de 100 anos, sendo o primeiro surfactante sintético sintetizado em 1890, a partir de pequenas cadeias hidrofóbicas ligadas ao álcool. A observação de que essas moléculas eram capazes de formar espuma e remover gorduras foi feita pelo alemão A. Kraft, e em menos de 
20 anos essas moléculas já passaram a fazer parte de formulação de sabões e detergentes (BORSATO; MOREIRA; GALÃO, 2004). Porém o uso industrial e doméstico indiscriminado dessas substâncias trouxe consequências ambientais devido à sua baixa biodegradabilidade e consequente acumulação em águas pluviais ou em corpos receptores de água, como córregos, rios e lagoas. A presença dessas substâncias nestes ambientes leva à problemas severos de eutrofização e toxicidade aquática (ROMANELLI, 2004). Assim, propostas de substituição destes compostos sintéticos por substâncias mais aceitáveis ecologicamente são requeridas e merecem destaque no cenário atual.

\subsection{Biossurfactantes}

\subsubsection{Definição e vantagens}

Os biossurfactantes constituem um grupo bastante diverso de compostos tensoativos sintetizados principalmente, mas não exclusivamente por micro-organismos (NITSCHKE; PASTORE, 2002). Existem também os surfactantes naturais, extraídos de vegetais e animais, como exemplo das saponinas, além dos chamados biossurfactantes semi-sintéticos ou modificados, obtidos por transformações enzimáticas de uma molécula precursora de biossurfactante, afim de modificar a sua estrutura, propriedade físico-química e biológica (ALBANO et al., 2014; DELBEKE et al., 2015).

Apesar dos biossurfactantes microbianos terem sido relatados pela primeira vez em 1949, por Jarvis e Johnson em trabalhos com Pseudomonas aeruginosa, esses compostos ganharam maior projeção na sociedade no final da década de 1990, sendo utilizados em processos de biorremediação (NITSCHKE; PASTORE, 2002; DESAI; BANAT, 1997).

Esses compostos têm despertado interesse cada vez maior como possível substituinte dos surfactantes sintéticos e por apresentarem muitas aplicações potenciais, principalmente industriais e ambientais (BANAT et al., 2000; SATPUTE et al., 2010; VIJAYAKUMAR; SARAVANAN, 2015). Além disso, atualmente há uma procura cada vez maior por produtos alternativos que minimizem os impactos ambientais e estejam de acordo com as novas legislações do controle do meio ambiente (BUENO; SILVA; GARCIA-CRUZ, 2010).

Neste contexto, os biossurfactantes, apresentam-se como alternativas vantajosas frente aos surfactantes químicos por apresentarem alta biodegradabilidade (são facilmente degradados na natureza por micro-organismos), baixa toxicidade e grande disponibilidade de matériasprimas para sua produção. De fato, os biossurfactantes podem ser produzidos a partir de 
matérias-primas renováveis, de baixo custo e que estão disponíveis em grandes quantidades, como resíduos agroindustriais ricos em carboidratos e/ou hidrocarbonetos (MAKKAR; CAMEOTRA, 2002; FRAKUDDIN, 2012).

Além disso, os surfactantes biológicos podem ser produzidos em condições mais amenas de temperatura e pressão e possuem vantagens como maior efetividade e resistência a variações físicas, pois toleram ampla faixa de temperatura, $\mathrm{pH}$ e força iônica quando comparados aos surfactantes produzidos por síntese química (MAKKAR; CAMEOTRA, 2002; SOUZA et al, 2014; LIANG et al., 2017). Também são mais eficientes, uma vez que apresentam menores CMC*s e maiores índices de emulsificação e apresentam boa atividade tensoativa (BANAT, 1995; MULLIGAN, 2009; PORNSUNTHORNTAWEE et al., 2008). Tais características de eficiência e eficácia são essenciais para aplicação dos surfactantes. A CMC* dos biossurfactantes varia de 1 a $2000 \mathrm{mg} / \mathrm{L}$, enquanto as tensões interfaciais (óleo/água) e superficiais são respectivamente aproximadamente 1 e $30 \mathrm{mN} / \mathrm{m}$. Os bons surfactantes são capazes de reduzir a tensão da superfície da água de 72 a 35 mN/m e a tensão interfacial do nhexadecano de 40 a $1 \mathrm{mN} / \mathrm{m}$ (SANTOS et al., 2016). Adicionalmente, muitos deles podem ser utilizados em produtos farmacêuticos, cosméticos e aditivos alimentares funcionais por apresentarem biocompatibilidade e digestibilidade (KOSARIC, 2001).

Apesar de muito vantajosos ainda não são capazes de competir economicamente com os surfactantes químicos no mercado, principalmente pelo seu custo elevado (PRUTHI; CAMEOTRA, 1997; SANTOS et al., 2017). Este alto custo é consequência do uso de substratos caros, de metodologias ineficientes no bioprocessamento e da baixa produtividade das estirpes microbianas. Essa situação vem reforçar a necessidade de novas estratégias de viabilização de sua produção por via biotecnológica (DE et al., 2015).

As estratégias para a redução do custo de produção dos biossurfactantes se baseiam principalmente nos micro-organismos (seleção de novos micro-organismo, adaptação ou engenharia genética para aumentar a produção), no processo (utilização de novos processos, projetos e engenharia para redução do capital de implantação e custo de operação), no substrato de crescimento microbiano ou matéria-prima utilizada (escolha de substratos de baixo custo e amplamente disponível) e aproveitamento de co-produtos e subprodutos do processo (minimizados ou processados para que sejam reaproveitados ao invés de tratados e descartados como resíduos) (MULLIGAN; GIBBS, 1993; MONTEIRO et al, 2010; SANTOS et al.; 2017).

Um reflexo do crescimento da importância industrial dos biossurfactantes são os dados apresentados pela Global Market Insights (2016) que apontam o crescimento anual médio de 
4,2 \% ao ano do mercado destas biomoléculas. Em 2015 foram arrecadados 1,7 bilhões de dólares, com uma produção de 370.500 toneladas, e, em 2018, espera-se uma produção 476.500 toneladas e uma arrecadação de 2,2 bilhões de dólares. Para 2023 espera-se que o mercado global de biossurfactantes atinja 2,7 bilhões de dólares.

\subsubsection{Classificação estrutural e aplicações}

É comum na literatura os biossurfactantes serem classificados quanto à sua carga, a natureza bioquímica de seu grupamento polar, origem microbiana e peso molecular. Com relação à carga, os biossurfactantes mais comuns são neutros ou aniônicos, variando desde ácidos graxos pequenos a grandes polímeros. Até o momento, não existem relatos de biossurfactantes com grupos polares positivos, entretanto, em certos casos a presença de grupos nitrogenados confere ao biossurfactante um grau de característica catiônica a parte da molécula (CAMPOS, 2013). A porção hidrofóbica da molécula é composta por ácidos graxos de cadeia longa e a porção hidrofílica pode ser composta por carboidratos, peptídeos cíclicos, aminoácidos, ácidos carboxílicos fosfatados ou álcoois. A massa molar dos biossurfactantes normalmente varia entre 500 a 15000 Da (BOGNOLO, 1999).

$\mathrm{Na}$ classificação bioquímica dos biossurfactantes, os principais tipos relatados na literatura são os glicolipídeos, lipopeptídeos ou lipoproteínas, lipídeos neutros, ácidos graxos e fosfolipídeos, surfactantes poliméricos e biossurfactantes particulados (DESAI; DESAI, 1993; DESAI; BANAT, 1997; NITSCHKE; PASTORE, 2002). Os principais representantes de cada classe e a característica do grupamento polar de cada classe de biossurfactantes estão apresentados na Tabela 1. Os grupamentos polares se ligam a uma ou mais cadeias longas de ácidos graxos hidroxilados ou não, que proporciona um carácter apolar a molécula.

Uma classe ainda pouco estudada dentre as classes de biossurfactantes, mas que apresenta grande potencial corresponde aos polióis lipídeos. Surfactantes sintéticos caracterizados estruturalmente como ésteres de polióis já são conhecidos há muito tempo e amplamente utilizados, principalmente os alcanoatos de sorbitano (comercialmente conhecido como Span) e seu etoxilado (comercialmente conhecido como Tween). Ésteres de glicerol também são bastante conhecidos e quimicamente sintetizados (KRONBERG et al., 2014). Entretanto, apesar de terem sido reportadas desde a década de 40 (YABUTA et a., 1941; STODOLA et al., 1967), somente nas últimas décadas biomoléculas excretadas por microorganismos, que possuem essa estrutura começaram a ter suas aplicações como biossurfactantes exploradas. Uma nova biomolécula com estrutura de poliól lipídeo foi descrita por Kurosawa 
(1994) e chamada de Liamocin ou heavy oil, produzida por Aureobasidum pullulans. Este biossurfactante possui em sua parte polar os polióis manitol ou arabitol (MANITCHOTPISIT et al, 2011; PRICE et al, 2013). A parte apolar da molécula (lipídica) tem sua estrutura semelhante ao lipídeo Exophilin, excretado por Exophiala psiciphilia, que possui comprovada atividade antimicrobiana (DOSHIDA et al, 1996). Por isso, estudos recentes demonstram importantes aplicações da molécula de Liamocin na área da saúde, como sua atividade antimicrobiana e anticâncer (ISODA; NAKAHARA, 1997; PRICE et al., 2013; MANITCHOTPISIT et al, 2014).

Tabela 1 - Classes de biossurfactantes, característica de cada grupamento hidrofílico e seus principais representantes

\begin{tabular}{|c|c|c|c|}
\hline $\begin{array}{c}\text { Classe de } \\
\text { biossurfactante }\end{array}$ & $\begin{array}{c}\text { Característica do } \\
\text { grupamento hidrofílico }\end{array}$ & Representantes & Referência \\
\hline \multirow[t]{8}{*}{ Glicolipídeos } & Carboidratos & Ramnolipídeos & HISATSUKA et al. (1971) \\
\hline & (monossacarídeos, & Trealoselipídeos & RAPP et al. (1979) \\
\hline & dissacarídeos, & Celobiolipídeos & SYLDATK et al. (1985) \\
\hline & trissacarídeos ou & Soforolipídeos & HOMMEL et al. (1987) \\
\hline & oligossacarídeos), alguns & Manosil eritritol & KITAMOTO et al. (1993) \\
\hline & apresentam anéis & lipídeos & LUNA (2010) \\
\hline & lactônicos & Lunasan & SARAVANAKUMARI e \\
\hline & & Xilolipídeos & MANI (2010) \\
\hline \multirow[t]{3}{*}{ Poliol lipídeos } & Polióis de 5 ou 6 & Poliol ésteres de & STODOLA et al. (1967) \\
\hline & carbonos, sendo os mais & ácidos graxos & GARAY et al. (2017) \\
\hline & comuns arabitol e manitol & Liamocin & $\begin{array}{l}\text { KUROSAWAA et al. } \\
\qquad(1994)\end{array}$ \\
\hline \multirow{4}{*}{$\begin{array}{l}\text { Ácidos graxos, } \\
\text { lipídeos neutros } \\
\text { e fosfolipídeos }\end{array}$} & Grupo carboxilato, & Ácidos graxos & COOPER et al. (1989) \\
\hline & fosfato/hidroxi ligados ao & Lipídeos neutros & MACDONALD et al. \\
\hline & glicerol ou não & Fosfolipídeos & (1981) \\
\hline & & & KOCH et al. (1988) \\
\hline
\end{tabular}

Continua 
Conclusão

\begin{tabular}{|c|c|c|c|}
\hline $\begin{array}{c}\text { Classe de } \\
\text { biossurfactante }\end{array}$ & $\begin{array}{c}\text { Característica do } \\
\text { grupamento hidrofílico }\end{array}$ & Representantes & Referência \\
\hline \multirow{8}{*}{$\begin{array}{l}\text { Lipopeptídeos e } \\
\text { lipoproteínas }\end{array}$} & \multirow{8}{*}{$\begin{array}{c}\text { Peptídeos ou proteínas, } \\
\text { alguns deles apresentam } \\
\text { estrutura cíclica }\end{array}$} & Peptídio-lipídio & JAVAHERI et al. (1985) \\
\hline & & Viscosin & NEU e PORALLA (1990) \\
\hline & & Serrawetin & MATSUYAMA et al. \\
\hline & & Surfactin & (1991) \\
\hline & & Subtilisin & ARIMA et al. (1968) \\
\hline & & Gramicidin & BERNHEIMER e \\
\hline & & Polimixina & AVIGAD (1970) \\
\hline & & & SUZUKI et al. (1965) \\
\hline \multirow{9}{*}{$\begin{array}{l}\text { Surfactantes } \\
\text { poliméricos }\end{array}$} & \multirow{9}{*}{$\begin{array}{c}\text { Polímeros como } \\
\text { heteropolissacarídeos, ou } \\
\text { uma mistura de } \\
\text { polissacarídeo e proteínas }\end{array}$} & Emulsan & ZOSIM et al. (1982) \\
\hline & & Biodispersan & ROSENBERG et a. (1988) \\
\hline & & Manana-lipídeo- & KAPPELI et al. (1984) \\
\hline & & proteína & CIRIGLIANO e CARMAN \\
\hline & & (ou Manoproteína) & (1984) \\
\hline & & Liposan & SINGH e DESAI (1989) \\
\hline & & Carboidrato- & RUFINO et al. (2011) \\
\hline & & proteína-lipídeo & \\
\hline & & Rufisan & \\
\hline \multirow[t]{6}{*}{ Particulados } & Vesículas e membranas & Vesículas & KAPPELI e FINNERTY \\
\hline & celulares que possuem & & (1979) \\
\hline & maior quantidade de & Células & ROSEMBERG (1986) \\
\hline & fosfolipídeos e & & \\
\hline & polissacarídeos formam & & \\
\hline & micro emulsões & & \\
\hline
\end{tabular}

Fonte: Arquivo pessoal.

A classificação estrutural do biossurfactante é importante, pois está relacionada com a sua ação e, consequentemente, aplicação. Compostos biossurfactantes de baixo peso molecular, como glicolipídeos, poliól lipídeos, ácidos graxos, lipídeos neutros e lipopeptídeos de cadeia curta, possuem maior atividade de redução da tensão superficial e interfacial, por isso também são chamados de biotensoativos. Compostos biossurfactantes de alto peso molecular, como os 
lipopolissacarídeos, lipoproteínas, poliméricos e particulados, são descritos como melhores agentes emulsificantes, por isso também são chamados de bioemulsificantes (SATPUTE et al., 2010; MONTEIRO et al., 2010; SMITH et al., 2010). As principais aplicações dos biossurfactantes estão apresentadas na Tabela 2.

Tabela 2 - Funções, tipos e aplicações de biossurfactantes atualmente utilizados

\begin{tabular}{|c|c|c|}
\hline Funções & Tipos (micro-organismo produtor) & Aplicações \\
\hline $\begin{array}{c}\text { Emulsificante e } \\
\text { Dispersante }\end{array}$ & Liposana (Candida lipolytica) & $\begin{array}{l}\text { Cosméticos, tintas, } \\
\text { óleos e alimentos }\end{array}$ \\
\hline Solubilizante & Lipopeptídeos (Pseudomonas aeruginosa) & $\begin{array}{c}\text { Medicamentos e } \\
\text { produtos de higiene }\end{array}$ \\
\hline Umectantes & $\begin{array}{c}\text { Complexo proteína-polissacarídeo-lipídeo } \\
\text { (Curvularia lunata) }\end{array}$ & $\begin{array}{l}\text { Medicamentos, } \\
\text { indústria têxtil e tintas }\end{array}$ \\
\hline $\begin{array}{c}\text { Agente } \\
\text { espumante }\end{array}$ & $\begin{array}{c}\text { Glicolipídeos (Torulopsis bombicola) } \\
\text { Manoproteínas (Saccharomyces cerevisiae) }\end{array}$ & $\begin{array}{l}\text { Produtos de higiene } \mathrm{e} \\
\text { cosméticos }\end{array}$ \\
\hline Espessante & $\begin{array}{l}\text { Rhamnolipídeos W.O. 2004/040984 } \\
\text { (patente) }\end{array}$ & Alimentos e tintas \\
\hline $\begin{array}{c}\text { Agente } \\
\text { sequestrador de } \\
\text { metais }\end{array}$ & $\begin{array}{c}\text { Rhaminolipídeos } \\
\text { (Pseudomonas aeruginosa), } \\
\text { Surfactina e Iturina (Bacillus subtilis), } \\
\text { Manosil eritritol lipídeo (Candida lipolytica) }\end{array}$ & Mineração \\
\hline $\begin{array}{c}\text { Atividade } \\
\text { antimicrobiana }\end{array}$ & $\begin{array}{c}\text { Rufisana (Candida lipolytica) } \\
\text { Lusana (Candida sphaerica) }\end{array}$ & $\begin{array}{l}\text { Controle biológico de } \\
\text { fitopatógenos }\end{array}$ \\
\hline Detergente & Glicolipídeos (Candida antártica) & Detergentes industriais \\
\hline Desemulsionante & Rhaminolipídeos (Pseudomonas aeruginosa) & $\begin{array}{l}\text { Tratamento de resíduos } \\
\text { e recuperação de óleos }\end{array}$ \\
\hline $\begin{array}{c}\text { Mobilização de } \\
\text { óleo }\end{array}$ & Soforolipídeos (Candida bombicola) & $\begin{array}{l}\text { Recuperação de } \\
\text { petróleo }\end{array}$ \\
\hline $\begin{array}{c}\text { Agente de } \\
\text { biorremediação }\end{array}$ & Rhaminolipídeos (Pseudomonas aeruginosa) & Restauração ambiental \\
\hline $\begin{array}{l}\text { Rompimento de } \\
\text { biofilmes }\end{array}$ & $\begin{array}{l}\text { Lipopeptídeos (Bacillus licheniformis } \\
\text { PCT/IB2009/055334) (patente) }\end{array}$ & Medicamentos \\
\hline
\end{tabular}

Fonte: Adaptado (CAMPOS et al, 2013). 
Os biossurfactantes possuem aplicações em uma variedade de processos industriais (detergentes, cosméticos, têxtil, tintas, alimentos e petroquímica), além de ambientais, na saúde, agricultura e mineração. E, devido à diversidade de estruturas e propriedade que estas moléculas podem apresentar é provável que novas aplicações para estas biomoléculas sejam descobertas. Porém, além da estrutura e propriedade, a patogenicidade do micro-organismo produtor e o seu grau de pureza são fatores importantes a serem considerados para a destinação de seu uso (ELSHIKH et al., 2017). Acredita-se, que durante os próximos anos os biossurfactantes sejam conhecidos como "materiais multifuncionais" (BANAT et al, 2010; CAMPOS et al, 2013).

\subsubsection{Micro-organismos produtores e métodos de seleção}

Nas últimas décadas, houve um aumento no interesse científico quanto ao isolamento de micro-organismos capazes de produzir moléculas tensoativas com boas características surfactante, como um baixo CMC, baixa toxicidade e alta atividade emulsionante (SILVA et al., 2014b). Acredita-se que os micro-organismos secretam os biossurfactante no meio de cultivo para auxiliar seu crescimento por facilitar o transporte e translocação de substratos insolúveis através das membranas celulares, além de conferir propriedades de aderência/liberação da célula a superfície permitindo colonização ou desligamento de ambientes desfavoráveis à sobrevivência e possuir atividade antimicrobiana, o que confere adaptação e vantagens competitivas ao micro-organismo (NITSCHKE; PASTORE, 2002; CAMPOS et al., 2013).

A maioria dos biossurfactantes é liberada no meio de cultura durante a fase estacionária ou na fase final de crescimento exponencial do micro-organismo produtor, sendo um metabólito secundário (RON; ROSENBERG, 2001). Entretanto, com relação à cinética, existem outros diferentes sistemas relatados na literatura, sendo estes: a produção associada ao crescimento; a produção em condições de limitação do crescimento; a produção por células em repouso ou imobilizadas; e finalmente, a produção com suplementação precursora. Na produção associada ao crescimento, são encontradas relações paralelas entre o crescimento, o uso do substrato e a produção de biossurfactantes. A produção em condições limitantes de crescimento é caracterizada por um aumento acentuado da concentração de biossurfactante como resultado da limitação de um ou mais componentes do meio de cultivo. A produção por células em repouso ou imobilizadas é um tipo de produção de biossurfactante em que não há multiplicação celular, as células, no entanto, continuam a usar a fonte de carbono para a síntese de biossurfactantes. 
Além disso, a adição de precursores e indutores de biossurfactantes ao meio leva a mudanças qualitativas e quantitativas no produto final (DESAI; BANAT, 1997; SANTOS et al., 2016).

$\mathrm{Na}$ literatura, a maior parte dos trabalhos relatam a produção de biossurfactantes por bactérias, principalmente dos gêneros Bacillus sp., Pseudomonas sp., Acinetobacter sp. e Arthobacter sp. (PIRÔLLO, 2006; BUENO, 2008; BUGAY, 2009; VATSA et al., 2010; CHEBBI et al., 2017). Porém, a aplicação da maioria dos biossurfactantes de origem bacteriana possui limitações, pois não é adequada para utilização na indústria alimentícia e farmacêutica, devido a sua possível natureza patogênica (SHEPHERD et al., 1995; FONTES et al., 2008; ELSHIKH et al., 2017).

Também existem, em menor proporção, relatos na literatura da produção de biossurfactantes por algumas leveduras, principalmente Candida lipolytica, Torulopsis bombicola e Rhodotorula glutinis (VAN-HAMME et al., 2006; GARAY et al., 2017), e fungos filamentosos como Aspergillus fumigatus e Phialemonium sp. (MARTINS et al., 2008; CASTIGLIONI, et al., 2009). Porém, os fungos filamentosos, devido ao crescimento mais lento, levam mais tempo para produzir o biossurfactante. Desta forma, as leveduras destacamse por apresentarem características promissoras para a produção industrial de biossurfactantes (NITSCHKE; PASTORE, 2002).

Existem diversos métodos de identificação e seleção de micro-organismos produtores de biossurfactantes, principalmente baseados em sua atividade tensoativa e emulsionante (SATPUTE et al., 2010). Os principais métodos utilizados estão apresentados na Tabela 3.

Tabela 3 - Principais métodos de seleção de micro-organismos produtores de biossurfactantes, seus fundamentos e desvantagens

\begin{tabular}{|c|c|c|c|}
\hline Método & Fundamento & Desvantagem & Referência \\
\hline $\begin{array}{c}\text { Placa de ágar } \\
\text { coberta por } \\
\text { hidrocarbonetos }\end{array}$ & $\begin{array}{c}\text { Capacidade } \\
\text { emulsionante do } \\
\text { biossurfactante }\end{array}$ & $\begin{array}{c}\text { Pouco sensível para } \\
\text { biossurfactantes que possuem } \\
\text { atividade tensoativa e baixa } \\
\text { atividade emulsificante }\end{array}$ & $\begin{array}{c}\text { MORIKAWA et } \\
\text { al. (1992) }\end{array}$ \\
\hline $\begin{array}{c}\text { Análise da gota } \\
\text { assimétrica }\end{array}$ & $\begin{array}{c}\text { Atividade } \\
\text { tensoativa do } \\
\text { biossurfactante }\end{array}$ & $\begin{array}{c}\text { Pouco sensível para } \\
\text { biossurfactantes que possuem } \\
\text { atividade emulsionante e } \\
\text { baixa atividade tensoativa }\end{array}$ & $\begin{array}{c}\text { VAN Der } \\
\text { VEGET et al. } \\
\text { (1991) }\end{array}$ \\
\hline
\end{tabular}

Continua 
Continuação

\begin{tabular}{|c|c|c|c|}
\hline Método & Fundamento & Desvantagem & Referência \\
\hline $\begin{array}{c}\text { Análise da } \\
\text { hidrofobicidade } \\
\text { da superfície } \\
\text { celular }\end{array}$ & $\begin{array}{c}\text { Correlação direta } \\
\text { entre a } \\
\text { hidrofobicidade } \\
\text { celular e a } \\
\text { produção de } \\
\text { biossurfactante }\end{array}$ & $\begin{array}{l}\text { Não avalia o tipo de atividade } \\
\text { do biossurfactante produzido }\end{array}$ & $\begin{array}{l}\text { ROSENBERG et } \\
\text { al. (1980) }\end{array}$ \\
\hline Colapso da gota & $\begin{array}{c}\text { Atividade } \\
\text { tensoativa do } \\
\text { biossurfactante }\end{array}$ & $\begin{array}{l}\text { Pouco sensível, não detecta } \\
\text { baixas concentrações de } \\
\text { biossurfactantes }\end{array}$ & $\begin{array}{c}\text { BODOUR e } \\
\text { MAIER (1998) }\end{array}$ \\
\hline $\begin{array}{l}\text { Espalhamento } \\
\text { da gota de óleo }\end{array}$ & $\begin{array}{c}\text { Atividade } \\
\text { tensoativa no } \\
\text { biossurfactante }\end{array}$ & $\begin{array}{l}\text { Pouco sensível para } \\
\text { biossurfactantes que possuem } \\
\text { atividade emulsionante e baixa } \\
\text { atividade tensoativa }\end{array}$ & $\begin{array}{l}\text { MORIKAWA et } \\
\text { al. (2000) }\end{array}$ \\
\hline $\begin{array}{l}\text { Escorrimento da } \\
\text { gota na lâmina } \\
\text { de vidro }\end{array}$ & $\begin{array}{c}\text { Atividade } \\
\text { tensoativa do } \\
\text { biossurfactante }\end{array}$ & $\begin{array}{l}\text { Pouco sensível para } \\
\text { biossurfactantes que possuem } \\
\text { atividade emulsionante e baixa } \\
\text { atividade tensoativa }\end{array}$ & $\begin{array}{c}\text { PERSSON e } \\
\text { MOLIN (1987) }\end{array}$ \\
\hline $\begin{array}{c}\text { Método em } \\
\text { placa de Blue } \\
\text { agar }\end{array}$ & $\begin{array}{c}\text { Formação de um } \\
\text { complexo entre o } \\
\text { glicolipídeo, o } \\
\text { CETAB } \\
\text { (cetiltrimetil- } \\
\text { brometo de } \\
\text { amônio) e Azul de } \\
\text { metileno }\end{array}$ & $\begin{array}{l}\text { Específico somente para } \\
\text { biossurfactantes do tipo } \\
\text { glicolipídeos }\end{array}$ & $\begin{array}{c}\text { SIEGMUND e } \\
\text { WAGNER (1991) }\end{array}$ \\
\hline $\begin{array}{c}\text { Atividade } \\
\text { emulsificante }\end{array}$ & $\begin{array}{l}\text { Atividade } \\
\text { emulsionante do } \\
\text { biossurfactante }\end{array}$ & $\begin{array}{l}\text { Pouco sensível para } \\
\text { biossurfactantes com atividade } \\
\text { tensoativa e não emulsionante }\end{array}$ & $\begin{array}{c}\text { PATIL e } \\
\text { CHOPADE } \\
(2001)\end{array}$ \\
\hline
\end{tabular}

Continua 
Conclusão

\begin{tabular}{|c|c|c|c|}
\hline Método & Fundamento & Desvantagem & Referência \\
\hline $\begin{array}{l}\text { Atividade } \\
\text { hemolítica }\end{array}$ & $\begin{array}{l}\text { Atividade tensoativa do } \\
\text { biossurfactante, a qual } \\
\text { leva ao rompimento da } \\
\text { membrada dos } \\
\text { heritrócitos }\end{array}$ & $\begin{array}{l}\text { Possibilidade de falsos } \\
\text { positivos devido à } \\
\text { produção de outros } \\
\text { metabólitos como } \\
\text { toxinas que podem ter } \\
\text { atividade hemolítica }\end{array}$ & BANAT (1993) \\
\hline $\begin{array}{c}\text { Índice de } \\
\text { emulsificação }\end{array}$ & $\begin{array}{l}\text { Atividade emulsionante } \\
\text { dos biossurfactantes }\end{array}$ & $\begin{array}{c}\text { Pouco sensível para } \\
\text { biossurfactantes que } \\
\text { possuem atividade } \\
\text { tensoativa e baixa } \\
\text { atividade emulsificante }\end{array}$ & $\begin{array}{c}\text { COOPER e } \\
\text { GOLDENBERG } \\
(1987)\end{array}$ \\
\hline $\begin{array}{l}\text { Medida de } \\
\text { tensão } \\
\text { superficial }\end{array}$ & $\begin{array}{c}\text { Atividade tensoativa dos } \\
\text { biossurfactantes }\end{array}$ & $\begin{array}{c}\text { Avalia somente a } \\
\text { atividade tensoativa do } \\
\text { biossurfactante }\end{array}$ & $\begin{array}{c}\text { DUNUOY } \\
(1925)\end{array}$ \\
\hline $\begin{array}{c}\text { Ferramentas } \\
\text { moleculares } \\
\text { para identificar } \\
\text { genes } \\
\text { produtores de } \\
\text { biossurfactantes }\end{array}$ & $\begin{array}{c}\text { Identificação dos genes } \\
\text { produtores de } \\
\text { biossurfactantes no DNA } \\
\text { do micro-organismo }\end{array}$ & $\begin{array}{l}\text { Técnica mais cara e que } \\
\text { exige mais estrutura. É } \\
\text { recomendada para a } \\
\text { confirmação após uma } \\
\text { seleção primária } \\
\text { utilizando métodos mais } \\
\text { tradicionais }\end{array}$ & $\begin{array}{l}\text { MORITA et al. } \\
\text { (2006) }\end{array}$ \\
\hline
\end{tabular}

Fonte: Arquivo pessoal.

Apesar dos diferentes métodos de seleção de micro-organismos disponíveis, ainda é difícil detectar a produção de todos os tipos de biossurfactantes produzidos utilizando apenas um dos métodos, devido à variedade química e funcional (tensoativa/emulsificante) destas moléculas, por isso uma combinação de vários métodos é necessária para uma seleção mais efetiva (SATPUTE et al., 2010).

Muitos trabalhos utilizam dois ou três métodos de seleção de micro-organismos produtores de biossurfactantes, principalmente índice de emulsificação, espalhamento da gota e atividade hemolítica (PLAZA et al., 2006; RODRIGUES et al., 2006; TECHAOEI et al., 
2007; BELGACEM et al., 2015; CHEN et al, 2007). Entretanto, Satpute e colaboratores (2008) em seu trabalho avaliaram a eficácia de oito diferentes métodos de seleção (atividade hemolítica, espalhamento da gota, escorrimento da gota na lâmina de vidro, colapso da gota, placa de ágar coberta por hidrocarbonetos, método em placa de Blue agar, índice de emulsificação e atividade emulsificante) e concluíram que a utilização dos testes de espalhamento da gota, escorrimento da gota na lâmina de vidro, método em placa de Blue agar, índice de emulsificação, colapso da gota e atividade emulsificante são os mais recomendados para uma seleção preliminar confiável.

2.2.4 Vantagem da utilização de leveduras e fungos leveduriformes (“yeastlike")

Fungos leveduriformes se diferem de leveduras verdadeiras porque existem como leveduras mas podem apresentar hifas em diferentes fases do ciclo de vida (SKINNER, 1947). Um exemplo clássico de fungo leveduriforme é a Candida albicans que apresenta conhecido dimorfismo (MITCHEL, 1998).

O estudo de leveduras e fungos leveduriformes para a produção de biossurfactante apresenta-se como uma oportunidade e vem se tornando cada vez mais explorado, principalmente espécies de Candida sp. e Yarrowia sp. A busca por fungos leveduriformes que apresentam um grau de segurança assegurado, ou status GRAS, é importante e vantajoso, pois amplia a possibilidade de sua utilização em diversos setores, como na indústria farmacêutica e de alimentos (BARTH; GAILLARD; 1997; ELSHIKH et al., 2017.; FONTES et al., 2008; CAMPOS et al., 2013). O fungo leveduriforme Aureobasidium pullulans é um exemplo, apresentando produção de biossurfactante e não apresentando patogenicidade (KIM et al., 2015; JADHAV e GAWAI, 2013). Este fungo leveduriforme foi classificado como Grupo-I pela World Health Organization (WHO) por não apresentar risco de infecção para a sociedade ou trabalhadores de laboratório (WORLD HEALTH ORGANIZATION, 1994).

Por apresentarem morfologia unicelular, leveduras e fungos leveduriformes apresentam mais fácil manipulação e manutenção e possuem crescimento mais acelerado que fungos filamentosos (MADIGAN, et al, 2014).

Além disso, as leveduras e fungos leveduriformes apresentam a vantagem de possuir maior resistência a altas concentrações de biossurfactante no meio. Segundo Morita e colaboradores (2006) as bactérias são capazes de sintetizar biossurfactantes mas apresentam parede e membrana celular com estruturas mais sensíveis às elevadas concentrações de 
biossurfactantes acumuladas no meio durante a fermentação (COOPER; PADDOCK, 1984; MONTEIRO et al., 2010). Devido a esses fatores acima apresentados, a prospecção de leveduras e fungos leveduriformes produtores de biossurfactantes têm aumentado substancialmente (FONTES et al., 2008; AMARAL et al, 2010; GARAY et al., 2016; SOUZA et al., 2017).

Dentre as leveduras e fungos leveduriformes, o tipo mais comum de biossurfactante produzido é do tipo glicolipídeo, porém, também há relatos de complexos carboidrato-proteínalipídeo, carboidrato-proteína com suas estruturas químicas ainda não elucidadas ou ainda poliol lipídeos (AMARAL et al., 2010; KULAKOVSKAYA KULAKOVSKAYA, 2013; KUROSAWAA et al. 1994; KIM et al., 2015; GARAY et al., 2017).

\subsubsection{Influência de nutrientes e biossíntese}

Os nutrientes utilizados para a produção de biossurfactantes pelo micro-organismo influenciam na composição e nas características da molécula. A natureza e a disponibilidade da fonte de carbono e nitrogênio e a presença de fósforo, ferro, manganês e magnésio no meio de cultivo afetam a biossíntese destes compostos. Também são fatores importantes o $\mathrm{pH}$, temperatura, aeração e a forma de condução do processo (SAHARAN et al., 2012; AMARAL, 2010).

Por isso, para a obtenção de altos rendimentos na produção de biossurfactantes é de fundamental importância o conhecimento da composição ideal do meio e as condições mais favoráveis para a condução do processo fermentativo (FONTES et al., 2008).

A influência da fonte de carbono na produção de biossurfactante é significativamente estudada e diversos tipos têm sido relatados na literatura, sendo que a maior parte deles utilizam fontes apolares de carbono. Entretanto, leveduras também são capazes de produzir biossurfactantes a partir de fontes de carbono polares como carboidratos ou a mistura de fontes polares e apolares, sendo que as fontes apolares podem funcionar como agentes indutores da produção de biossurfactantes (HOMMEL et al., 1994; AMARAL et al., 2010).

As fontes de carbono polares, como carboidratos, são utilizadas primeiramente pelo micro-organismo para o metabolismo celular e para a síntese da porção polar da molécula de biossurfactante, enquanto que os substratos apolares, como óleos, são utilizados exclusivamente para a produção da porção hidrocarbônica do biossurfactante (FONTES et al., 2008). 
A produção comercial dos biossurfactantes produzidos por leveduras dos tipos soforolipídeos, manosil eritritol lipídeos, celobiose lipídeos atualmente utilizam ambas fontes de carbono hidrofóbica (como óleos vegetais) e hidrofílica (como a glicose) (GARAY et al., 2017). Entretanto, a produção de polióis lipídeos por leveduras é reportada na literatura sem a utilização de fonte de carbono hidrofóbica (LEATHERS et al., 2015; GARAY et al., 2017).

As vias biossintéticas envolvidas na formação de precursores da síntese de biossurfactante são diversas e dependem da natureza da fonte de carbono utilizada no meio de cultivo (FONTES, 2008).

Quando se utiliza fontes polares como carboidratos e glicerol como fonte de carbono no meio de cultivo para a produção de glicolipídeos ou poliol lipídeos, o fluxo de carbono é regulado de forma a direcionar as vias lipogênicas para a formação da porção hidrofóbica, e vias glicolíticas para a formação da porção hidrofílica (FONTES et al., 2008; LI et al., 2015).

O metabolismo biossíntético das frações hidrofílicas e hidrofóbicas dos principais biossurfactantes produzidos por leveduras e fungos leveduriformes (glicolipídeos e poliol lipídeos) a partir de fontes polares de carbono encontra-se apresentado na Figura 4. Na biossíntese o substrato hidrofílico utilizado (como hexoses, pentoses, glicerol ou outros) é degradado até formar intermediários da via glicolítica, como a glicose 6-fosfato que é um dos principais precursores dos carboidratos presentes na porção hidrofílica do biossurfactante. Para a produção da fração lipídica, o piruvato produzido na via glicolítica é então convertido a acetilCoA, que, unida ao oxaloacetato produz malonil-CoA e, em seguida, ácido graxo, um dos precursores para a síntese de lipídeos (FONTES et al., 2008).

No caso da produção de polióils lipídios por A. pullulans, Li e colaboradores (2015) reportaram que a síntese da fração hidrofóbica da molécula (ácido 3,5-dehidroxidecanóico) pode ocorrer de acordo com a via de biossíntese de ácidos graxos hidroxilados em microorganismos oleaginosos, não sendo necessária assim a utilização de uma fonte de carbono hidrofóbica para induzir a sua síntese (RATLEDGE et al., 2004; SCHUMANN; HERTWECK et al., 2006).

Ainda no caso da síntese de poliol lipídeo, a frutose apresenta-se como importante precursor para a síntese dos polióis de seis carbonos, especialmente o manitol (GRAÇA, 2004). Os polióis também podem ser sintetizados diretamente a partir de pentoses, pela ação das enzimas redutase ou pela redução de intermediários da via das pentoses fosfato, dependendo do equilíbrio redox no meio intracelular (SILVA et al., 1994; ESCALANTE et al., 1990). 
Figura 4 - Biossíntese de precursores da produção de biossurfactantes a partir da utilização de carboidratos e/ou glicerol como fonte de carbono

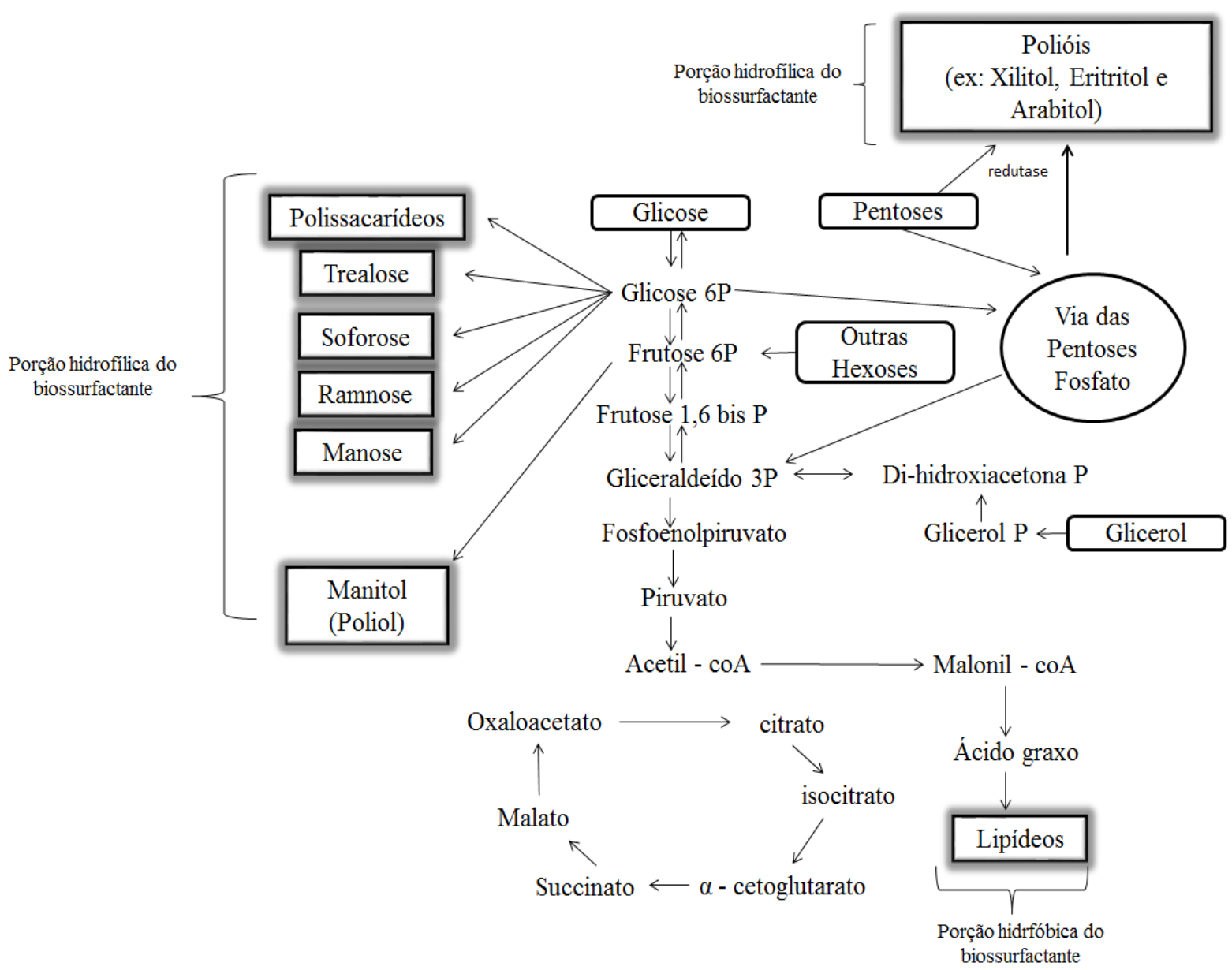

Fonte: Adaptado (FONTES et al., 2008).

Entretanto, quando se utiliza uma fonte de carbono apolar como alcanos e óleos, o metabolismo microbiano se dirige principalmente à via lipolítica e gliconeogênese, podendo assim produzir carboidratos (pela via da gliconeogênese). Para tanto, os ácidos graxos são oxidados via $\beta$-oxidação a acetil-coA ou propionil-coA (no caso de ácidos graxos de cadeia ímpar). A partir do acetil-coA as reações da gliconeogênese ocorrem no sentido contrário da via glicolítica (necessitando de algumas enzimas exclusivas da gliconeogênese para contornar as reações catalisadas pela fosfofrutoquinase e piruvato quinase, que são irreversíveis), levando à produção de intermediários da síntese de carboidratos, como a glicose-6P e frutose-6P (FONTES et al., 2008; WEBER et al., 1992).

O metabolismo biossíntético das frações hidrofílicas e hidrofóbicas dos principais biossurfactantes produzidos por leveduras e fungos leveduriformes (glicolipídeos e poliol lipídeos) a partir de fontes apolares de carbono encontra-se apresentado na Figura 5. 
Figura 5 - Biossíntese de precursores da produção de biossurfactantes a partir da utilização de hidrocarbonetos apolares como fonte de carbono

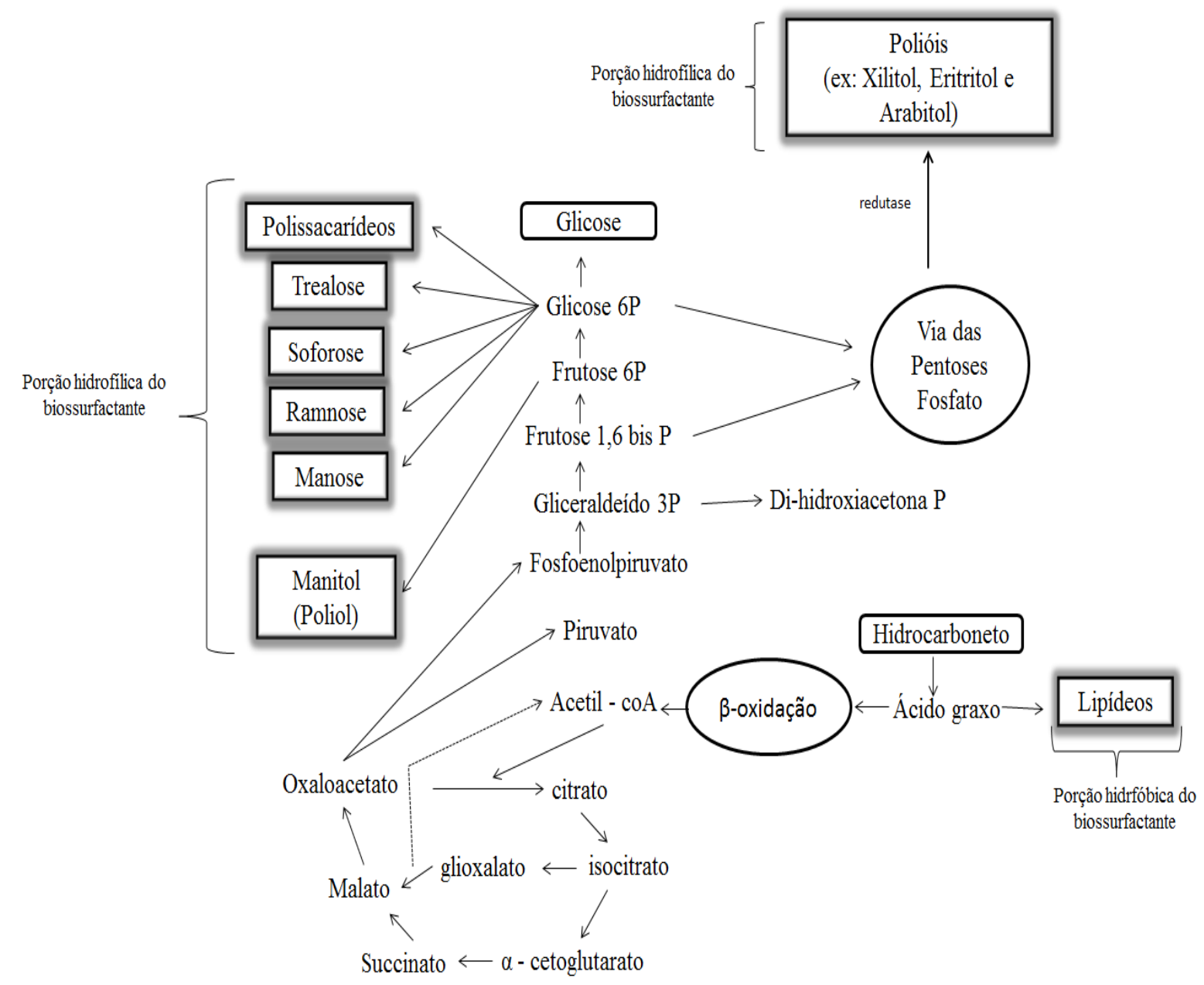

Fonte: Adaptado (FONTES et al., 2008).

Segundo Sydatk e Wagner (1987), a biossíntese de biossurfactantes pode acontecer seguindo quatro caminhos diferentes:

- síntese do carboidrato e do lipídeo;

- síntese da parte polar do biossurfactante, enquanto que a síntese da parte apolar (lipídica) da molécula dependerá do comprimento da cadeia do substrato carbônico presente no meio;

- síntese da parte apolar do biossurfactante enquanto que a síntese da parte polar (glicídica ou poliol) dependerá do substrato utilizado;

- síntese da parte polar e apolar do biossurfactante dependendo do substrato.

Além da fonte de carbono, a fonte de nitrogênio é essencial para o crescimento celular e é essencial para a síntese de enzimas, que são os agentes catalizadores da biossíntese de moléculas de interesse. Muitas fontes de nitrogênio orgânicas e inorgânicas são utilizadas para 
a produção de biossurfactantes, como milhocina, extrato de soja, extrato de malte, uréia, peptona, extrato de levedura, sulfato de amônio, nitrato de amônio, cloreto de amônio e nitrato de sódio, sendo o extrato de levedura a mais utilizada (AMARAL, et al., 2010; FONTES et al., 2008; LEATHERS et al., 2015). Muitas vezes também é utilizada uma mistura de fontes de nitrogênio, como nos trabalhos relatados por Lima e Alegre (2009), Pruthi e Cameotra (1997), Cooper e Paddock (1983) e Zinjarde e Pant (2002).

Um fator de grande importância na biossíntese de biossurfactantes por leveduras é a proporção entre fontes de carbono e nitrogênio (relação C/N). Casas e Ochoa (1999), ao avaliar a produção de soforolipídeos utilizando Candida bombicola, relataram que o excesso de fonte de nitrogênio, ou seja, uma baixa relação $\mathrm{C} / \mathrm{N}$, diminui a produção de biossurfactantes, desviando o metabolismo da levedura para a produção de biomassa.

A comprovação da importância dessa relação $\mathrm{C} / \mathrm{N}$ foi feita por Albrecht e colaboradores (1996), que observaram que uma elevada relação C/N, causa uma redução na atividade da enzima isocitrato desidrogenase, responsável pela oxidação do isocitrato a $\alpha$-cetoglutarato no ciclo de Krebs. A redução da atividade desta enzima ocasiona um acúmulo de isocitrato e, consequentemente, citrato nas mitocôndrias. Estes dois metabólitos são transportados até o citosol, onde o citrato é clivado pela enzima citrato sintase, originando acetil-CoA, que é o metabólito precursor da síntese de ácidos graxos, e assim aumenta a produção do biossurfactante.

A presença de outros micronutrientes como fósforo, ferro, manganês, magnésio e vitaminas são importantes, pois estes atuam como cofatores de enzimas e fatores de crescimento importantes no metabolismo microbiano, entretanto a concentração ideal destes micronutrientes varia de acordo com a espécie utilizada (MADIGAN et al., 2014).

\subsubsection{Influência dos parâmetros operacionais do processo}

O entendimento da influência dos parâmetros operacionais (aeração, agitação, pH e temperatura) para a produção de biossurfactantes é essencial para a melhoria do processo (FONTES et al., 2008).

A aeração e a agitação são de grande importância na produção de biossurfactantes por leveduras, pois facilitam a transferência de oxigênio no meio. Entretanto, esses parâmetros devem ser bem estabelecidos, pois também influenciam na formação de espuma, um ponto crítico no processo de produção de biossurfactantes, uma vez que retira do meio reacional parte 
do biossurfactante, biomassa e substrato (ADAMCZAK; BEDNARSK, 2000; FONTES et al., 2008).

Santos e colaboradores (2014) estudaram o efeito da agitação (200, 300 e 400 rpm) e da aeração (0,0; 1,0 e 2,0 vvm) na produção de biossurfactantes por Candida lipolytica UCP0988, e observaram que a redução da tensão superficial $(<20 \mathrm{mN} / \mathrm{m})$ ocorreu quando valores de agitação menores que $200 \mathrm{rpm}$ e 0 vvm de aeração foram utilizados. Quando valores maiores que $320 \mathrm{rpm}$ e aeração acima de 1 vvm foram utilizados, os maiores valores de tensão superficial foram obtidos (> $40 \mathrm{mN} / \mathrm{m}$ ). Em outro estudo, Adamczak e Bednarsk (2000) observaram que a maior produção de biossurfactante $(45,5 \mathrm{~g} / \mathrm{L})$ foi alcançada utilizando uma aeração de 1 vvm concentração de oxigênio dissolvido a 50\% do valor de saturação ao avaliar a influência da aeração na produção de biossurfactante por Candida antártica. Quando os autores utilizaram 2 vvm de aeração, houve uma intensa produção de espuma e a produção de biossurfactante foi $84 \%$ menor (ADAMCZAK; BEDNARSK, 2000). Entretanto, em estudo avaliando a influência da agitação (160 e $250 \mathrm{rpm}$ ) e da aeração (relação volume de frasco/volume de meio de 0,3 e 0,5) na produção de biossurfactantes por Yarrowia lipolytica, Fontes e colaboradores (2010) observaram que o aumento na agitação (250 rpm) e aeração (relação volume de frasco/volume de meio de 0,5 ) levaram à maior produção de biossurfactante.

Assim como os parâmentros de aeração e agitação, a condição de pH que leva à uma maior produção de biossurfactantes depende do micro-organismo estudado. Para a levedura Candida antartica foram testados diferentes valores de pHs com a adição de tampão fosfato (48); entretanto, a maior produção de biossurfactante foi observada no experimento sem tampão, que utilizou apenas água destilada (KITAMOTO et al., 2001). Contudo, em estudo realizado com a levedura Yarrowia lipolytica, demonstrou-se que a maior produção de biossurfactante ocorre em pH 8,0, (pH da água do mar) (ZINJARDE; PANT, 2002). Para Pichia anamola o maior rendimento de biossurfactante foi reportado no $\mathrm{pH}$ de 5,5 (THANIYAVARN et al., 2008).

A temperatura usualmente reportada para a produção de biossurfactantes na literatura para a maioria das leveduras é entre 25 e $30{ }^{\circ} \mathrm{C}$ (AMARAL et al., 2010). Para diversas espécies como Candida bombicola, Candida antártica, Yarrowia lipolytica e Rhodotorula glutinis a temperatura de $30{ }^{\circ} \mathrm{C}$ favoreceu a produção de biossurfactantes (CASAS; OCHOA, 1999; ADAMCZAK e BEDNARSKI, 2000; ZINJARDE; PANT, 2002). Entretanto para espécies como Aureobasidium pullulans, Yarrowia lipolytica e Candida tropicalis a temperatura de 28 ${ }^{\circ} \mathrm{C}$ é a mais utilizada para produção de biossurfactantes (LEATHERS et al., 2015; BATISTA et al., 2010; FONTES et al., 2010). 
2.2.7 Processos de recuperação do biossurfactante

A recuperação do biossurfactante produzido é um dos desafios enfrentados para a viabilização da sua produção em grande escala. Isso porque de maneira geral são processos complexos e que aumentam o custo de produção dessas moléculas (SANTOS et al., 2016). O custo dos processos de downstream representa, em média de 70 a $80 \%$ dos custos de produtos obtidos por vias biotecnológica (MARCHANT; BANAT, 2012).

No processo de recuperação existe o risco de contaminação por outros compostos produzidos na fermentação, e por isso o método utilizado depende de características específicas da molécula do biossurfactante em questão, principalmente da sua carga iônica, solubilidade e sua localização (ligação intracelular ou extracelular) (SATPUTE et al., 2010). Os métodos descritos na literatura para a recuperação de biossurfactantes envolvem a extração com clorofórmio-metanol, diclorometano-metanol, butanol, butanona, acetato de etilo, pentano, hexano, ácido acético, éter, entre outros. A extração com solventes constitui o método mais utilizado na recuperação de biossurfactantes. Entretanto, este método apresenta desvantagens devido à grande quantidade de solvente requerida e o aumento nos custos de produção devido ao preço de solventes (DESAI; BANAT, 1997). O clorofórmio é um haleto orgânico tóxico que prejudica a saúde humana e o meio ambiente. Assim, há uma necessidade de solventes baratos com baixa toxicidade para processos de extração de biossurfactantes que sejam adequados para aplicações industriais (SANTOS et al., 2016). Outras técnicas de precipitação de produtos também foram relatadas, tais como precipitação com sulfato de amônio seguido de diálise (TOREN et al., 2002), precipitação ácida, em acetona ou álcool (MUKHERJEE et al., 2006; PATIL; CHOPADE, 2001; PHETRONG et al., 2008), adsorção (DUBEY et al., 2005), cromatografia de troca iônica (MATSUFUJI et al., 1997), cristalização (MANSO PAJARRON et al., 1993), ultrafiltração (LIN; JIANG, 1997) e fracionamento de espuma (COOPER et al., 1981). Entretanto, cada método possui vantagens e desvantagens associadas e deve ser utilizado de acordo com as características da molécula de biossurfactante produzida. Na Tabela 4 estão apresentados os diferentes processos de recuperação de importantes biossurfactantes e suas vantagens. 
Tabela 4 - Processos de downstream para recuperação de biossurfactantes importantes e respectivas vantagens

\begin{tabular}{|c|c|c|c|}
\hline Processo & Biosurfactante & $\begin{array}{c}\text { Propriedade responsável } \\
\text { pela separação }\end{array}$ & Vantagens \\
\hline $\begin{array}{l}\text { Extração com } \\
\text { solvente }\end{array}$ & $\begin{array}{l}\text { Trealose } \\
\text { lipídeos; } \\
\text { Soforolipídeos; } \\
\text { Liposan }\end{array}$ & $\begin{array}{l}\text { Biosurfactantes são solúveis } \\
\text { em solventes orgânicos } \\
\text { devido à sua porção } \\
\text { hidrofóbica }\end{array}$ & $\begin{array}{l}\text { Eficiente na } \\
\text { recuperação do } \\
\text { biossurfactante bruto. } \\
\text { Purificação parcial. } \\
\text { Possibilidade de } \\
\text { reutilização do } \\
\text { solvente }\end{array}$ \\
\hline $\begin{array}{l}\text { Preciptação } \\
\text { ácida }\end{array}$ & Surfactin & $\begin{array}{l}\text { Biossurfactante se torna } \\
\text { insolúvel em baixos valores } \\
\text { de } \mathrm{pH}\end{array}$ & $\begin{array}{l}\text { Baixo custo, eficiente } \\
\text { para a recuperação do } \\
\text { biossurfactante bruto }\end{array}$ \\
\hline $\begin{array}{l}\text { Preciptação com } \\
\text { sulfato de } \\
\text { amônio }\end{array}$ & $\begin{array}{l}\text { Emulsan; } \\
\text { Biodispersan; } \\
\text { Lipopeptídeos }\end{array}$ & $\begin{array}{l}\text { Salting-out de biosurfactantes } \\
\text { poliméricos ou ricos em } \\
\text { proteínas }\end{array}$ & $\begin{array}{l}\text { Eficaz para o } \\
\text { isolamento de alguns } \\
\text { tipos de } \\
\text { biossurfactantes } \\
\text { poliméricos }\end{array}$ \\
\hline $\begin{array}{l}\text { Adsorção em } \\
\text { carvão ativado } \\
\text { ou resinas de } \\
\text { poliestireno }\end{array}$ & $\begin{array}{l}\text { Ramnolipídeos; } \\
\text { Lipopeptídeos; } \\
\text { Glicolipídeos; } \\
\text { Manosileritritol } \\
\text { lipídeos (MEL) }\end{array}$ & $\begin{array}{l}\text { Os biossurfactantes são } \\
\text { adsorvidos ao carvão ativado } \\
\text { ou a resina e podem ser } \\
\text { dessociados utilizando } \\
\text { solventes orgânicos }\end{array}$ & $\begin{array}{l}\text { Biossurfactantes } \\
\text { altamente puros, } \\
\text { processo de menor } \\
\text { custo, reagentes } \\
\text { reutilizáveis, e pode } \\
\text { ser empregado em } \\
\text { processos contínuos }\end{array}$ \\
\hline $\begin{array}{l}\text { Cromatografia } \\
\text { de troca iônica }\end{array}$ & Glicolipídeos & $\begin{array}{l}\text { Os biossurfactantes } \\
\text { carregados se ligam a resinas } \\
\text { de troca iônica e podem ser } \\
\text { eluídos com tampão }\end{array}$ & $\begin{array}{l}\text { Biossurfactantes com } \\
\text { alto grau de pureza, } \\
\text { reagentes } \\
\text { reutilizáveis, e rápida } \\
\text { recuperação }\end{array}$ \\
\hline $\begin{array}{l}\text { Fracionamento } \\
\text { de espuma }\end{array}$ & Surfactin & $\begin{array}{l}\text { Separa moléculas de } \\
\text { biossurfante adsorvidas às } \\
\text { bolhas de ar da espuma } \\
\text { formada }\end{array}$ & $\begin{array}{l}\text { Pode ser utilizada em } \\
\text { processos contínuos }\end{array}$ \\
\hline Ultrafiltração & Glicolipídeos & $\begin{array}{l}\text { Os biossurfactantes formam } \\
\text { micelas acima concentração } \\
\text { micelar crítica }\left(\mathrm{CMC}^{*}\right) \text {, que } \\
\text { são retidas por membranas } \\
\text { poliméricas }\end{array}$ & $\begin{array}{l}\text { Processo rápido, com } \\
\text { alto nível de pureza. }\end{array}$ \\
\hline
\end{tabular}

Fonte: Adaptado (Santos et al., 2016). 
A utilização de processos e reagentes menos agressivos e mais específicos para o biossurfactante produzido, além da otimização dos métodos de recuperação existentes, são essenciais para tornar esses processos comercialmente viáveis e mais competitivos (SATPUTE et al., 2010; SANTOS et al., 2016).

\subsection{Processos fermentativos de produção dos biossurfactantes}

Os processos fermentativos são comumente classificados quanto à condução do processo e quanto ao modo de cultivo, ou seja, processos contínuos, descontínuo ou semicontínuo, e processos em estado sólido e submerso (REGULY, 2000). Para a produção de biossurfactantes por leveduras se utiliza principalmente processos descontínuos ou semicontínuos em processos de fermentação submersa. A escolha adequada da forma de condução do processo é um passo importante, uma vez que pode alterar a produtividade do produto desejado (FONTES et al., 2008; AMARAL et al., 2010).

O controle e a otimização das condições operacionais da fermentação também são fatores fundamentais para o sucesso da ampliação de escala de produção de biossurfactantes, capazes de torná-los economicamente competitivos em relação aos surfactantes químicos (BANAT et al., 2010).

\subsubsection{Fermentação submersa (FS)}

A fermentação submersa é amplamente utilizada em processos biotecnológicos e é caracterizada pela utilização de um meio fermentativo líquido, com nutrientes solúveis, no qual o micro-organismo fica submerso (GIBBS et al., 2000).

Os estudos de produção de biossurfactantes vêm sendo conduzidos principalmente em fermentação submersa. A quantidade de biossurfactantes produzida por fermentação submersa varia conforme o tipo e a escala de processo, o meio e as condições de cultivo utilizadas (CAMILIOS NETO et al, 2011).

Algumas dificuldades importantes vêm sendo encontradas para o processo fermentativo em reatores pilotos ou de larga escala nos processos de produção de tensoativos (CAMILIOS NETO et al., 2011; LOTFABAD et al., 2015). Por serem conduzidos com agitação e aeração forçada, quando o biossurfactante começa a ser produzido, grande quantidade de espuma é formada, levando à perda de biomassa, nutrientes e produtos contidos na espuma que é expelida 
do reator, o que diminui os parâmetros de produção ou em casos extremos inviabiliza o processo (LEE; KIM, 2004; YEH et al., 2006; KRIEGER et al., 2010).

Para solucionar a questão da formação de espuma existem estratégias como a utilização de agentes antiespumantes ou uso de equipamentos projetados para quebrar a espuma ou sua recirculação (LOTFABAD et al., 2015; WILLENBACHER et al., 2015). Porém há algumas desvantagens na sua utilização, pois os antiespumantes interferem na transferência de $\mathrm{O}_{2}$ e $\mathrm{CO}_{2}$ entre as fases líquida e gasosa e podem provocar reações inibitórias e efeitos tóxicos ao microorganismo, além disso, representam um "contaminante químico" que tem que ser separado do produto final, o que encarece ainda mais o processo de produção (KRIEGER et al., 2010; CAMILIOS NETO, 2010; WILLENBACHER et al., 2015).

Os quebradores de espuma instalados no eixo do agitador apresentam capacidade limitada de contenção da espuma formada por biossurfactantes, que é muito mais intensa quando comparada à que ocorre na produção de outros tipos de compostos, não sendo efetivos. Desta forma, seria necessária a instalação de "quebradores externos com sistema coletor", de modo que haja recuperação da espuma formada de modo que seja convertida em líquido e volte ao reator, uma vez que na espuma contém biomassa, nutrientes e o biossurfactante (KRIEGER et al., 2010; LOTFABAD et al., 2015; WILLENBACHER et al., 2015). Este sistema deve ser asséptico e encarece significativamente a construção do reator e podem ocasionar a diminuição da eficiência do processo de produção, pois acarreta um maior número de etapas na fermentação (CAMILIOS NETO, 2010). Assim, novas estratégias e formas de condução de processos para a produção de biossurfactantes são priorizadas.

\subsubsection{Fermentação em estado sólido (FES)}

A fermentação em estado sólido (FES) se baseia no cultivo de micro-organismos nas superfícies de partículas orgânicas úmidas, dentro de um leito em que há uma fase gasosa contínua nos poros entre as partículas sólidas e há um mínimo de água líquida nestes poros, sendo restrita a filmes finos nas superfícies das partículas e umas poucas gotículas. A água necessária para o crescimento do micro-organismo encontra-se absorvida dentro das partículas do suporte (MITCHELL et al., 2006). A FES tenta reproduzir as condições do ambiente microbiológico natural do micro-organismo e já é conhecido desde a antiguidade nos países asiáticos com a produção de pães desde 2600 a.c. (COUTO; SANROMAN, 2006). 
O suporte sólido pode ser constituído por um substrato naturalmente úmido ou por uma matriz inerte capaz de absorver os nutrientes que se encontram em solução reproduzindo as condições de baixa atividade de água e alta transferencia de oxigênio (SOCCOL et al., 2002).

$\mathrm{O}$ ambiente fornecido ao micro-organismo neste sistema é bem diferente daquele fornecido pela fermentação submersa. A disponibilidade restrita de água pode estimular a produção de alguns metabólitos específicos, que não seriam produzidos na fermentação submersa (PANDEY, 2003; MITCHELL et al., 2006).

Outras vantagens do processo de fermentação em estado sólido são maiores rendimentos e produtividade volumétrica, menores custos de operação, menor custo do meio de cultivo (pois na maioria das vezes se utiliza resíduos agroindustriais como substrato), maior distribuição de oxigênio, menores problemas operacionais, equipamentos mais simples e menor consumo de energia (SANCHEZ et al., 2015; HOSSEINPOUR et al., 2012).

A FES tem sido utilizada para a produção de uma variedade significativa de produtos microbianos, incluindo metabólitos secundários biologicamente ativos (toxinas, antibióticos), enzimas, cogumelos, ácidos orgânicos, aminoácidos, na alimentação (laticínios, aromas), vitaminas, etanol e biopesticidas (VANDENBERGHE et al., 2000; PANDEY, 2003; HÖLKER; LENZ, 2005; HOSSEINPOUR et al., 2012; SANCHEZ et al., 2015).

Pouco foi estudado da produção de biossurfactantes por FES, e os registros encontrados na literatura referem-se à produção de biossurfactante por bactérias ou fungos filamentosos (CAMILIOS NETO, 2011; OHNO et al., 1995; DAS; MUKHERJEE, 2007; VEENANADIG et al., 2000 BUGAY, 2009). Assim, a presente proposta agrega um novo conceito e estratégia na produção microbiológica de biossurfactantes.

A FES é uma tecnologia simples aplicada nos estudos, sobretudo em escala de bancada, de produção de compostos interesse (MITCHELL et al., 2006). Esta tecnologia tem o potencial de viabilizar a produção de biossurfactantes, pois é uma alternativa que evita a formação de espuma, fator limitante da obtenção desses compostos por fermentação submersa (KRIEGER et al., 2010). No entanto, a produção de biossurfactantes por FES apresenta ainda algumas dificuldades próprias. A produção em larga escala é dificultada pelos problemas relacionados com a transferência de calor e de massa em biorreatores (DURAND, 2003). Por isso é importante que mais estudos utilizando este processo sejam desenvolvidos visando o melhoramento do processo. Também há a necessidade de projetar, construir e operar biorreatores que possam fornecer as condições mais próximas possíveis às condições ótimas de fermentação (MITCHELL et al., 2006; KRIEGER et al., 2010). 


\subsection{Utilização de resíduos agroindustriais para a produção de biossurfactantes}

Os investimentos em conhecimento e tecnologias que busquem reduzir impactos ambientais e que promovam o desenvolvimento sustentável vêm ganhando especial atenção nos últimos anos. A minimização e reuso de resíduos, o desenvolvimento e a implementação de processos sustentáveis capazes de gerar produtos com valor agregado a partir da conversão de biomassa apresentam-se como importantes oportunidades (ROSA et al, 2011).

É crescente o número de pesquisas que utilizam subprodutos agroindustriais na produção dos biossurfactantes, justificável pelo contexto de processos sustentáveis, uma das prioridades atuais, evitando danos ao meio ambiente e ao mesmo tempo não prejudicando o desenvolvimento econômico, além de reduzir os custos do processo produtivo, já que a fonte de carbono pode ser responsável por até $30 \%$ do valor do produto final (FONTES et al., 2008).

Na Tabela 5 está apresentada a utilização de subprodutos oriundos da agroindústria que são utilizados como substratos ricos em fontes de carbono glicídicas e lipídicas na produção de biossurfactantes.

Tabela 5 - Utilização de resíduos e subprodutos agroindustriais como substratos para produção de biossurfactantes por diferentes micro-organismos

\begin{tabular}{ccc}
\hline $\begin{array}{c}\text { Fonte de carbono e indutores } \\
\text { (resíduos e subprodutos) }\end{array}$ & Micro-organismo & Referência \\
\hline Óleo de soja queimado & Candida ishwadae & THANOMSUB et al., \\
n-hexadecano, oleo de soja, & Candida sp. & COIMBRA et al., \\
resíduo do refino de óleo de & & $(2009)$ \\
amendoim e milhocina & & THAVASI et al., \\
Oleo e cake de amendoim e & Bacillus megaterium & $(2008)$ \\
oleo de motor residual & & NITSCHKE; \\
Água residual de mandioca & Bacillus subtilis LB5a & PASTORE (2006) \\
Gordura vegetal residual & Candida glabrata & GUSMÃO et al., \\
& & $(2010)$ \\
\hline
\end{tabular}

Continua 
Conclusão

\begin{tabular}{|c|c|c|}
\hline $\begin{array}{l}\text { Fonte de carbono e indutores } \\
\text { (resíduos e subprodutos) }\end{array}$ & Micro-organismo & Referência \\
\hline $\begin{array}{l}\text { Glicerol residual da indústria } \\
\text { de biodiesel }\end{array}$ & Ustilago maydis & LIU et al., (2011) \\
\hline $\begin{array}{l}\text { Bagaço de cana-de-açúcar, } \\
\text { Glicerol residual, farelo de } \\
\text { milho e óleo de girassol }\end{array}$ & $\begin{array}{c}\text { Pseudomonas aeruginosa } \\
\text { UFPEDA } 614\end{array}$ & $\begin{array}{l}\text { CAMILIOS NETO, } \\
\qquad(2011)\end{array}$ \\
\hline $\begin{array}{c}\text { Casca e farelo de arroz, óleo de } \\
\text { soja, óleo diesel }\end{array}$ & Aspergillus fumigatus & $\begin{array}{l}\text { CASTIGLIONI et al., } \\
\text { (2009) }\end{array}$ \\
\hline $\begin{array}{l}\text { Hidrolisado hemicelulósico de } \\
\text { resíduo de vinhedo }\end{array}$ & Lactobcillus pentosus & VECINO et al., (2015) \\
\hline Oléo de soja residual & $\begin{array}{c}\text { Starmerella } \\
\text { bombicola (ATCC 22214) }\end{array}$ & $\begin{array}{l}\text { MADDIKERI et al., } \\
\qquad(2015)\end{array}$ \\
\hline
\end{tabular}

FONTE: Arquivo pessoal

A utilização de resíduos pode diminuir os custos de produção para níveis competitivos em relação aos já produzidos por diversas empresas, ao mesmo tempo, reduzir os problemas ambientais relativos ao descarte e aos custos do tratamento (MERCADE; MANRESA, 1994; MAKKAR; CAMEOTRA, 2002).

Novas propostas de produtos com alto valor agregado, como os biossurfactantes, obtidos de recursos renováveis e de baixo custo apresentam-se promissoras, pois além da potencialidade econômica, a crescente preocupação ambiental leva ao aumento em investimentos na pesquisa e desenvolvimento de novas tecnologias alternativas que busquem por produtos e processos que gerem menos impactos ambientais (gastam menos energia, geram menos poluentes e sejam biodegradáveis), promovendo o desenvolvimento sustentável (BRUMANO; SOLER; SILVA, 2016).

Nesse contexto, o conceito de biorrefinarias vem ganhando importância cada vez maior nos países desenvolvidos e em desenvolvimento, como o Brasil, mobilizando grandes quantias de recursos e esforços públicos e privados voltados para o aproveitamento otimizado da biomassa, para agregar valor a essas cadeias produtivas, além de reduzir seus possíveis impactos ambientais (VAZ Jr, 2012). Dentre os resíduos e subprodutos agroindustriais os lignocelulósicos são destacados, sobretudo pelos programas governamentais para o 
desenvolvimento de biocombustíveis, e mais recentemente, para a produção de bio based products, como biossurfactantes, visando à consolidação das biorrefinarias lignocelulósicas.

\subsubsection{Bagaço de cana-de-açúcar e agentes indutores}

O agronegócio possui grande importância no processo de desenvolvimento do Brasil e está em acentuado crescimento. O cultivo da cana-de-açúcar merece destaque, uma vez que o Brasil é o maior produtor da cultura, seguido por Índia e China, e também é o maior produtor de açúcar e etanol de cana-de-açúcar, sendo responsável por mais de 50\% do açúcar comercializado no mundo. A previsão da safra 2017/2018 é de 647,6 milhões de toneladas de cana-de-açúcar, segundo a Companhia Nacional de Abastecimento (2017).

O bagaço de cana é um dos subprodutos disponíveis em maior quantidade pelas indústrias sucro-alcoleiras. Estima-se que a cada tonelada de cana moída, são gerados $280 \mathrm{~kg}$ de bagaço (úmido), correspondendo a cerca de $30 \%$ do total da cana moída. Parte desta biomassa (60 a 90\%) é utilizada como combustível para geração de energia pela própria indústria, entretanto, o excedente ainda gera problemas ambientais e de estocagem (SUN et al., 2004).

O bagaço de cana-de-açúcar apresenta-se vantajoso por ser um material orgânico abundante, constituído principalmente por celulose, hemicelulose e lignina, os quais juntos perfazem mais de $90 \%$ da massa total (MOISER et al., 2005). Estas características fazem com que o bagaço possa ser utilizado como substrato, se o micro-organismo em questão for capaz de produzir enzimas hidrolases capazes de expor os açúcares do bagaço e torna-los disponíveis para a fermentação (CADETE, 2009). Ou ainda pode ser utilizado algum pré-tratamento (químico, físico ou enzimático) de forma a disponibilizar estes açúcares para o microorganismo (CHANDEL et al., 2014). O bagaço pode também servir de substrato inerte de suporte para o crescimento do micro-organismos na FES (CAMILIOS NETO et al., 2011).

Camilios Neto (2010) otimizou a produção de biossurfactantes utilizando a bactéria Pseudomonas aeruginosas por FES e observou que a utilização de bagaço de cana-de-açúcar é apropriada para a produção do biossurfactante do tipo raminolipídeo por proporcionar níveis de produção razoáveis e grande facilidade de extração do tensoativo, além de ser abundante, disponível e de baixo custo. Entretanto em seu trabalho o bagaço foi utilizado como um suporte essencialmente inerte e o autor utilizou como fonte de carbono o glicerol que foi acrescentado ao meio. A utilização de glicerol adicionado ao bagaço de cana-de-açúcar pode apresentar vantagens, pois esse é um indutor da produção de biossurfactante (JARVIS; JOHNSON, 1949), como já foi visto no ítem 2.2.6, participando da rota biossintética destas moléculas. Outra 
vantagem de se usar o glicerol é a disponibilidade desse composto, já que é um subproduto da produção do biodiesel. Na reação de transesterificação, que ocorre entre qualquer triglicerídeo (óleos e gorduras animais ou vegetais) e álcool de cadeia curta (metanol ou etanol), o glicerol contido no triglicerídeo é separado e substituído pelo álcool na cadeia. Esse processo gera como produto ésteres (biodiesel) e glicerina (subproduto) (MORITA et al., 2007).

Outros trabalhos também relataram a utilização do glicerol como fonte de carbono para a produção de biossurfactantes por outros micro-organismos, como o fungo filamentoso Ustilago maydis (LIU et al., 2011), as bactérias Pseudomonas Stutzeri BK-AB12 e Bacillus subtilis ATCC 6633 (PUTRI et al., 2015; SOUSA et al., 2012) e as levedura Pseudozyma antarctica e Yarrowia lipolytica (MORITA et al., 2007; FONTES et al., 2012).

A utilização de fontes de carbono apolares adicionadas ao bagaço de cana-de-açúcar, tais como óleos vegetais, também é uma alternativa para induzir e aumentar o rendimento do processo, pois como foi descrito no ítem 2.2.6, a adição de uma fonte de carbono apolar pode levar a um aumento na produção de biossurfactantes. A ação indutora de compostos apolares adicionados ao meio de cultivo está relacionada com a ação dos biossurfactantes como facilitadores do transporte e translocação de substratos insolúveis através das membranas celulares, pois o micro-organismo produtor seria induzido a aumentar a síntese e excreção de biossurfactantes para assimilar estes compostos como fonte de carbono (NITSCHKE; PASTORE, 2002; CAMPOS et al., 2013). Este fato foi confirmado por relatos na literatura em que a adição de óleos vegetais ou resíduos ricos em óleo como fonte de carbono, apresentaram melhores resultados na produção de biossurfactante, agindo como indutores (COSTA et al., 2006; BENINCASA; ACCORSINI, 2008). 


\section{OBJETIVOS}

\subsection{Geral}

Desenvolvimento de um processo de produção de biossurfactante por levedura utilizando fermentação em estado sólido (FES) empregando bagaço de cana-de-açúcar como matriz sólida, visando à obtenção de níveis de produção próximos aos obtidos por fermentação submersa.

\subsection{Específicos}

- Selecionar a levedura com maior potencial de produção de biossurfactantes por meio de fermentação em estado sólido utilizando bagaço de cana-de-açúcar;

- Avaliar diferentes fontes de carbono e a sua concentração adequada e o efeito da aeração para a produção de biossurfactante pela levedura selecionada;

- Avaliar a influência da adição de glicerol e adição de óleo de soja como indutores na produção de biossurfactantes na FES pela levedura selecionada;

- Avaliar a influência das variáveis tamanho médio de partícula de bagaço, volume de meio de cultivo adicionado ao bagaço, concentração celular inicial e volume de extração para estabelecer as melhores condições para o processo de FES;

- Determinar o método de extração mais adequado para o biossurfactante produzido na FES;

- Analisar a composição bioquímica do biossurfactante produzido;

- Determinar a produção de enzimas lignocelulolíticas pela levedura que apresentar melhor produção de biossurfactante por meio de FES afim de verificar o uso dos açúcares do bagaço de cana-de-açúcar como fonte de carbono;

- Avaliar a utilização do biossurfactante produzido em processo de biorremediação (oil recovery) 


\section{MATERIAL E MÉTODOS}

O fluxograma das atividades desenvolvidas no presente trabalho está apresentado na Figura 6. Cada etapa será descrita detalhadamente a seguir.

Figura 6 - Fluxograma das atividades desenvolvidas

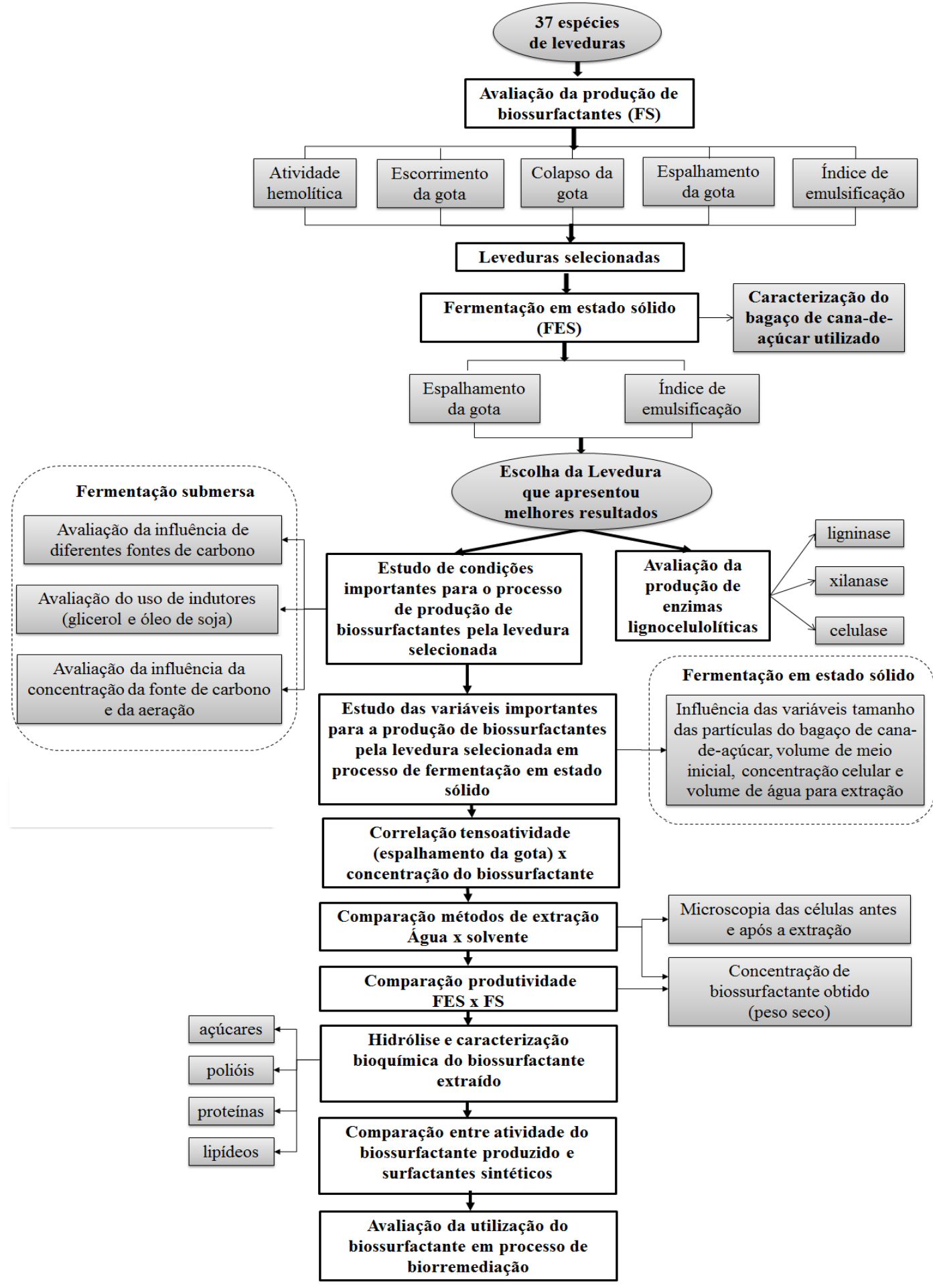

Fonte: Arquivo pessoal. 


\subsection{Micro-organismos}

Foram utilizadas 37 leveduras isoladas de biomas brasileiros e cedidas gentilmente pelo Prof. Dr. Carlos A. Rosa (UFMG) e Prof. Dr. Fernando C. Pagnocca (UNESP) ao Laboratório de Bioprocessos e Produtos sustentáveis (LBIOS), sob coordenação do Prof. Silvio Silvério da Silva. A lista de leveduras e o código utilizado estão apresentados na Tabela 6.

Tabela 6 - Lista de espécies de leveduras utilizadas e seu respectivo código

\begin{tabular}{|c|c|}
\hline Levedura & Código \\
\hline Candida shehatae 22-BR-2AY & SSS01 \\
\hline Trichosporon mucoides CLM 21.1 & SSS02 \\
\hline Trichosporon mucoides CLM 41.1b & SSS03 \\
\hline Trichosporon moniliiforme CLM 51.2 ${ }^{\mathrm{a}}$ & SSS04 \\
\hline Issatchenkia occidentalis Y1'b & SSS05 \\
\hline Issatchenkia orientalis CCTCC M 206098 & SSS06 \\
\hline Candida sp. 1 UFMG-HMD 25.1 & SSS07 \\
\hline Issatchenkia orientalis & SSS08 \\
\hline Candida shehatae 20-CGB-8BY & SSS09 \\
\hline Pichia ofunaensis R.C.2 & SSS10 \\
\hline Trichosporon mucoides CLM 42.4 & SSS11 \\
\hline Candida guilhermondii FT20037 & SSS12 \\
\hline Candida shehatae UFMG HM 52.2 & SSS13 \\
\hline Spathaspora arborarie sp. & SSS14 \\
\hline Candida shehatae UFMG HM 60.1b & SSS15 \\
\hline Issatchenkia occidentalis Y1'a & SSS16 \\
\hline Candida shehatae 2-PT1-1BASP & SSS17 \\
\hline Pichia stipitis UFMG IMH 43.2 & SSS18 \\
\hline Issatchenkia occidentalis sp. & SSS19 \\
\hline Issatchenkia occidentalis CCTCC М 206097 & SSS20 \\
\hline Issatchenkia occidentalis M1 & SSS21 \\
\hline Spathaspora sp. 2 UFMG-HMD 23.2 & SSS22 \\
\hline Spathaspora sp. 1 UFMG-HMD 16.3 & SSS23 \\
\hline Kluyveromyces marxianus & SSS24 \\
\hline Saccharomyces cerevisiae 405 & SSS25 \\
\hline Spathaspora sp. 3 UFMG-HMD 19.3 & SSS26 \\
\hline Spathaspora sp. 1 UFMG-HMD 16.2 & SSS27 \\
\hline Candida shehatae 16-BR6-2AI & SSS28 \\
\hline Pichia stipitis NRRL-Y7124 & SSS29 \\
\hline Trichosporon mucoides CLM 48.1b & SSS30 \\
\hline Issatchenkia occidentalis Y3' & SSS31 \\
\hline
\end{tabular}

Continua 
Conclusão

\begin{tabular}{ll}
\hline Levedura & Código \\
\hline Candida utilis UFMG-RVC-4.36 & SSS32 \\
Aureobasidium sp. LB 83 & SSS33 \\
Aureobasidium sp. LB 15.2 & SSS34 \\
Pichia kudriavzevii Sap 55 & SSS37 \\
Pichia kudriavzevii Sap 60 & SSS38 \\
Pichia kudriavzevii SBd 1-2 & SSS39 \\
\hline
\end{tabular}

Fonte: Arquivo pessoal.

\subsubsection{Manutenção das leveduras}

As leveduras foram mantidas em placas contendo o meio YMA (extrato de levedura, malte e ágar) composto por: glicose $1,0 \%$, extrato de malte $0,3 \%$, extrato de levedura $0,3 \%$, peptona $0,5 \%$, ágar $2 \%$. O meio foi esterilizado em autoclave a $121{ }^{\circ} \mathrm{C}$ por $15 \mathrm{~min}$. Os repiques em meio YMA sólidos foram realizados em capela asséptica e mantidos em estufa a $30 \pm 2{ }^{\circ} \mathrm{C}$. Após o crescimento e avaliação visual das colônias, estas foram transferidas para tubos com ágar YMA inclinado e após 72 h cobertos com óleo mineral ou glicerol estéril. Os tubos foram mantidos refrigerados a $4{ }^{\circ} \mathrm{C}$ e utilizados para preparo do inóculo. Os repiques das leveduras para novas placas e tubos foram desenvolvidos periodicamente em intervalos de três meses.

\subsection{Identificação das leveduras produtoras de biossurfactantes}

\subsubsection{Reativação das leveduras e fermentação submersa}

Uma alçada das leveduras estocadas foi utilizada para reativação das mesmas em meio Kitamoto $\left(\mathrm{KH}_{2} \mathrm{PO}_{4}\right.$ 0,2 \%, extrato de levedura $1,0 \%, \mathrm{NaNO}_{3} 2,0 \%$ e $\mathrm{MgSO}_{4} .7 \mathrm{H}_{2} \mathrm{O}$ 0,2 \% e 4,0 $\%$ de glicose como fonte de carbono) em tubos com rosca de $10 \mathrm{~mL}$ contendo $2 \mathrm{~mL}$ de meio de cultivo a uma agitação de $200 \mathrm{rpm}$ a $30{ }^{\circ} \mathrm{C}$ por $48 \mathrm{~h}$.

O cultivo reativado foi utilizado como pré-inóculo para as fermentações realizadas em duplicata, também em meio Kitamoto, utilizando frascos Erlenmeyer de $50 \mathrm{~mL}$ contendo $20 \mathrm{~mL}$ de meio a uma agitação de $200 \mathrm{rpm}$ por 72 h. As amostras foram então centrifugadas a $2000 \times$ g por 10 min para separação das células e do sobrenadante, o qual foi utilizado na realização dos testes de identificação da produção de biossurfactantes. 
4.2.2 Testes de identificação da produção de biossurfactantes

Para a identificação das leveduras produtoras de biossurfactantes foram realizados os testes de atividade hemolítica (item 4.12.1) e escorrimento da gota (item 4.12.2), utilizando uma alçada das leveduras após a ativação. Os testes de colapso da gota (item 4.12.3), espalhamento da gota (item 4.12.4) e índice de emulsificação (item 4.12.5) foram realizados utilizando o sobrenadante da fermentação submersa. As leveduras que apresentaram melhores resultados nestes testes foram utilizadas para testes seguintes da produção de biossurfactante por FES.

\subsection{Seleção da levedura com maior potencial para produção de biossurfactantes por fermentação em estado sólido (FES)}

Nesta etapa foram testadas aquelas leveduras que foram identificadas como produtoras de biossurfactantes por apresentarem resultados positivos nos testes descritos no ítem 4.2.2. Estas leveduras foram cultivadas por fermentação em estado sólido, como descrito a seguir.

\subsubsection{Preparo do inóculo}

O pré-inóculo foi preparado em frascos Erlenmeyer de $50 \mathrm{~mL}$ contendo $20 \mathrm{~mL}$ do meio Kitamoto, inoculados com uma alçada das leveduras identificadas como produtoras de biossurfactantes e incubados, em agitador orbital, a $30{ }^{\circ} \mathrm{C}$ sob agitação de $200 \mathrm{rpm}$ por $24 \mathrm{~h}$.

Foi feito um controle da assepsia do meio de cultivo incubando um frasco Erlenmeyer com $20 \mathrm{~mL}$ do meio nas mesmas condições, porém sem inoculação de células. A concentração celular do pré-inóculo foi obtida por contagem em Câmara de Agasse-Lafont-R (ítem 4.12.6).

\subsubsection{Preparo dos cultivos para a FES}

Os ensaios para fermentação em estado sólido (FES) foram realizados em frascos Erlenmeyer de $50 \mathrm{~mL}$, contendo $2 \mathrm{~g}$ de bagaço de cana-de-açúcar (substrato sólido seco em estufa a $60^{\circ} \mathrm{C}$ por $\left.24 \mathrm{~h}\right)$. O bagaço utilizado foi padronizado à granulometria entre 14 e 20 mesh (padrão Tyler), caracterizado (item 4.12.7) e o teor de açúcares solúveis analisado (item 4.12.8). Não foi realizada lavagem do bagaço de cana-de-açúcar para a sua utilização na fermentação em estado sólido. 
Os frascos Erlenmeyer contendo $2 \mathrm{~g}$ de bagaço (base seca) foram esterilizados a $121{ }^{\circ} \mathrm{C}$ por 15 minutos, resfriados e inoculados com $10 \mathrm{~mL}$ de solução umedecedora. Esse volume de solução umedecedora adicionado foi calculado para se atingir a máxima capacidade absortiva do bagaço, determinada previamente (ítem 4.12.9). Conforme as condições de ensaio estabelecidas, a solução umedecedora foi constituída de $9 \mathrm{~mL}$ de meio Kitamoto estéril adicionado de $1 \mathrm{~mL}$ de solução de células concentradas ( 1 x $10^{7}$ células $/ \mathrm{mL}$ ), para se obter uma concentração inicial de células 1 x $10^{6}$ células/mL na fermentação. A concentração celular foi padronizada de acordo com o valor encontrado na contagem em Câmara de Agasse-Lafont-R (item 4.12.6), pela centrifugação $(2000 \times \mathrm{g}$ por $10 \mathrm{~min})$, descarte de sobrenadante e ressuspensão em volume adequado de meio Kitamoto esterilizado para se atingir a concentração celular adequada.

Para que todo o líquido da solução umedecedora adicionada fosse absorvido pelo bagaço de forma mais uniforme foi feita uma homogeneização utilizando hastes estéreis. Os frascos inoculados foram então incubados em uma estufa mantida a $30 \pm 2{ }^{\circ} \mathrm{C}$, sob umidade de $80 \%$ por um período de $168 \mathrm{~h}$. O cultivo foi feito em duplicata e foi também preparado um cultivo controle sem inóculo (10 mL de meio Kitamoto estéril como solução umedecedora) mantidos nas mesmas condições de fermentação.

Devido à dificuldade de se retirar uma amostra representativa e homogênea nesse tipo de cultivo, foram preparados três frascos (triplicata) para cada ponto a ser analisado, sendo cada frasco considerado uma amostra. Os frascos foram incubados em uma estufa mantida a $30 \pm 2$ ${ }^{\circ} \mathrm{C}$, sob umidade de $80 \%$ por um período de 7 dias (168 h), sendo que a cada $24 \mathrm{~h}$ foram retirados os três frascos para as análises.

\subsubsection{Extração e análise da produção de biossurfactante}

Os cultivos foram interrompidos após o tempo de fermentação e, para a extração dos biossurfactantes produzidos, adicionou-se $20 \mathrm{~mL}$ de água destilada estéril em cada frasco Erlenmeyer de $50 \mathrm{~mL}$, deixando-os sob agitação em agitador rotatório a $200 \mathrm{rpm}$ a $30{ }^{\circ} \mathrm{C}$ por 1 h. Na seqüência, a mistura foi filtrada em gaze e prensada manualmente.

Os extratos resultantes foram centrifugados a $2000 \times$ g por $10 \mathrm{~min}$, e os sobrenadantes obtidos utilizados para os testes de espalhamento da gota (ítem 4.12.4) e índice de emulsificação (ítem 4.12.5). 


\subsection{Avaliação da produção de enzimas lignocelulolíticas pela levedura selecionada para a produção de biossurfactante por FES}

Foram avaliadas qualitativamente a produção das enzimas celulases (item 4.12.10), xilanases (item 4.12.11) e ligninases (item 4.12.12), para analisar a capacidade da levedura de utilização da biomassa lignocelulósica como substrato e fonte de carbono.

Após os testes qualitativos, foram testadas quantitativamente as atividades enzimáticas utilizando-se o extrato bruto da FES. Testou-se as atividades de celulases totais (FPA) (item 4.12.13) e xilanases (item 4.12.14) a cada 24 h até 168 h (tempo total da fermentação para produção de biossurfactante). $\mathrm{O}$ procedimento de amostragem foi realizado conforme descrito no ítem 4.3.2.

\subsection{Estudo de condições para o processo de produção de biossurfactantes pela levedura selecionada}

4.5.1 Avaliação da influência de diferentes fontes de carbono para a produção de biossurfactantes pela levedura selecionada

Foi avaliada a influência de diferentes fontes de carbono (glicose, xilose, manose, arabinose e sacarose) na produção de biossurfactantes pela levedura selecionada. Para tanto, foram realizados cultivos-teste em fermentação submersa e em estado sólido, utilizando um meio de cultivo base já descrito na literatura para a produção de biossurfactantes por este microorganismo, composto por peptona $0,6 \mathrm{~g} / \mathrm{L}$, extrato de levedura $0,4 \mathrm{~g} / \mathrm{L}, \mathrm{K}_{2} \mathrm{HPO}_{4}$ 5,0 g/L, $\mathrm{MgSO}_{4} .7 \mathrm{H}_{2} \mathrm{O}$ 0,4 g/L, $\mathrm{NaCl}$ 1,0 g/L e de fonte de carbono $50 \mathrm{~g} / \mathrm{L}$ (MANITCHOTPISIT et al., 2011).

O inóculo foi preparado em meio composto por glicose como fonte de carbono no meio com composição descrita acima, autoclavado a 0,5 atm por 20 min e incubados a $200 \mathrm{rpm}$ a 28 $\pm 2{ }^{\circ} \mathrm{C}$ por $48 \mathrm{~h}$. A padronização do inóculo foi feita utilizando-se a câmara de Agasse-Lafont$\mathrm{R}$ (ítem 4.12.6) para a contagem de células e ajustada para uma concentração inicial de $10^{6}$ células/mL.

As fermentações submersas foram realizadas em triplicatas em frascos Erlenmeyer de $250 \mathrm{~mL}$ contendo $80 \mathrm{~mL}$ de meio. Foram utilizadas como fontes de carbono separadamente glicose, sacarose, xilose, manose e arabinose na concentração de $50 \mathrm{~g} / \mathrm{L}$ e como fonte de sais e nitrogênio foi utilizada mesma composição do inóculo. Os frascos foram incubados a 150 rpm 
a $28{ }^{\circ} \mathrm{C}$ por 7 dias $(168 \mathrm{~h})$, sendo que a cada $24 \mathrm{~h}$ foram retiradas amostras para as análises. Avaliou-se a morfologia celular por microscopia (item 4.12.15), o crescimento celular por contagem em câmara Agasse-Lafont-R (item 4.12.6), o valor de pH (item 4.12.16), o consumo da fonte de carbono em HPLC (item 4.12.17), e o espalhamento da gota, sendo cálculada a produtividade em tensoatividade $\left(\mathrm{Q}_{\mathrm{ta}}\right)$ (item 4.12.4).

As fermentações em estado sólido foram realizadas em triplicata em frascos Erlenmeyer $50 \mathrm{~mL}$, contendo $2 \mathrm{~g}$ de bagaço de cana-de-açúcar esterilizados a $121^{\circ} \mathrm{C}$ por $15 \mathrm{~min}$, resfriados e inoculados com $10 \mathrm{~mL}$ de solução umedecedora, sendo $9 \mathrm{~mL}$ do meio com mesma composição do utilizado para a fermentação submersa (variando a fonte de carbono: glicose, sacarose, xilose, manose e arabinose) estéril, adicionado de $1 \mathrm{~mL}$ de solução de células concentradas ( $1 \times 10^{7}$ células $/ \mathrm{mL}$ ). Os frascos foram incubados em uma estufa mantida a $28 \pm$ $2{ }^{\circ} \mathrm{C}$, sob umidade relativa de $80 \%$ por um período de 7 dias $(168 \mathrm{~h})$. Após esse tempo, os cultivos foram interrompidos e adicionou-se volume adequado (item 4.12.9) de água destilada estéril em cada frasco, os quais foram deixados sob agitação em agitador rotatório a $200 \mathrm{rpm}$ a $30{ }^{\circ} \mathrm{C}$ por 1 hora. Na seqüência, a mistura foi filtrada em gaze e prensada manualmente. $\mathrm{O}$ extrato obtido foi utilizado para a avaliação da produção de biossurfactantes pelo teste de espalhamento da gota (item 4.12.4). Foram preparados cinco cultivos controle, sendo um para cada fonte de carbono (10 mL de meio estéril como solução umedecedora) mantidos nas mesmas condições de fermentação.

A análise estatística realizada foi o teste de Tukey a $95 \%$ de confiança, objetivando avaliar a diferença entre as médias encontradas para os resultados do teste de espalhamento da gota dividido pelo tempo de fermentação. O Software SISVAR 5.3 foi utilizado para análise (FERREIRA, 2011).

\subsubsection{Avaliação do uso de indutores na produção de biossurfactantes pela} levedura selecionada.

A avaliação da influência da adição dos indutores óleo de soja e glicerol para a produção de biossurfactantes pela levedura que apresentou melhores resultados nos testes iniciais foi realizada por meio de testes preliminares utilizando como fonte de carbono no meio de cultura somente sacarose $50 \mathrm{~g} / \mathrm{L}$ como condição controle, sacarose $50 \mathrm{~g} / \mathrm{L}$ adicionado de indutor glicerol $3 \%(\mathrm{v} / \mathrm{v})$, sacarose $50 \mathrm{~g} / \mathrm{L}$ adicionado de indutor óleo de soja $5 \%(\mathrm{v} / \mathrm{v})$ e sacarose 50 $\mathrm{g} / \mathrm{L}$ adicionado dos indutores glicerol 3\% (v/v) e óleo de soja 5\% (v/v). As fermentações foram 
realizadas em triplicata. Para cada condição foram analisados os valores de $\mathrm{pH}$ (item 4.12.16), concentração celular (item 4.12.6), tensoatividade (item 4.12.4) e produtividade em tensoatividade $(\mathrm{cm} / \mathrm{h})$ (dada pela razão entre o resultado de tensoatividade pelo tempo de fermentação) por 168 h, sendo retiradas amostras a cada 24 h. Para avaliar se houve diferença significativa entre os maiores valores de tensoatividade e produtividade em tensoatividade para cada condição, utilizou-se o teste de Tukey a 95\% de confiança. Para tanto, o Software SISVAR 5.3 foi utilizado (FERREIRA, 2011).

Para avaliar se a adição de concentrações maiores ou menores de glicerol e óleo de soja resultariam em efeitos significativos na produção de biossurfactantes, foi realizado um planejamento fatorial completo $2^{2}$ com triplicata no ponto central. As variáveis independentes estudadas foram concentração de óleo de soja ( 0 a $10 \%$ v/v) e concentração de glicerol (0 a 6 $\% \mathrm{v} / \mathrm{v})$. As variáveis resposta utilizadas foram a máxima tensoatividade $(\mathrm{cm})(\mathrm{Ta})$, determinada por meio do teste do espalhamento da gota e produtividade em tensoatividade $(\mathrm{cm} / \mathrm{h})\left(\mathrm{Q}_{\mathrm{Ta}}\right)$, dada pela razão entre o resultado de maior tensoatividade pelo tempo de fermentação (item 4.12.4). A matriz do planejamento fatorial $2^{2}$ completo é apresentada na Tabela 7. Os testes foram conduzidos em fermentação submersa devido à menor complexidade desse processo quanto à homogeinização e retirada de amostras quando comparado à FES.

Tabela 7 - Matriz do Planejamento Fatorial $2^{2}$ completo com triplicata no ponto central com valores codificados das variáveis independentes concentração de glicerol (\% v/v) e concentração de óleo de soja (\% v/v) utilizadas na produção de biossurfactantes por levedura

\begin{tabular}{ccccc}
\hline Ensaio & \multicolumn{2}{c}{ Valores codificados } & \multicolumn{2}{c}{ Valores reais $(\% \mathbf{v} / \mathbf{v})$} \\
\cline { 2 - 5 } & $\mathrm{x}_{1}$ & $\mathrm{x}_{2}$ & $\mathrm{x}_{1}$ & $\mathrm{x}_{2}$ \\
\hline $\mathbf{1}$ & -1 & -1 & $\mathbf{0}$ & $\mathbf{0}$ \\
$\mathbf{2}$ & +1 & -1 & $\mathbf{6}$ & $\mathbf{0}$ \\
$\mathbf{3}$ & -1 & +1 & $\mathbf{0}$ & $\mathbf{1 0}$ \\
$\mathbf{4}$ & +1 & +1 & $\mathbf{6}$ & $\mathbf{1 0}$ \\
$\mathbf{5}$ & 0 & 0 & $\mathbf{3}$ & $\mathbf{5}$ \\
$\mathbf{6}$ & 0 & 0 & $\mathbf{3}$ & $\mathbf{5}$ \\
$\mathbf{7}$ & 0 & 0 & $\mathbf{3}$ & $\mathbf{5}$ \\
\hline
\end{tabular}

$\mathrm{x}_{1}$ :Concentração de glicerol; $\mathrm{x}_{2}$ :Concentração de óleo de soja. Fonte: Arquivo pessoal.

A escolha dos pontos centrais das variáveis foi baseada em dados encontrados na literatura (MEIRA, 2007; CAMILIOS NETO, 2010; CAMILIOS NETO et al., 2011). Os 
resultados foram avaliados estatisticamente utilizando-se o programa STATISTICA for Windows (StatSoft, Inc. V.5 Tulsa, OK, USA). Os resultados foram expressos em tabelas de estimativas de efeitos (gráfico de Pareto).

4.5.3. Estudo da influência da concentração da fonte de carbono e da aeração na produção de biossurfactantes pela levedura selecionada em fermentação submersa

Para avaliar a influência da concentração da fonte de carbono selecionada (sacarose) e da aeração no processo de produção de biossurfactantes por Aureobasidium pullulans LB 83, realizou-se um planejamento de experimentos $2^{2}$ com delineamento composto rotacional (DCCR) com três repetições no ponto central. Foram investigadas a influência da concentração de sacarose (de 20 a $80 \mathrm{~g} / \mathrm{L}$ ) e da aeração (vvm) (de 0,1 a 1,1 min ${ }^{-1}$ ) (Tabela 8), e suas interações no processo de produção de biossurfactante. As variáveis resposta utilizadas foram a maior tensoatividade $(\mathrm{cm})(\mathrm{Ta})$, avaliada pelo teste do espalhamento da gota (item 4.12.4), e a produtividade em tensoatividade $\left(\mathrm{Q}_{\mathrm{Ta}}\right)$ (dada pela razão entre o resultado de maior tensoatividade pelo tempo de fermentação). A análise dos testes estatísticos foi realizada com o software STATISTICA para Windows (StatSoft, Inc. V.5 Tulsa, OK, EUA).

Tabela 8 - Valores codificados e valores reais das variáveis independentes concentração de sacarose (g/L) e aeração $\left(\min ^{-1}\right)$ no processo de produção de biossurfactante por Aureobasidium pullulans LB 83

\section{Variáveis independentes}

\begin{tabular}{ccc}
\cline { 2 - 3 } Níveis & Concentração de sacarose $(\mathbf{g} / \mathbf{L})$ & aeração $\left(\mathbf{m i n}^{\mathbf{- 1}}\right)$ \\
\hline $\mathbf{- 1}$ & 20 & 0,1 \\
\hline $\mathbf{0}$ & 50 & 0,6 \\
\hline $\mathbf{+ 1}$ & 80 & 1,1 \\
\hline
\end{tabular}

Fonte: Arquivo pessoal.

As fermentações para avaliação destes fatores foram realizadas em biorreator BIOSTAT BPlus de 5 L (Sartorius AG, Alemanha) contendo 3 L de meio de cultivo (Figura 7) composto por peptona 0,6 g/L, extrato de levedura 0,4 g/L, $\mathrm{K}_{2} \mathrm{HPO}_{4} 5,0 \mathrm{~g} / \mathrm{L}, \mathrm{MgSO}_{4} .7 \mathrm{H}_{2} \mathrm{O}$ 0,4 g/L, NaCl $1,0 \mathrm{~g} / \mathrm{L}$ e sacarose (concentração de acordo com o desenho experimental) (MANITCHOTPISIT et al., 2011). Para agitação, utilizou-se impelidor Rushton duplo a 300 rpm. A temperatura (28 $\left.{ }^{\circ} \mathrm{C}\right), \mathrm{pH}(5,5)$, velocidade de agitação (300 rpm) e aeração (de acordo com o desenho 
experimental) foram monitorados e controlados automaticamente. A aeração foi mantida constante durante o processo e a pressão parcial de oxigênio $\left(\mathrm{pO}_{2}\right)$ foi medida ao longo da fermentação por meio de eletrodo de oxigênio (Hamilton, OXYFERM FDA 325, Suíça). O valor do $\mathrm{pH}$ foi mantido a 5,5 \pm 0,5 pela adição de $\mathrm{NaOH} 4 \%(\mathrm{~m} / \mathrm{m})$ ou $\mathrm{HCl} 4 \%(\mathrm{~m} / \mathrm{m})$. Um inóculo de $6 \%$ (v/v) foi utilizado em todas as fermentações (concentração inicial de células de aproximadamente $1 \times 10^{6} \mathrm{cel} / \mathrm{mL}$ ). Foram retiradas amostras regularmente a cada $24 \mathrm{~h}$ até 168 h para análise de açúcares sacarose, glicose e frutose (item 4.12.17), concentração celular (4.12.6) e tensoatividade (item 4.12.4)

Figura 7 - Biorreator BIOSTAT BPlus 5L (Sartorius AG, Alemanha)
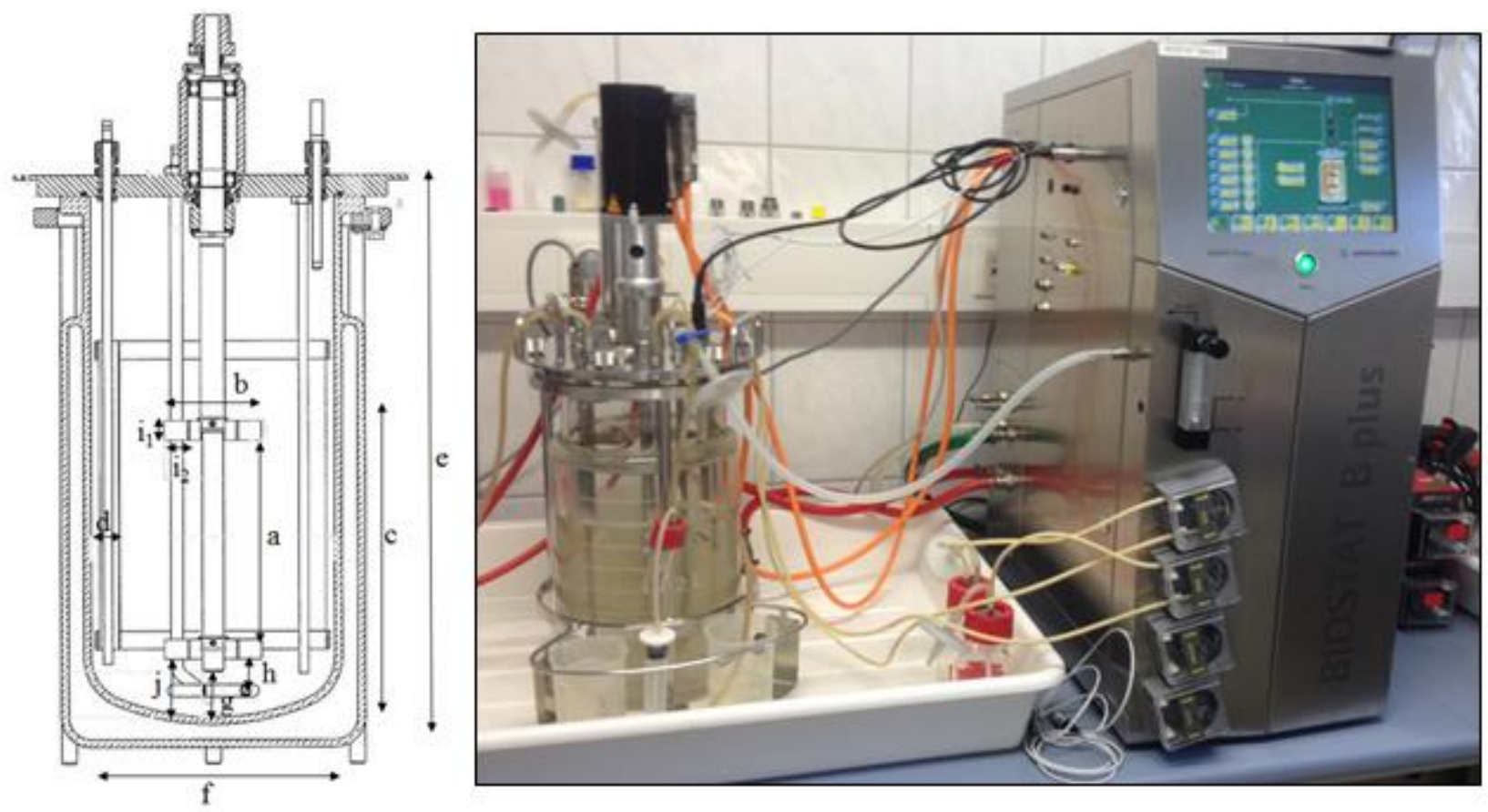

a: distância entre os agitadores $(8 \mathrm{~cm})$; b: diâmetro entre as paleta $(6,0 \mathrm{~cm})$; $\mathbf{c}$ : altura do líquido $(15 \mathrm{~cm})$; d: largura de cada chicana $(1,2 \mathrm{~cm}), 4$ chicanas; e: altura total do vaso $(35 \mathrm{~cm})$; f: diâmetro total do vaso $(16 \mathrm{~cm}) ; \mathbf{g}$ : distância ponta do agitador ao fundo do vaso $(3,0 \mathrm{~cm}) ; \mathbf{h}$ : distância do aerador ao agitagor $(3,0 \mathrm{~cm}) ; \mathbf{i}_{1}$ e $\mathbf{i}_{2}$ : dimensões da paleta do agitador $(1,5 \times 1,5 \mathrm{~cm})(6$ paletas por agitador $) ; \mathbf{j}$ : distância entre paletas ao fundo do vaso $(3,5 \mathrm{~cm})$. Fonte: Arquivo pessoal.

Esses experimentos foram realizados no Leibniz Institute for Agricultural Engineering and Bioeconomy em Potsdam-Bornim, Alemanha. 


\subsection{Avaliação da correlação entre tensoatividade e concentração do biossurfactante}

A correlação entre tensoatividade avaliada pelo teste de espalhamento da gota (item 4.12.4) e concentração de biossurfactante (4.12.18) foi obtida por meio da construção de uma curva padrão utilizando cinco diluições diferentes $(0,2 ; 0,6 ; 0,9 ; 1,0$ e $1,5 \mathrm{~g} / \mathrm{L})$ do biossurfactante extraído da fermentação. A extração foi realizada de acordo com Manitchotpisit et al. (2011) (item 4.12.19). O teste de espalhamento da gota foi realizado utilizando as mesmas soluções com diferentes concentrações de biossurfactante. Os resultados obtidos foram utilizados para a construção do gráfico relacionando as diferentes concentrações do biossurfactante $(\mathrm{g} / \mathrm{L})$ pela tensoatividade $(\mathrm{cm})$ obtida.

\subsection{Estudo das variáveis para a produção de biossurfactantes pela levedura} selecionada em processo de fermentação em estado sólido

4.7.1 Influência das variáveis tamanho médio das partículas do bagaço de canade-açúcar, volume de meio inicial, concentração celular e volume de água para extração

Para a determinação da concentração de biossurfactante produzida em FES utilizando a levedura Aureobasidium pullulans, utilizou-se o planejamento fatorial completo $2^{4}$ com cinco repetições no ponto central, avaliando-se as variáveis independentes: tamanho médio das partículas do bagaço de cana-de-açúcar $(1,18 \mathrm{~mm}, 0,89 \mathrm{~mm}$ e 0,6 mm), volume de meio inicial utilizado para umedecer o bagaço $(8 \mathrm{~mL}, 10 \mathrm{~mL}$ e $12 \mathrm{~mL})$, concentração celular do pré-inóculo ( $10^{5}$ células $/ \mathrm{mL} ; 5,05 \times 10^{6}$ células $/ \mathrm{mL}$ e $10^{7}$ células $\left./ \mathrm{mL}\right)$ e volume de água destilada utilizada para a extração $(15 \mathrm{~mL}, 20 \mathrm{~mL}$ e $25 \mathrm{~mL})$. Os testes foram realizados em freascos Erlenmeyer de $25 \mathrm{~mL}$ contendo $2 \mathrm{~g}$ de bagaço de cana-de-açúcar.

A variável resposta para este planejamento de experimentos foi caracterizada como a concentração de biossurfactante produzida na FES (item 4.12.18). Os níveis das variáveis estudadas encontram-se apresentadas na Tabela 9. 
Tabela 9 - Níveis codificados e valores reais do planejamento de experimentos $2^{4}$ para variáveis independentes: tamanho médio das partículas do bagaço, concentração do inóculo em células $/ \mathrm{mL}$, volume de meio inicial e volume de água para a extração, no processo de produção de biossurfactante em FES da pela levedura selecionada em bagaço de cana-de-açúcar

\begin{tabular}{rccc}
\hline Variáveis independentes & $\mathbf{( + 1 )}$ & $\mathbf{0}$ & $\mathbf{( - 1 )}$ \\
\hline (A) Tamanho médio das partículas do bagaço $(\mathrm{mm})$ & 1,18 & 0,89 & 0,6 \\
(B) Volume de meio inicial $(\mathrm{mL})$ & 8 & 10 & 12 \\
(C) Concentração do inóculo (cél/mL) & $10^{5}$ & $5,05 \times 10^{6}$ & $10^{7}$ \\
(D) Volume para extração $(\mathrm{mL})$ & 15 & 20 & 25 \\
\hline
\end{tabular}

Fonte: Arquivo pessoal.

A análise da variável resposta, concentração de biossurfactante, foi realizada utilizandose o programa STATISTICA for Windows (StatSoft, Inc. V.5 Tulsa, OK, USA). Os resultados foram expressos em gráficos de Pareto.

\subsection{Comparação da produção de biossurfactantes em processo de fermentação submersa e fermentação em estado sólido pela levedura selecionada e avaliação da metodologia de extração}

Para avaliar qual configuração de processo fermentativo apresentou maior rendimento na produção de biossurfactantes pela levedura selecionada, foram realizadas fermentações submersas em triplicata em frascos Erlenmeyer de $250 \mathrm{~mL}$, contendo $80 \mathrm{~mL}$ de meio de acordo com as melhores condições estabelecidas para a FS (item 4.5). Os frascos foram incubados a $28{ }^{\circ} \mathrm{C}$ e $200 \mathrm{rpm}$ por $168 \mathrm{~h}$. Após esse tempo, o biossurfactante foi extraído (item 4.12.19) e a produção de biossurfactante foi avaliada or meio da determinação da concentração de biossurfactante produzido por volume de meio (item 4.12.18). Paralelamente também foram realizadas em triplicata fermentações em estado sólido em frascos Erlenmeyer de $125 \mathrm{~mL}$ contendo $5 \mathrm{~g}$ de bagaço de cana-de-açúcar. A granulometria do bagaço, volume de solução umedecedora e concentração de inóculo foram utilizadas de acordo com as melhores condições estabelecidas para a FES (item 4.6). Os frascos foram incubados a $28{ }^{\circ} \mathrm{C}$ em umidade relativa de $80 \%$ por 168 h. Após esse tempo o biossurfactante foi extraído por diferentes metodologias (item 4.12.20), e a produção de biossurfactante foi avaliada por meio da determinação da concentração de biossurfactante produzido por volume de meio (item 4.12.18). 
Foi realizada a análise estatística por meio do teste de Tukey a 95\% de confiança, objetivando avaliar se houve diferença entre as médias encontradas para os resultados concentração de biossurfactante produzido por volume de meio na FS e na FES. Também foi avaliado se houve diferença estatística entre os diferentes métodos de estração utilizados para a FES. O Software SISVAR 5.3 foi utilizado para análise (FERREIRA, 2011).

\subsection{Caracterização bioquímica da molécula de biossurfactante produzida pela} levedura selecionada

O biossurfactante produzido foi extraído utilizando a metodologia de extração por solvente (ítem 4.12.19). O biossurfactante extraído foi ressuspendido em água e, em meio aquoso foi realizada a hidrólise do biossurfactante (item 4.12.21). Utilizando este biossurfactante hidrolisado foram realizadas análises de proteínas (item 4.12.22), lipídeos (item 4.12.23), açúcares redutores (item 4.12.24), outros açúcares e polióis (item 4.12.25).

\subsection{Avaliação da atividade tensoativa do biossurfactante produzido em relação à surfactantes sintéticos}

Para comparar o desempenho do biossurfactante obtido com relação a surfactantes sintéticos comercialmente disponíveis, o teste de espalhamento de gota (4.12.4) foi realizado utilizando os surfactantes sintéticos Tween 20, Tween 80 e dodecilsulfato de sódio $10 \mathrm{~g} / \mathrm{L}$. O diâmetro $(\mathrm{cm})$ da abertura do halo na superfície do óleo foi medido e comparado com o resultado obtido pelo biossurfactante produzido na concentração de 1,5 g/L. Essa concentração de biossurfactante foi utilizada por estar na faixa linear da curva padrão construída relacionando o resultado de tensoatividade obtido no teste de espalhamento da gota e a concentração do biossurfactante (item 4.6.)

\subsection{Avaliação da utilização do biossurfactante em processo de biorremediação}

Para avaliar o potencial da utilização do biossurfactante produzido em processo de biorremediação, foi analisada a sua capacidade de recuperação de petróleo cru, de acordo com a metodologia proposta por Pereira e colaboradores (2013) (item 4.12.27). Neste teste, a ação do biossurfactante $(0,01 \%)$ na remoção de petróleo foi comparada com a ação do surfactante 
sintético dodecil sulfato de sódio (SDS) $(0,01 \%$ e $0,05 \% \mathrm{~m} / \mathrm{v})$ e amostra controle, utilizando água desmineralizada. $O$ teste foi realizado em triplicata para cada condição avaliada.

\subsection{Métodos analíticos}

\subsubsection{Atividade hemolítica}

Inocularam-se as leveduras em placas com ágar Kitamoto, suplementado com 5\% de sangue desfibrinado. Em seguida, as placas inoculadas foram incubadas em estufa a $28{ }^{\circ} \mathrm{C}$ por um período de $72 \mathrm{~h}$. Após o tempo de incubação, foi observada a presença ou ausência de alfa, beta ou gama hemólise. A atividade hemolítica é correlacionada com a formação de biossurfactante, segundo Carrillo et al. (1996). O teste foi feito em duplicata.

\subsubsection{Escorrimento da gota}

Uma alçada de células de cada levedura testada foi misturada a uma gota da solução de $\mathrm{NaCl}$ 0,9 \% na extremidade de uma lâmina de vidro limpa. A lâmina foi inclinada e a presença de biossurfactante na amostra foi confirmada com o escorrimento da gota. Um controle contendo apenas a gota de $\mathrm{NaCl}$ 0,9\% foi utilizado para comparação (PEERSON; MOLIN, 1987). O teste foi feito em triplicata.

\subsubsection{Colapso da gota}

Uma placa contendo pequenas cavidades foi coberta com óleo de motor automotivo e deixada em repouso por 15 min para formação de uma camada uniforme de óleo. Uma alíquota de $5 \mu \mathrm{L}$ do sobrenadante obtido para cada levedura (item 4.2.1) foi adicionada no centro da cavidade revestida. A produção de biossurfactante foi detectada pelo colapso da gota dentro do tempo de um minuto (BODOUR; MAIER, 1998). O controle foi feito utilizando $5 \mu \mathrm{L}$ de meio de cultivo não inoculado. O diâmetro do halo produzido foi medido para uma avaliação semiquantitativa da produção de biossurfactante. $O$ teste foi realizado em triplicata. 


\subsubsection{Espalhamento da gota}

Uma placa de Petri foi preenchida com $50 \mathrm{~mL}$ de água destilada e adicionada de 20 $\mu \mathrm{L}$ de óleo de motor automotivo e $10 \mu \mathrm{L}$ do sobrenadante obtido para cada levedura (item 4.2.1). A presença de biossurfactante foi confirmada com o espalhamento da gota abrindo um halo sobre o óleo (MORIKAWA et. al., 2000). O controle foi feito utilizando $10 \mu \mathrm{L}$ de meio de cultivo não inoculado. O teste foi realizado em triplicata.

O teste de espalhamento da gota também foi utilizado para a medida da atividade tensoativa do biossurfactante produzido, por meio da medida do diâmetro da zona de abertura do halo $(\mathrm{cm})$. O valor desse diâmetro está relacionado com a concentração de biossurfactante presente no meio. O valor de produtividade em tensoatividade $\left(\mathrm{Q}_{\mathrm{Ta}}\right)(\mathrm{cm} / \mathrm{h})$ foi calculado pela relação entre a máxima tensoatividade $(\mathrm{cm})$ e tempo de fermentação $(\mathrm{h})$.

\subsection{5 Índice de emulsificação (IE)}

Foi adicionado $1 \mathrm{~mL}$ do do sobrenadante obtido para cada levedura (item 4.2.1) a $1 \mathrm{~mL}$ de querosene e a mistura foi agitada vigorosamente em um vórtex por 2 min a fim de obter uma emulsão. O índice de emulsificação foi calculado de acordo com a equação 1:

$$
\operatorname{IE}(\%)=\left(\frac{h_{\text {emulsão }}}{h_{\text {total }}}\right) \times 100
$$

Onde:

IE = Índice de emulsificação; $h_{\text {emulsão }}$ altura da emulsão; $h_{\text {emulsão }}=$ altura total da mistura

A presença do biossurfactante foi avaliada pelo índice calculado e sua estabilidade avaliada por um período de 7 dias (ítem 4.12.5.1) (FRANCY et al., 1991). O controle foi feito utilizando $1 \mathrm{~mL}$ de meio de cultivo não inoculado. $\mathrm{O}$ teste foi realizado em triplicata. Também foi observado o aspecto da emulsão formada.

\subsubsection{Estabilidade da emulsão (EE)}

O índice de emulsificação foi medido de 24 em 24 h por uma semana para avaliar sua estabilidade. O cálculo da estabilidade foi realizado após 7 dias (168h) e está apresentado na equação 2: 


$$
E E(\%)=100-\left(\frac{E I_{24}-E I_{168}}{E I_{24}}\right) \times 100
$$

Onde:

$\mathrm{EE}=$ Estabilidade da emulsão; $\mathrm{EI}_{24}=$ Índice de emulsificação após $24 \mathrm{~h} ; \mathrm{EI}_{168}=$ Índice de emulsificação após $168 \mathrm{~h}$.

4.12.6 Determinação da concentração celular em câmara Agasse-Lafont-R e estimativa da concentração celular na FES

A concentração celular foi determinada pelo método da contagem de células em Câmera de Agasse-Lafont-R (Figura 8), com retículos de 0,0025 $\mathrm{mm}^{2}$ e profundidade de 0,100 mm.

Figura 8 - Esquema da câmara Agasse-Lafont-R

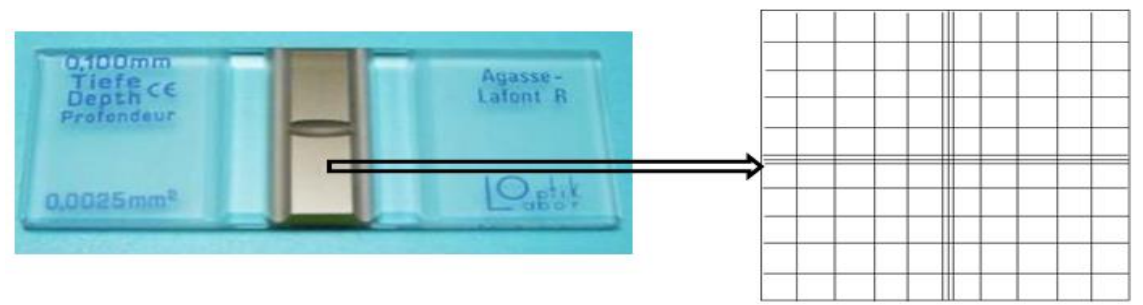

Fonte: Arquivo pessoal

Para a determinação da concentração celular (cel/mL) utilizou-se a contagem de 25 retículos e o cálculo foi feito de acordo com a equação a seguir:

$$
\mathrm{cel} / \mathrm{mL}=n \times F \times 1,6 \times 10^{5}
$$

Onde:

$\mathrm{n}=$ número de células contadas nos retículos; $\mathrm{F}$ = fator de diluição.

A estimativa da concentração celular durante a FES foi obtida pela concentração de células extraídas (determinadas por contagem na Câmara Agasse-Lafont no extrato da FES) somada à concentração de células retida no bagaço de cana-de-açúcar.

A concentração de células retidas no bagaço de cana-de-açúcar foi determinada pela diferença entre a concentração conhecida de células inoculada no bagaço $\left(1 \times 10^{6} \mathrm{cel} / \mathrm{mL}\right)$ e a concentração obtida após a extração (realizada logo após inoculação e homogeinização, sem tempo de incubação). O valor obtido $\left(5,52 \times 10^{5} \mathrm{cel} / \mathrm{mL}\right)$ foi adicionado à concentração celular extraída nas amostras de FES. 
4.12.7 Caracterização do bagaço de cana-de-açúcar utilizado na FES

O bagaço de cana-de-açúcar utilizado neste trabalho foi gentilmente cedido pela usina Costa Bioenergia (Umuarama - PR) e encontrava-se isento de qualquer pré-tratamento.

A metodologia utilizada para a determinação da composição química do bagaço foi realizada de acordo com National Renewable Energy Laboratory - NREL (SLUITER, et. al., 2012). Para tanto, inicialmente o material já seco foi triturado em moinho de facas para se obter partículas com tamanho médio entre 20 e 80 mesh, e a umidade foi determinada em balança com medidor de umidade de infra-vermelho (Termobalança Top-Ray, Tecnal com infravermelho a $100^{\circ} \mathrm{C}$, até massa constante). As amostras foram submetidas à extração alcoólica por $6 \mathrm{~h}$ seguida de extração aquosa também por $6 \mathrm{~h}$ em extrator Soxhlet para a retirada de extrativos que poderiam interferir em sua caracterização. $O$ teor de extraíveis foi estabelecido pela diferença das massas da amostra extraída e não extraída.

Todos os procedimentos da caracterização foram realizados utilizando a amostra livre de extrativos e em triplicata, levando com consideração nos cálculos sempre a massa da amostra em base seca. Para a hidrólise foram pesados $300 \pm 10,0 \mathrm{mg}$ de amostra em tubo de ensaio e foram adicionados 3,00 \pm 0,01 $\mathrm{mL}$ de ácido sulfúrico $\left(\mathrm{H}_{2} \mathrm{SO}_{4}\right)$ numa concentração $72 \%(\mathrm{~m} / \mathrm{m})$, homogeneizados rapidamente com o auxílio de um bastão de vidro. Os tubos então foram levados ao banho termostático a $30{ }^{\circ} \mathrm{C}$ por 60 minutos, sendo agitados com o bastão a cada 5 minutos.

Após o tempo em banho termostático, a amostra foi transferida quantitativamente para frascos Erlenmeyer de $250 \mathrm{~mL}$ com a adição de 84,0 mL água deionizada. Os frascos Erlenmeyer foram levados à autoclave a $121{ }^{\circ} \mathrm{C}$ por $1 \mathrm{~h}$ e em seguida foram deixados a temperatura ambiente. Após resfriamento a temperatura ambiente, a suspensão foi filtrada em cadinho de vidro com filtro poroso $\mathrm{n}^{\circ} 3$, previamente tarado, e transferida quantitativamente para um balão volumétrico, avolumado para $100 \mathrm{~mL}$ com agua destilada. A partir deste hidrolisado acido foi determinada a concentracao dos acucares monoméricos (glicose, xilose e arabinose) e de ácido acético solubilizados em solucao, os quais foram utilizados para o cálculo dos teores de celulose, hemicelulose, que pode ser desmembrada em xilana e arabinosil, grupos acetil e lignina solúvel presentes na amostra de biomassa analisada. 
4.12.7.1 Análises de lignina insolúvel

Após o resfriamento, a amostra foi filtrada nos filtros tarados em pesa-filtro. Água deionizada foi utilizada para remover quantitativamente todo remanescente sólido do frasco Erlenmeyer. O filtrado foi armazenado em balão volumétrico de $100 \mathrm{~mL}$ (que teve seu volume completo) e reservado para análises posteriores de carboidratos, grupo acetil e lignina solúvel. Após a filtração, os sólidos foram rinsados com $200 \mathrm{~mL}$ de água e os filtros foram colocados nos seus respectivos pesa-filtros com os resíduos insolúveis e levados à estufa a 105 ${ }^{\circ} \mathrm{C}$ até peso constante (aproximadamente $8 \mathrm{~h}$ ). Foram deixados em dessecador para resfriamento para que as pesagens fossem feitas com o material à temperatura ambiente. Após registrar a massa final da lignina insolúvel, os filtros foram transferidos para cadinhos (previamente pesados) e levados à mufla a $575{ }^{\circ} \mathrm{C}$ por $24 \pm 6 \mathrm{~h}$. Após resfriamento em dessecador, a massa de cinzas da lignina insolúvel foi pesada.

\subsubsection{Análises de lignina solúvel}

A análise de lignina solúvel foi feita no filtrado após hidrólise, em espectrofotômetro, com comprimento de onda de $205 \mathrm{~nm}$, utilizando cubeta de quartzo. Para o branco, foi utilizada solução de ácido sulfúrico $4 \%(\mathrm{~m} / \mathrm{m})$. As amostras (duplicata) foram diluídas 10 vezes, e para a diluição também foi utilizada a solução de ácido sulfúrico $4 \%(\mathrm{~m} / \mathrm{m})$.

\subsubsection{Análises de carboidratos e grupo acetil}

Para análise de carboidratos e grupo acetil foi utilizado o líquido obtido da hidrólise já filtrado. A amostra foi preparada em duplicata para análise em HPLC sendo filtradas em seppack C18 (Millipore). As análises foram feitas utilizando coluna Aminex HPX-87H, Biorad (300 x 7,8 mm) a $45^{\circ} \mathrm{C}$ utilizando como eluente solução de $\mathrm{H}_{2} \mathrm{SO}_{4}$ 0,001 $\mathrm{N}$ e um fluxo de 0,6 $\mathrm{mL} / \mathrm{min}$ e detecção por índice de refração RID 6A. Foram utilizados padrões de celobiose, glicose, xilose, arabinose e ácido acético.

\subsubsection{Análises de cinzas totais}

A biomassa livre de extrativos foi pesada em duplicata $(0,500 \mathrm{~g}$ em base seca) em cadinhos previamente tarados. Os cadinhos com a amostra foram levados à mufla a $575{ }^{\circ} \mathrm{C}$ por 
$24 \pm 6$ h. Após resfriamento em dessecador, os cadinhos foram novamente pesados e a massa de cinzas totais determinada.

4.12.8 Determinação dos açúcares solúveis residuais do bagaço de cana-deaçúcar

A análise de açúcares solúveis residuais do bagaço de cana-de-açúcar in natura utilizado na FES foi feita em duplicata. Para tanto, primeiramente se realizou a extração dos açúcares solúveis de acordo com a Figura 9. Os sobrenadantes resultantes da extração foram acondicionados no mesmo frasco analisado em duplicata quanto ao teor de açúcares totais pelo método Fenol-sulfúrico (DUBOIS, 1956). Neste método monossacarídeos, oligossacarísios, polissacarídios e seus derivados são convertidos a furfural, utilizando-se uma solução de $\mathrm{H}_{2} \mathrm{SO}_{4}$ concentrado juntamente com fenol 5\%. A curva-padrão foi construída utilizando-se glicose e a leitura foi realizada em espectrofotômetro $(490 \mathrm{~nm})$ utilizando-se cubeta de vidro.

Figura 9 - Fluxograma da extração de açúcares residuais do bagaço de cana-de-açúcar

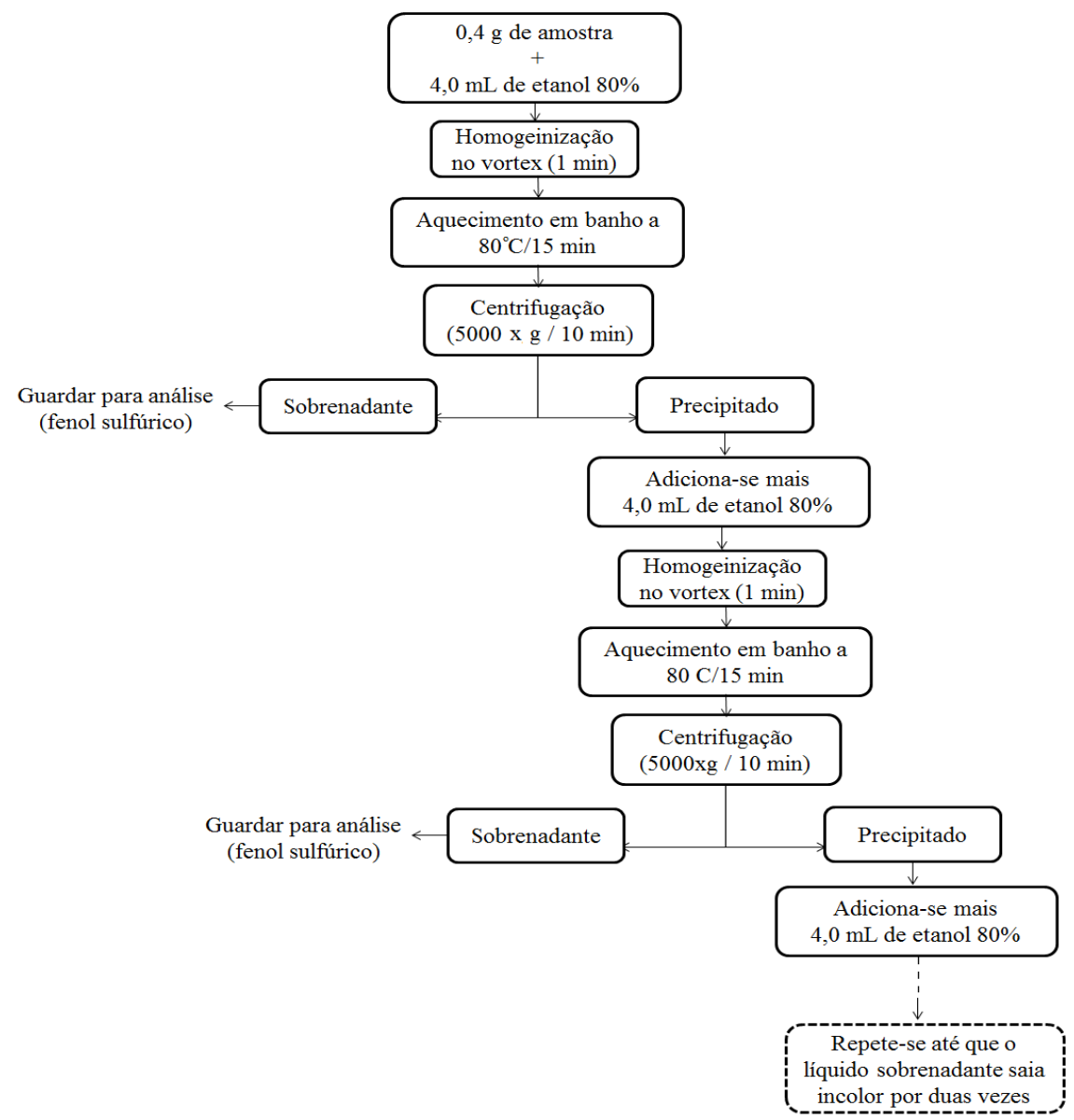

Fonte: Arquivo pessoal. 
4.12.9 Determinação da capacidade absortiva do bagaço de cana-de-açúcar

O bagaço de cana-de-açúcar foi umedecido com meio de cultivo, progressivamente, até que a máxima capacidade absortiva fosse atingida. A máxima capacidade absortiva foi determinada como o volume máximo de meio absorvido antes de haver água livre no sistema. As adições de meio ao substrato foram seguidas por etapa de homogeneização e repouso de 45 a 90 min em copo de Becker vedado com parafilme. Uma vez determinada a máxima capacidade absortiva, uma amostra do bagaço foi então umedecida na condição estabelecida como máxima e a umidade determinada utilizando-se balança de infravermelho (Termobalança Top-Ray, Tecnal). Porções de substrato sólido umedecido, de massa entre 1 a $3 \mathrm{~g}$, foram introduzidas no forno de infravermelho da balança e então submetidas a $100{ }^{\circ} \mathrm{C}$ até massa constante. A umidade do substrato foi então calculada como porcentagem em massa de meio contida no substrato.

4.12.10 Avaliação qualitativa da produção de celulases

A avaliação qualitativa da produção de celulases foi feita de acordo com a metodologia descrita por Nogueira e Cavalcanti (1996). Para tanto, a levedura foi cultivada em meio sintético contendo carboximetilcelulose (CMC) como única fonte de carbono. Meio mineral base foi composto por: $\mathrm{NaNO}_{3} 3,0 \mathrm{~g} / \mathrm{L}, \mathrm{K}_{2} \mathrm{HPO}_{4}$ 1,0 g/L, $\mathrm{MgSO}_{4}$ 0,5 g/L, KCl 0,5 g/L, FeSO $4.7 \mathrm{H}_{2} \mathrm{O}$, $0,01 \mathrm{~g} / \mathrm{L}$ e agar $20,0 \mathrm{~g} / \mathrm{L}$.

$\mathrm{O}$ teste foi realizado em duplicata e um controle negativo. As placas foram incubadas a $28{ }^{\circ} \mathrm{C}$ por $96 \mathrm{~h}$. Após o tempo de incubação foram adicionados na placa $10 \mathrm{~mL}$ da solução de vermelho do congo (2,5 g/L em tampão Tris $\mathrm{HCl}$ 0,1 M, pH 8,0). Após 30 min a solução foi descartada e as placas lavadas com $5 \mathrm{~mL}$ de solução de $\mathrm{NaCl}$ 0,5 M. A presença de halo mais claro foi considerado como resultado positivo.

4.12.11 Avaliação qualitativa da produção de xilanases

A avaliação qualitativa da produção de xilanases foi feita de acordo com a metodologia descrita por Whitaker (2002) adaptada. Para tanto, a levedura foi cultivada em meio sintético contendo xilana como única fonte de carbono. Foi utilizado o mesmo meio mineral base, tempo e condições de incubação descrita para o teste qualitativo de celulase (4.12.10). A presença de 
halo claro após a adição da solução de vermelho do congo (30 min) e lavagem com solução de $\mathrm{NaCl}$ (soluções descritas no ítem 4.12.10) foi considerado como resultado positivo.

\subsubsection{Avaliação qualitativa da produção de polifenol oxidases}

Para avaliação qualitativa da produção de ligninases foi utilizada a metodologia proposta por Pointing (1999). Este ensaio fornece uma indicação da atividade global de polifenóis oxidases e não é específica para algum dos tipos de ligninases (lacase, manganês peroxidase ou lignina peroxidase).

A levedura foi cultivada em meio sintético contendo ácido tânico como única fonte de carbono. Foi utilizado o mesmo meio mineral base, tempo e condições de incubação descrita para o teste qualitativo de celulase (4.12.10). A presença de halo róseo em torno da colônia após o tempo de incubação foi considerada como resultado positivo.

4.12.13 Avaliação da atividade de celulases totais (FPA) na fermentação em estado sólido

A atividade de celulases totais foi determinada adaptando o método descrito por Ghose (1987). Utilizou-se tubos de $30 \mathrm{~mL}$ para a condução da reação enzimática, contendo 1,0 mL de tampão acetato de sódio $50 \mathrm{mM}, \mathrm{pH} 4,8$, uma tira de papel de filtro $(1,0 \times 6,0 \mathrm{~cm}$, aproximadamente $50 \mathrm{mg}$ ) e $0,5 \mathrm{~mL}$ do extrato enzimático bruto (obtido pela extração da FES) nas diluições 1:1, 1:2, 1:4 e 1:6 (em triplicata). Os tubos de ensaio foram aquecidos a $50{ }^{\circ} \mathrm{C}$ por $60 \mathrm{~min}$. Após o tempo da reação foram adicionados 3,0 mL de ácido 3,5-dinitro salicílico (DNS) e a mistura foi fervida por $5 \mathrm{~min}$ (MILLER, 1959). Em seguida, foram adicionados $20 \mathrm{~mL}$ de água destilada em cada tubo de mistura, os quais foram agitados e deixados em repouso por 20 min. A leitura da absorbância foi feita a $540 \mathrm{~nm}$. Foram feitos controles para cada amostra, adicionando o DNS antes do extrato enzimático. O valor de absorbância do controle foi descontado da respectiva amostra. A conversão dos valores das absorbâncias em massa de glicose por meio da curva de calibração (utilizando soluções de glicose nas concentrações 1; $1,65 ; 2,5 ; 3,3 \mathrm{mg} / 0,5 \mathrm{~mL})$ e usados para a construção do gráfico relacionando o inverso das diluições da enzima (1/diluição) pela quantidade de glicose liberada. Para avaliação da atividade de celulases totais utilizou-se a equação de reta obtida para determinar o inverso da diluição da enzima (eixo y) que resulta na liberação de 2,0 mg de glicose (correspondente a 4\% 
de conversão de celulose). Para o cálculo da atividade em FPU/mL esse valor é dividido por 0,37 . O fator 0,37 corresponde à conversão de $2 \mathrm{mg}$ de glicose em $1 \mu \mathrm{mol}$ de glicose por minuto, levando em consideração o volume de amostra e o tempo de reação.

4.12.14 Avaliação da atividade de xilanases na fermentação em estado sólido

A atividade de xilanases foi determinada pela metodologia de Bailey, Biely e Poutanen (1992). Utilizou-se tubos de $10 \mathrm{~mL}$ para a condução da reação enzimática, contendo $0,9 \mathrm{~mL}$ de xilana $1 \%$ e $0,1 \mathrm{~mL}$ de extrato enzimático bruto (obtido pela extração da FES) nas diluições 1:1, 1:2, 1:4 e 1:5 (em triplicata). Os tubos de ensaio foram aquecidos a $50{ }^{\circ} \mathrm{C}$ por $5 \mathrm{~min}$. Após o tempo da reação foram adicionados $3,0 \mathrm{~mL}$ de DNS e a mistura foi fervida por 5 min (MILLER, 1959). Após o resfriamento a leitura da absorbância foi feita a $540 \mathrm{~nm}$. Foram feitos controles para cada amostra, adicionando o DNS antes do extrato enzimático. $\mathrm{O}$ valor de absorbância do controle foi descontado da respectiva amostra. A curva padrão foi construída com soluções de xilose 4, 6, 8, 10, 12, 14, 16, 18 e $20 \mu \mathrm{mol} / \mathrm{mL}$. Uma unidade de atividade enzimática corresponde à formação de $1 \mu \mathrm{mol}$ de xilose por minuto.

\subsubsection{Observações microscópicas}

A morfologia das células crescidas em cada um dos meios de cultivo (contendo glicose, sacarose, manose, xilose e arabinose) e antes e após a extração de biossurfactantes foi avaliada utilizando microscópio óptico Motic BA400, em aumento de 400 x, com relação ao número de células, presença de vacúolos, presença de artroconídeos negros.

\subsubsection{Determinação do $\mathrm{pH}$}

Os valores de $\mathrm{pH}$ dos meios de cultivo e de soluções que necessitavam de ajuste de $\mathrm{pH}$ foram medidos em potenciômetro Ms Tecnopon m PA-200, calibrado com soluções padrão de pH 7,0 e pH 4,0. 
4.12.17 Determinação das concentrações de glicose, arabinose, frutose e manose.

As amostras foram preparadas para análise em HPLC filtradas em sep-pack C18 (millipore). Utilizou-se coluna Aminex HPX-87P, Biorad (300 x 7,8 mm) a $65^{\circ} \mathrm{C}$, como eluente água deionizada em um fluxo de $0,4 \mathrm{~mL} / \mathrm{min}$ e detecção por índice de refração RID 6A. Foram utilizados os padrões de glicose, arabinose, frutose, sacarose e manose em diferentes concentrações.

A determinação das concentrações de sacarose, frutose e glicose dos experimentos do planejamento em biorreator (item 4.5.3) para avaliação do efeito das variáveis fonte de carbono e aeração para a produção de biossurfactantes (realizado no Leibniz Institute for Agricultural Engineering and Bioeconomy em Potsdam-Bornim, Alemanha) foi analisada em HPLC (DIONEX, EUA), de acordo com a metodologia empregada por Pleissner e colaboradores (2016). As amostras foram filtradas em filtros de $0,22 \mu \mathrm{m}$ e uma alíquota de $10 \mu \mathrm{L}$ da amostra foi adicionada à coluna Eurokat $\mathrm{H}(300 \mathrm{~mm} \times 8 \mathrm{~mm} \times 10 \mu \mathrm{m}$, Knauer, Alemanha) e eluído isocraticamente com $0,8 \mathrm{~mL} / \mathrm{min}$ de $\mathrm{H}_{2} \mathrm{SO}_{4} 5 \mathrm{mM}$. A detecção foi realizada utilizando detector de índice de refração (RI-71, SHODEX, Japan).

\subsubsection{Determinação da concentração do biossurfactante produzido}

Para determinação da concentração em peso seco do biossurfactante produzido, um volume de $5 \mathrm{~mL}$ da solução de biosurfactante extraído com o solvente (item 4.12.19 ou 4.12.20) foi adicionado a cadinhos previamente pesados e mantidos na capela de exaustão por $12 \mathrm{~h}$ para que o solvente fosse evaporado. Após esse tempo, os cadinhos foram levados à estufa de secagem a $60{ }^{\circ} \mathrm{C}$ por mais $24 \mathrm{~h}$ para eliminar qualquer resquício de solvente e umidade. Então foram novamente pesados e a massa de biossurfactante produzida foi calculada pela diferença entre a massa final e inicial dos cadinhos. O mesmo processo foi realizado com o controle, contendo apenas solvente da extração realizada em meio não inoculado. O cálculo da produção de biossurfactantes em $\mathrm{g} / \mathrm{L}$ foi feito considerando o volume de amostra utilizado para a análise de peso seco. 
4.12.19 Extração com solvente do biossurfactante na fermentação submersa

Após fermentação submersa, o meio foi utilizado para a extração do biossurfactante de acordo com a metodologia utilizada por Kurosawa e colaboradores (1994) modificada. Misturou-se numa proporção 1:1 o volume de meio fermentado com o solvente butanona (metil etil cetona) P.A. para a extração em um funil de separação por três vezes. Em seguida, o excesso de solvente foi evaporado e a concentração de biossurfactante determinada (item 4.10.18) ou o biossurfactante extraído foi utilizado em testes posteriores de hidrólise e caracterização.

4.12.20 Extração do biossurfactante produzido por fermentação em estado sólido

Para a extração do biossurfactante produzido na FES, os cultivos foram interrompidos e adicionou-se volume adequado (item 4.6) de água destilada estéril em cada frasco, os quais foram deixados sob agitação em agitador rotatório a $200 \mathrm{rpm}$ a $30{ }^{\circ} \mathrm{C}$ por 1 hora. Na sequiência, a mistura foi filtrada em gaze e prensada manualmente. Em seguida adicionou-se butanona ao extrato resultante da filtração com gaze (1:1), sendo o biossurfactante extraído para fase apolar.

Também foi testada para a FES a adição direta de butanona (no mesmo volume utilizado para água destilada) nos frascos de fermentação, os quais foram deixados sob agitação em agitador rotatório a $200 \mathrm{rpm}$ a $30{ }^{\circ} \mathrm{C}$ por 1 hora. Na seqüência, a mistura foi filtrada em gaze e prensada manualmente, seguindo a mesma sequencia da extração com água destilada.

Em seguida, o excesso de solvente foi evaporado e a concentração de biossurfactante determinada (item 4.10.18) ou o biossurfactante extraído foi utilizado em testes posteriores de hidrólise e caracterização.

\subsubsection{Hidrólise do biossurfactante}

Para a hidrólise do biossurfactante extraído, primeiramente evaporou-se o solvente, aquecendo uma alíquota de $2,0 \mathrm{~mL}$ em tubo de ensaio a $90{ }^{\circ} \mathrm{C}$ no banho-maria em capela de exaustão até completa evaporação do solvente. Em seguida, o biossurfactante foi ressuspenso no mesmo volume inicial $(2,0 \mathrm{~mL})$ de água destilada. Este procedimento foi realizado em duplicata.

A hidrólise foi realizada adicionando-se aos 2,0 mL da solução de biossurfactante já em meio aquoso, $200 \mu \mathrm{L}$ de $\mathrm{H}_{2} \mathrm{SO}_{4}$ a 10M. Essa solução foi aquecida por $2 \mathrm{~h}$ e, ao final, foram acrescentados $200 \mu \mathrm{L}$ de $\mathrm{NaOH}$ a $10 \mathrm{M}$. O biossurfactante hidrolisado foi utilizado para as 
análises bioquímicas descritas a seguir. Este procedimento foi adaptado da metodologia de Peixoto (2008).

\subsubsection{Análise de proteínas}

Para avaliar a presença de proteínas na molécula de biossurfactante hidrolisado, utilizou-se a metodologia descrita por Bradford (1976). A concentração de proteínas foi determinada a partir de uma curva padrão preparada com albumina sérica bovina (BSA). Alíquotas de $100 \mu \mathrm{L}$ das amostras foram misturadas com 2,5 mL do reagente de Bradford e, após dez minutos, a absorbância foi determinada em espectrofotômetro a $595 \mathrm{~nm}$. O branco do ensaio foi preparado misturando-se $100 \mu \mathrm{L}$ de água destilada mais $2,5 \mathrm{~mL}$ do reagente. Todas as amostras foram ensaiadas em triplicata.

\subsubsection{Análise de lipídeos}

Para avaliar a presença de lipídeos na molécula de biossurfactante hidrolisado, utilizouse a metodologia adaptada der Izard e Limberger (2003). A concentração de lipídeos foi determinada a partir de uma curva-padrão preparada com ácido linolênico em diferentes concentrações. Alíquotas de $100 \mu \mathrm{L}$ das amostras foram adicionadas a 2,0 mL de $\mathrm{H}_{2} \mathrm{SO}_{4} 18 \mathrm{M}$ e aquecidas a $100{ }^{\circ} \mathrm{C}$ por $10 \mathrm{~min}$. Após resfriamento, adicionou-se $5 \mathrm{~mL}$ do reagente de ácido fosfórico - vanilina e após 15 min a $37{ }^{\circ} \mathrm{C}$ foi feita a leitura em espectrofotômetro no comprimento de onda de $530 \mathrm{~nm}$. O branco do ensaio foi preparado utilizando $100 \mu \mathrm{L}$ de água destilada no lugar da amostra e procedendo as mesmas etapas feitas para a amostra. Todas as amostras foram ensaiadas em triplicata.

\subsubsection{Análise de açúcares redutores}

Para avaliar a presença de açúcares redutores na molécula de biossurfactante hidrolisado, utilizou-se a metodologia adaptada do ácido 3,5-dinitro salicílico (DNS) descrita por Miller (1959). A concentração de açúcares foi determinada a partir de uma curva padrão preparada com glicose em diferentes concentrações. Alíquotas de 1,0 mL das amostras foram misturadas com 1,0 $\mathrm{mL}$ do reagente DNS aquecidos por $5 \mathrm{~min}$ em água fervente e, após resfriamento em banho de gelo adicionou-se 5,0 mL de água destilada. A absorbância foi 
determinada em espectrofotômetro a $540 \mathrm{~nm}$. O branco do ensaio foi preparado misturando-se 1,0 mL de água destilada em substituição da amostra e 1,0 $\mathrm{mL}$ do reagente, aquecidos por 5 min em água fervente e após resfriamento adicionou-se mais 5,0 $\mathrm{mL}$ de água destilada. Todas as amostras foram ensaiadas em triplicata.

4.12.25 Análise de açúcares e polióis por cromatografia líquida de alta eficiência (HPLC)

Para avaliar a presença dos polióis glicerol, manitol, arabitol e outros açúcares, as amostras de biossurfactante hidrolisado foram preparadas para análise em HPLC filtradas em sep-pack C18 (millipore). Utilizou-se coluna Aminex HPX-87H, Biorad (300 x 7,8 mm) a 45 ${ }^{\circ} \mathrm{C}$, como eluente água solução de $\mathrm{H}_{2} \mathrm{SO}_{4}$ 0,001 $\mathrm{N}$ e um fluxo de $0,6 \mathrm{~mL} / \mathrm{min}$ e detecção por índice de refração RID 6A. Foram utilizados os padrões de glicerol, manitol, arabitol, xilitol, glicose, xilose, arabinose, e celobiose em diferentes concentrações.

\subsubsection{Determinação do $\mathrm{K}_{\mathrm{La}}$}

$\mathrm{O}$ coeficiente de transferência de oxigênio $\left(\mathrm{K}_{\mathrm{L}} \mathrm{a}\right)$ foi determinado pela metodologia do “gassing out", em biorreator BIOSTAT BPlus de 5 L (Sartorius AG, Alemanha) contendo 3 L de meio de cultivo sem células. O oxigênio do meio foi removido por purga com gás nitrogênio até que a concentração de oxigênio dissolvido chegasse a zero. A aeração do sistema então foi iniciada com uma agitação de 300 rpm e o aumento da concentração de oxigênio dissolvido foi monitorado em função do tempo usando eletrodo de oxigênio (Hamilton, OXYFERM FDA 325, Suíça). Por integração da equação de balanço de oxigênio no meio líquido (Equação 4), o valor de $\mathrm{K}_{\mathrm{L}}$ foi determinado.

Ao integrar a equação do equilíbrio de oxigênio no meio líquido, o valor de $\mathrm{K}_{\mathrm{L}} \mathrm{a}$ em cada condição foi determinado:

$$
\begin{aligned}
& \frac{d C}{d t}=K_{L} a\left(C^{*}-C\right) \\
& \ln \left(1-\frac{C}{C^{*}}\right)=-K_{L} a \times t
\end{aligned}
$$

Onde:

$\frac{C}{C^{*}}=$ corresponde à leitura do eletrodo (fração da concentração de $\mathrm{O}_{2}$ dissolvido em relação à concentração de saturação). 
Calculou-se o valor de $\mathrm{K}_{\mathrm{La}}\left(\mathrm{h}^{-1}\right)$ em função da linearização do gráfico do logaritmo de $\left(1-\frac{C}{C^{*}}\right)$ em função do tempo.

\subsubsection{Teste de biorremediação}

O teste foi realizado em frascos Erlenmeyer de $100 \mathrm{~mL}$ contendo $20 \mathrm{~g}$ de areia seca e previamente esterilizada contaminada artificialmente com $10 \%(\mathrm{~m} / \mathrm{m})$ de petróleo cru e agitados em shaker orbital a $200 \mathrm{rpm}, 30^{\circ} \mathrm{C}$ por $24 \mathrm{~h}$. Após este tempo, $40 \mathrm{~mL}$ de solução para recuperação do óleo foram adicionados. Para tanto testou-se a solução 0,01\% e 0,05\% (m/v) de biossurfactante, solução $0,01 \%$ e $0,05 \%(\mathrm{~m} / \mathrm{v})$ de dodecil sulfato sódico (SDS) e solução controle utilizando-se água desmineralizada (PEREIRA et al., 2013). Para cada solução foram feitos testes em triplicata. Os frascos contendo areia contaminada e solução para recuperação do petróleo foram incubados a $100 \mathrm{rpm}$ e $30^{\circ} \mathrm{C}$ durante $24 \mathrm{~h}$ e, posteriormente, centrifugadas a 1800 x g por 20 min. O sobrenadante foi descartado e o petróleo remanescente na areia após a ação da solução de recuperação foi determinado por análise gravimétrica.

Para a análise gravitométrica, o petróleo residual (que ficou retido na areia após ação da solução de recuperação) foi extraído utilizando-se diclorometano e adicionado em cadinhos previamente pesados. A extração foi repetida duas vezes para garantir que todo o petróleo havia sido extraído. Os cadinhos foram mantidos a $70^{\circ} \mathrm{C}$ por $24 \mathrm{~h}$ para total evaporação do diclorometano ( $2 \mathrm{~h}$ após a primeira pesagem foram pesados novamente para verificação de peso constante). A porcentagem de recuperação foi calculada pelo método descrito por Aparna e colaboradores (2011):

$$
\begin{aligned}
& P r=P c o-P c \\
& P r e c=P o-P r \\
& \% \text { rec }=(P r e c \div P o) \times 100
\end{aligned}
$$

Sendo:

$$
\begin{aligned}
& \operatorname{Pr}=\text { Peso do petróleo residual } \\
& P c o=\text { Peso do cadinho com o petróleo extraído } \\
& P c=\text { Peso do cadinho } \\
& P r e c=\text { Quantidade de petróleo recuperado } \\
& P o=\text { Peso do óleo adicionado ao meio } \\
& \% \text { rec = Porcentagem de recuperação }
\end{aligned}
$$




\section{RESULTADOS E DISCUSSÃO}

\subsection{Identificação das leveduras produtoras de biossurfactantes}

As 37 linhagens de leveduras, dos gêneros Candida, Trichosporon, Issatchenkia, Pichia, Spathaspora, Kluyveromyces, Saccharomyces e Aureobasidium, isoladas da biodiversidade brasileira foram testadas para identificação daquelas que são capazes de produzir biossurfactantes. Foram utilizadas metodologias baseadas na atividade tensoativa (testes de atividade hemolítica, escorrimento da gota, espalhamento da gota e colapso da gota) e na atividade emulsificante da molécula (testes de índice de emulsificação e avaliação da estabilidade e aspecto da emulsão formada). Os resultados foram apresentados separadamente, pois as atividades (tensoativa ou emulsificante) do biossurfactante dependem do tamanho e da estrutura da molécula produzida (SATPUTE et al., 2010; MONTEIRO et al., 2010; SMITH et al., 2010). Portanto, dependendo do tipo de biossurfactante produzido pela levedura, este apresentará maior atividade tensoativa ou emulsificante.

Os resultados dos testes utilizados para a identificação da produção de biossurfactantes com característica tensoativa estão apresentados na Tabela 10. Observou-se que as leveduras SSS03, SSS04, SSS11, SSS22, SSS31, SSS33, SSS34, SSS38 apresentaram resultados positivos para todos os testes, confirmando a produção de biossurfactantes com característica tensoativa por estas leveduras e, portanto, estas foram selecionadas para próxima etapa do trabalho (teste da produção em FES).

Dentre as 37 leveduras testadas, apenas a levedura SSS09, SSS10, SSS13, SSS14, e SSS30 não apresentaram resultado positivo para nenhum dos testes (Tabela 10), indicando que estas leveduras possivelmente não são produtoras de biossurfactantes.

As leveduras SSS01, SSS05, SSS06, SSS15, SSS17, SSS21, SSS25, SSS26, SSS27 e SSS28 apresentaram resultados positivos para o teste de atividade hemolítica, entretanto não apresentaram resultados positivos para nenhum dos demais testes apresentados na Tabela 10. Este resultado demonstra que o método de atividade hemolítica não é conclusivo para avaliar a produção de biossurfactantes e pode apresentar falsos positivos. Estas leveduras não foram consideradas produtoras de biossurfactante com atividade tensoativa. Os falsos positivos podem ser explicados devido ao fato de que outras moléculas que causam lise celular podem ser excretadas no meio pelo micro-organismo, sem necessariamente ser um composto com atividade surfactante (PLAZA et al., 2006). 
Tabela 10 - Resultado dos testes de identificação de leveduras produtoras de biossurfactantes baseados na sua atividade tensoativa. Teste realizado após 72 h de cultivo em meio Kitamoto.

\begin{tabular}{|c|c|c|c|c|}
\hline Levedura & $\begin{array}{l}\text { Atividade } \\
\text { hemolítica }\end{array}$ & $\begin{array}{c}\text { Escorrimento } \\
\text { da gota }\end{array}$ & $\begin{array}{c}\text { Espalhamento } \\
\text { da gota }\end{array}$ & $\begin{array}{c}\text { Colapso da } \\
\text { gota }\end{array}$ \\
\hline SSS01 & + & - & - & - \\
\hline SSS02 & + & - & + & + \\
\hline SSS03 & + & + & + & + \\
\hline SSS04 & + & + & + & + \\
\hline SSS05 & + & - & - & - \\
\hline SSS06 & + & - & - & - \\
\hline SSS07 & + & - & + & + \\
\hline SSS08 & + & - & + & - \\
\hline SSS09 & - & - & - & - \\
\hline SSS10 & - & - & - & - \\
\hline SSS11 & + & + & + & + \\
\hline SSS12 & + & + & + & - \\
\hline SSS13 & - & - & - & - \\
\hline SSS14 & - & - & - & - \\
\hline SSS15 & + & - & - & - \\
\hline SSS16 & + & + & + & - \\
\hline SSS17 & + & - & - & - \\
\hline SSS18 & + & - & + & + \\
\hline SSS19 & + & + & + & - \\
\hline SSS20 & + & + & + & - \\
\hline SSS21 & + & - & - & - \\
\hline $\mathrm{SSS} 22$ & + & + & + & + \\
\hline $\mathrm{SSS} 23$ & + & + & + & - \\
\hline SSS24 & + & + & + & - \\
\hline SSS25 & + & - & - & - \\
\hline SSS26 & + & - & - & - \\
\hline SSS27 & + & - & - & - \\
\hline SSS28 & + & - & - & - \\
\hline
\end{tabular}

Continua 
Conclusão

\begin{tabular}{ccccc}
\hline Levedura & $\begin{array}{c}\text { Atividade } \\
\text { hemolítica }\end{array}$ & $\begin{array}{c}\text { Escorrimento } \\
\text { da gota }\end{array}$ & $\begin{array}{c}\text { Espalhamento } \\
\text { da gota }\end{array}$ & $\begin{array}{c}\text { Colapso da } \\
\text { gota }\end{array}$ \\
\hline SSS29 & + & - & + & + \\
SSS30 & - & - & - & - \\
SSS31 & + & + & + & + \\
SSS32 & + & + & + & + \\
SSS33 & + & + & + & + \\
SSS34 & + & + & + & - \\
SSS37 & + & + & + & + \\
SSS38 & + & + & + & - \\
SSS39 & + & & & + \\
\hline
\end{tabular}

Fonte: Arquivo pessoal.

A atividade hemolítica é caracterizada pela formação de um halo de hemólise ao redor da colônia do micro-organismo crescido em ágar sangue, como demonstrado na Figura 10.

Figura 10 - Formação de halo devido à atividade hemolítica do micro-organismo em ágar sangue. Teste das leveduras SSS05, SSS06, SSS07 e SSS08 em duplicata.

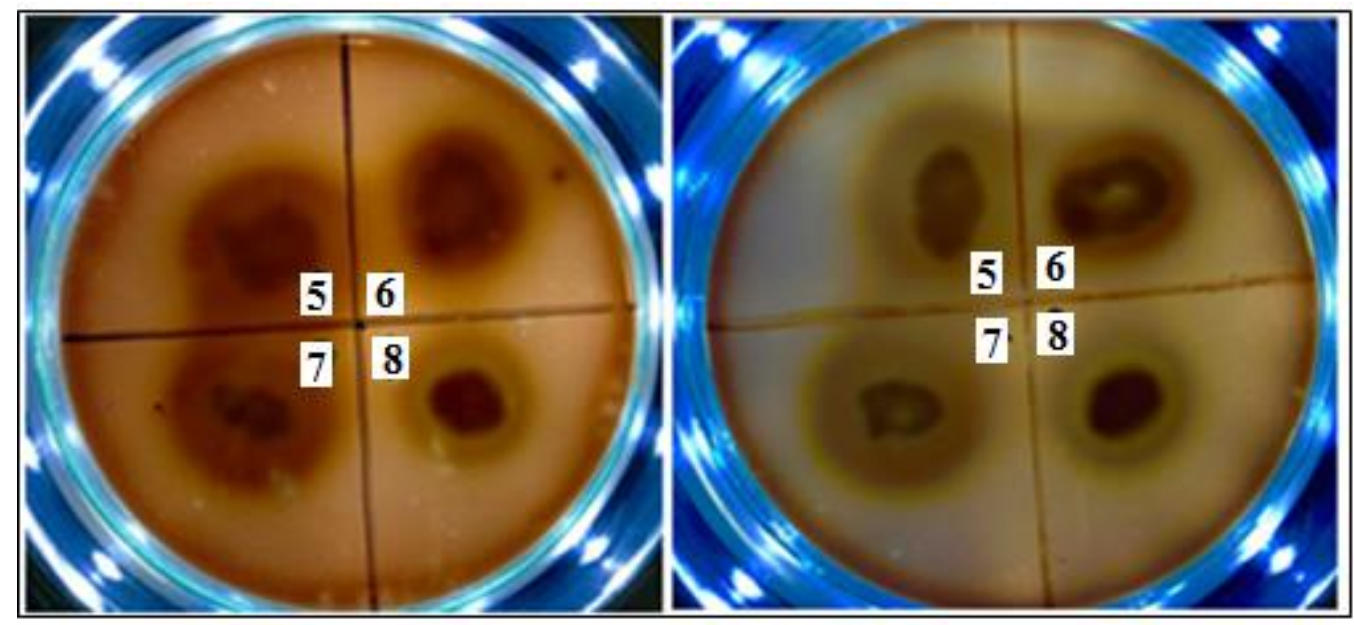

Fonte: Arquivo pessoal

Youssef e colaboradores (2004) relataram em seu trabalho a presença de falsos positivos e falsos negativos ao utilizar a metodologia de atividade hemolítica para seleção de microorganismos produtores de biossurfactantes. Porém, no presente trabalho foi observado que as 
leveduras que apresentaram resultados negativos no teste de atividade hemolítica também não apresentaram resultados positivos nos demais testes, o que indica que não houve resultados falsos negativos neste teste.

Ainda de acordo com a Tabela 10, as leveduras SSS02, SSS07, SSS12, SSS16, SSS18, SSS19, SSS20, SSS23, SSS24, SSS29, SSS32, SSS37 e SSS39 apresentaram resultados negativos a somente em um dos testes: escorrimento da gota ou colapso da gota, e a levedura SSS08 apresentou resultado negativo para os testes de escorrimento da gota e colapso da gota. Uma explicação para essa variação de resultados entre os testes é o fato de estes métodos apresentarem menor sensibilidade. Outros trabalhos que compararam métodos de seleção de micro-organismo produtores de biossurfactantes relataram a possibilidade de falso negativo nestes testes quando a concentração de biossurfactante presente na amostra analisada for muito baixa ou este apresentar maior atividade emulsificante que tensoativa (SATPUTE et al, 2008; SATPUTE et al, 2010). Este resultado demonstrou que as leveduras SSS02, SSS07, SSS12, SSS16, SSS18, SSS19, SSS20, SSS23, SSS24, SSS29, SSS32, SSS37 e SSS39 podem ter produzido biossurfactantes, porém em menor concentração e/ou com características estruturais diferentes quando comparadas àquelas que apresentaram resultados positivo para todos os testes baseados na tensoatividade.

Devido à necessidade de confirmação de resultados duvidosos e avaliação de possíveis falsos positivos e falsos negativos, muitos autores sugerem que mais de um teste deve ser utilizado para se chegar a resultados conclusivos (SATPUTE et al., 2008; SATPUTE et al., 2010; MULLIGAN et al., 1984; MAKKAR; CAMEOTRA, 2002). Além disso, é uma forma de avaliar o tipo de atividade do biossurfactante produzido pelo micro-organismo testado.

Para confirmação da produção ou não de biossurfactantes com características emulsionantes pelas leveduras que apresentaram resultados negativos em alguns dos testes e identificação da produção de biossurfactantes com características tensoativas, foram analisados os resultados dos testes de índice de emulsificação, estabilidade e aspecto da emulsão (Tabela $11)$. 
Tabela 11 - Resultado dos testes de identificação de leveduras produtoras de biossurfactantes baseados na sua atividade emulsificante. Testes realizados após 72 h de cultivo em meio Kitamoto.

\begin{tabular}{|c|c|c|c|c|c|}
\hline Leveduras & $\mathrm{IE}^{*}(1 \mathrm{~h})$ & IE* (24 h) & $\mathrm{IE}^{*}(168 \mathrm{~h})$ & $\operatorname{Aspecto*}^{*}(24 h)$ & $\mathbf{E E}^{* * * *(\%)}$ \\
\hline SSS01 & $0,0 \pm 0,0$ & $0,0 \pm 0,0$ & $0,0 \pm 0,0$ & - & - \\
\hline SSS02 & $44,1 \pm 1,7$ & $44,1 \pm 0,1$ & $41,1 \pm 0,1$ & Emulsão consistente & 93,2 \\
\hline SSS03 & $44,1 \pm 4,5$ & $44,1 \pm 3,4$ & $38,2 \pm 3,4$ & Emulsão consistente & 86,6 \\
\hline SSS04 & $47,1 \pm 3,4$ & $47,1 \pm 4,5$ & $47,1 \pm 6,8$ & Emulsão consistente & 100 \\
\hline SSS05 & $52,9 \pm 3,4$ & $50,0 \pm 1,7$ & $42,9 \pm 6,8$ & Emulsão consistente & 85,8 \\
\hline SSS06 & $44,1 \pm 1,7$ & $44,1 \pm 2,9$ & $38,2 \pm 0,3$ & Emulsão consistente & 86,6 \\
\hline SSS07 & $47,1 \pm 14,8$ & $47,1 \pm 18,9$ & $29,4 \pm 8,9$ & Coalescência & 62,9 \\
\hline SSS08 & $47,1 \pm 2,9$ & $47,1 \pm 6,1$ & $52,9 \pm 23,7$ & Coalescência & 87,6 \\
\hline SSS09 & $47,1 \pm 3,4$ & $44,1 \pm 31,4$ & $0,4 \pm 20,4$ & Coalescência & 0,1 \\
\hline SSS10 & $38,2 \pm 7,4$ & $38,2 \pm 5,1$ & $23,5 \pm 3,4$ & Coalescência & 61,5 \\
\hline SSS11 & $32,3 \pm 20,6$ & $32,3 \pm 21,3$ & $29,4 \pm 18,9$ & Coalescência & 91,0 \\
\hline SSS12 & $67,6 \pm 1,7$ & $64,7 \pm 1,7$ & $17,6 \pm 15,6$ & Coalescência & 27,2 \\
\hline SSS13 & $35,3 \pm 22,3$ & $35,3 \pm 22,7$ & $17,6 \pm 17,6$ & Coalescência & 49,8 \\
\hline SSS14 & $32,3 \pm 5,1$ & $32,2 \pm 20,4$ & $29,4 \pm 18,9$ & Coalescência & 91,3 \\
\hline SSS15 & $35,3 \pm 11,9$ & $35,2 \pm 23,3$ & $29,4 \pm 18,9$ & Coalescência & 83,5 \\
\hline SSS16 & $52,9 \pm 3,4$ & $52,9 \pm 5,1$ & $47,1 \pm 0,1$ & Emulsão consistente & 89,0 \\
\hline SSS17 & $44,1 \pm 1,7$ & $44,1 \pm 1,7$ & $41,1 \pm 5,9$ & Emulsão consistente & 100 \\
\hline SSS18 & $32,3 \pm 1,7$ & $32,3 \pm 1,7$ & $29,4 \pm 3,4$ & Coalescência & 91,0 \\
\hline SSS19 & $32,3 \pm 1,7$ & $32,3 \pm 1,7$ & $23,6 \pm 3,4$ & Coalescência & 73,0 \\
\hline SSS20 & $58,8 \pm 3,4$ & $58,8 \pm 3,4$ & $23,6 \pm 3,4$ & Emulsão consistente & 39,9 \\
\hline SSS21 & $47,1 \pm 3,4$ & $47,1 \pm 3,4$ & $44,1 \pm 3,4$ & Emulsão consistente & 93,6 \\
\hline SSS22 & $38,2 \pm 25,0$ & $38,2 \pm 25,0$ & $41,1 \pm 14,5$ & Coalescência & 92,4 \\
\hline SSS23 & $38,2 \pm 4,9$ & $38,2 \pm 4,5$ & $0,0 \pm 0,0$ & Coalescência & 0 \\
\hline SSS24 & $0,0 \pm 0,0$ & $0,0 \pm 0,0$ & $0,0 \pm 0,0$ & - & - \\
\hline SSS25 & $38,2 \pm 20,0$ & $38,2 \pm 20,0$ & $35,2 \pm 12,3$ & Emulsão consistente & 92,4 \\
\hline SSS26 & $32,3 \pm 3,4$ & $32,3 \pm 3,4$ & $17,6 \pm 17,6$ & Coalescência & 54,48 \\
\hline SSS27 & $23,5 \pm 19,9$ & $23,5 \pm 19,9$ & $32,3 \pm 9,0$ & Coalescência & 62,5 \\
\hline SSS28 & $38,2 \pm 2,9$ & $38,2 \pm 2,5$ & $29,4 \pm 6,8$ & Coalescência & 76,9 \\
\hline SSS29 & $47,1 \pm 8,9$ & $47,1 \pm 9,0$ & $17,6 \pm 12,3$ & Coalescência & 37,36 \\
\hline
\end{tabular}

Continua 
Conclusão

\begin{tabular}{cccccc}
\hline Leveduras & IE* $\mathbf{1} \mathbf{h}$ & $\mathbf{I E} * \mathbf{2 4} \mathbf{h}$ & $\mathbf{I E} * \mathbf{1 6 8} \mathbf{h}$ & Aspecto**(24h) $^{*}$ & $\mathbf{E E} * *(\mathbf{\%})$ \\
\hline SSS30 & $29,4 \pm 13,5$ & $29,4 \pm 13,6$ & $17,6 \pm 3,4$ & Coalescência & 59,9 \\
SSS31 & $50,0 \pm 4,4$ & $50,0 \pm 4,5$ & $11,8 \pm 14,8$ & Emulsão & 23,6 \\
& & & & consistente & \\
SSS32 & $44,1 \pm 5,9$ & $44,1 \pm 5,9$ & $11,8 \pm 14,8$ & Coalescência & 26,7 \\
SSS33 & $52,9 \pm 5,1$ & $52,9 \pm 5,1$ & $0,0 \pm 0,0$ & Coalescência & 0 \\
SSS34 & $41,2 \pm 2,9$ & $41,2 \pm 2,9$ & $35,3 \pm 3,4$ & Coalescência & 85,6 \\
SSS37 & $52,9 \pm 2,9$ & $52,9 \pm 2,9$ & $47,1 \pm 3,4$ & Emulsão & 89,0 \\
& & & & consistente & \\
SSS38 & $64,7 \pm 8,5$ & $64,7 \pm 8,5$ & $58,8 \pm 3,4$ & Emulsão & 90,9 \\
& & & & consistente & \\
SSS39 & $61,8 \pm 10,6$ & $61,8 \pm 10,6$ & $61,8 \pm 3,4$ & Emulsão & 100 \\
& & & & consistente &
\end{tabular}

*IE: Índice de emulsificação (\%); **Aspecto da emulsão no tempo de 24 h; ***Estabilidade da emulsão. Fonte: Arquivo pessoal.

De acordo com os resultados mostrados na Tabela 11, as leveduras que apresentaram emulsão consistente após 24 h foram SSS02, SSS03, SSS04, SSS05, SSS06, SSS16, SSS17, SSS20, SSS21, SSS25, SSS31, SSS37, SSS38, SSS39. Foi utilizado como critério de escolha das leveduras com melhores resultados nos testes onde se avaliou a atividade emulsificante (Tabela 11), aquelas que além de formarem emulsão consistente após $24 \mathrm{~h}$, também apresentaram estabilidade da emulsão maior que $80 \%$ num período de $168 \mathrm{~h}$. Desta forma, as leveduras que apresentaram resultados positivos foram SSS02, SSS03, SSS04, SSS05, SSS06, SSS16, SSS17, SSS21, SSS25, SSS37, SSS38 e SSS39 (Tabela 11). Pode-se observar que dentre aquelas que tinham apresentado resultados duvidosos nos testes que avaliaram a característica tensoativa do biossurfactante, apenas as leveduras SSS02, SSS16, SSS37 e SSS39 apresentaram resultados favoráveis (Tabela 11), indicando que houve produção de biossurfactantes por estas leveduras com característica emulsionante, por isso os testes que avaliam a atividade tensoativa não apresentaram resultados conclusivos.

O aspecto da emulsão formada é de grande importância, pois está relacionado com a sua estabilidade e aplicação. Emulsões mais consistentes são formadas por micelas menores e mais estáveis. A coalescência ocorre quando as micelas são instáveis e, devido à instabilidade, pode 
ocorrer junção das gotículas, levando à formação de glóbulos maiores que podem levar à separação das fases (RINALDI et al., 2007). Por essa razão, somente as leveduras que apresentaram emulsões consistentes neste teste foram consideradas para as próximas etapas do trabalho. A estabilidade da emulsão é outro critério importante, pois para aplicações industriais o biossurfactante deve formar emulsões estáveis.

Devido à coalescência, pode ocorrer aumento do índice de emulsificação com o passar do tempo, como ocorreu no teste das leveduras SSS08, SSS22 e SSS27 (Tabela 11). Este fato pode ser explicado, uma vez que a junção das micelas instáveis leva ao aumento do seu tamanho. Fenômeno semelhante foi observado por Bueno (2008) que encontrou alguns resultados o índice de emulsificação após $48 \mathrm{~h}$ maiores que o calculado para $24 \mathrm{~h}$.

A Figura 11 apresenta exemplos de resultado negativo (controle), presença de biossurfactante com atividade emulsionante (emulsão consistente,) e ausência de biossurfactante com atividade emulsionante (coalescência) no teste de emulsificação.

Figura 11 - Aspecto da emulsão formada no teste de emulsificação para avaliação da produção de biossurfactante

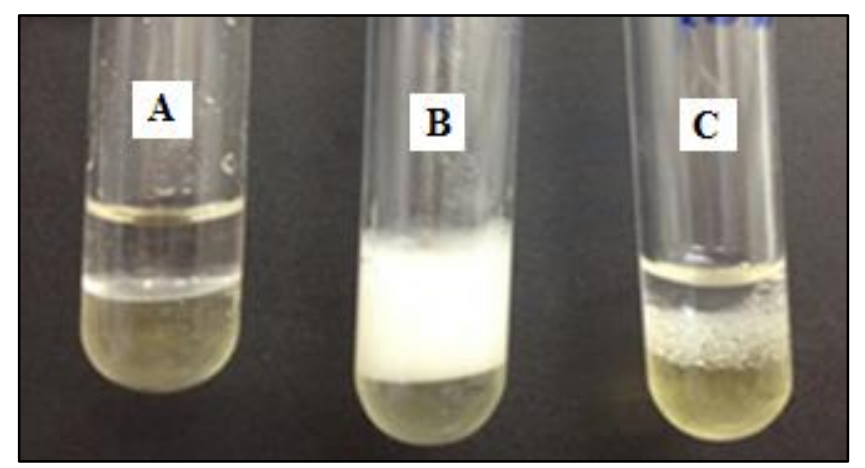

A: Tubo controle, ausência de emulsão; B: Presença de biossurfactante, emulsão consistente; C: Ausência de biossurfactante com atividade emulsionante, coalescência. Fonte: Arquivo pessoal.

Diversos trabalhos utilizam os testes de índice de emulsificação e estabilidade da emulsão tanto para avaliar a produção de biossurfactantes como para avaliar a sua atividade emulsionante (TECHAOEI et al., 2007; MONTEIRO et al., 2010; SATPUTE et al., 2008; CHANDER et al., 2012). De acordo com a Tabela 11, os índices de emulsificação encontrados no presente trabalho chegaram a valores superiores a 60\% (SSS38 e SSS39), o que representa um valor maior ou muito próximo de resultados relatados em trabalhos da literatura utilizando bactérias já conhecidas como boas produtoras de biossurfactante como Bacillus subtilis e Pseudomonas (ABDEL-MAWGOUD et al., 2008; BENTO et al., 2005; PRIETO et al., 2008; TECHAOEI et al., 2007; SATPUTE et al., 2008). Entretanto é importante salientar que em 
alguns testes a substância hidrofóbica utilizada no teste é diferente do querosene, utilizado neste trabalho. Este resultado é ainda mais expressivo considerando que as condições de produção de biossurfactantes neste trabalho ainda não foram otimizadas.

Diante dos resultados apresentados, os melhores resultados com relação à produção de biossurfactantes com atividade tensoativa (Tabela 10) e atividade emulsificante (Tabela 11), foram as leveduras SSS02, SSS03, SSS04, SSS05, SSS06, SSS11, SSS16, SSS17, SSS21, SSS22, SSS25, SSS31, SSS33, SSS34, SSS37, SSS38 e SSS39 as quais foram utilizadas para os testes de produção de biossurfactante por fermentação em estado sólido (FES).

\subsection{Seleção da levedura com maior potencial para a produção de biossurfactante} na FES

As 17 leveduras identificadas como produtoras de biossurfactantes foram cultivadas em FES utilizando bagaço de cana-de-açúcar como substrato umedecido com meio Kitamoto. Para avaliar a produção do biossurfactante por este processo, após o tempo de cultivo e extração, realizaram-se apenas os testes de espalhamento da gota e índice de emulsificação e estabilidade da emulsão (que avaliam a atividade emulsionante do biossurfactante).

O teste de espalhamento da gota foi escolhido como teste para avaliar a atividade tensoativa por apresentar menores resultados de falso positivo e falso negativo em resposta qualitativa e, de acordo com Youssef e colaboradores (2004) e Walter e colaboradores (2013), o diâmetro da abertura do halo na superfície do óleo neste teste está correlacionada com a atividade surfactante. De acordo com estes autores, para o biossurfactante puro existe uma correlação linear entre a concentração do biossurfactante e o diâmentro do halo obtido no teste.

Os testes foram conduzidos utilizando o sobrenadante obtido a partir da extração, conforme o ítem 4.3.3. Os resultados obtidos estão apresentados na Tabela 12.

Observa-se que quando cultivadas por FES, apenas as leveduras SSS03, SSS04, SSS33, SSS34 e SSS39 apresentaram resultados positivos para o teste de espalhamento da gota (Tabela 12). Entretanto, a levedura SSS33 deve ser destacada, pois o halo que se formou durante o teste devido à presença de biossurfactante sobressaiu-se dentre os resultados produzidos pelas outras leveduras que apresentaram resultados positivos. Essa é uma observação importante, uma vez que existe uma correlação entre a abertura do halo e a concentração do biossurfactante (YOUSSEF et al., 2004). Portanto, a levedura SSS33 apresentou uma maior produção de biossurfactante em FES quando comparada às demais leveduras testadas. Esta diferença entre as leveduras quando testadas em fermentação submersa não foi observada. 
Com relação ao índice de emulsificação, aspecto e estabilidade da emulsão as leveduras SSS02, SSS03, SSS33 e SSS34 foram aquelas que apresentaram formação de emulsão estável (Tabela 12). Estas leveduras apresentaram altos índices de emulsificação e estabilidade. A levedura que apresentou maior índice de emulsificação foi a SSS03 e aquela que apresentou a maior estabilidade foi a SSS33.

Tabela 12 - Resultados dos testes de espalhamento da gota e índice de emulsificação para avaliação de produção de biossurfactante por fermentação em estado sólido. Testes realizados após 72 h de cultivo utilizando meio Kitamoto como solução umedecedora

\begin{tabular}{cccccc}
\hline Leveduras & EG* & IE* $\mathbf{2 4} \mathbf{h}$ & IE* $^{*} \mathbf{6 8} \mathbf{h}$ & Aspecto**(24h) & EE***(\%) \\
\hline SSS02 & - & $57,0 \pm 5,7$ & $49,2 \pm 5,7$ & Emulsão consistente & 86,3 \\
SSS03 & + & $58,0 \pm 0,8$ & $52,5 \pm 1,9$ & Emulsão consistente & 90,6 \\
SSS04 & + & $51,0 \pm 2,2$ & $43,9 \pm 1,1$ & Coalescência & 86,2 \\
SSS05 & - & $22,8 \pm 0,0$ & $22,8 \pm 0,0$ & Coalescência & 100 \\
SSS06 & - & $13,6 \pm 7,8$ & $13,6 \pm 7,8$ & Coalescência & 100 \\
SSS11 & - & $50,5 \pm 3,1$ & $41,9 \pm 4,18$ & Coalescência & 82,9 \\
SSS16 & - & $22,3 \pm 2,3$ & $22,8 \pm 2,31$ & Coalescência & 100 \\
SSS17 & - & $50,7 \pm 3,4$ & $41,3 \pm 3,4$ & Coalescência & 81,5 \\
SSS21 & - & $25,6 \pm 14,2$ & $17,0 \pm 24,1$ & Coalescência & 66,5 \\
SSS22 & - & $10,3 \pm 0,8$ & $10,3 \pm 0,8$ & Coalescência & 100 \\
SSS25 & - & $0,0 \pm 0,0$ & $0,0 \pm 0,0$ & Coalescência & - \\
SSS31 & - & $37,6 \pm 1,5$ & $32,8 \pm 1,5$ & Coalescência & 87,5 \\
SSS33 & + & $53,5 \pm 0,8$ & $51,2 \pm 1,9$ & Emulsão consistente & 95,6 \\
SSS34 & + & $48,2 \pm 0,8$ & $37,3 \pm 11,8$ & Emulsão consistente & 77,3 \\
SSS37 & - & $39,7 \pm 1,5$ & $32,7 \pm 7,1$ & Coalescência & 82,3 \\
SSS38 & - & $45,3 \pm 1,1$ & $40,7 \pm 1,1$ & Coalescência & 89,7 \\
SSS39 & + & $44,6 \pm 4,4$ & $42,2 \pm 1,1$ & Coalescência & 94,7 \\
\hline EG Teste & + & & & \\
\hline
\end{tabular}

EG*: Teste do espalhamento da gota; *IE: Índice de emulsificação (\%); **Aspecto da emulsão no tempo de $24 \mathrm{~h}$; ***Estabilidade da emulsão. Fonte: Arquivo pessoal.

Em função dos resultados apresentados e em concordância com o objetivo do presente trabalho que foi selecionar uma levedura que apresentasse melhores desempenhos na fermentação em estado sólido, baseado nas características de atividade tensoativa e emulsificante demonstradas pelos testes realizados, selecionou-se a levedura SSS33 para as 
próximas etapas do trabalho, que buscaram determinar condições específicas e adequadas para a produção do biossurfactante por FES, visando aumentar o rendimento do processo.

É importante notar ainda que o índice de emulsificação apresentado pela levedura SSS33 na fermentação em estado sólido foi maior e a emulsão mais consistente quando comparado com aquele apresentado na fermentação submersa (Tabela 12). Isso pode indicar uma melhor adaptação ao meio sólido, uma vez que este se aproxima mais do habitat natural da levedura. Devido a este fato, a produção do biossurfactante pode ter sido maior na fermentação em estado sólido em relação à fermentação submersa.

\subsection{Características da levedura e do bagaço de cana-de-açúcar utilizados para a fermentação em estado sólido (FES)}

\subsubsection{Características da levedura selecionada}

De acordo com os resultados obtidos, a levedura selecionada como aquela que apresentou maior potencial para a produção de biossurfactantes por FES (SSS33) é o fungo leveduriforme Aureobasidium pullulans, que pertence ao filo Ascomycota, classe Dothideamiceto, subclasse Dothideomicetidae, segundo Hibbett et al. (2007). É um fungo ubíquo e saprofita muito comum em plantas cultivadas e frutos tropicais. Devido à produção de melanina, é conhecido também por "black yeast" (DESHPAND et al., 1992).

A levedura utilizada neste trabalho foi isolada de formiga bitu (Atta sexdens rubropilosa) coletada no Estado de São Paulo - Brasil em 2010 por Arcuri e colaboradores (2014). A identificação da levedura também foi realizada por esses autores pelo sequenciamento da região D1/D2 e da região ITS do DNA ribossômico. Esta levedura teve sua sequencia da região D1/D2 (571 pares de base) depositada do GenBank (99\% de similaridade, número de acesso FJ150916) e CBS (99,2\% de similaridade, número de acesso CBS 146.30) e a sequência gênica da região ITS (524 pares de base) também depositada no GenBank (99\% de similaridade, número de acesso FJ744598) e CBS (99,6\% de similaridade, número de acesso CBS 249.65). Para confirmação da linhagem como Aureobasidium pullulans, foi inferida uma árvore filogenética baseada no sequenciamento da região ITS com base nos dados publicados por Zalar e colaboradores (2008). A estirpe foi identificada pelos autores que a isolaram como Aureobasidium pullulans LB 83 (ARCURI et al., 2014). 
O fungo leveduriforme Aureobasidium pullulans é muito conhecido pela produção do exopolissacarídeo pululana (DESHPAND et al., 1992; SUGUMARAN et al., 2014). Foi descrito como produtor de uma substância extracelular chamada inicialmente de "heavy oil" pela primeira vez num estudo feito por Nagata et al. (1993). Mais tarde, o estudo da estrutura desta substância e sua classificação como um poliol lipídeo foi feito por Kurosawa et al. (1994) e a sugestão desta molécula como um tipo de biossurfactante foi feita por Manitchotpisit et al. (2011). Há relatos de outras aplicações dessa molécula, como agente antimicrobiano e atividade anticâncer (MANITCHOTPISIT et al., 2014). A concentração micelar crítica (CMC*) do biossurfactante produzido por A. pullulans é cerca de $10 \mu \mathrm{g} / \mathrm{mL}$ (ISODA; NAKAHARA, 1997).

Existem relatos na literatura da utilização de Aureobasidium pullulans em cultivo em estado sólido, entretanto os estudos se referem à produção de pululana e o substrato utilizado é bagaço de mandioca (SUGUMARAN et al., 2014; RAY; MOORTHY, 2007). Estes estudos já apontam o potencial deste micro-organismo para cultivo em FES.

\subsubsection{Caracterização do bagaço de cana-de-açúcar}

A metodologia utilizada para a determinação da composição química do material é de extrema importância em estudos de valorização de materiais lignocelulósicos (MOUBARIKA, et. al., 2013). Desta forma, o bagaço utilizado para a FES foi caracterizado com relação ao seu teor de celulose, hemicelulose, lignina, cinzas e extrativos (item 4.12.7). Para a metodologia de caracterização empregada, foram obtidos os seguintes resultados para as amostras em triplicata listados na Tabela 13.

Tabela 13 - Resultados da caracterização do bagaço de cana-de-açúcar

\begin{tabular}{cccccc}
\hline Composição (\%) & Amostra 1 & Amostra 2 & Amostra 3 & Média & Desvio Padrão \\
\hline Celulose & 34,16 & 33,90 & 34,82 & 34,29 & $\pm 0,39$ \\
Hemicelulose & 22,71 & 23,03 & 23,57 & 23,10 & $\pm 0,35$ \\
Lignina total & 28,99 & 27,79 & 28,64 & 28,47 & $\pm 0,50$ \\
Cinzas & 6,72 & 6,03 & 7,16 & 6,64 & $\pm 0,47$ \\
Extrativos & 5,32 & 5,00 & 5,83 & 5,38 & $\pm 0,34$ \\
TOTAL & 97,90 & 95,75 & 100,02 & 97,89 & $\pm 1,74$ \\
\hline
\end{tabular}

Fonte: Arquivo pessoal. 
Conforme a Tabela 13, os resultados encontrados na caracterização química do bagaço para celulose, hemicelulose e lignina foram em média de 34,29\%, 23,10\%; 28,47\%, respectivamente. Comparando esses valores com outros relatados na literatura, observamos que Moutta e colaboradores (2014), que utilizou a mesma metodologia para a caracterização de bagaço de cana-de-açúcar utilizada no presente trabalho, encontram os valores de 36,58\% para a celulose, $22,96 \%$ para hemicelulose e $27,34 \%$ para a lignina. No trabalho de Rezende e colaboradores (2011), que emprega a metodologia de caracterização validada por Gouveia et al. (2009), os resultados encontrados foram: $35,2 \%$ para a celulose, $24,5 \%$ para a hemicelulose e 22,2\% para a lignina. Da mesma forma, no trabalho reportado por Rocha et al. (2010), que também utiliza a mesma metodologia descrita por Gouveia et al. (2009), os valores encontrados na caracterização para celulose, hemicelulose e lignina foram de 45,5\%; 27,0\% e 21,1\%, respectivamente. Pode-se observar, portanto, que os valores encontrados no presente trabalho se aproximam do que é relatado na literatura. Mesmo levando em consideração as diferentes metodologias empregadas para a caracterização, os resultados se mantiveram relativamente próximos. Pequenas variações na composição do bagaço de cana-de-açúcar podem ocorrer de acordo com o tipo de cana e a região, solo e o clima que a cana-de-açúcar foi cultivada.

A concentração de açúcar residual foi outro fator avaliado no bagaço de cana-de-açúcar. Este açúcar pode ser proveniente do vestígio do caldo da cana após a moagem na usina. A determinação deste se faz necessária, uma vez que, mesmo submetido a sucessivos processos de lavagem, o bagaço ainda pode apresentar resíduos de açúcar os quais podem ser utilizados como fonte de carbono pelos micro-organismos na fermentação em estado sólido.

Encontrou-se a concentração de 1,05 mg de açúcares totais por grama de bagaço. Esse resultado mostra que além da suplementação proveniente do meio de cultivo utilizado como fonte umedecedora, o próprio bagaço possui nutrientes que podem ser assimilados pelos microorganismos. Nitschke e Pastore (2006) destacaram o potencial da utilização de resíduos agroindustriais para produção de biossurfactantes principalmente pelo seu baixo custo e por estes resíduos possuírem macro e micronutrientes que podem ser utilizados pelos microorganismos.

De acordo com o teste da capacidade absortiva do bagaço de cana-de-açúcar observouse que o volume máximo de solução umedecedora (meio de cultivo) adicionada ao bagaço até a sua saturação sem que líquido residual fosse observado foi de $5 \mathrm{~mL} / \mathrm{g}$ de bagaço de cana, o que correspondeu a uma umidade de $85 \%(\mathrm{~m} / \mathrm{m})$. A mesma capacidade absortiva foi observada por Camilios Neto (2010) para o bagaço de cana-de-açúcar. 


\subsection{Estudo exploratório da FES utilizando Aureobasidium pullulans LB 83}

Baseado na escolha da levedura realizou-se uma busca na literatura de um meio de cultivo adequado para a produção de biossurfactantes por Aureobasidium pullulans. Optou-se pelo meio de cultivo utilizado por Manitchotpisit (2011) para a produção de biossurfactante por Aureobasidium pullulans em fermentação submersa. Este meio de cultivo foi escolhido por já ser adequado à levedura selecionada e que apresenta bom resultado para a produção de "heavy oil" por este micro-organismo. O meio é composto por $5 \%(\mathrm{~m} / \mathrm{v})$ de sacarose, $0,06 \%(\mathrm{~m} / \mathrm{v}) \mathrm{de}$ peptona, 0,04\% (m/v) de extrato de levedura, 0,5\% (m/v) de $\mathrm{K}_{2} \mathrm{HPO}_{4}, 0,04 \%(\mathrm{~m} / \mathrm{v})$ de $\mathrm{MgSO}_{4} .7 \mathrm{H}_{2} \mathrm{O}$ e $0,1 \%(\mathrm{~m} / \mathrm{v})$ de $\mathrm{NaCl}$. Este mesmo meio foi utilizado em outros trabalhos para a produção de biossurfactantes e mostrou-se o mais adequado quando comparado com outras composições (PRICE et al., 2013; MANITCHOTPISIT et al., 2012; MANITCHOTPISIT et al., 2014; LEATHERS et al., 2015).

Observou-se que o meio de cultivo utilizado possui uma alta proporção $\mathrm{C} / \mathrm{N}$, o que está de acordo com o relatado por Casas e Ochoa (1999) e Albrecht e colaboradores (1996). Esses autores explicaram como a proporção $\mathrm{C} / \mathrm{N}$ alta favorece a biossíntese de biossurfactantes. Como o teste de espalhamento da gota foi o teste que apresentou maior sensibilidade para avaliação da produção do biossurfactante, além de apresentar uma boa correlação entre o halo formado e a concentração do biossurfactante (YOUSSEF et al., 2004), este teste foi escolhido para avaliação da produção de biossurfactante por Aureobasidium pullulans LB 83 em FES.

Para o estudo exploratório avaliou-se o espalhamento da gota, o $\mathrm{pH}$ e a estimativa da contagem de células após a extração da FES a cada 24 h durante 168 h. Os resultados de valores de pH em função do tempo de cultivo estão representados no Figura 12.

Figura 12 - Avaliação do pH durante a fermentação em estado sólido utilizando A. pullulans LB 83

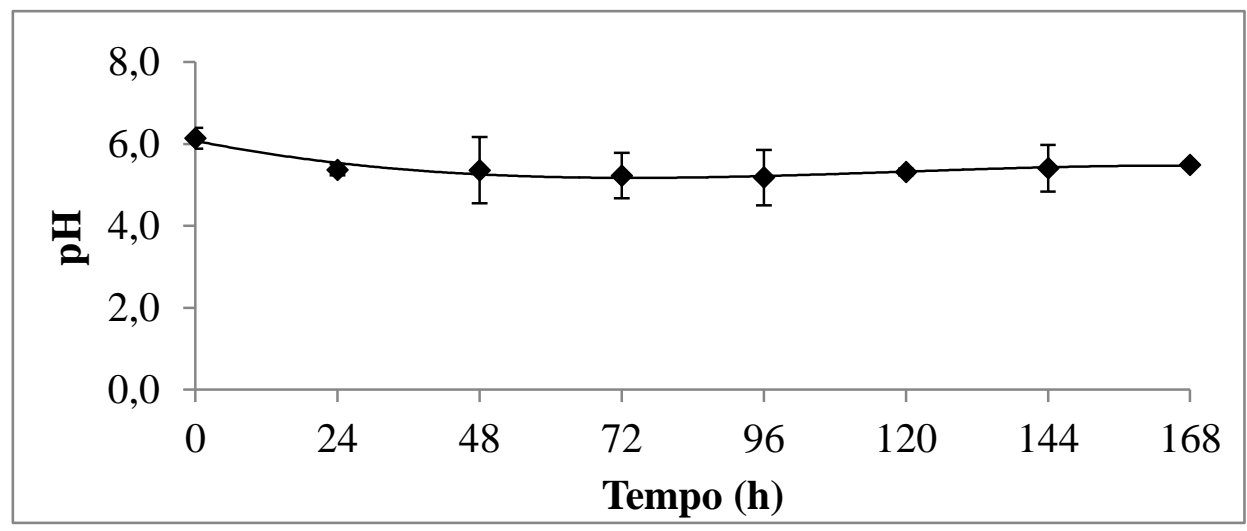

Fonte: Arquivo pessoal. 
De acordo com a Figura 12, observa-se que o pH do tempo inicial $(6,14)$ foi reduzido após 24 h de fermentação e se manteve praticamente constante (em média 5,4) durante todo o processo. Neste cultivo, não foi adicionada nenhuma solução tampão, entretanto, pode ter ocorrido ação tamponante de fontes orgânicas de nitrogênio, que diferentemente de fontes inorgânicas de nitrogênio, não proporcionam alterações bruscas de pH. O abaixamento inicial do $\mathrm{pH}$ pode ter sido provocado por alguns metabólitos ácidos produzidos por A. pullulans, como ácido glucônico e ácido málico e polimálico (ANASTASSIADIS; REHM, 2006; ZOU et al., 2013). O valor de pH durante a fermentação é um parâmetro importante, pois a forma morfológica deste fungo leveduriforme depende, entre outros fatores, do $\mathrm{pH}$ do meio (JADHAV; GAWAY, 2013).

A estimativa do crescimento celular durante a FES (obtida conforme item 4.12.6) está apresentada na Tabela 14.

Tabela 14 - Estimativa da concentração celular durante a fermentação. *A estimativa realizada considerando a concentração celular retida no bagaço (baseada na concentração celular inicial da fermentação $\left(1 \times 10^{6}\right)$ e a obtida após extração da amostra, determinada na Câmara Agasse-Lafont.

\begin{tabular}{|c|c|c|c|c|}
\hline Amostra & $\begin{array}{c}\text { Concentração celular } \\
\left(10^{5} \mathrm{cel} / \mathrm{mL}\right)\end{array}$ & $\begin{array}{c}\text { Concentração } \\
\text { celular teórica } \\
\left(10^{5} \mathrm{cel} / \mathrm{mL}\right)\end{array}$ & $\begin{array}{l}\text { Células retidas } \\
\left(10^{5} \mathrm{cel} / \mathrm{mL}\right)^{*}\end{array}$ & $\begin{array}{l}\text { Estimativa } \\
\left(10^{5} \mathrm{cel} / \mathrm{mL}\right)^{*}\end{array}$ \\
\hline Branco & 0,00 & 0,0 & 0,0 & 0,0 \\
\hline 0 & $4,48 \pm 0,33$ & 10 & 5,52 & $10 \pm 0,33$ \\
\hline 24 & $298,4 \pm 9,1$ & - & 5,52 & $303,92 \pm 9,1$ \\
\hline 48 & $289,6 \pm 29,9$ & - & 5,52 & $295,12 \pm 29,9$ \\
\hline 72 & $624 \pm 79,1$ & - & 5,52 & $629,52 \pm 79,1$ \\
\hline 96 & $688 \pm 33,3$ & - & 5,52 & $693,52 \pm 33,3$ \\
\hline 120 & $688 \pm 27,7$ & - & 5,52 & $693,52 \pm 27,7$ \\
\hline 144 & $656 \pm 90,5$ & - & 5,52 & $661,52 \pm 90,5$ \\
\hline 168 & $784 \pm 79,2$ & - & 5,52 & $789,52 \pm 79,2$ \\
\hline
\end{tabular}

Fonte: Arquivo pessoal.

Uma das maiores dificuldades na FES é justamente a determinação da concentração celular (THOMAS et al., 2013). Alguns métodos têm sido propostos como a determinação indireta (pela dosagem de componentes da célula, por exemplo $\mathrm{N}$-acetil-D-glicosamina ou ergosterol) (AGUIRRE et al., 2014; FERNANDEZ et al., 2011) e o quociente de respiração 
(usado em biorreatores que correlacionam as medidas concentração de $\mathrm{CO}_{2}$ com o crescimento celular) (MAZZUTI et al., 2010). Como o presente estudo foi somente exploratório para ter uma noção do perfil do crescimento microbiano na FES, foi utilizada a contagem de células extraídas da FES descontando-se a concentração retida após a extração no tempo inicial de fermentação. Sabe-se que esta medida não é exata e que a concentração celular real pode ter sido diferente da estimada, entretanto pode-se observar na Figura 13 o perfil do crescimento celular baseado nas concentrações estimadas de célula.

Figura 13 - Perfil de crescimento celular de A. pullulans LB 83 na fermentação em estado sólido utilizando os valores estimados de concentração celular.

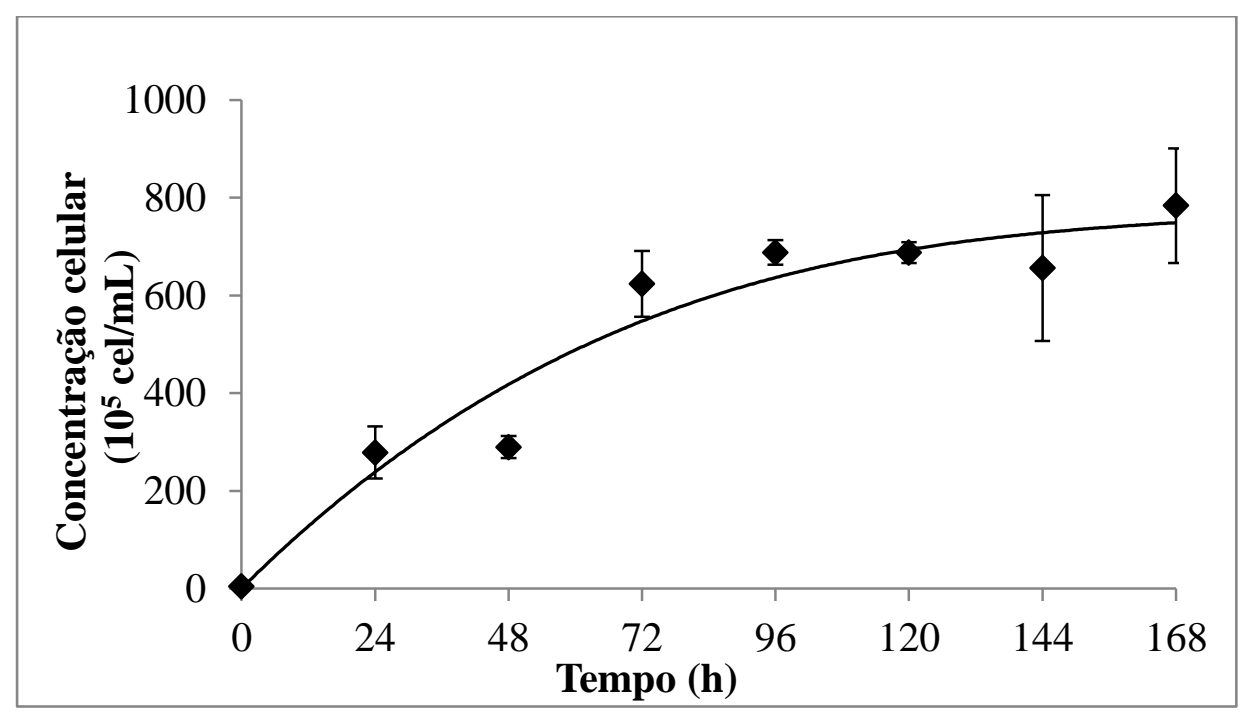

Fonte: Arquivo pessoal.

De acordo com a Figura 13, o perfil estimado do crescimento celular indicou maior velocidade de crescimento até 72 h. Pode-se observar que, após esse período, o microorganismo atingiu a fase estacionária de crescimento.

Com relação à produção de biossurfactantes, os resultados com os diâmetros da abertura do halo no teste de espalhamento da gota estão apresentados na Figura 14. Sabe-se que o diâmetro do halo está diretamente relacionado com a concentração do biossurfactante, por isso, estes valores foram utilizados para avaliar a produção de biossurfactantes durante a FES (YOUSSEF et al., 2004). 
Figura 14 - Resultados da abertura do halo no teste de espalhamento da gota durante a fermentação em estado sólido utilizando A. pullulans LB 83

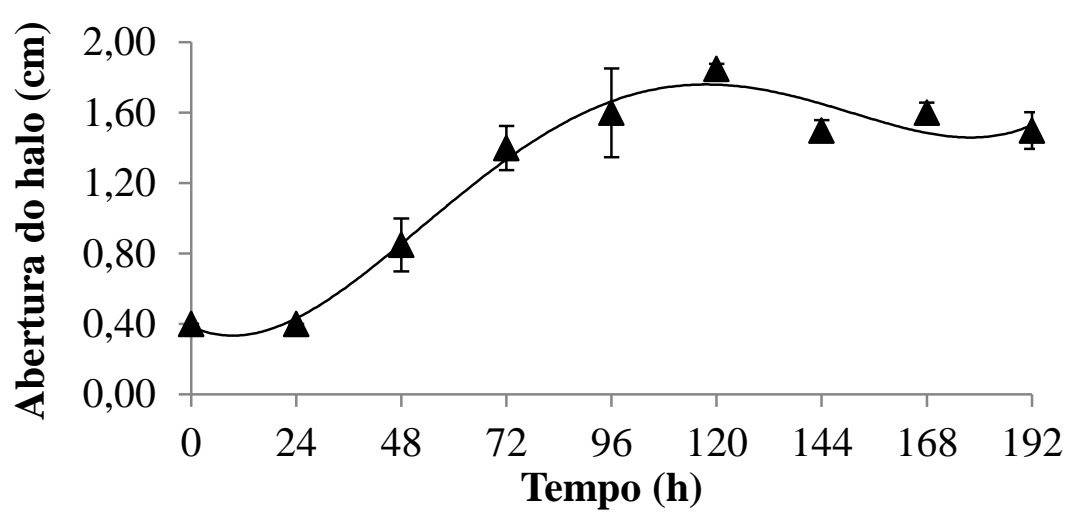

Fonte: Arquivo pessoal.

De acordo com a Figura 14, observa-se que a máxima produção de biossurfactantes ocorreu no tempo de $120 \mathrm{~h}$ (tensoatividade máxima 1,9 cm), uma vez que apresentou maior abertura do halo no teste de espalhamento da gota. Observa-se ainda que a partir de $144 \mathrm{~h}$ praticamente não houve alteração na abertura do halo, indicando que não houve aumento da produção de biossurfactantes após este período.

Verifica-se ainda que a produção de biossurfactantes ocorreu associada ao crescimento. A correlação existente entre a concentração celular e a atividade tensoativa obtidas durante a FES utilizando A. pullulans LB 83 é apresentada na Figura 15.

Figura 15 - Correlação entre a concentração celular e a atividade tensoativa (avaliada pela abertura do halo no teste de espalhamento da gota) obtidos durante a FES sólido utilizando A. pullulans LB 83

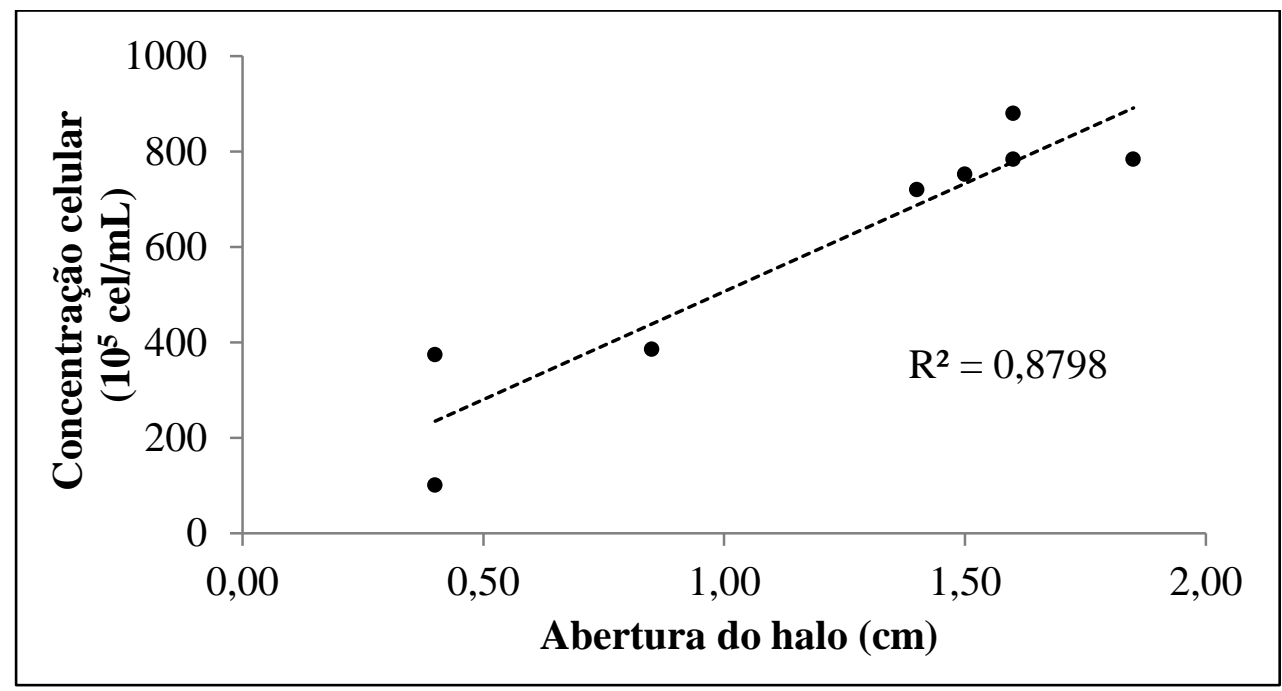

Fonte: Arquivo pessoal. 
Como observado na Figura 15, uma correlação positiva $\left(\mathrm{R}^{2}=0,88\right)$ foi observada, o que confirma que o biossurfactante foi produzido associado ao crescimento microbiano. Oliveira e colaboradores (2013), ao avaliarem a cinética de produção de biossurfactantes por Bacillus subtilis LAMI005, observaram que a produção de biossurfactantes por este micro-organismo também ocorreu associada ao crescimento celular. Entretanto, Ron e Rosenberg (2001) relataram que a maioria dos biossurfactantes é liberada no meio de cultura durante o estado estacionário ou na fase final de crescimento exponencial do micro-organismo produtor, sendo um metabólito secundário. Por tanto, pode-se constatar que esta característica depende do micro-organismo utilizado.

\subsection{Avaliação da utilização do bagaço de cana-de-açúcar como fonte de carbono} na FES pela levedura Aureobasidium pullulans LB 83

$\mathrm{Na}$ fermentação em estado sólido, o suporte pode ser constituído por um substrato naturalmente úmido ou por uma matriz inerte capaz de absorver os nutrientes que se encontram em solução reproduzindo as condições de baixa atividade de água e alta transferência de oxigênio (SOCCOL et al., 2002). O bagaço de cana-de-açúcar pode ser utilizado nas duas situações, sendo ele próprio a fonte de carbono ou um substrato inerte de suporte umidificado com os nutrientes necessários ao micro-organismo na FES (CAMILIOS NETO et al., 2011).

O bagaço utilizado no presente trabalho não passou por nenhum tipo de pré-tratamento e, portanto, para que a levedura o utilize como substrato ela deve ser capaz de produzir enzimas lignocelulolíticas capazes de expor os açúcares do bagaço e torna-los disponíveis para a fermentação (CADETE, 2009).

Para a avaliação da produção de enzimas degradadoras de material lignocelulósico pela levedura Aureobasidium pullulans SSS33 foram realizados inicialmente testes em placa conforme a metodologia já descrita (item 4.12.10, item 4.12.11, e item 4.12.12). A levedura apresentou resultados positivos para os testes de celulases (teste utilizando CMC como substrato), hemicelulases (teste utilizando xilana como substrato) e polifenol oxidases (teste utilizando ácido tânico como substrato) (Figura 16). 
Figura 16 - Resultados dos testes em placa da produção de celulases $\left(\mathrm{A}^{*}\right)$, xilanases $\left(\mathrm{B}^{*}\right)$ e polifenol oxidases (C) por Aureobasidium pullulans LB 83

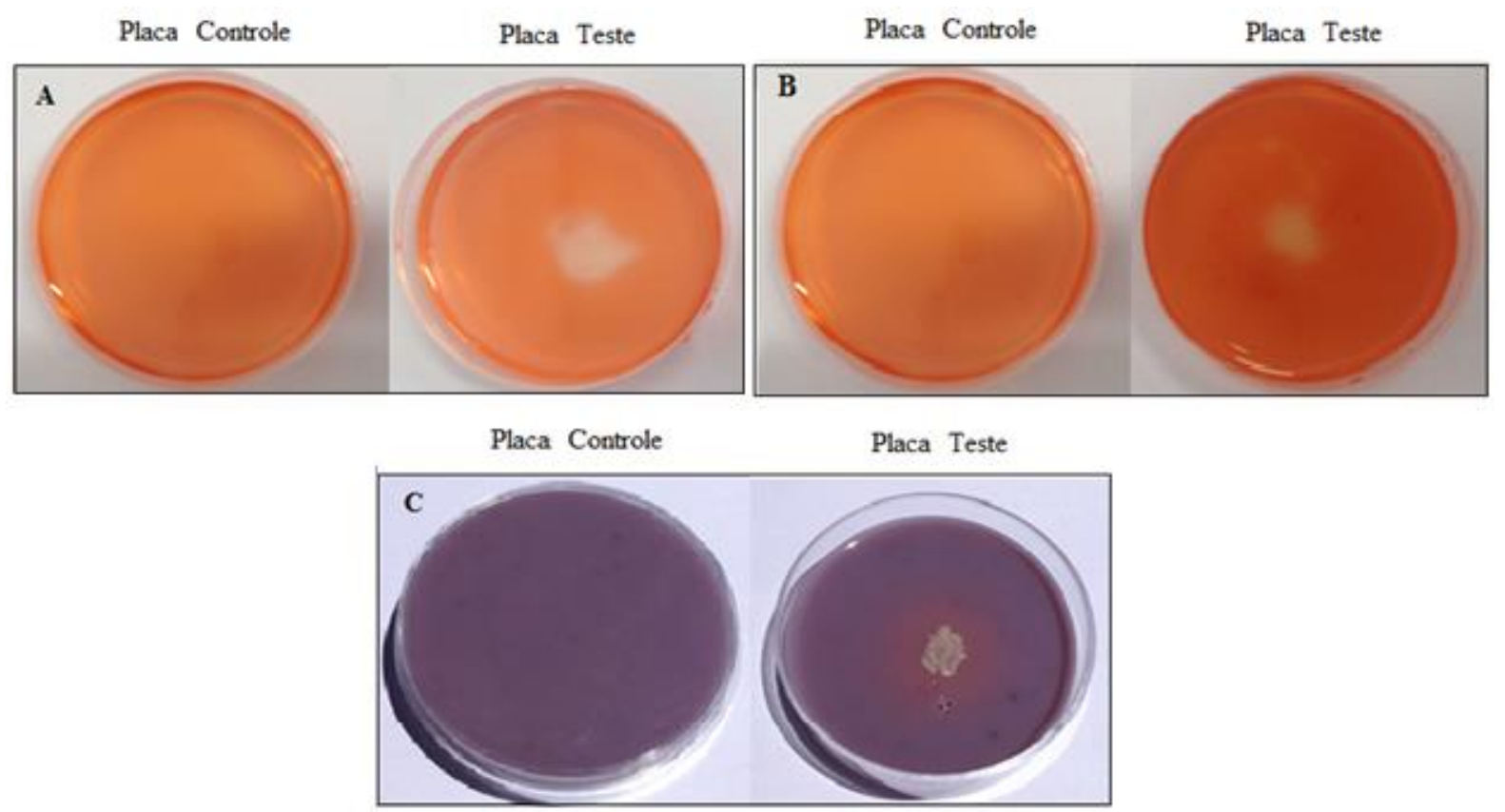

*resultados após a adição do reagente vermelho do congo. Fonte: Arquivo pessoal.

Estes resultados estão de acordo com os relatados por Arcuri e colaboradores (2014), os autores responsáveis pelo isolamento da levedura utilizada no presente trabalho. Os autores relataram resultados positivos para os testes em placa para celulases, amilase, poligalacturonase, pectinase lipase e xilanase. Entretanto foram relatados resultados negativos para ligninases (usando testes com azul de remazol brilhante e guaiacol). O teste realizado no presente trabalho para polifenol oxidases utilizou substrato diferente daqueles testados por Arcuri e colaboradores (2014), o que pode justificar a diferença entre os resultados qualitativos. Também é importante ressaltar que, de acordo com Pointing (1999), o resultado positivo no teste utilizando polifenol oxidase indica uma atividade geral da polifenol oxidase e não é específica para enzimas ligninolíticas. Por isso, este resultado divergiu daqueles realizados por Arcuri e colaboradores (2014) utilizando guaiacol e azul de remazol brilhante, testes mais específicos para enzimas ligninolíticas.

Os testes em placa realizados tiveram caráter qualitativo para avaliar a possível utilização do bagaço de cana-de-açúcar como fonte de carbono pela levedura. Para avaliar se a levedura excreta de fato essas enzimas durante a FES, testes de atividade enzimática específicos foram realizados utilizando os extratos da fermentação. 


\subsubsection{Avaliação das atividades celulolítica e xilanolítica na FES}

Após a verificação da capacidade de produção das enzimas celulase, xilanase e polifenol oxidases em placa pela levedura A. pullulans LB 83, foram realizados testes de atividade enzimática de celulases e hemicelulases em fermentação em estado sólido. Para tanto, foi utilizado o extrato bruto da FES, conduzidas nas condições estabelecidas para a produção de biossurfactantes utilizando bagaço de cana-de-açúcar como suporte.

Nas condições experimentais utilizadas, não foram detectadas atividades de celulases totais (FPA) e xilanases. A atividade de celulases totais não pôde ser detectada porque a reta formada pelos pontos do inverso das diferentes diluições testadas (1:1, 1:2, 1:4 e 1:6) não atingiu o valor de $2 \mathrm{mg}$ de glicose no gráfico (relacionando o inverso das diluições da enzima pela quantidade de glicose liberada) utilizado para calcular o valor da atividade na metodologia de Ghose (1987), descrita no ítem (4.10.13). A atividade de xilanases não foi detectada porque os valores de absorbância das amostras dos extratos brutos não foram maiores que o valor de absorbância do controle da respectiva amostra, indicando que não houve liberação de xilose.

Em condições diferentes de FES, Leites e colaboradores (2007) relataram a produção de celulases e hemicelulases pela levedura Aureobasidium pullulans ER-16, utilizando como substratos farelo de trigo, farelo de soja, casca de soja e espiga de milho. Os autores relataram que, entre os substratos avaliados, o farelo de trigo apresentou a maior produção enzimática (1,05 U/mL endoglucanase; 1,3 U/mL $\beta$-glicosidase e 5,0 U/mL xilanase, atividade de celobiohidrolase não foi detectada). É importante destacar que na metodologia utilizada pelos autores nenhuma fonte de carbono foi adicionada, somente um meio mineral foi utilizada como solução umedecedora. No presente trabalho, além de testar um substrato diferente (bagaço de cana-de-açúcar), utilizou-se $50 \mathrm{~g} / \mathrm{L}$ de fonte de carbono (sacarose), o que pode ter inibido a produção enzimática.

Optou-se por não avaliar separadamente as enzimas do complexo celulolítico, uma vez que para a disponibilização de açúcares fermentescíveis a partir do bagaço de cana-de-açúcar utilizado como substrato a levedura precisaria produzir um conjunto de enzimas do complexo, sendo a metodologia de FPU a mais adequada para avaliar esta capacidade.

A ação de celulases e hemicelulases é de importância fundamental para a obtenção de açúcares fermentescíveis da biomassa lignocelulósica (LEITES et al., 2007). O fato de não serem detectadas atividades celulolíticas e hemicelulolíticas no extrato da FES suporta a hipótese de que o bagaço de cana-de-açúcar é utilizado somente como suporte e não como fonte 
de carbono no processo de produção de biossurfactante por Aureobasidium pullulans LB 83 em FES.

Camilios Neto e colaboradores (2011) utilizaram o bagaço de cana-de-açúcar como um suporte essencialmente inerte para a produção de biossurfactantes pela bactéria Pseudomodas aeruginosas. Os autores adicionaram como fonte de carbono glicerol e observaram que a utilização de bagaço de cana-de-açúcar é apropriada para a produção do biossurfactante do tipo raminolipídeo por proporcionar níveis de produção razoáveis e grande facilidade de extração do tensoativo, além de ser abundante, disponível e de baixo custo.

\subsection{Estudo das condições importantes para o processo de produção de biossurfactante pela levedura selecionada}

\subsubsection{Avaliação de diferentes fontes de carbono}

Para avaliação do uso de diferentes fontes de carbono, realizaram-se testes em paralelo em FES e fermentação submersa. Foi feito o estudo em fermentação submersa devido à maior facilidade para se avaliar o crescimento celular e o consumo das fontes de carbono. O teste para avaliar a produção de biossurfactantes (teste de espalhamento da gota) foi feito nos dois tipos de cultivo. Foram testadas as fontes de carbono glicose, sacarose, manose, arabinose e xilose. Essas fontes de carbono foram escolhidas para o teste porque, de acordo com relatos na literatura, a parte hidrofílica da molécula do biossurfactante produzido pelo A. pullulans pode ser composta pelos polióis manitol ou arabitol (KUROSAWA et al., 1994) e a síntese destes polióis podem ocorrer a partir de frutose (presente na sacarose) e, pelas vias de gliconeogênese e glicólise, a glicose pode ser convertida a frutose para ser então utilizada na síntese do poliol (LEWIS; SMITH, 1967). A xilose e a arabinose pela via das pentoses fosfato (PPP) também pode ser convertida a frutose e consequentemente, em teoria poderia seguir a síntese de manitol e arabitol. É importante ressaltar que a síntese destes polióis depende também do equilíbrio redox no meio intracelular.

O teste para avaliar a produção de biossurfactantes por A. pullulans LB 83 utilizando arabinose e xilose também é interessante por estes carboidratos estarem presentes na fração hemicelulósica do bagaço de cana-de-açúcar, assim como a glicose, presente na fração celulósica. No caso de o micro-organismo ser produtor de enzimas e capaz de acessar estes carboidratos, esses poderiam ser utilizados também da síntese da molécula de interesse. 
A FS foi realizada testando as fontes de carbono separadamente. Foram observadas modificações no aspecto do meio de cultivo durante a fermentação, tanto na cor quanto em sua viscosidade. $\mathrm{O}$ aumento da viscosidade pode ser explicado devido à co-produção de pululana, um exopolissacaríseo (SUTHERLAND 1998). No processo de produção da pululana o $A$. pullulans pode produzir pigmentos de coloração preta, marrom e verde, sendo a melanina o principal deles (MANITCHOTPISIT et al., 2011). Na Figura 17 pode-se observar a mudança de coloração com o tempo de cultivo nas diferentes fontes de carbono.

Figura 17 - Mudança de coloração do cultivo de A. pullulans SSS 33 nos tempos de 24 h e 168 h em diferentes fontes de carbono (glicose, manose, sacarose, arabinose e xilose)

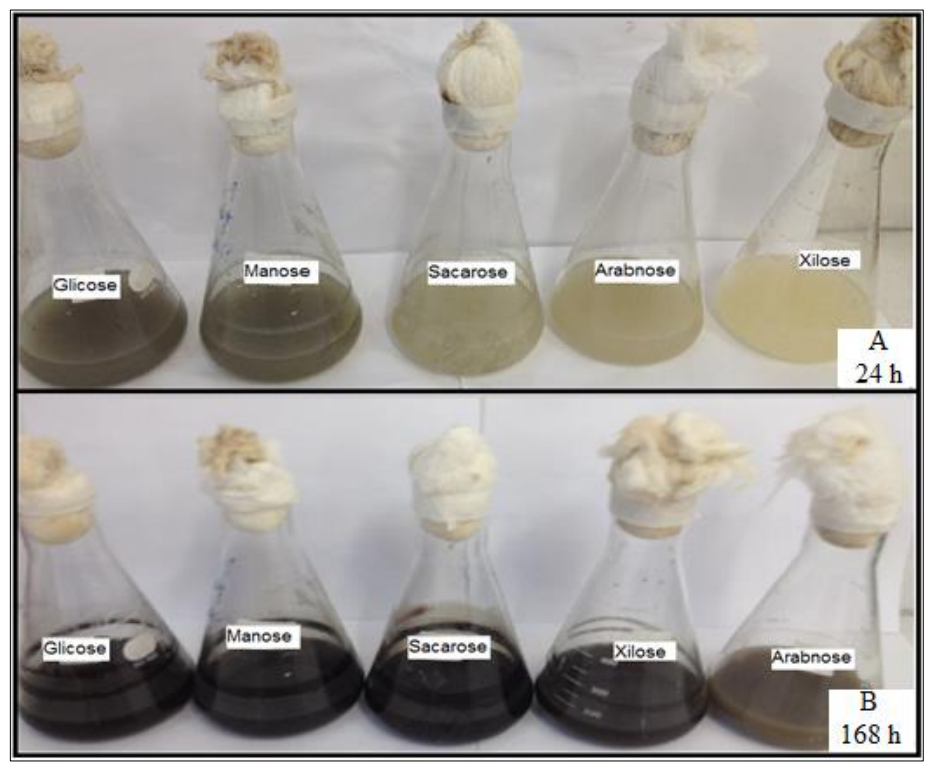

A: mudança de coloração após 24 h; B: mudança de coloração após 168 h. Fonte: Arquivo pessoal.

De acordo com a Figura 17, constata-se que os cultivos utilizando glicose e manose apresentaram maior escurecimento após $24 \mathrm{~h}$, entretanto, após $168 \mathrm{~h}$ todos os cultivos apresentaram-se escuros, apenas o cultivo com arabinose apresentou uma coloração levemente mais clara.

O consumo dos açúcares durante o tempo de cultivo está apresentado na Figura 18, onde se observa que a sacarose foi rapidamente assimilada, chegando a ser consumida totalmente após $48 \mathrm{~h}$ de fermentação. Este fato ocorreu porque a levedura A. pullulans produz a enzima invertase, que hidrolisa a sacarose em glicose e frutose (Wei et al., 2017). A comprovação da atuação da enzima invertase pode ser verificada pelas análises em HPLC, onde se observou a redução nas concentrações da sacarose concomitantemente ao aumento das concentrações de glicose nos cultivos preparados com sacarose como fonte de carbono (Tabela 15). 
Figura 18 - Concentração de diferentes fontes de carbono durante o cultivo de Aureobasidium pullulans SSS33 em função do tempo de fermentação submersa

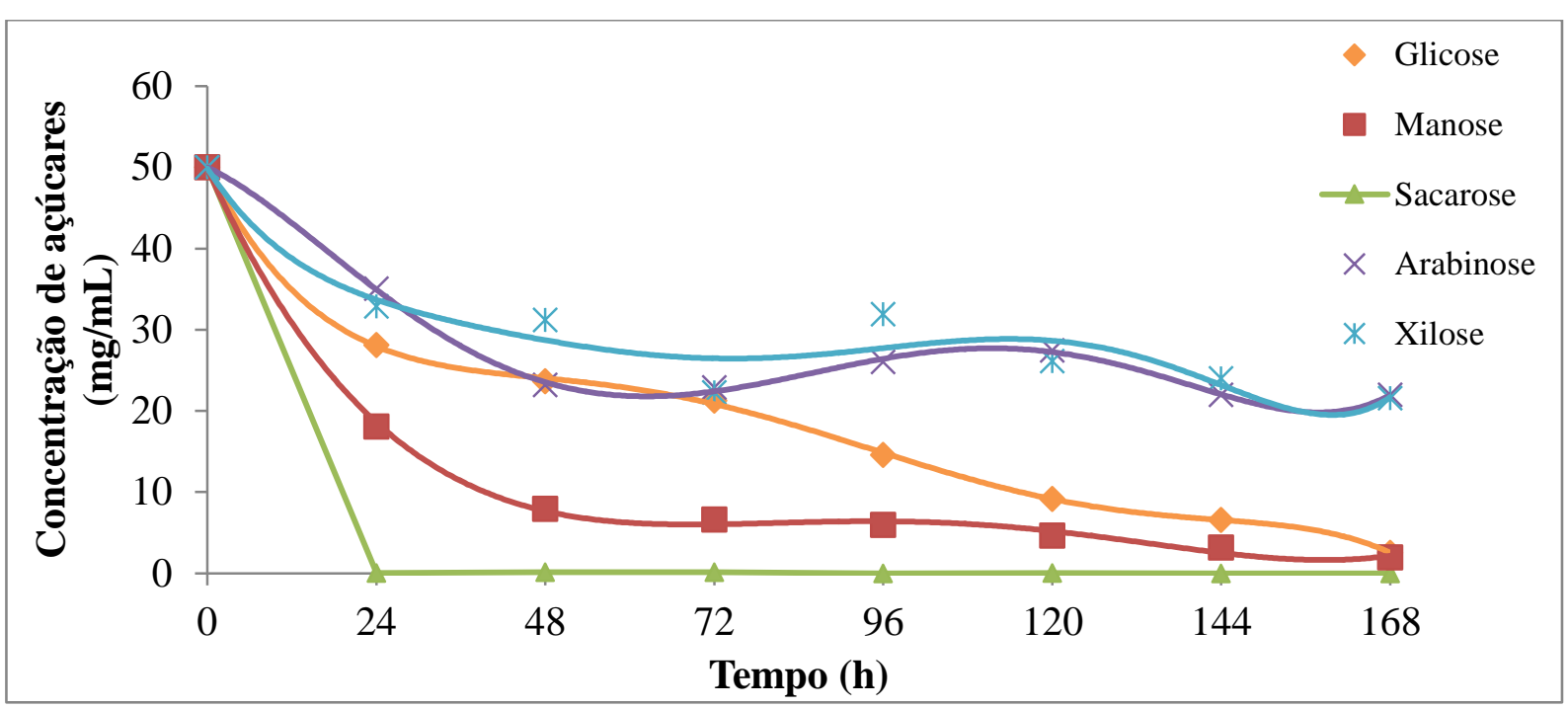

Fonte: Arquivo pessoal.

Tabela 15 - Concentração de sacarose e glicose durante a fermentação nos cultivos preparados com sacarose como única fonte de carbono

\begin{tabular}{ccccccccc}
\hline \multirow{2}{*}{ Açúcar } & \multicolumn{8}{c}{ Tempo de fermentação (h) } \\
& $\mathbf{0}$ & $\mathbf{2 4}$ & $\mathbf{4 8}$ & $\mathbf{7 2}$ & $\mathbf{9 6}$ & $\mathbf{1 2 0}$ & $\mathbf{1 4 4}$ & $\mathbf{1 6 8}$ \\
\hline Sacarose $(\mathrm{mg} / \mathrm{mL})$ & 48,3 & 0,36 & 0,10 & 0,12 & 0,12 & 0,00 & 0,03 & 0,00 \\
Glicose $(\mathrm{mg} / \mathrm{mL})$ & 0,52 & 0,41 & 2,22 & 10,12 & 7,46 & 2,28 & 0,15 & 0,53 \\
\hline
\end{tabular}

Fonte: Arquivo pessoal.

Ainda de acordo com a Figura 18, observa-se que os açúcares glicose, sacarose e manose são totalmente consumidos na fermentação, enquanto arabinose e xilose tem apenas metade da sua concentração inicial consumida após o oitavo dia de fermentação. Sabe-se que a xilose e a arabinose são açúcares pentoses e seu metabolismo depende da via PPP e por isso sua assimilação metabólica é mais complexa, enquanto glicose, sacarose e manose possuem mais fácil assimilação.

Avaliando o crescimento celular nos cultivos utilizando diferentes fontes de carbono (Figura 19), pode-se observar que, de maneira geral, nos tempos analisados, as concentrações celulares foram bem próximas para as diferentes fontes de carbono até 96 h. Entretanto, não foram retiradas amostras em curtos períodos no tempo inicial da fermentação, que demonstrariam diferentes fases lag, de acordo com o tipo de carboidrato do meio, indicando o período de adaptação metabólica. Possivelmente, esta fase seria ainda maior nos cultivos com 
arabinose e xilose, por se tratarem de açúcares pentoses que exigem mecanismos e vias metabólicas mais complexas para sua assimilação.

Figura 19 - Concentração celular de Aureobasidium pullulans SSS33 em função do tempo de fermentação submersa em diferentes fontes de carbono

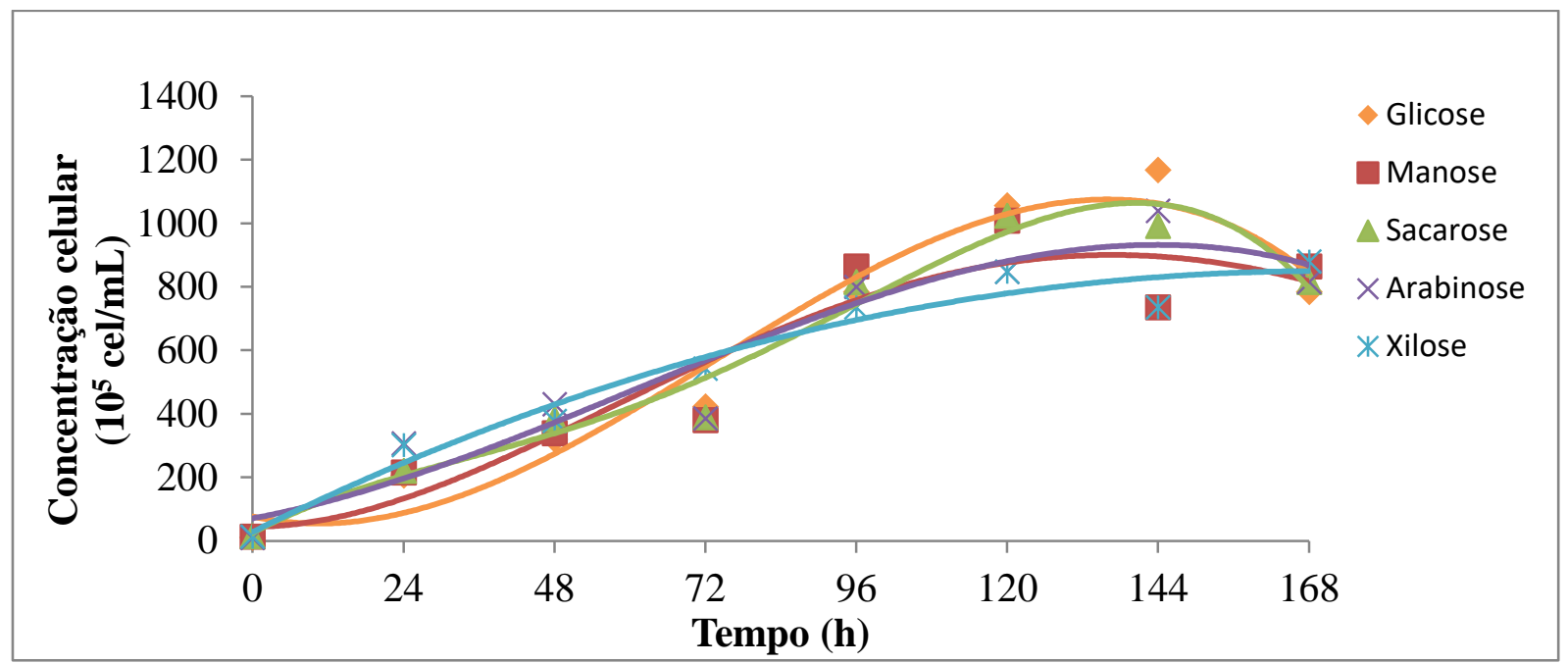

Fonte: Arquivo pessoal.

Observa-se pelas linhas de tendência apresentadas na Figura 19 que o micro-organismo atingiu a fase estacionária de crescimento após 120 h para todas as fontes de carbono testadas. Este resultado se difere daquele encontrado para o perfil de crescimento na FES, em que a fase estacionária foi observada após $72 \mathrm{~h}$. Essa alteração no perfil celular se deve, possivelmente, às diferenças na forma de condução dos processos de FS e FES, uma vez que o ambiente fornecido ao micro-organismo na FES restringe a disponibilidade de água e modifica a transferência de oxigênio (MITCHELL et al., 2006), fatores estes que podem influenciar no crescimento celular.

Os resultados da produção de biossurfactante nas diferentes fontes de carbono podem ser observados na Tabela 16. 
Tabela 16 - Valores de espalhamento da gota $(\mathrm{cm})$ em função do tempo nas diferentes fontes de carbono testadas para a produção de biossurfactantes por A. pullulans LB 83 em fermentação submersa

\begin{tabular}{cccccc}
\hline \multirow{2}{*}{ Tempo (h) } & \multicolumn{5}{c}{ Espalhamento da gota (cm) } \\
\cline { 2 - 6 } & Glicose & manose & sacarose & arabinose & Xilose \\
\hline 0 & $0,0 \pm 0,0$ & $0,0 \pm 0,0$ & $0,0 \pm 0,0$ & $0,0 \pm 0,0$ & $0,0 \pm 0,0$ \\
24 & $0,6 \pm 0,1$ & $0,0 \pm 0,0$ & $0,5 \pm 0,1$ & $0,4 \pm 0,1$ & $0,2 \pm 0,2$ \\
48 & $3,8 \pm 1,1$ & $0,9 \pm 0,1$ & $2,1 \pm 1,0$ & $1,0 \pm 0,3$ & $0,9 \pm 0,3$ \\
72 & $\mathbf{4 , 5} \pm \mathbf{0 , 6}$ & $1,5 \pm 0,5$ & $\mathbf{6 , 0} \pm \mathbf{0 , 8}$ & $2,5 \pm 0,5$ & $1,7 \pm 0,4$ \\
96 & $3,1 \pm 1,0$ & $2,5 \pm 0,6$ & $4,8 \pm 0,8$ & $3,3 \pm 0,9$ & $2,5 \pm 0,1$ \\
120 & $4,1 \pm 0,0$ & $2,2 \pm 0,1$ & $4,9 \pm 0,2$ & $3,6 \pm 1,4$ & $2,5 \pm 0,2$ \\
144 & $4,5 \pm 0,6$ & $3,7 \pm 0,9$ & $3,5 \pm 1,8$ & $3,5 \pm 1,3$ & $\mathbf{2 , 7} \pm \mathbf{0 , 4}$ \\
168 & $4,2 \pm 0,8$ & $\mathbf{4 , 3} \pm \mathbf{0 , 7}$ & $3,1 \pm 2,5$ & $\mathbf{4 , 0} \pm \mathbf{0 , 9}$ & $2,5 \pm 0,7$ \\
\hline
\end{tabular}

Fonte: Arquivo pessoal.

Verifica-se que a levedura foi capaz de produzir biossurfactantes a partir de todos os carboidratos testados, entretanto algumas dessas fontes de carbono apresentaram melhores resultados (Tabela 16). Os cultivos utilizando glicose e sacarose como fonte de carbono foram os que apresentaram os melhores resultados em menor tempo (72 h), isso ocorreu porque estes carboidratos possuem assimilação metabólica mais simples. Os cultivos utilizando manose e arabinose apresentaram o seu maior resultado de produção de biossurfactantes no tempo de 168 h. Por outro lado, os cultivos que utilizaram xilose obtiveram melhores resultados após 144 h. Deve-se observar que as fontes de carbono xilose e arabinose foram aquelas de menor assimilação pela levedura (Figura18), o que pode justificar os menores resultados de produção de biossurfactantes para estes açúcares.

Na Tabela 17 são apresentados os resultados de Ta e $\mathrm{Q}_{\mathrm{Ta}}$ para cada fonte de carbono e as suas médias (de acordo com o teste Tukey), destacando aquelas que apresentaram diferença estatística por letras minúsculas diferentes. De acordo com os resultados, quanto à tensoatividade (Ta) não há diferença significativa entre os resultados obtidos quando manose, glicose ou arabinose são utilizadas, entretanto o resultado obtido quando utilizou-se xilose foi significativamente menor $(p>0,05)$. As fermentações utilizando sacarose apresentaram resultados significativamente maiores de Ta que as demais fontes de carbono. Com relação à produtividade em tensoatividade $\left(\mathrm{Q}_{\mathrm{Ta}}\right)$ a utilização de sacarose também apresentou resultado médio significativamente melhor $(\mathrm{p}>0,05)$ que as demais fontes de carbono. Não foram 
observadas diferenças significativas quanto à $\mathrm{Q}_{\mathrm{Ta}}$ entre a utilização de glicose, manose, arabinose e xilose, as quais apresentaram menores médias.

Tabela 17 - Valores de maior tensoatividade $(\mathrm{Ta})$ e produtividade em tensoatividade $\left(\mathrm{Q}_{\mathrm{Ta}}\right)$ para diferentes fontes de carbono (glicose, manose, sacarose, arabinose e xilose) e suas médias (teste de Tukey a $95 \%$ de confiança).

\begin{tabular}{|c|c|c|c|c|c|}
\hline Tensoatividade & glicose & manose & sacarose & arabinose & xilose \\
\hline $\mathrm{Ta}(\mathrm{cm})$ & $4,5 \pm 0,6 \mathrm{~b}$ & $4,3 \pm 0,6 b$ & $6,0 \pm 0,8 \mathrm{a}$ & $4,0 \pm 1,6 \mathrm{~b}$ & $2,5 \pm 0,2 \mathrm{c}$ \\
\hline $\mathrm{CV}(\%)$ & & & 25,42 & & \\
\hline Erro padrão & & & 0,577 & & \\
\hline $\begin{array}{c}\text { Produtividade } \\
\text { em } \\
\text { tensoatividade }\end{array}$ & glicose & manose & sacarose & arabinose & xilose \\
\hline $\mathrm{Q}_{\mathrm{Ta}}(\mathrm{cm} / \mathrm{h})$ & $\begin{array}{c}3,1 \times 10^{-2} \\
\pm 0,4 \times 10^{-2} \mathrm{a}\end{array}$ & $\begin{array}{c}2,6 \times 10^{-2} \\
\pm 0,3 \times 10^{-2} \mathrm{a}\end{array}$ & $\begin{array}{c}8,3 \times 10^{-2} \\
\pm 1,1 \times 10^{-2} \mathrm{~b}\end{array}$ & $\begin{array}{c}2,4 \times 10^{-2} \\
\pm 0,5 \times 10^{-2} \mathrm{a}\end{array}$ & $\begin{array}{r}1,9 \times 10^{-2} \\
\pm 0,1 \times 10^{-2} \mathrm{a}\end{array}$ \\
\hline $\mathrm{CV}(\%)$ & & & 23,71 & & \\
\hline Erro padrão & & & $0,447 \times 10^{-2}$ & & \\
\hline
\end{tabular}

*Médias seguidas de letras distintas minúsculas nas linhas, indicam diferenças estatísticas $(p>0,05)$ pelo Teste de Tukey. Fonte: Arquivo pessoal.

Como descrito anteriormente, a produção dos polióis (parte polar do biossurfactante) a partir de arabinose e xilose depende da via PPP e depende do equilíbrio redox da célula (SILVA et al., 1994; ESCALANTE et al., 1990). O equilíbrio redox também é de grande importância para a produção do poliol a partir de manose. A síntese do poliol a partir de glicose e sacarose ocorre tendo como intermediário a frutose (liberada na clivagem da sacarose pela invertase e produzida a partir da glicose-6P pela ação da enzima glicose isomerase da via glicolítica). Portanto, observa-se que a rota metabólica utilizada pelo micro-organismo para a produção do poliol que constitui a parte polar do biossurfactante ocorre com maior fluxo a partir da frutose, como demonstrado na Figura 20 (GRAÇA et al., 2004). 
Figura 20 - Biossíntese de manitol a partir da sacarose e da glicose

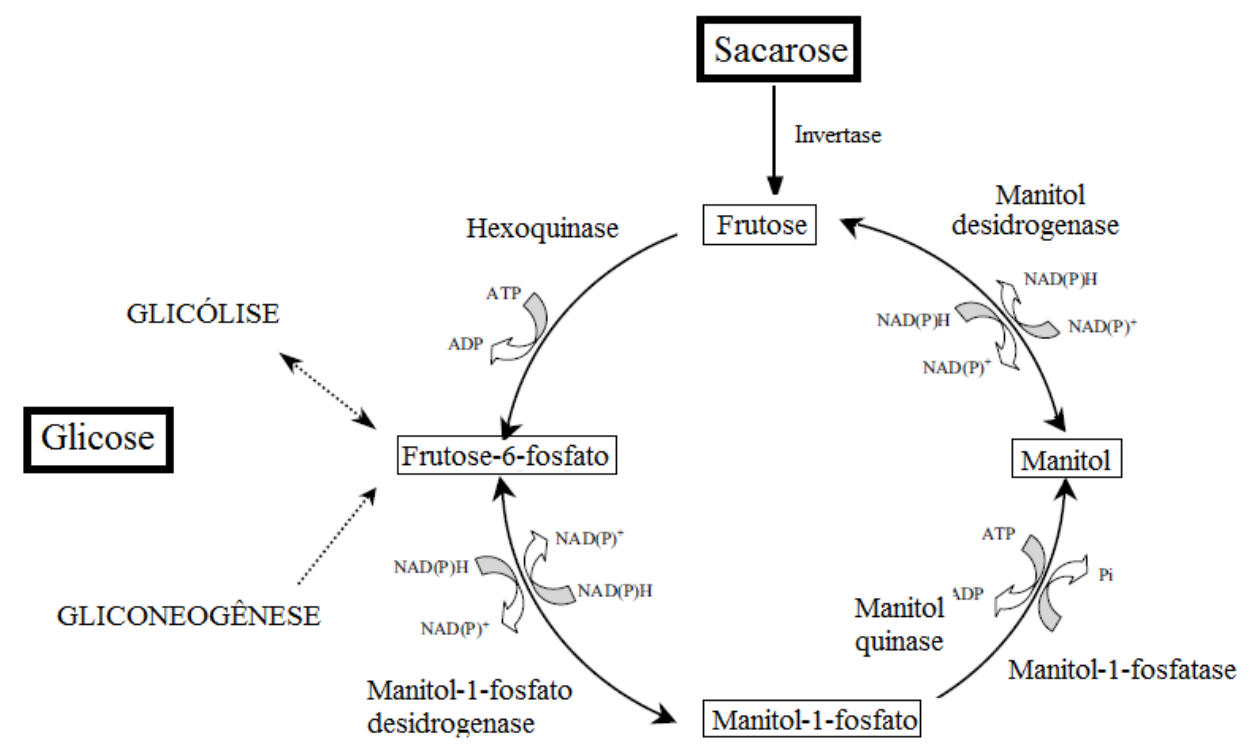

Fonte: Adaptado de GRAÇA et al., 2004.

Com relação ao metabolismo da produção da porção lipídica do biossurfactante produzido por A. pullulans (ácido 3,5-dihidroxidecanóico), Li e colaboradores (2015) relataram que sua biossíntese provavelmente ocorre de acordo com a via de hidroxi ácidos graxos em micro-organismo oleaginosos, descrita por Ratledge (2004) e Schumann e Hertweck (2006). De acordo com os autores, o ácido 3,5-dihidroxidecanóico pode ser sintetizado e regulado via policetídeo sintetase fúngica (PKS), sendo que as enzimas 3-cetoacil sintetase (KS) e 3cetoacil-ACP redutase (KR) possuem importante função na síntese desse ácido graxo. Assim, Zheng e colaboradores (2004) reportaram que, antes do ácido 3,5-dihidroxidecanóico se ligar ao manitol ou outro poliol, este ácido graxo deve ser antes convertido em 3,5-dihidroxidecanoilCoA em A. pullulans.

De acordo com Wei e colaboradores (2017), a levedura A. pullulans é capaz de produzir invertase extracelular. A ação desta enzima leva à liberação de frutose a partir da sacarose, a qual fica rapidamente disponível no meio para assimilação e síntese de bioprodutos. A rápida disponibilização de frutose a partir da sacarose justifica esta ser a fonte de carbono que apresentou melhores resultados para a produção de biossurfactantes por Aureobasidium pullulans, de acordo com a análise estatística (Tabela 17).

Na FES realizada utilizando diferentes fontes de carbono, a produção de surfactante foi analisada somente ao final da fermentação $(168 \mathrm{~h})$, utilizando o teste de espalhamento da gota. Na Tabela 18 são apresentados os resultados de Ta e Q Ta para cada fonte de carbono após 168 
h de cultivo, e as suas médias (de acordo com o teste Tukey), destacando aquelas que apresentaram diferença estatística por letras minúsculas diferentes

Tabela 18 - Valores de maior tensoatividade (Ta) para diferentes fontes de carbono (glicose, manose, sacarose, arabinose e xilose) e suas médias (teste de Tukey a 90\% de confiança) na fermentação em estado sólido utilizando bagaço de cana-de-açúcar como substrato

\begin{tabular}{cccccc}
\hline Experimento & glicose & manose & sacarose & arabinose & xilose \\
\hline $\begin{array}{c}\text { Tensoatividade } \\
(\mathrm{cm})\end{array}$ & $3,05 \pm 0,44 \mathrm{a}$ & $2,1 \pm 0,15 \mathrm{ab}$ & $3,25 \pm 0,73 \mathrm{a}$ & $2,6 \pm 0,36 \mathrm{ab}$ & $1,8 \pm 0,15 \mathrm{~b}$ \\
\hline $\mathrm{CV}(\%)(\mathrm{Ta})$ & & 24,99 & & \\
\hline Erro padrão & & 0,298 & & \\
\hline
\end{tabular}

*Médias seguidas de letras distintas minúsculas nas linhas, indicam diferenças estatísticas $(p>0,10)$ pelo Teste de Tukey. Fonte: Arquivo pessoal.

Observa-se na Tabela 18 que semelhantemente à fermentação submersa, os cultivos utilizando xilose obtiveram os menores valores de tensoatividade, e as fermentações utilizando sacarose e glicose obtiveram os maiores valores de tensoatividade na FES. Estes resultados apresentaram diferença significativa pelo teste de Tukey a um nível de $90 \%$ de confiança (Tabela 18).

Diferentemente da FS, na FES, a um nível de confiança de 95\% não foram observadas diferenças significativas entre a tensoatividade observada utilizando as diferentes fontes de carbono. A menor variação entre os valores observados na FES para diferentes fontes de carbono pode ser explicada porque somente foram avaliadas as amostras com $168 \mathrm{~h}$ de cultivo, não necessariamente na resposta tensoativa máxima (Ta), como considerada na FS.

Assim, a sacarose foi empregada como fonte de carbono nas próximas etapas do trabalho para o processo fermentativo visando a produção de biossurfactantes por A. pullulans LB 83 .

5.6.2 Avaliação do uso de indutores na produção de biossurfactantes por Aureobasidium pullulans LB 83

O uso de indutores para o aumento da produção de biossurfactantes por diferentes micro-organismos tem sido uma estratégia utilizada em trabalhos relatados por diversos autores (CAMILIOS NETO et al., 2008; CAMILIOS NETO et al., 2011; DECESARO et al., 2013; BUENO et al., 2008). Entretanto, o uso de indutores na produção de biossurfactantes por Aureobasidium pullulans ainda não foi explorado. 
Os testes preliminares visando avaliar a ação do glicerol e óleo de soja como indutores da produção de biossurfactantes foram realizados por meio de fermentações submersas com as seguintes concentrações de fonte de carbono e indutores: sacarose $(50 \mathrm{~g} / \mathrm{L})$ e glicerol $(3 \% \mathrm{v} / \mathrm{v})$ (SG); sacarose (50 g/L) e óleo de soja (5 \% v/v) (SO); sacarose (50 g/L), óleo de soja (5\% v/v) e glicerol (3\% v/v) (SOG) e somente sacarose (50 g/L) (S) (fermentação controle). As concentrações utilizadas foram definidas de acordo com os valores de referência reportados na literatura para ação indutora, conforme relatado por Camilios Neto (2010).

A média dos valores de máxima tensoatividade e máxima produtividade em tensoatividade das fermentações utilizando indutores e fermentações controles estão apresentados na Tabela 19.

Tabela 19 - Média dos valores de máxima tensoatividade $(\mathrm{Ta})$ e produtividade em tensoatividade $\left(\mathrm{Q}_{\mathrm{Ta}}\right)$ das fermentações utilizando sacarose e glicerol (SG); sacarose e óleo de soja (SO); sacarose, óleo de soja e glicerol (SOG) e somente sacarose (S) (fermentação controle) para avaliação da ação indutora de óleo de soja e glicerol para a produção de biossurfactantes por Aureobasidium pullulans LB 83 em fermentação submersa

\begin{tabular}{|c|c|c|c|c|}
\hline Experimento & $\mathbf{S}$ (controle) & SG & SO & SGO \\
\hline Tensoatividade (cm) & $2,9 \pm 0,4 \mathrm{a}$ & $2,7 \pm 0,2 \mathrm{a}$ & $3,9 \pm 0,1 \mathrm{a}$ & $3,1 \pm 0,2 \mathrm{a}$ \\
\hline $\mathrm{CV}$ & \multicolumn{4}{|c|}{21,65} \\
\hline Erro padrão & \multicolumn{4}{|c|}{0,333} \\
\hline $\begin{array}{c}\text { Produtividade em } \\
\text { tensoatividade } \\
(\mathrm{cm} / \mathrm{h})\end{array}$ & $\begin{array}{r}0,020 \\
\pm 0,003 \mathrm{a}\end{array}$ & $\begin{array}{c}0,016 \\
\pm 0,001 \mathrm{a}\end{array}$ & $\begin{array}{r}0,023 \\
\pm 0,001 \mathrm{a}\end{array}$ & $\begin{array}{r}0,018 \\
\pm 0,001 \mathrm{a}\end{array}$ \\
\hline $\mathrm{CV}$ & \multicolumn{4}{|c|}{27,22} \\
\hline Erro padrão & \multicolumn{4}{|c|}{0,002} \\
\hline
\end{tabular}

Médias seguidas de letras distintas minúsculas nas linhas, indicam diferenças estatísticas ( $>>0,05)$ pelo Teste de Tukey. Fonte: Arquivo pessoal.

De acordo com a análise estatística (teste de Tukey a 95\% de confiança) dos resultados apresentados na Tabela 19, pôde-se observar que a adição de $3 \%$ (v/v) de glicerol e 5 \% (v/v) de óleo de soja e a utilização dos dois simultaneamente não levou a uma diferença significativa entre a média da máxima tensoatividade $(\mathrm{cm})$ e da produtividade em tensoatividade $(\mathrm{cm} / \mathrm{h})$ obtidas nos experimentos quando comparadas com a média obtida pelo experimento controle que utilizou somente sacarose, sem adição dos indutores. 
Os perfis do crescimento celular, $\mathrm{pH}$, atividade surfactante e produtividade em tensoatividade nos testes descritos acima ( $\mathrm{SGO}, \mathrm{SG}, \mathrm{SO}$ e $\mathrm{S}$ ), para a avaliação da ação indutora de óleo de soja e glicerol estão representados na Figura 21.

Figura 21 - Perfil do crescimento celular, pH, atividade biossurfactante e produtividade em tensoatividade nas fermentações utilizando sacarose $(50 \mathrm{~g} / \mathrm{L})$ e glicerol $(3 \% \mathrm{v} / \mathrm{v})(\mathrm{SG})$; sacarose (50 g/L) e óleo de soja (5 \% v/v) (SO); sacarose (50 g/L), óleo de soja (5\% v/v) e glicerol (3 \% v/v) (SOG) e somente sacarose (50 g/L) (S) (fermentação controle) para avaliação da ação indutora de óleo de soja e glicerol para a produção de biossurfactantes por Aureobasidium pullulans LB 83 em fermentação submersa

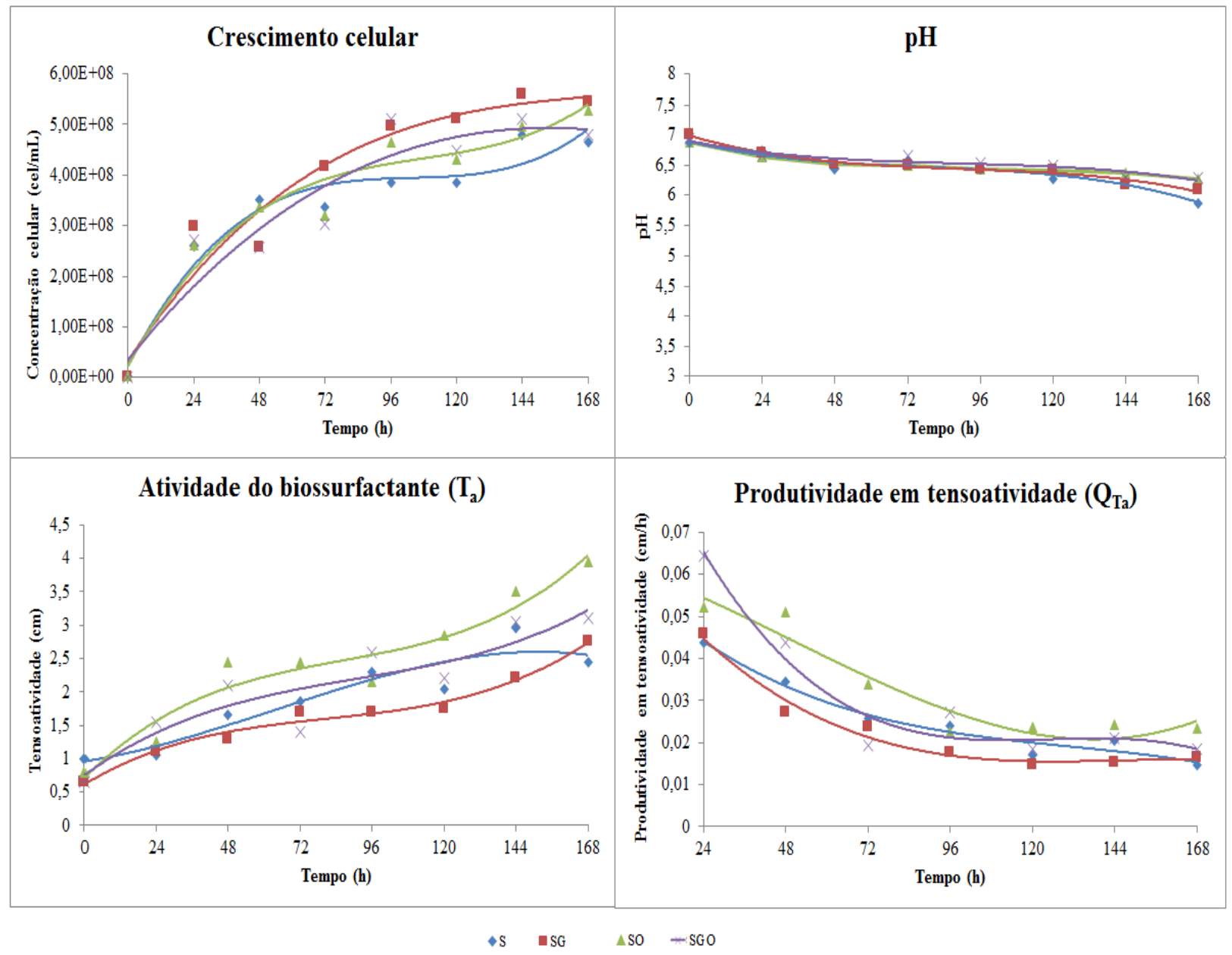

Fonte: Arquivo pessoal.

De acordo com a Figura 21, pôde-se observar que a utilização dos indutores não levou a variações importantes no perfil de $\mathrm{pH}$ e crescimento celular, os quais apresentaram valores muito próximos nos tempos analisados. Os perfis de tensoatividade e produtividade em tensoatividade apresentaram maiores variações entre os valores, nos tempos analisados, 
entretanto, como já discutido anteriormente considerando os valores máximos de tensoatividade a produtividade em tensoatividade (máxima), não houve diferença significativa em relação à condição controle, a um nível de significância de $95 \%$.

Visando avaliar se os indutores glicerol e óleo de soja tinham algum efeito ou interagiam entre si no bioprocesso de produção de biossurfactante, foi realizado o planejamento fatorial completo $2^{2}$ com triplicata no ponto central. Considerou-se tensoatividade (Ta) e produtividade em tensoatividade $\left(\mathrm{Q}_{\mathrm{Ta}}\right)$ como variáveis dependentes, e a adição de glicerol $(0,3$ e 6 g/L) e óleo de soja (0, 5 e $10 \mathrm{~g} / \mathrm{L})$ como variáveis independentes (Tabela 20). Desta forma, neste planejamento utilizou-se concentrações mais altas e mais baixas para os níveis superiores e inferiores, respectivamente, que as utilizadas no teste anterior (Tabela 19), buscando avaliar se alterações nessas concentrações indicariam efeitos significativos.

Tabela 20 - Valores reais e níveis codificados das variáveis independentes concentração de óleo de soja $(\mathrm{g} / \mathrm{L})$ e concentração de glicerol $(\mathrm{g} / \mathrm{L})$ e resultados das variáveis respostas tensoatividade $(\mathrm{cm})$ e produtividade em tensoatividade $(\mathrm{cm} / \mathrm{h})$ para cada ensaio do planejamento estatístico $2^{2}$ completo com três repetições no ponto central, para estudo das condições de fermentação visando produção de biossurfactante por Aureobasidium pullulans LB 83

\begin{tabular}{ccccc}
\hline Experimento & $\begin{array}{c}\text { glicerol } \\
(\mathbf{g} / \mathbf{L})\end{array}$ & $\begin{array}{c}\text { Óleo de } \\
\text { soja }(\mathbf{g} / \mathbf{L})\end{array}$ & $\begin{array}{c}\text { Tensoatividade } \\
\text { máxima }(\mathbf{c m})\end{array}$ & $\begin{array}{c}\text { Produtividade em } \\
\text { tensoatividade }\left(\mathbf{c m}_{\mathbf{h}} \mathbf{- 1}\right)\end{array}$ \\
\hline $0(-1)$ & $0(-1)$ & $\mathbf{2 , 3 5}$ & $\mathbf{0 , 0 3 3}$ \\
\hline 2 & $6(+1)$ & $0(-1)$ & $\mathbf{2 , 6 7}$ & $\mathbf{0 , 0 1 6}$ \\
\hline 3 & $0(-1)$ & $10(+1)$ & $\mathbf{2 , 7 5}$ & $\mathbf{0 , 0 2 9}$ \\
\hline 4 & $6(+1)$ & $10(+1)$ & $\mathbf{4 , 7 5}$ & $\mathbf{0 , 0 3 4}$ \\
\hline 5 & $3(0)$ & $5(0)$ & $\mathbf{5 , 1 0}$ & $\mathbf{0 , 0 3 5}$ \\
\hline 6 & $3(0)$ & $5(0)$ & $\mathbf{4 , 0 0}$ & $\mathbf{0 , 0 3 5}$ \\
\hline 7 & $3(0)$ & $5(0)$ & $\mathbf{5 , 0 0}$ & \\
\hline
\end{tabular}

Fonte: Arquivo pessoal.

Os resultados foram analisados estatisticamente quanto aos valores obtidos das variáveis resposta. Os níveis de significância dessas variáveis e suas interações podem ser observados no gráfico de Pareto na Figura 22. 
Figura 22 - Gráfico de pareto com as variáveis dependentes Tensoatividade máxima e Produtividade em tensoatividade, de acordo com resultados das variáveis independentes (1) concentração de glicerol e (2) concentração de óleo de soja

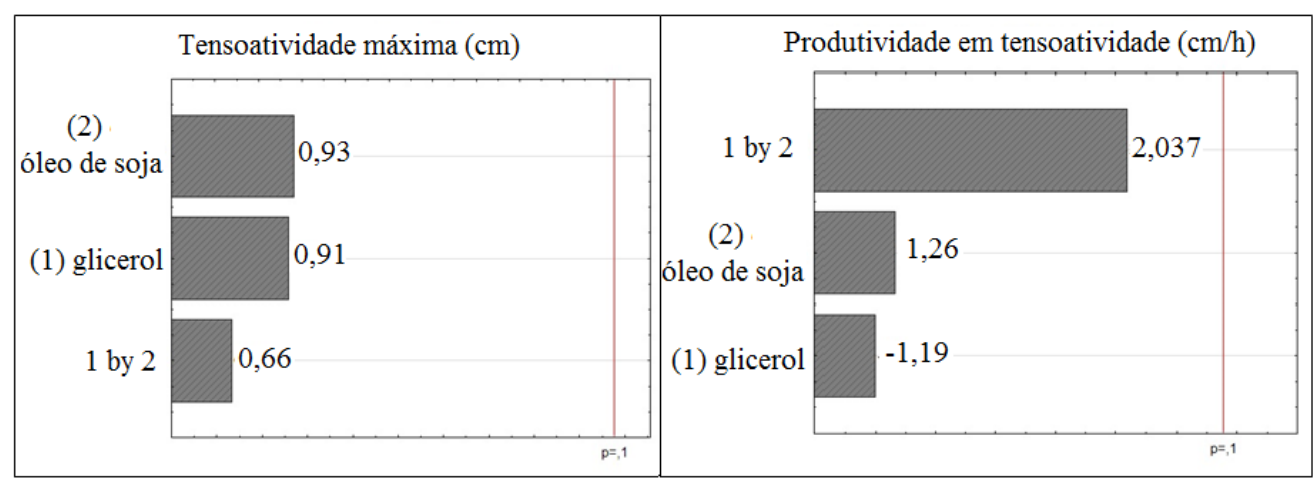

*Estimativa do efeito padronizado (valor absoluto). Fonte: Arquivo pessoal.

De acordo com a análise estatística apresentada, para 90\% de confiança, as variáveis independentes concentração de glicerol, concentração de óleo de soja e a interação entre elas não foram significativas para as variáveis respostas tensoatividade $(\mathrm{cm})$ e produtividade em tensoatividade $(\mathrm{cm} / \mathrm{h})$, no intervalo estudado. Semelhantemente aos resultados dos testes preliminares onde não houve variação na concentração de indutores adicionados (Tabela 19), a adição de óleo de soja e glicerol não apresentou efeito indutor utilizando-se até 6 \% (v/v) para glicerol e até $10 \%(\mathrm{v} / \mathrm{v})$ para o óleo de soja.

Este resultado difere-se de outros trabalhos que demonstraram a ação positiva do uso de indutores e fontes de carbono apolar para a produção de biossurfactantes. Camilios Neto e colaboradores (2011) ao avaliar a influência dos indutores glicerol e óleo de soja na produção de ramnolipídeos por Pseudomonas aeruginosa UFPEDA 614 em fermentação em estado sólido, reportou o efeito positivo da adição dos indutores numa concentração de $6 \%$ (v/v) para cada indutor, sendo a melhor concentração obtida de 45 g/L. Accorsini e colaboradores (2012) também relataram a utilização de glicerol e óleo de soja para a produção de biossurfactantes por leveduras do gênero Candida em fermentação submersa, como alternativa à utilização de carboidratos convencionais. Da mesma forma, Bueno (2014) avaliou a ação indutora de glicerol e óleo de fritura para a produção de biossurfactantes por Bacillus amyloliquefaciens e Bacillus subtillis apontando que a adição de óleo de fritura como indutor influenciou positivamente a produção de biossurfactante e a redução de tensão superficial em ambos micro-organismos. Entretanto, no presente trabalho, para a produção de biossurfactantes pela levedura Aureobasidium pullulans LB 83, não se verificou necessidade da utilização de indutores para a maximização das variáveis resposta estudadas, provavelmente pelo fato do metabolismo de 
produção de biossurfactante dessa levedura não sofrer alteração diante da presença dos compostos estudados.

Neste contexto, para as próximas etapas do trabalho não foram utilizados indutores, sendo que somente a sacarose continuou sendo utilizada como fonte de carbono no processo fermentativo.

5.6.3 Influência da aeração e concentração de sacarose na produção de biossurfactantes por Aureobasidium pullulans LB 83 em fermentação submersa

A produção de biossurfactante por Aureobasidium pullulans é reportado na literatura como um processo que ocorre em condições limitadas de nitrogênio, conduzido em altas concentrações de carbono, com o objetivo de converter o excesso de reagente em bioproduto e menor concentração de biomassa, principalmente metabolitos secundários, como exemplo biossurfactantes (LEATHERS et al., 2015). Além da concentração da fonte de carbono, a taxa de aeração é um fator importante que deve ser ajustado de forma a favorecer maior concentração de bioproduto. Entretanto, esta ainda é uma variável pouco investigada para a levedura $A$. pullulans, uma vez que a maioria dos trabalhos da literatura que relatam a produção de biossurfactantes por este micro-organismo se concentram na caracterização e aplicação da biomolécula, e foram desenvolvidos em frascos Erlenmeyer, dificultando o estabelecimento de valores de aeração (BISCHOFF et al., 2015; KIM et al., 2015; KUROSAWA et al., 1994).

Atualmente, não existem relatos na literatura da produção de biossurfactante por Aureobasidium pullulans em biorreator, como reator de tanque agitado (STR). Neste contexto experimentos em biorreator STR foram conduzidos para o estudo de parâmentros importantes para o processo, como taxa de aeração (vvm) e concentração da fonte de carbono (g/L). Os resultados do planejamento fatorial completo $2^{2}$ com quatro pontos em face centrada e três replicatas no ponto central, de acordo com o planejamento fatorial composto de face centrada (CCFD), que teve como variáveis resposta maior tensoatividade (Ta) e produtividade em tensoatividade $\left(\mathrm{Q}_{\mathrm{Ta}}\right)$ estão apresentados na Tabela 22.

Inicialmente, somente os experimentos de 1 a 7 apresentados na Tabela 22, correspondente ao planejamento fatorial completo $2^{2}$, foram realizados e analisados para entender o efeito das variáveis na produção de biossurfactantes. No intervalo estudado para as variáveis independents, um $\Delta$ Ta de 7,5 cm foi obtido, com o menor valor de $0,55 \mathrm{~cm}$ no teste de espalhamento da gota, encontrado no experimento 1 (aeração de $0,1 \mathrm{~min}^{-1}$ e concentração de 
sacarose de $20 \mathrm{~g} / \mathrm{L}$ ) e o maior valor de $8,05 \mathrm{~cm}$, conservado no experimento 4 (aeração de 1,1 $\min ^{-1}$ e concentração de sacarose de $80 \mathrm{~g} / \mathrm{L}$ ).

A significância estatística dos efeitos das variáveis estudadas para tensoatividade e produtividade em tensoatividade do biossurfactante foram avaliadas utilizando o gráfico de Pareto (Figura 23).

Tabela 21 - Planejamento fatorial completo $2^{2}$ com quatro pontos em face centrada e três replicatas no ponto central, de acordo com o planejamento fatorial composto de face centrada (CCFD), com valores das variáveis independentes taxa de aeração (vvm) e concentração de sacarose (g/L), para a produção de biossurfactante por Aureobasidium pullulans LB 83 em reator de tanque agitado, com máxima tensoatividade e produtividade em tensoatividade como variáveis resposta

\begin{tabular}{ccccc}
\hline Experimento & $\begin{array}{c}\text { Taxa de } \\
\text { aeração } \\
\left(\text { min }^{-1}\right)\end{array}$ & $\begin{array}{c}\text { Concentração } \\
\text { de sacarose } \\
\left(\text { g.L }^{-1}\right)\end{array}$ & $\begin{array}{c}\text { Máxima } \\
\text { tensoatividade } \\
(\mathbf{c m})\end{array}$ & $\begin{array}{c}\text { Produtividade em } \\
\text { tensoatividade } \\
\left(\mathbf{c m}^{-1}\right)\end{array}$ \\
\hline 1 & $0,1(-1)$ & $20(-1)$ & $\mathbf{0 , 5 5}$ & $\mathbf{0 , 0 0 7 6}$ \\
\hline 2 & $1,1(+1)$ & $20(-1)$ & $\mathbf{1 , 8 5}$ & $\mathbf{0 , 0 3 8 5}$ \\
\hline 3 & $0,1(-1)$ & $80(+1)$ & $\mathbf{0 , 9 0}$ & $\mathbf{0 , 0 0 6 2}$ \\
\hline 4 & $1,1(+1)$ & $80(+1)$ & $\mathbf{8 , 0 5}$ & $\mathbf{0 , 0 8 3 8}$ \\
\hline 5 & $0,6(0)$ & $50(0)$ & $\mathbf{6 , 0 5}$ & $\mathbf{0 , 0 6 3 0}$ \\
\hline 6 & $0,6(0)$ & $50(0)$ & $\mathbf{5 , 4 0}$ & $\mathbf{0 , 0 5 6 2}$ \\
\hline 7 & $0,6(0)$ & $50(0)$ & $\mathbf{6 , 9 5}$ & $\mathbf{0 , 0 0 4 1}$ \\
\hline 8 & $0,1(-1)$ & $50(0)$ & $\mathbf{0 , 5 0}$ & $\mathbf{0 , 0 8 3 3}$ \\
\hline 9 & $1,1(+1)$ & $50(0)$ & $\mathbf{6 , 0}$ & $\mathbf{0 , 0 1 6 1}$ \\
\hline 10 & $0,6(0)$ & $20(-1)$ & $\mathbf{0 , 7 7}$ & $\mathbf{0 , 0 5 4 1}$ \\
\hline 11 & $0,6(0)$ & $80(+1)$ & $\mathbf{5 , 2 0}$ & \\
\hline
\end{tabular}

*Valores codificados das variáveis estudadas encontram-se entre parênteses. Fonte: Arquivo pessoal. 
Figura 23 - Gráfico de Pareto para tensoatividade máxima $(\mathrm{cm})$ e produtividade em tensoatividade $(\mathrm{cm} / \mathrm{h})$ de biossurfactante, de acordo com a análise estatística do planejamento factorial completo $2^{2}$ realizado para avaliar a influência da (1) taxa de aeração (vvm) $\left(\mathrm{min}^{-1}\right)$ e (2) concentração de sacarose (g/L) no processo de produção de biossurfactante por Aureobasidium pullulans LB 83 em reator de tanque agitado

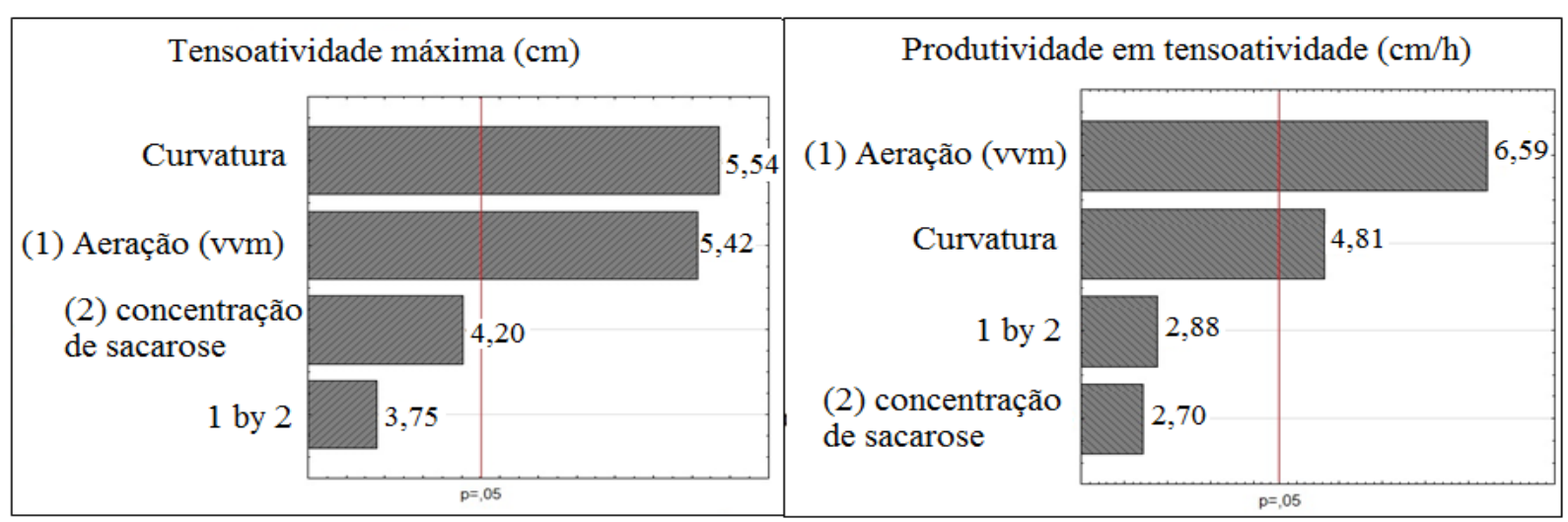

*Estimativa do efeito padronizado (valor absoluto). Fonte: Arquivo pessoal.

O efeito principal da variável aeração e curvatura foram significantes a um nível de $95 \%$ de confiança para as duas variáveis resposta Ta e $\mathrm{Q}_{\mathrm{Ta}}$. Entretanto, a concentração de sacarose e os efeitos das interações não foram significativos a um nível de $95 \%$ de confiança, no intervalo estudado para as variáveis. O teste de curvatura apresentou significância a um nível de $95 \%$ de confiança, o que indica que um modelo de segunda ordem pode explicar melhor os resultados experimentais obtidos. Assim, experimentos adicionais foram realizados para obter resultados para as condições de otimização, de acordo com um delineamento composto de face centrada (CCFD) (experimentos adicionais 8 a 11 apresentados na Tabela 21). A análise de variância relacionada ao delineamento experimental apresentado na Tabela 21 é apresentado na Tabela 22 para os modelos de segunda ordem compostos para descrever as variáveis em função da aeração e concentração de sacarose. 
Tabela 22 - Análise de variância (ANOVA) para os modelos ajustados para a variável resposta tensoatividade máxima (Ta) e produtividade em tensoatividade $\left(\mathrm{Q}_{\mathrm{Ta}}\right)$ em função das variáveis estudadas taxa de aeração (vvm) e concentração de sacarose $(\mathrm{g} / \mathrm{L})$ no processo de produção de biossurfactantes por Aureobasidium pullulans LB 83 em reator de tanque agitado.

\begin{tabular}{|c|c|c|c|c|c|}
\hline \multicolumn{6}{|c|}{ Ta } \\
\hline Variável & SS & df & MS & $\mathbf{F}$ & $\bar{p}$ \\
\hline $\operatorname{Ar}(L)$ & 32,434 & 1 & 32,434 & 53,536 & $0,018 *$ \\
\hline $\operatorname{Ar}(\mathbf{Q})$ & 5,278 & 1 & 5,278 & 8,712 & $0,098 * *$ \\
\hline SC (L) & 20,093 & 1 & 20,093 & 33,166 & $0,029 *$ \\
\hline $\mathrm{SC}(\mathrm{Q})$ & 7,394 & 1 & 7,394 & 12,205 & $0,073 * *$ \\
\hline$\overline{\operatorname{Ar}} \times \mathrm{SC}$ & 8,556 & 1 & 8,556 & 14,122 & $0,064 * *$ \\
\hline Falta de ajuste & 5,714 & 3 & 1,904 & 3,144 & 0,251 \\
\hline Erro puro & 1,212 & 2 & \multicolumn{3}{|c|}{0,606} \\
\hline Total SS & 85,237 & 10 & & & \\
\hline \multicolumn{6}{|l|}{$\mathbf{R}^{2}=0,91875$} \\
\hline \multicolumn{6}{|c|}{$\mathbf{Q}_{\text {Ta }}$} \\
\hline Variável & SS & df & MS & $\mathbf{F}$ & $\mathbf{p}$ \\
\hline $\operatorname{Ar}(L)$ & 0,0059 & 1 & 0,0059 & 89,890 & $0,011^{*}$ \\
\hline $\mathrm{SC}(\mathrm{L})$ & 0,0011 & 1 & 0,0011 & 17,114 & $0,054 * *$ \\
\hline SC (Q) & 0,0012 & 1 & 0,0012 & 19,114 & $0,048 *$ \\
\hline$\overline{\operatorname{Ar}} \times \mathrm{SC}$ & 0,0005 & 1 & 0,0005 & 8,346 & 0,102 \\
\hline Falta de ajuste & 0,0008 & 4 & 0,0002 & 2,990 & 0,266 \\
\hline Erro puro & 0,0001 & 2 & \multicolumn{3}{|c|}{0,00006} \\
\hline Total SS & 0,0097 & 10 & & & \\
\hline
\end{tabular}

* Fatores significantes a um nível de 95\% de confiança; ** Fatores significantes a um nível de $90 \%$ de confiança. Fonte: Arquivo pessoal.

Os modelos de segunda ordem estão apresentados nas equações 6 e 7 para as variáveis resposta Ta e $\mathrm{Q}_{\mathrm{Ta}}$.

$$
\begin{gathered}
T a=-4.18177+6.70342 \times(A r)+0.19232 \times(S C)-5.77368 \times(A r)^{2} \\
-0.00190 \times(S C)^{2}+0.09750 \times(A r) \times(S C)
\end{gathered}
$$

onde: Ta é Tensoatividade máxima $(\mathrm{cm}) ; A r$ é taxa de aeração $\left(\mathrm{min}^{-1}\right)$; e $C S$ é concentração de sacarose $(\mathrm{g} / \mathrm{L})$

$$
\begin{aligned}
Q_{T a}=- & 0.040595+0.0023650 \times(A r)+0.002365 \times(S C)-0.000024 \times(S C)^{2} \\
& +0.000778 \times(A r) \times(S C)
\end{aligned}
$$

onde: $Q_{T a}$ é produtividade em tensoatividade $(\mathrm{cm} / \mathrm{h}) ; A r$ é taxa de aeração $\left(\mathrm{min}^{-1}\right)$; e $S C$ é concentração de sacarose $(\mathrm{g} / \mathrm{L})$ 
Os modelos não apresentaram falta de ajuste, e apresentaram valores de $\mathrm{R}^{2}$ de $0,92 \mathrm{e}$ 0,91, respectivamente. Então, estes foram considerados adequados para descrever as variáveis respostas em função das variáveis independentes estudadas.

As Figuras 24 e 25 apresentam os gráficos de superfície de resposta e contorno para ambas as variáveis para o melhor entendimento do perfil da taxa de aeração e concentração de sacarose de acordo as respostas Ta e $\mathrm{Q}_{\mathrm{Ta}}$.

De acordo com as Figuras 24 e 25, por meio da análise da superfície de resposta e contorno, maiores valores de $\mathrm{Ta}$ e $\mathrm{Q}_{\mathrm{Ta}}$ foram atingidos quando a taxa de aeração e a concentração de sacarose foram aumentados. Como apresentado na Tabela 22, os maiores valores experimentais de Ta e $\mathrm{Q}_{\mathrm{Ta}}$ foram encontrados no experimento 4, com as duas variáveis independentes (taxa de aeração e concentração de sacarose) no maior nível.

Apesar da análise estatística indicar que o aumento dos valores das duas variáveis independentes pode aumentar os valores Ta e $\mathrm{Q}_{\mathrm{Ta}}$, a utilização de maiores valores de aeração que o intervalo avaliado poderiam resultar em problemas operacionais. Durante os experimentos que utilizaram maiores valores de aeração (Ex. 2, 4 e 9), uma grande produção de espuma foi observada no reator, indicando dificuldades operacionais para o uso de valores maiores que $1,1 \mathrm{~min}^{-1}$ no sistema proposto (Figura 26).

Figura 24 - Superfície de resposta (A) e linhas de contorno correspondente (B) para as respostas Tensoatividade máxima (Ta), considerando taxa de aeração e concentração de sacarose como variáveis independentes no processo de produção de biossurfactantes por Aureobasidium pullulans LB 83 em reator de tanque agitado.

(A)

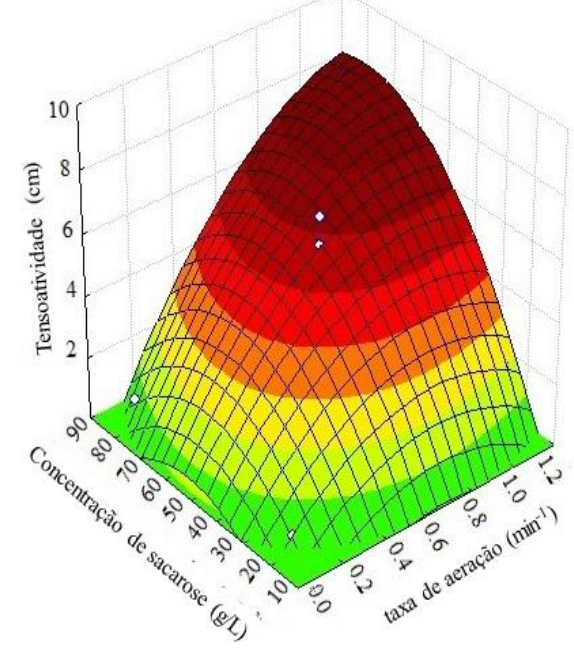

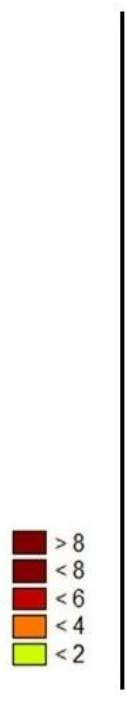

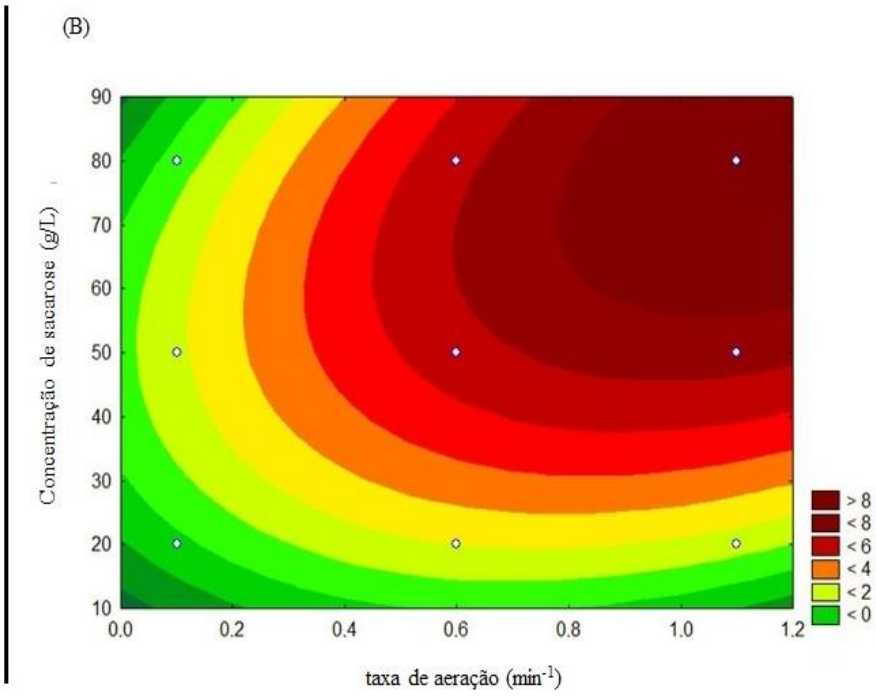

Fonte: Arquivo pessoal. 
Figura 25 - Superfície de resposta (A) e linhas de contorno correspondente (B) para as respostas Produtividade em tensoatividade $\left(\mathrm{Q}_{\mathrm{Ta}}\right)$, considerando taxa de aeração e concentração de sacarose como variáveis independentes no processo de produção de biossurfactantes por Aureobasidium pullulans LB 83 em reator de tanque agitado

(A)

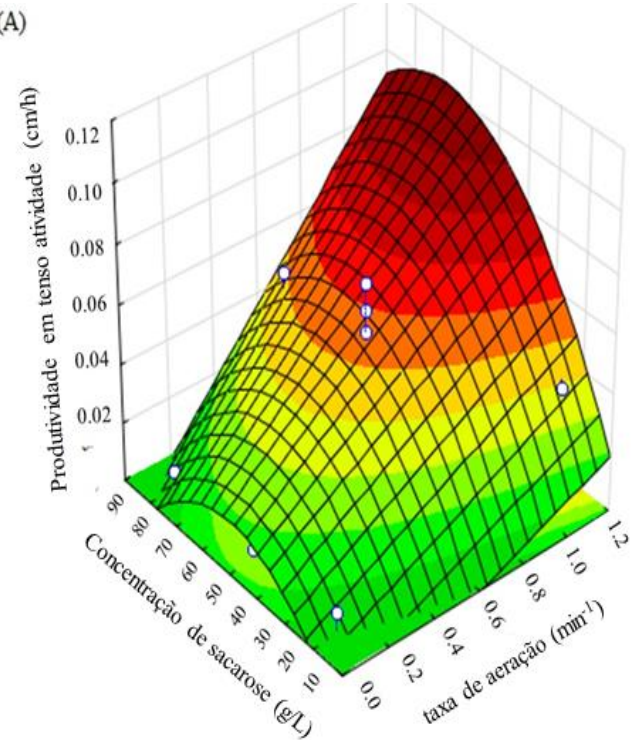

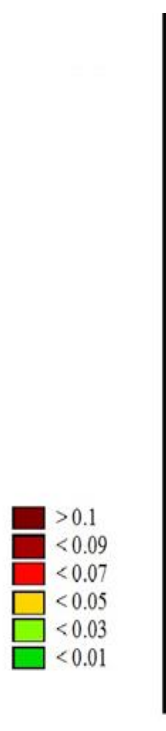

(B)

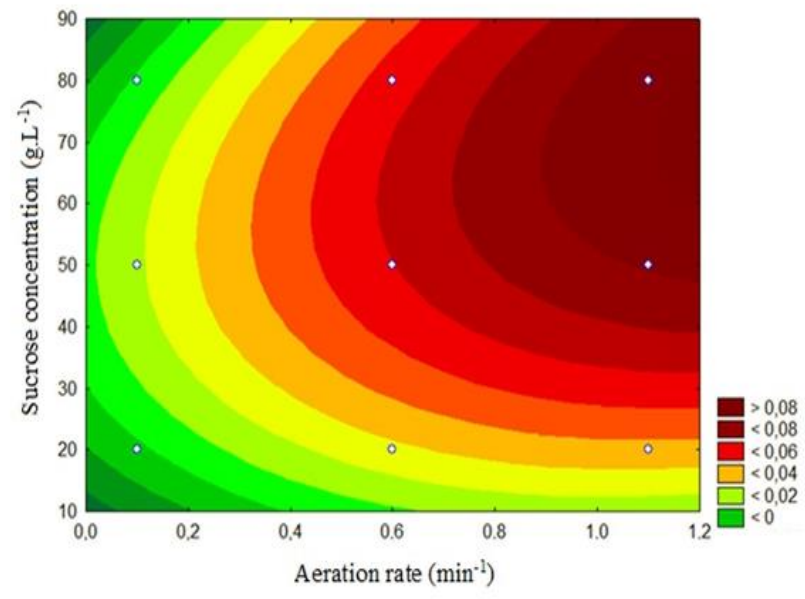

Fonte: Arquivo pessoal.

Figura 26 - Formação de espuma na fermentação submersa em biorreator (BIOSTAT BPlus de 5 L, Sartorius AG, Alemanha). Concentração de sacarose 80g/L, taxa de aeração $1,1 \mathrm{~min}^{-1}$ (A: $120 \mathrm{~h}$ de cultivo; B: 168 h de cultivo).

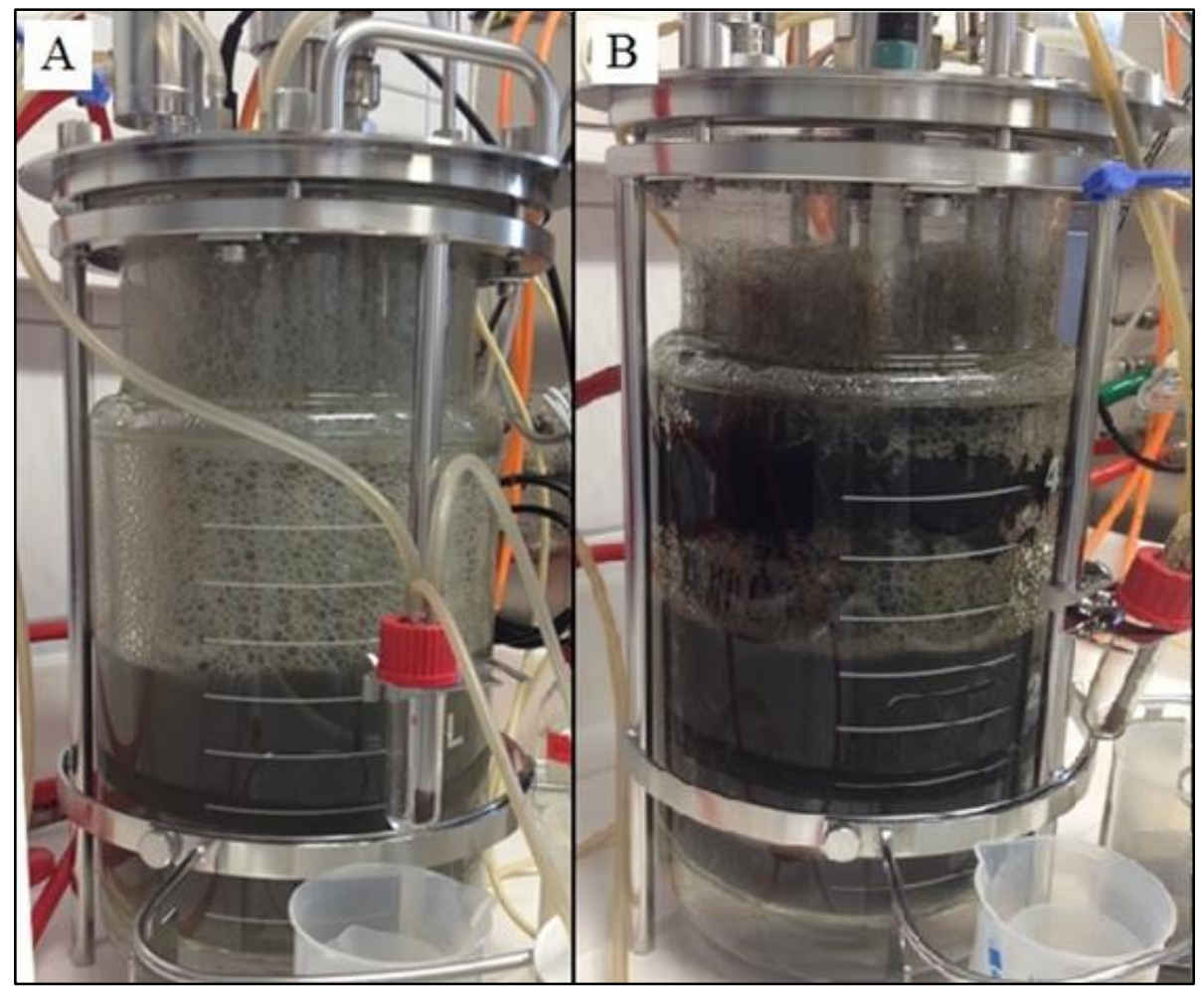

Fonte: Arquivo pessoal. 
A produção de espuma tem sido descrita como um problema na produção de biossurfactantes em larga escala, levando à perda de biomassa, nutriente e bioproduto (CAMILIOS NETO, 2010). Essa espuma pode levar a uma diminuição nos parâmetros de produção e o uso de antiespumantes pode inibir a produção de biossurfactantes (LEE e KIM, 2004), além de interferir na resposta das metodologias analíticas para análise de tensoatividade e emulsificação.

No presente trabalho, como verificado nas Figuras 24 e 25, uma taxa de aeração de 1,1 $\min ^{-1}$ foi suficiente para atingir o ponto ótimo das variáveis respostas Ta e $\mathrm{Q}_{\mathrm{Ta}}$. Com relação à concentração de açúcar, valores maiores que o intervalo estudado poderiam resultar em maior viscosidade do meio no fim do processo devido à grande produção de pululana (HYUNG-PHIL et al., 2006), desta forma, dificultando a operação no reator de tanque agitado.

O rápido consumo de sacarose observado em todas as condições experimentais (Figura 27) se deve à ação da invertase extracelular, a qual hidrolisa sacarose em glicose e frutose. Além disso, parte da sacarose também é transportada para o meio intracelular via proteína de membrana sacarose $\mathrm{H}^{+}$do tipo simporte, e então hidrolisado no ambiente intracelular (WEI et al., 2017). Consequentemente, um aumento de glicose e frutose foi observado até $48 \mathrm{~h}$ em todas as condições experimentais (Figura 27). Nos experimentos com maior aeração, 1,1 min ${ }^{-1}$ (experimentos 2, 4 e 9), e no ponto central, $0,6 \mathrm{~min}^{-1}$ (experimentos 5, 6, 7, 10 e 11), a sacarose foi consumida até $24 \mathrm{~h}$. Nos experimentos com menor aeração, $0,1 \mathrm{~min}^{-1}$ (Experimentos 1, $3 \mathrm{e}$ 8) a sacarose foi metabolizada mais lentamente, levando até $48 \mathrm{~h}$ de fermentação. Esse fato está relacionado com o maior metabolismo oxidativo e crescimento celular que ocorre em condições de maior aeração (OURA, 1974). Gaur e colaboradores (2010) reportaram que em condições anaeróbicas, a levedura Aureobasidium pullulans não apresentou crescimento celular nem produção de pululana, o que indicou uma redução do seu metabolismo.

Ainda de acordo com a Figura 27, observou-se a propensão do micro-organismo A. pullulans LB 83 em usar glicose preferivelmente à frutose. Foi observado que a frutose não foi totalmente consumida até 168 h quando a concentração inicial de açúcar era igual ou maior que $50 \mathrm{~g} / \mathrm{L}$ (experimentos 3, 4, 8, 9 e 11). Esse comportamento já havia sido reportado por Sheng e colaboradores (2016), quando esses autores utilizaram sacarose para a produção de pululana por A. pullulans, e verificaram que quando glicose e frutose estavam simultaneamente presentes no meio (após clivagem da sacarose), a concentração de glicose apresentou um decrecimo mais rápido que a concentração de frutose. Portanto, pôde-se observar que, 
comparado à frutose, a glicose é preferencialmente utilizada pela levedura Aureobasidium pullulans.

A literatura reporta a importância da composição do meio de cultura para a produção de biossurfactantes por Aureobasidium pullulans. Por exemplo, Leathers e colaboradores (2015) avaliaram diferentes composições de meio para a produção de biossurfactante (liamocina) por diversas estirpes de $A$. pullulans, e verificaram que o meio base com sacarose apresentou melhores resultados. O meio de cultura utilizado no presente trabanho contém a mesma composição e concentração de sacarose que o meio utilizado por Manitchotpisit e colaboradores (2011). Entretanto, o aumento da concentração de sacarose pode levar a um aumento na produção de biossurfactantes, pois foi descrito por Casas e Ochoa (1999) que uma alta proporção carbono/nitrogênio $(\mathrm{C} / \mathrm{N})$ é de grande importância na biossíntese de biossurfactantes por leveduras. Em seu trabalho, os autores avaliaram a produção de soforolipídeos por Candida bombicola, e observaram que concentrações de nitrogênio maiores (consequentemente menor taxa $\mathrm{C} / \mathrm{N}$ ) levaram a uma menor produção de biossurfactantes e direcionou o metabolismo para a produção de biomassa.

$\mathrm{O}$ aumento da relação $\mathrm{C} / \mathrm{N}$ neste estudo foi atingida pelo aumento da concentração de sacarose, uma vez que as fontes de nitrogênio já eram limitadas na composição do meio utilizado no presente trabalho.

Considerando o crescimento celular, a vazão de aeração é considerada como um importante fator para o aumento da concentração celular. Em experimentos com vazão de aeração no menor nível, 0,1 min $^{-1}$ (experimentos 1, 3 e 8), menores concentrações celulares foram atingidas (menos que $4 \mathrm{~g} / \mathrm{L}$ ). Também foi observado que concentração inicial de sacarose no maior nível (80 g/L) não foi capaz de inibir o crescimento celular do fungo leveduriforme Aureobasidium pullulans LB 83, como demonstrado na Figura 27. Foi observado que, nos experimentos com aeração no menor nível $\left(0,1 \mathrm{~min}^{-1}\right)$, todo oxigênio fornecido foi totamente consumido após $24 \mathrm{~h}$ de fermentação, uma vez que o $\mathrm{pO}_{2}(\%)$ se manteve $0 \%$ até o fim do processo. Esse fato pode indicar que esse nível de aeração foi insuficiente para o crescimento e metabolismo da levedura, e por isso levou ao menor crescimento celular e produção de biossurfactante. Nas outras condições de aeração $\left(0,6\right.$ e 1,1 $\left.\mathrm{min}^{-1}\right)$, o $\mathrm{pO}_{2}$ também atingiu $0 \%$ em 24 h (tempo de maior crescimento celular e metabolismo da levedura na fase log), mas após esse tempo os valores de $\mathrm{pO}_{2}$, aumentaram novamente, indicando que a aeração fornecida foi suficiente para atender às necessidades das células de levedura. 
Figura 27 - Concentração de açúcares (sacarose, glicose e fructose) durante a fermentação para produção de biossurfactantes por Aureobasidium pullulans LB 83 em diferentes condições de aeração e concentração inicial de sacarose.

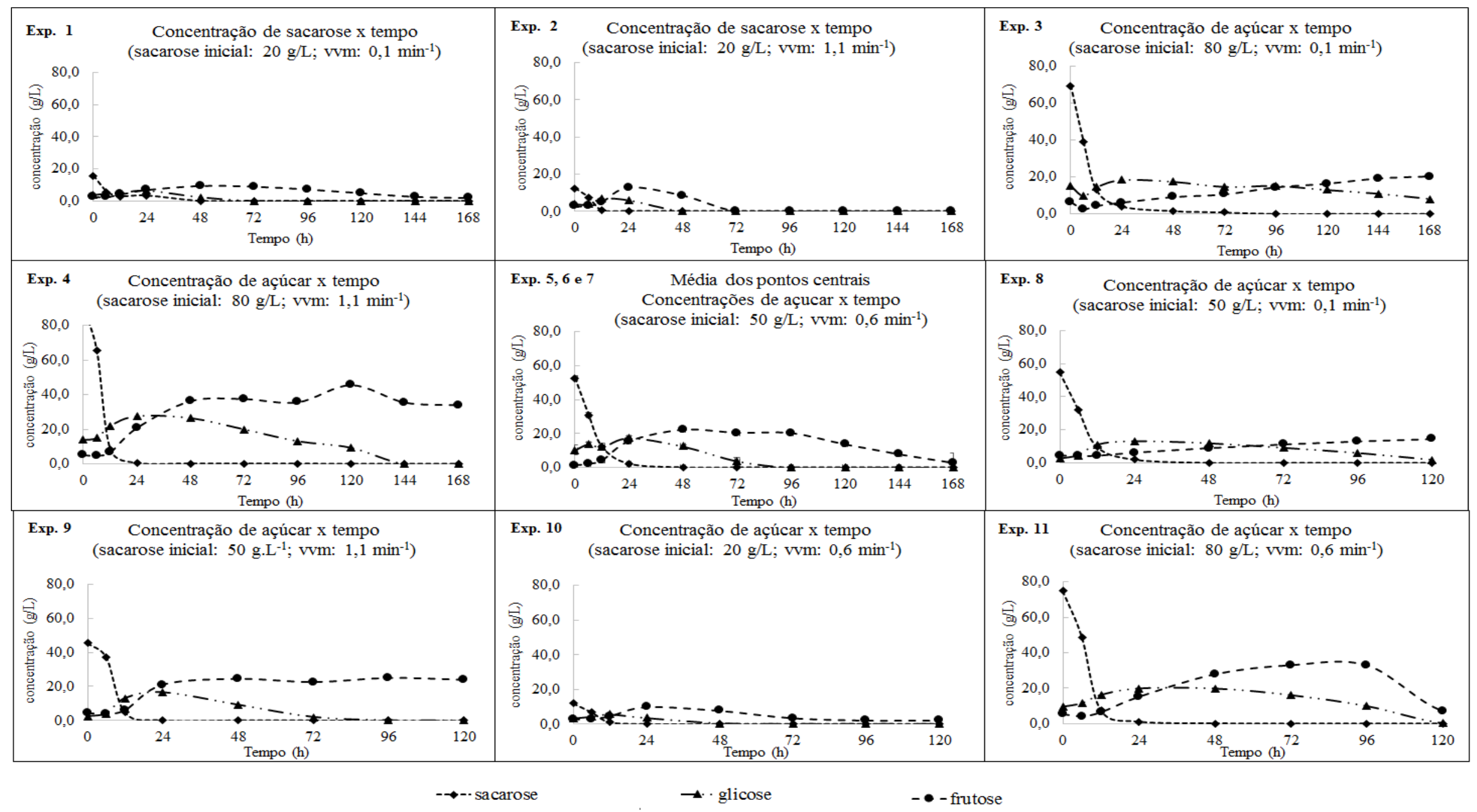

Fonte: Arquivo pessoal. 
De acordo com a Figura 28, uma associação entre o crescimento celular e a tensoatividade foi verificada (LEATHERS et al., 2015). Maiores valores de atividade biossurfactante (tensoatividade) foram observados nos experimentos em que maiores concentrações celulares foram obtidas, como nos experimentos 4, 5, 6, 7, 9 e 11. Somente no experimento 10 essa associação não foi observada. Normalmente, uma correlação entre a produção de biossurfactante e o crescimento cellular é reportado para A. pullulans (LEATHERS et al., 2015).

Considerando a tolerância da levedura Aureobasidium pullulans a altas concentrações iniciais de sacarose, Sheng e colaboradores (2016) observaram que este micro-organismo tem a habilidade de secretar quantidades substanciais de $\beta$-frutofuranosidase para diminuir a pressão osmótica do fluido extracelular, e assim A. pullulans foi capaz de crescer mais rapidamente durante os estágios iniciais da fermentação. Os autores relataram que a inibição do crescimento celular só foi observada em concentrações iniciais de sacarose acima de $120 \mathrm{~g} / \mathrm{L}$. Este mecanismo justifica a resistência desse micro-organismo à pressão osmótica e explica porque as altas concentrações de sacarose não afetaram o crescimento celular no presente trabalho.

Um fator de grande importância que influencia no crescimento celular é a aeração. Uma maior aeração levou a um maior crescimento celular devido ao metabolismo oxidativo (SILVA; MUSSATO; ROBERTO, 2010). O fato de existir uma correlação entre o crescimento celular e a produção de biossurfactante por A. pullulans corrobora com os resultados encontrados na Figura 28, explicando porque o uso de maior taxa de aeração proporcionou uma maior produção de biossurfactante. Entretanto, o papel do oxigênio no mecanismo da produção de biossurfactante por Aureobasidium pullulans ainda não é completamente compreendido. Não existem relatos na literatura que reportam a influência da aeração no processo de produção de biossurfactantes por esta levedura.

O estudo de parâmetros do processo, como a aeração, e o uso de um reator STR que possui geometria definida, são importantes para a viabilidade de ampliação desse sistema. Uma vez que pequenas variações no fornecimento e distribuição de oxigênio podem influenciar diretamente certas variáveis nos biorreatores, outros parâmetros são importantes para além da similaridade geométrica. Desta forma, o valor do coeficiente de transferência de oxigênio volumétrico $\left(\mathrm{K}_{\mathrm{L}} \mathrm{a}\right)$ foi medido e, para a condição de maior produção de biossurfactante, o valor obtido foi de $26,28 \mathrm{~h}^{-1}$. O conhecimento do valor de $\mathrm{K}_{\mathrm{L}}$ a pode ser útil em experiências futuras como critério de aumento de escala. Este é o valor de $\mathrm{K}_{\mathrm{L} a}$ inicial do processo (estabelecido antes da inoculação do microrganismo), durante o processo fermentativo o coeficiente de transferência de oxigênio se altera com as modificações na composição e reologia do meio. 
Figura 28 - Tensoatividade e biomassa durante a fermentação para produção de biossurfactantes por Aureobasidium pullulans LB 83 em diferentes condições de aeração e concentração inicial de sacarose.

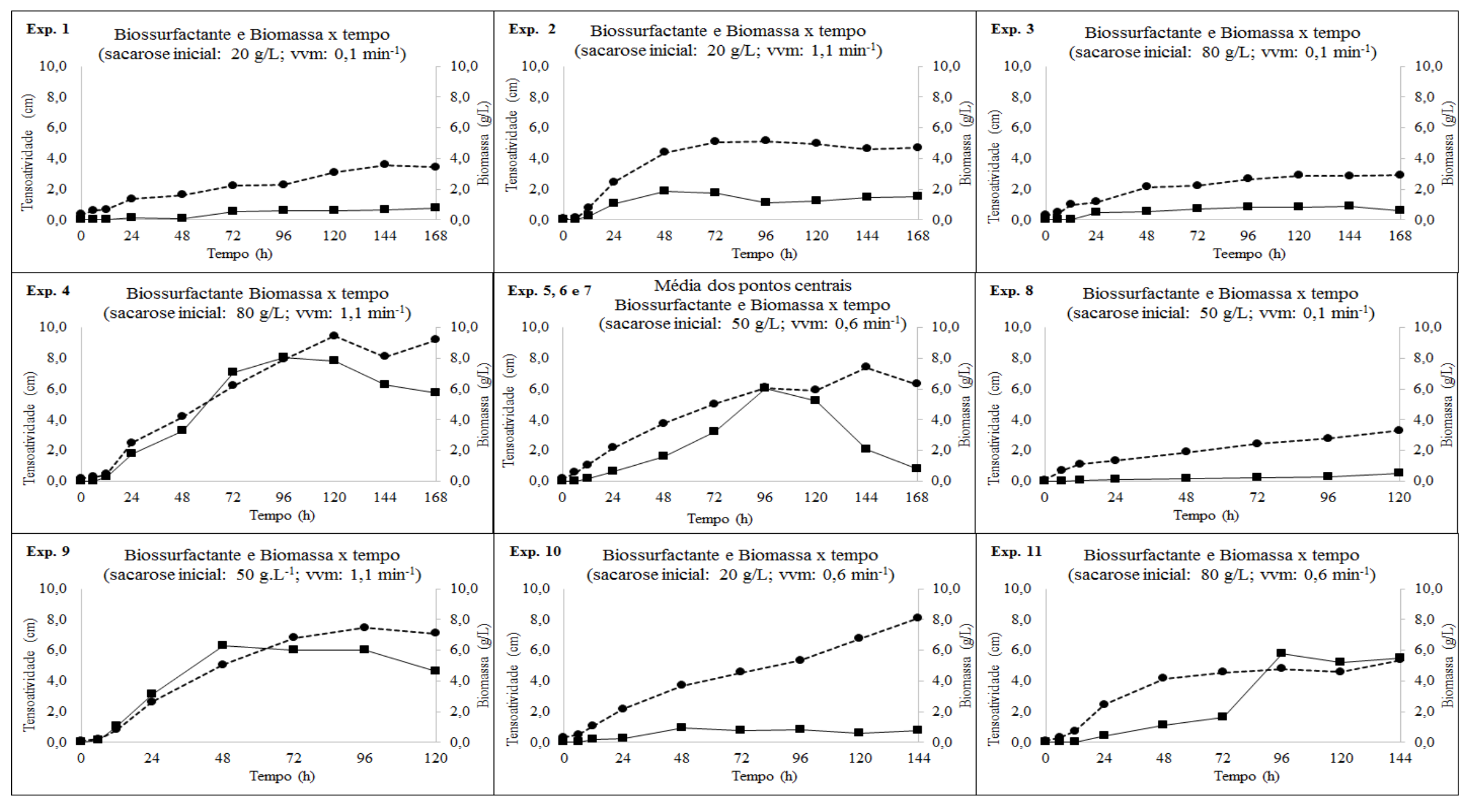

$\rightarrow-$ Tensoatividade $\rightarrow$ - Biomassa

Fonte: Arquivo pessoal. 
Quanto à atividade do biossurfactante, representada pela tensoatividade, os valores mais altos foram obtidos em diferentes tempos de acordo com as diferentes condições experimentais (experimentos 2 e $10 \mathrm{em} 48 \mathrm{~h}$; experimentos 1 e $9 \mathrm{em} \mathrm{72h}$; experimento 4, pontos centrais (5, 6 e 7), e 11 em 96 h; experimento 8 em 120 h, experimento 3 em 144 h). Assim, as diferenças entre os tempos de máxima tensoatividade foram importantes, pois influenciam diretamente no cálculo da produtividade $\left(\mathrm{Q}_{\mathrm{T}}\right)$.

Comparando com outros trabalhos descritos na literatura, a tensoatividade máxima (Ta) e a produtividade em tensoatividade encontrados no presente trabalho $(8,05 \mathrm{~cm}$ e $0.0838 \mathrm{~cm} / \mathrm{h}$, respectivamente) foram maiores que alguns resultados reportados utilizando Bacillus subtilis, uma bactéria conhecida como produtora de biossurfactante. Por exemplo, Al-Bahry et al. (2013) relataram em seu trabalho resultados inferiores a $1,2 \mathrm{~cm}$ no teste do espalhamento da gota para tensoatividade, o que correspondeu a uma produtividade de $0,0167 \mathrm{~cm} / \mathrm{h}$ utilizando diferentes estirpes de Bacillus. Diab e Din (2013) reportaram máximos valores de 8,1 e 5,9 cm de diâmetro quando investigaram duas estirpes diferentes de Bacillus (SH 26 e SH 20) após 48 h de cultivo, o que correspondeu a valores de produtividade em tensoatividade de 0,1687 e $0,1144 \mathrm{~cm} / \mathrm{h}$, respectivamente. Os mesmos autores também testaram uma estirpe de Pseudomonas aeruginosa, outra bactéria tradicional pela produção de biossurfactantes, a qual obteve valores de 4,5 cm para tensoatividade após $48 \mathrm{~h}$, equivalente à uma produtividade em tensoatividade de $0,093 \mathrm{~cm} / \mathrm{h}$. Também, Thavasi e colaboradores (2011) reportaram um máximo de $3,5 \mathrm{~cm}$ no teste de tensoatividade quando testou 105 bactérias marinhas, incluindo estirpes de Bacillus subtilis, Pseudomodas aeruginosa, Corynebacterium kutscheri, Klebsiella ozaenae e outras.

Em trabalho utilizando o fungo filamentoso Cunninghamella echinulata, Silva e colaboradores (2014a) reportaram um diâmetro de $6,89 \mathrm{~cm}$ quando $1 \%$ do biossurfactante purificado foi utilizado no teste de espalhamento da gota. Os mesmos autores também relatram valores de $4,5 \mathrm{~cm}$ utilizando detergente comercial $1 \%$ e $6,70 \mathrm{~cm}$ quando utilizaram Triton $\mathrm{X}$ $1001 \%$, um surfactante químico de referência.

Assim, pôde-se observar que no presente trabalho foram obtidos valores próximos ou maiores que os relatados para bactérias consideradas boas produtoras de biossurfactante e até mesmo em comparação a soluções utilizando surfactantes químicos. Porém é importante destacar que o valor de tensoatividade não depende somente da concentração do biossurfactante, mas também do peso molecular e da composição das partes hidrofílicas e lipofílicas da sua molécula (SATPUTE et al., 2010).

Foi observado que as diferentes condições experimentais utilizadas no planejamento levaram a diferenças também no aspecto final do meio fermentado (Figura 29). Dependendo 
das condições de aeração e concentração inicial de sacarose, uma coloração mais escura ou maior viscosidade do meio foram observadas. A coloração escura é explicada pela formação de clamidosporos nos estágios finais do ciclo de vida do A. pullulans, devido à produção de melanina (CHI et al., 2009; LEATHERS et al., 2015). Como a disponibilidade de fonte de carbono e a aeração interferem na duração do ciclo de vida do micro-organismo, a variação das condições utilizadas no planejamento levaram à essas diferenças na coloração do meio ao final da fermentação, variando de rosado (experimentos 3 e 8), verde oliva (experimentos 1, 2, 10 e 11) até o negro (experimentos 4, 5, 6, 7 e 9) (Figura 29).

Figura 29 - Aspecto final dos meios de cultivo após 168 h de fermentação em diferentes condições de aeração e concentração inicial de sacarose: diferença de coloração e viscosidade

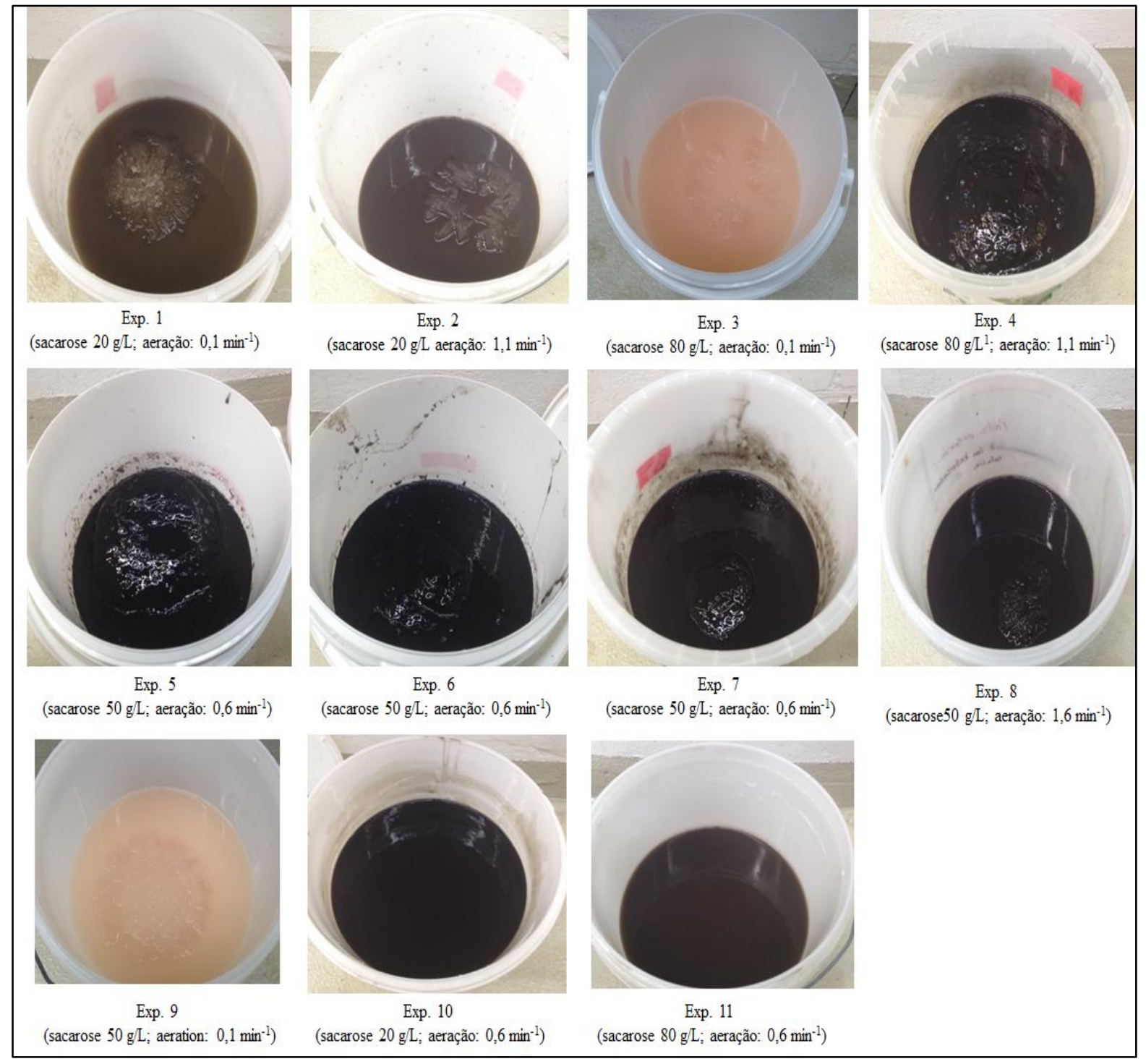

Fonte: Arquivo pessoal. 
As diferenças nas viscosidades dos meios de cultura ao final de cada fermentação podem ser explicadas pela produção de pululana, um homopolissacarídeo solúvel em água produzido extracelularmente pelo microrganismo. A produção de pululana também é favorecida em condições aeróbias e com limitação de nitrogênio (AUDET et al., 1996), por isso o experimento com maior aeração e maior concentração de açúcar (experimento 4) foi aquele que apresentou maior viscosidade aparente (observado visualmente) em relação aos experimentos com menor concentração de sacarose e menor aeração.

\subsection{Avaliação da correlação entre a atividade tensoativa no teste de espalhamento} da gota e concentração do biossurfactante

A correlação entre a tensoatividade obtida no teste de espalhamento da gota $(\mathrm{cm})$ e a concentração $(\mathrm{g} / \mathrm{L})$ do biossurfactante produzido por Aureobasidium pullulans LB 83 no presente trabalho está apresentado na Figura 30.

Figura 30 - Relação entre a tensoatividade (diâmetro do halo obtido pela técnica de espalhamento da gota) $(\mathrm{cm})$ e a concentração de biossurfactante $(\mathrm{g} / \mathrm{L})$. A linha representa a regressão linear.

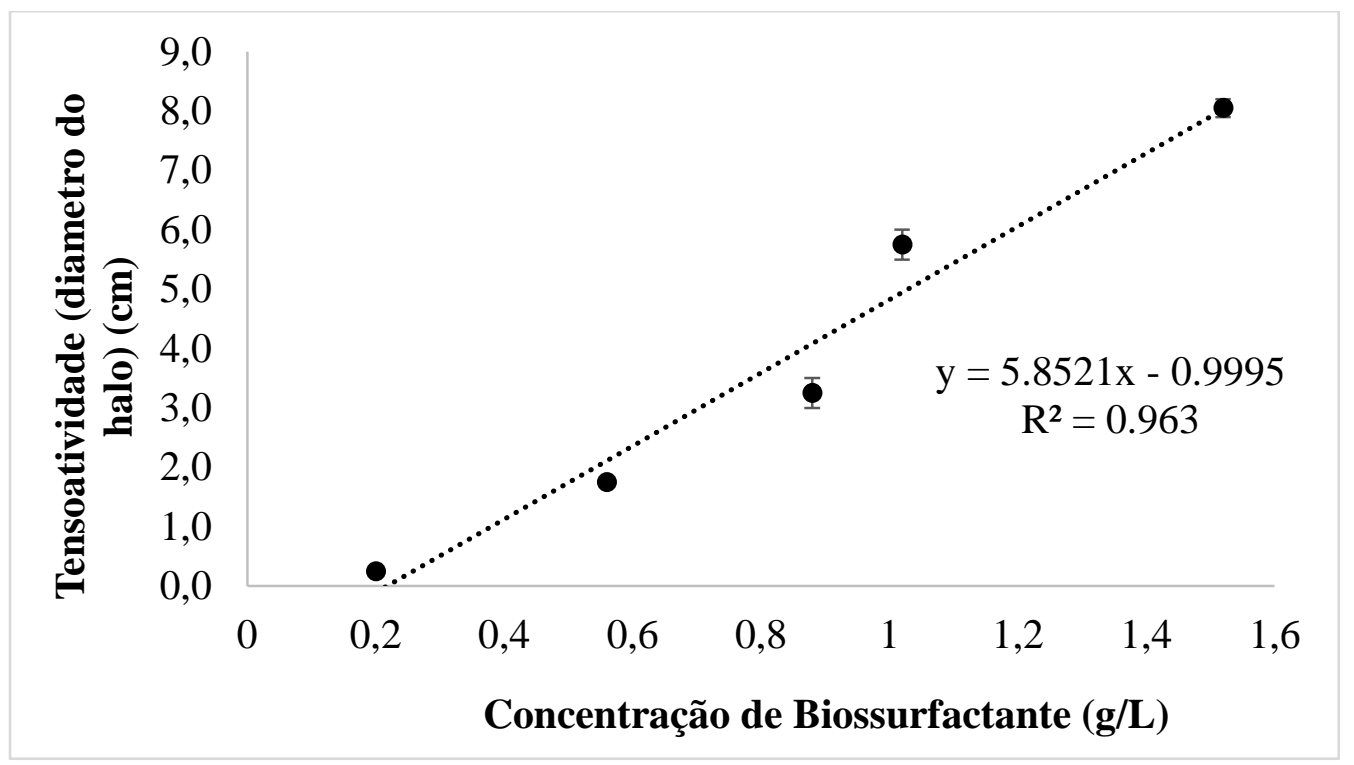

Fonte: Arquivo pessoal.

De acordo com a correlação apresentada na Figura 30, o diâmetro do halo aumenta linearmente com a concentração de biossurfactante em uma faixa de concentração de 0,2 a 1,6 $\mathrm{g} / \mathrm{L}$, com um coeficiente de correlação $\left(\mathrm{R}^{2}\right)$ de 0,96 . O teste de espalhamento da gota, utilizado no trabalho, mostrou-se uma alternativa fácil e confiável para avaliação da atividade tensoativa 
do biossurfactante e está diretamente relacionada à concentração de biossurfactante, na faixa de concentração demonstrada. Youssef e colaboradores (2004) e Walter e colaboradores (2010) já haviam descrito a correlação linear entre a quantidade de surfactante e o diâmetro do halo obtido no teste. Utilizando a equação obtida pela regressão linear, observa-se que o resultado de Ta na melhor condição no estudo da influência da concentração de sacarose e aeração, 8,05 $\mathrm{cm}$, corresponde a 1,52 $\mathrm{g} / \mathrm{L}$ de biossurfactante produzido.

O valor obtido está de acordo com os resultados reportados na literatura para este microorganismo. Manitchotpisit e colaboradores (2011) relataram valores entre 0,5 e 6,0 g/L de biossurfactante produzido dependendo da estirpe A. pullulans em fermentação submersa utilizando sacarose como substrato. Leathers e colaboradores (2015) relataram a produção de mínima de 0,5 g/L e máxima de 8,0 g/L de biossurfactante por diferentes estirpes de $A$. pullulans. A estirpe LB 83 utilizada no presente trabalho é selvagem e a sua investigação quanto à produção de biossurfactantes é inédita. $\mathrm{O}$ estudo e otimização de outros parâmentros do processo podem levar a um aumento ainda maior da produção de biossurfactante por essa levedura.

\subsection{Estudo das variáveis importantes para a produção de biossurfactante pela} levedura selecionada em processo de fermentação em estado sólido

Visando a identificação dos valores adequados das principais variáveis com influência no processo de FES (utilizando a levedura Aureobasidium pullulans LB 83 em bagaço de canade-açúcar, com meio de cultura a base de sacarose), analisou-se o tamanho médio das partículas do bagaço de cana-de-açúcar, volume de meio inicial utilizado para umedecer o bagaço, concentração celular do pré-inóculo e volume de água destilada utilizada para a extração do biossurfactante. Os intervalos entre $1,18 \mathrm{~mm}$ a $0,6 \mathrm{~mm}$ para o tamanho médio das partículas do bagaço, $10^{5}$ células $/ \mathrm{mL}$ a $10^{7}$ células $/ \mathrm{mL}$ de concentração de concentração celular, $8 \mathrm{~mL}$ a 12 $\mathrm{mL}$ de meio inicial e $15 \mathrm{~mL}$ a $25 \mathrm{~mL}$ de volume de água para a extração foram definidos baseados em condições reportadas na literatura pertinente à esta técnica (MANITCHOTPISIT et al, 2011; CAMILIOS NETO, 2010).

A determinação dos efeitos destas variáveis foi realizada por meio de planejamento fatorial completo do tipo $2^{4}$ com cinco repetições no ponto central. Foi considerada variável resposta a concentração de biossurfactante obtido por volume de meio utilizado (massa de biossurfactante por volume de meio de cultivo utilizado como solução umedecedora) (g/L). Os 
valores reais e codificados das variáveis estudadas, bem como o resultado da variável resposta para cada experimento estão apresentados na Tabela 23.

De acordo com o planejamento de experimentos (Tabela 23) foi observada uma variação nos valores de concentração de biossurfactante de aproximadamente 1,446 g/L (massa de biossurfactante por volume de meio adicionado ao bagaço), sendo o valor mínimo de 0,616 g/L encontrado na amostra 9 (0,60 mm de tamanho médio das partículas do bagaço, concentração do inóculo de $10^{7}$ cél $/ \mathrm{mL}$, volume de meio inicial de $12 \mathrm{~mL}$ e volume de extração de $25 \mathrm{~mL}$ ) e o valor máximo de 2,063 g/L para as amostras 3 e 7 (1,18 mm de tamanho médio das partículas do bagaço, volume de meio inicial de $8 \mathrm{~mL}$ e volume de extração de $25 \mathrm{~mL}$ ) variando entre os dois experimentos apenas a concentração do inóculo que para a amostra 3 foi de $10^{7}$ células $/ \mathrm{mL}$ e para a 7 de $10^{5}$ células/mL.

Tabela 23 - Níveis reais e codificados das variáveis independentes (A) tamanho médio das partículas do bagaço, (B) concentração do inóculo em células/mL, (C) volume de meio inicial e (D) volume de água para a extração, e resultados da variável resposta concentração produzida de biossurfactante para cada ensaio do planejamento estatístico $2^{4}$ completo com cinco repetições no ponto central, para estudo de condições da fermentação em estado sólido utilizando a levedura Aureobasidium pullulans LB 83 em bagaço de cana-de-açúcar.

\begin{tabular}{cccccc}
\hline Experimento & $\mathbf{A}(\mathbf{m m})$ & $\mathbf{B}($ cél./mL) & $\mathbf{C}(\mathbf{m L})$ & $\mathbf{D}(\mathbf{m L})$ & Conc. $(\mathrm{g} / \mathrm{L})$ \\
\hline 1 & $1,18(+1)$ & $1,0 \times 10^{7}(+1)$ & $12(+1)$ & $25(+1)$ & $\mathbf{1 , 0 7 9}$ \\
2 & $1,18(+1)$ & $1,0 \times 10^{7}(+1)$ & $12(+1)$ & $15(-1)$ & $\mathbf{1 , 5 7 5}$ \\
3 & $1,18(+1)$ & $1,0 \times 10^{7}(+1)$ & $8(-1)$ & $25(+1)$ & $\mathbf{2 , 0 6 3}$ \\
4 & $1,18(+1)$ & $1,0 \times 10^{7}(+1)$ & $8(-1)$ & $15(-1)$ & $\mathbf{1 , 4 3 8}$ \\
5 & $1,18(+1)$ & $1,0 \times 10^{5}(-1)$ & $12(+1)$ & $25(+1)$ & $\mathbf{0 , 7 7 1}$ \\
6 & $1,18(+1)$ & $1,0 \times 10^{5}(-1)$ & $12(+1)$ & $15(-1)$ & $\mathbf{1 , 1 2 5}$ \\
7 & $1,18(+1)$ & $1,0 \times 10^{5}(-1)$ & $8(-1)$ & $25(+1)$ & $\mathbf{2 , 0 6 3}$ \\
8 & $1,18(+1)$ & $1,0 \times 10^{5}(-1)$ & $8(-1)$ & $15(-1)$ & $\mathbf{1 , 5 8 1}$ \\
9 & $0,60(-1)$ & $1,0 \times 10^{7}(+1)$ & $12(+1)$ & $25(+1)$ & $\mathbf{0 , 6 1 7}$ \\
10 & $0,60(-1)$ & $1,0 \times 10^{7}(+1)$ & $12(+1)$ & $15(-1)$ & $\mathbf{0 , 9 0 0}$ \\
11 & $0,60(-1)$ & $1,0 \times 10^{7}(+1)$ & $8(-1)$ & $25(+1)$ & $\mathbf{1 , 0 3 1}$ \\
12 & $0,60(-1)$ & $1,0 \times 10^{7}(+1)$ & $8(-1)$ & $15(-1)$ & $\mathbf{1 , 1 5 0}$ \\
13 & $0,60(-1)$ & $1,0 \times 10^{5}(-1)$ & $12(+1)$ & $25(+1)$ & $\mathbf{1 , 0 2 8}$ \\
\hline
\end{tabular}


Continuação

\begin{tabular}{cccccc}
\hline Experimento & $\mathbf{A}(\mathbf{m m})$ & $\mathbf{B}($ cél./mL) & $\mathbf{C}(\mathbf{m L})$ & $\mathbf{D}(\mathbf{m L})$ & Conc. $(\mathbf{g} / \mathbf{L}) * *$ \\
\hline 14 & $0,60(-1)$ & $1,0 \times 10^{5}(-1)$ & $12(+1)$ & $15(-1)$ & $\mathbf{0 , 6 7 5}$ \\
15 & $0,60(-1)$ & $1,0 \times 10^{5}(-1)$ & $8(-1)$ & $25(+1)$ & $\mathbf{0 , 8 2 5}$ \\
16 & $0,60(-1)$ & $1,0 \times 10^{5}(-1)$ & $8(-1)$ & $15(-1)$ & $\mathbf{1 , 0 0 6}$ \\
17 & $0,89(0)$ & $5,05 \times 10^{6}(0)$ & $10(0)$ & $20(0)$ & $\mathbf{1 , 8 7 5}$ \\
18 & $0,89(0)$ & $5,05 \times 10^{6}(0)$ & $10(0)$ & $20(0)$ & $\mathbf{1 , 1 2 5}$ \\
19 & $0,89(0)$ & $5,05 \times 10^{6}(0)$ & $10(0)$ & $20(0)$ & $\mathbf{1 , 1 2 5}$ \\
20 & $0,89(0)$ & $5,05 \times 10^{6}(0)$ & $10(0)$ & $20(0)$ & $\mathbf{1 , 1 2 5}$ \\
21 & $0,89(0)$ & $5,05 \times 10^{6}$ & $10(0)$ & $20(0)$ & $\mathbf{0 , 7 5 0}$ \\
\hline
\end{tabular}

*Valores codificados das variáveis estudadas encontram-se entre parênteses. ** massa de biossurfactante produzido por volume de meio (solução umedecedora) utilizado. Fonte: Arquivo pessoal

Os resultados foram analisados estatisticamente em função das variáveis estudadas. Os níveis de significância destas variáveis, suas interações e efeitos podem ser visualizados no gráfico de Pareto (Figura 31).

Figura 31 - Gráfico de pareto de acordo com resultados das variáveis independentes (A) tamanho médio das partículas do bagaço, (B) concentração do inóculo em células $/ \mathrm{mL},(\mathrm{C})$ volume de meio inicial de meio e (D) volume de água para a extração, referentes aos resultados do planejamento estatístico $2^{4}$ completo com cinco pontos centrais, para estudo de condições da FES da levedura Aureobasidium pullulans em bagaço de cana-de-açúcar.

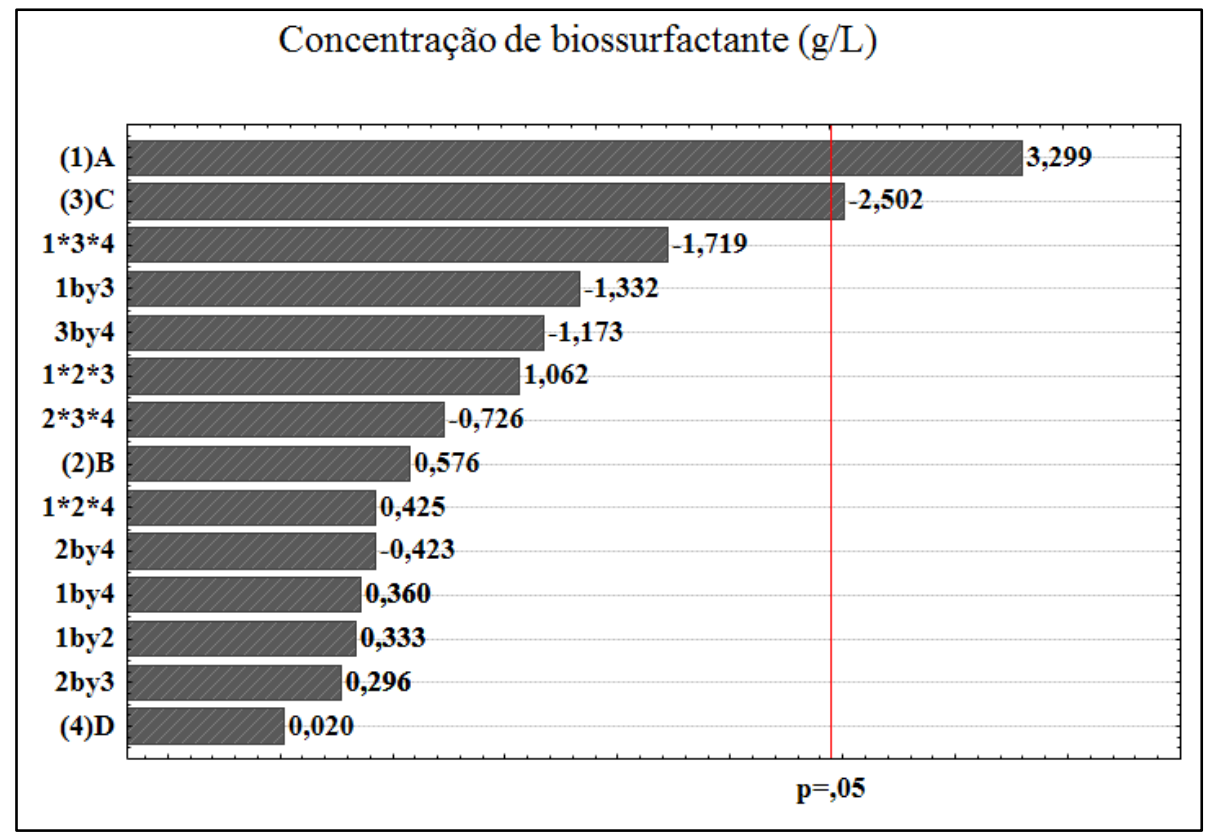

*Estimativa do efeito padronizado (valor absoluto). Fonte: Arquivo Pessoal 
Foi observado que as variáveis A (tamanho médio das partículas do bagaço) e C (volume de meio) foram significativas para a variável resposta (concentração de biossurfactante). As demais variáveis e interações não apresentaram efeito significativo.

O aumento do tamanho médio das partículas do bagaço (efeito positivo) e a redução do volume de meio (efeito negativo) indicam o aumento da produção de biossurfactante. Entretanto, em condições práticas observa-se a inviabilidade de extrapolar os níveis máximo e mínimo destas variáveis, uma vez que o aumento do tamanho médio das partículas do bagaço, bem como a redução do volume de meio inicial dificultariam a homogeneização do meio reacional, não permitindo a exequibilidade da FES. Sendo assim, as condições definidas para o processo foram: $1,18 \mathrm{~mm}$ de tamanho médio das partículas de bagaço, concentração celular do inóculo de $10^{6}$ células $/ \mathrm{mL}, 8 \mathrm{~mL}$ de meio de cultura inicial e $15 \mathrm{~mL}$ de água destilada para extração.

O maior tamanho médio de partícula e menor volume de meio favoreceram a produção de biossurfactantes por A. pullulans LB 83, corroborando com os resultados encontrados no planejamento realizado em biorreator (item 5.6.3), em que a aeração foi um fator que influenciou significativamente na produção de biossurfactantes. Este comportamento foi verificado uma vez que as partículas de maior tamanho médio e a adição de menor volume de meio proporcionou menor compactação durante o processo de FES, o que favoreceu a transferência de oxigênio no processo. Camilios Neto e colaboradores (2008) ao estudar a produção de biossurfactantes por Pseudomonas aeruginosa UFPEDA 614 em fermentação em estado sólido também relataram que a compactação (no caso do trabalho dos autores causado por adição de óleo ao bagaço de cana-de-açúcar) também resultou em uma redução no rendimento da fermentação devido à redução da aeração.

O fato de os valores de concentração inicial de inóculo e volume de extração não apresentarem efeitos significativos podem ser explicados possivelmente pelo estreito intervalo utilizado de concentração celular inicial, e, no caso da extração, pelo fato de o menor volume já ser suficiente para a extração efetiva do biossurfactante, não havendo necessidade de aumento deste volume.

É importante destacar que o valor máximo de concentração de biossurfactante obtido na fermentação em estado sólido (2,06 g/L) foi ainda maior que o maior valor observado nos testes conduzidos em fermentação submersa $(1,52 \mathrm{~g} / \mathrm{L})$, obtido pela correlação do valor de tensoatividade $(\mathrm{cm})$. O presente trabalho é de caráter inovador, não havendo relatos da produção de biossurfactantes por fermentação em estado sólido por $A$. pullulans, e, portanto, não se verifica resultados comparativos ao rendimento deste processo. De fato, a literatura pertinente 
apresenta produção de biosurfactantes, entretanto, utilizando outros micro-organismos e em outros tipos de processos. Por exemplo, Camilios Neto e colaboradores (2011), utilizando a bactéria Pseudomonas aeruginosas, em processo de FES com glicerol e óleo de soja como fontes de carbono, reportaram a produção de $45 \mathrm{~g} / \mathrm{L}$ de biossurfactantes do tipo ramnolipídeos. Em outro trabalho, Bueno e colaboradores (2014), relataram a produção máxima de 1,6 g/L de biossurfactantes produzidos por Bacillus subtilis em FES utilizando bagaço de cana-de-açúcar como substrato. Em uma outra investigação de produção de biosurfactantes, entretanto, em fermentação submersa, Manitchotpisit e colaboradores (2011), relataram valores entre 0,5 e 6,0 g/L de biossurfactante produzido por A. pullulans, dependendo da cepa utilizada. De fato, apesar das diferenças de condições de processos, verifica-se a potencialidade do uso da levedura Aureobasidium pullulans LB 83 para a produção de biosurfactantes em FES.

\subsection{Comparação de rendimento entre os processos de fermentação submersa e} fermentação em estado sólido para a produção de biossurfactante por A. pullulans LB 83 e avaliação do processo de extração

Após a definição das condições otimizadas do processo de fermentação em estado sólido, foi realizada a comparação entre os rendimentos dos processos, submerso e em estado sólido, a partir do mesmo inóculo inicial, afim de minimizar outras interferências além da diferença na forma de condução do processo. A FS, nesse caso, foi conduzida em frascos Erlenmeyer de $50 \mathrm{~mL}$, utilizando a metodologia tradiciolal já reportada na literatura em trabalhos como os de Manitchotpisit e colaboradores (2011) (metodologia detalhada no item 4.5). A FES foi conduzida utilizando as condições otimizadas obtidas no presente trabalho $(1,18$ mm de tamanho médio das partículas de bagaço, concentração celular do inóculo de $10^{6}$ cél $/ \mathrm{mL}$, $8 \mathrm{~mL}$ de meio de cultura inicial e $15 \mathrm{~mL}$ de volume para extração).

Com o objetivo de minimizar as perdas durante a extração da FES, que poderiam levar à subquantificação do biossurfactante produzido na FES, foram testados dois tipos de extração: utilizando-se água destilada, seguido da extração de biossurfactante com butanona a partir do extrato aquoso; e a extração diretamente com a adição de butanona do bagaço fermentado (item 4.12.20). Os resultados obtidos estão apresentados na Tabela 24. A diferença entre as médias foi avaliada pelo teste de Tukey (95\% de confiança). 
Tabela 24 - Comparação entre os rendimentos obtidos na fermentação submersa e fermentação em estado sólido após extração com água e com butanona

\begin{tabular}{ccc}
\hline Processo & Extração & Rendimento $(\mathbf{g} / \mathbf{L})$ \\
\hline FS & Butanona $(1: 1)$ & $0,6250^{\mathrm{a}}$ \\
FES & $15 \mathrm{~mL} \mathrm{de} \mathrm{H}_{2} \mathrm{O}+$ Butanona $(1: 1)$ & $1,0782^{\mathrm{a}}$ \\
FES & $15 \mathrm{~mL}$ de butanona & $1,875^{\mathrm{a}}$ \\
\hline
\end{tabular}

*FS: fermentação submersa; FES: fermentação em estado sólido. Médias seguidas de letras distintas minúsculas nas linhas, indicam diferenças estatísticas $(\mathrm{p}>0,05)$ pelo Teste de Tukey

Fonte: Arquivo pessoal.

Apesar da diferença nos valores numéricos obtidos, de acordo com a análise estatística não houve diferença significativa no rendimento da produção de biossurfactante entre a FS e FES, sendo a comparação feita utilizando a massa de biossurfactante produzida por $\mathrm{mL}$ (no caso da FES a massa de biossurfactante produzido por volume meio base de sacarose inicial utilizado). Também não houve diferença significativa entre os métodos de extração na FES, utilizando-se diretamente a butanona ou realizando a aextração primeiramente com água e em seguida com butanona.

Apesar de não haver diferença significativa em termos de rendimento, visando um processo industrial, a eliminação de uma etapa no processo de extração e a redução na utilização de água leva à economia do processo, e por isso o processo utilizando-se diretamente a butanona para extração da FES mostra-se favorável.

As concentrações de biossurfactantes produzidas após 168 h, reportados na Tabela 24 também estão de acordo com os resultados reportados na literatura para este micro-organismo, como discutido anteriormente. Entretanto, observou-se que o máximo de 2,62 g/L obtido nos testes de otimização da FES não foram repetidos por nenhum dos métodos de produção utilizados nesta etapa do trabalho. Kurosawa e colaboradores (1994) já haviam relatado que os rendimentos na produção de biossurfactante observados para essa levedura eram instáveis, e talvez por isso essa diferença foram observadas. Esse fato reintera a importância de se conduzir o teste comparativo a partir do mesmo inóculo inicial.

O processo de FES apresenta-se promissor, uma vez que apresentou rendimentos próximos àqueles obtidos na FS e evita problemas operacionais como a formação de espuma e aumento de viscosidade do meio, observados no presente trabalho nos processos fermentativos utilizando meio líquido. Além disso é uma alternativa para a produção de uma biomolécula de 
alto valor agregado a partir de um substrato agrícola, como o bagaço de cana-de-açúcar, tornando o processo ainda mais sustentável.

\subsection{Extração e caracterização bioquímica do biossurfactante}

A extração do biossurfactante com butanona em funil de separação resultou da formação de um líquido amarelo esverdeado que apresentou fluorescência quando visualizado à ultravioleta, como demonstrado na Figura 32.

Figura 32 - Extração do biossurfactante com butanona e verificação de fluorescência

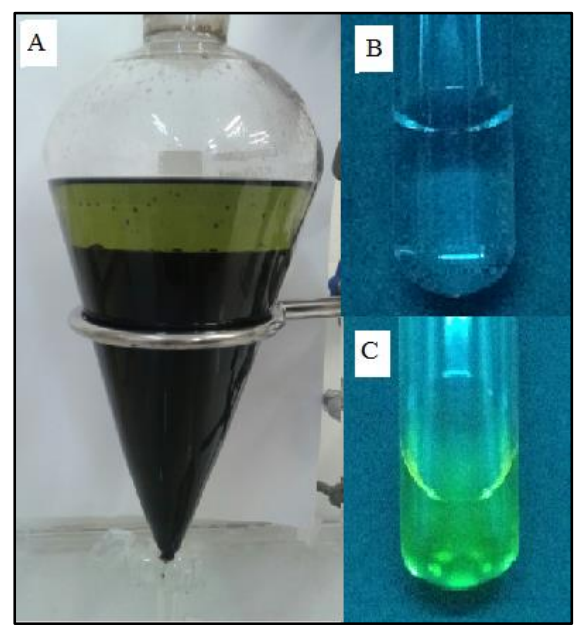

A: Extração do biossurfactante com butanona; B: Tubo com butanona sem biossurfactante (não possui fluorescência); C: Tubo com butanona na presença de biossurfactante (possui fluorescência). Fonte: Arquivo pessoal.

A observação da fluorescência do biossurfactante extraído está de acordo com os resultados de Manitchotpisit e colaboradores (2011), que ao estudar a produção de "heavy oils"de 21 isolados de Aureobasidium pullulans relatou pela primeira vez a fluorescência deste metabólito. Este resultado reforça a possibilidade de que a molécula produzida no presente trabalho é o mesmo poliol lipídeo relatado por Manitchotpisit e colaboradores (2011) em seus trabalhos.

Para confirmação da ausência de compostos de natureza bioquímica diferente de polióis lipídeos foram feitos testes bioquímicos para determinação de açúcares redutores, proteínas e lipídeos, utilizando a amostra de biossurfactante hidrolisada. Também foi feita análise cromatográfica (HPLC) utilizando padrões de manitol e arabitol para confirmar a presença destes polióis na molécula de biossurfactante produzida (Figura 33). Da mesma forma, foi 
realizada a microscopia do meio antes e após a extração, para verificar modificações na morfologia celular (Figura 34).

Figura 33 - Cromatograma da análise da fração polar do biossurfactante hidrolisado em HPLC

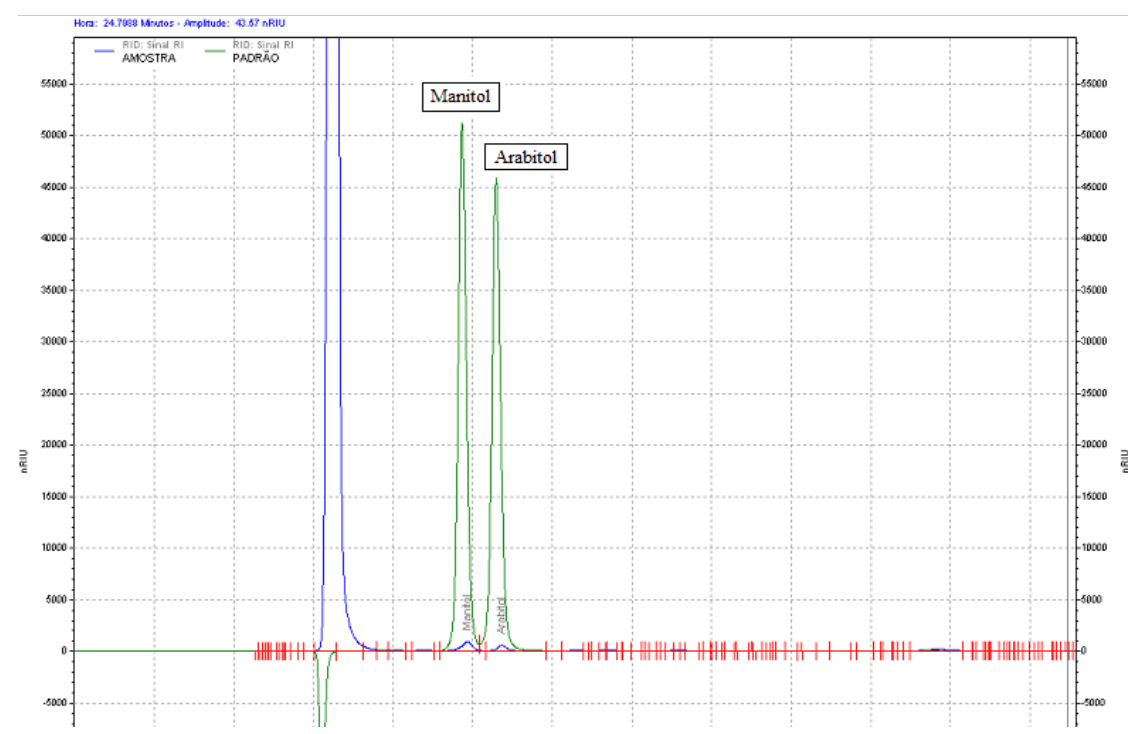

Fonte: Arquivo pessoal.

Figura 34 - Aspecto da morfologia celular de Aureobasidium pullulans LB 83 antes (A) e após (B) a extração com butanona. (Microscopia óptica, aumento de 400x)

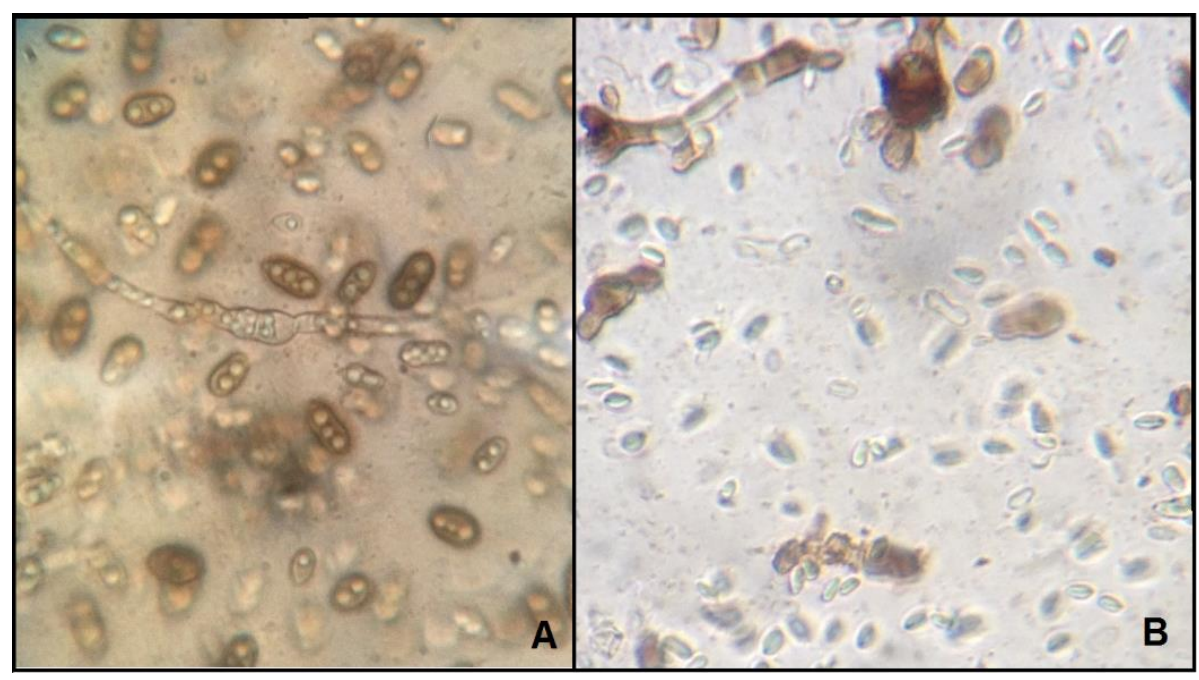

Fonte: Arquivo pessoal.

A análise cromatográfica da fração polar do biossurfactante hidrolisado apresentou picos nos tempos de retenção dos compostos arabitol e manitol (Figura 33), sendo que nenhum outro pico foi observado. 
De acordo com a observação microscópica (Figura 34), pode-se observar que a butanona atinge também o meio intracelular, extraindo o biossurfactante retido nas estruturas de reserva do micro-organismo. Já havia sido reportado na literatura a capacidade da levedura A. pullulans produzir biossurfactantes intra e extracelular, sendo observadas estruturas intracelulares fluorescentes (MANITCHOTPISIT et al., 2011). As estruturas intracelulares de reserva de "heavy oils", ou biossurfactantes, descritas no trabalho de Manitchotpisit e colaboradores (2011) são muito semelhantes àquelas observadas na Figura 34A, as quais encontram-se vazias após a extração (Figura 34B), o que demonstra a efetividade da extração com butanona para este tipo de biossurfactante.

Para a caracterização bioquímica do biossurfactante extraído e hidrolisado (de acordo com metodologia proposta por Peixoto (2008), foi avaliada a presença de proteína (BRADFORD, 1976), açúcares redutores (MILLER, 1959) e lipídeos (IZARD; LIMBERGER, 2003). Os testes realizados indicaram a ausência de proteína e açúcares redutores na estrutura do biossurfactante, por outro lado, a análise de lipídeos apresentou resultado positivo.

As análises realizadas foram apenas qualitativas para avaliar a composição bioquímica do biossurfactante extraído da fermentação. De acordo com os resultados encontrados pode-se verificar que este é um biossurfactante do tipo poliól lipídeo que possui os polióis manitol e arabitol como parte polar da molécula. Este resultado indica a similaridade da molécula produzida pela levedura Aureobasium pullulans SSS33 com a molécuta produzida em outros trabalhos utilizando esta levedura (PRICE et al., 2013, MANITCHOTPISIT et al, 2011; LIU et al, 2104).

\subsection{Avaliação da atividade tensoativa do biossurfactante produzido em relação à} surfactantes sintéticos comerciais

A performance do biossurfactante na concentração de 1,5 g/L no teste de espalhamento da gota foi comparada com a dos surfactantes sintéticos comerciais Tween 20, Tween 80 e dodecil sulfato de sódio na concentração de $10 \mathrm{~g} / \mathrm{L}$. Os surfactantes sintéticos apresentaram valores de 6,5; 5,0 e 4,8 cm de abertura de halo, respectivamente, no teste de espalhamento da gota, enquanto o biossurfactante apresentou $7,7 \mathrm{~cm}$. Esse resultado demonstra que o poliol lipídeo produzido por Aureobasidium pullulans LB 83, mesmo numa concentração 6,67 vezes menor, apresentou maior tensoatividade que os surfactants comerciais, o que indica a primissora aplicabilidade do biossurfactante produzido. 
De acordo com Santos e colaboradores (2016) a eficiência e eficácia são características essenciais de um bom surfactante. A eficiência é medida pelo $\mathrm{CMC}^{*}$ enquanto a eficácia está relacionada com a tensoatividade. O resultado de maior atividade tensoativa do biosurfactante produzido no presente trabalho demosntrou que o mesmo possui maior eficácia que os surfactantes sintéticos comerciais testados. Com relação à eficiência, o $\mathrm{CMC} *$ reportado na literatura para Tween 20, Tween 80 e dodecil sulfato de sódio são $60 \mu \mathrm{g} / \mathrm{mL}, 15 \mu \mathrm{g} / \mathrm{mL}$ e

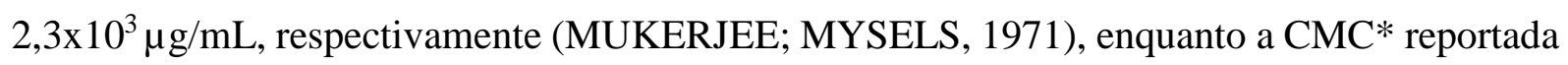
para o poliol lipídio produzido por A. pullulans é de $10 \mu \mathrm{g} / \mathrm{mL}$ (ISODA; NAKAHARA, 1997). O biossurfactante é mais eficiente mesmo quando comparado com surfactantes sintéticos do tipo Tween, conhecidos pelo baixo valor de CMC*. Estes dados destacam ainda mais as características deste biossurfactante para diversas aplicações industriais e ambientais.

A eficiencia e eficácia das moléculas surfactants variam porque, além da concentração, o peso molecular e a natureza das frações hidrofílicas e hidrofóbicas da molécula são determinantes para a sua tensoatividade. Por exemplo, alguns biossurfactantes possuem maior tensoatividade, como os glicolipídeos e alguns lipopeptídeos de cadeia curta (de baixo peso molecular), enquanto outros apresentam maior atividade emulsificante, como os lipopeptídeos poliméricos (de alto peso molecular) (SATPUTE et al., 2010).

\subsection{Avaliação do potencial da utilização do biossurfactante produzido por}

\section{Aureobasidium pullulans LB 83 em processo de biorremediação}

Quando os compostos de hidrocarbonetos do petróleo entram em contato com o solo, como no caso de acidentes petroquímicos, estes se ligam aos componentes do solo e são difíceis de serem removidos devido à sua hidrofobicidade, causando grandes impactos econômicos e principalmente ambientais (XUE et al., 2015; BEZZA; CHIRWA, 2015). Por isso têm se destacado o desenvolvimento e implementação de tecnologias inovadoras para a remoção desses contaminantes, como, por exemplo, a utilização de biossurfactantes (SILVA et al., 2014b).

A utilização de biosurfactantes tem sido explorada nas principais etapas da cadeia de produção de petróleo, como extração, transporte e armazenamento. Isso ocorre devido à sua capacidade de emulsionar hidrocarbonetos, aumentando a sua solubilidade em água, diminuindo a tensão superficial e aumentando o deslocamento do óleo. Além disso, as vantagens como biodegradabilidade, baixa toxicidade e melhor funcionalidade em condições 
extremas em comparação aos surfactantes químicos fazem essas biomoléculas ainda mais promissoras (BATISTA et al., 2010).

Não há relatos na literatura da utilização do biossurfactante produzido por Aureobasidium pullulans em processos de biorremediação. Entretanto, o biosurfactante produzido no presente trabalho apresentou a capacidade de remover petróleo residual de areia contaminada com petróleo, mesmo em baixas concentraçãoes (Tabela 25).

Tabela 25 - Remoção de petróleo residual de areia contaminada artificialmente utilizando-se soluções de biossurfactante (BS) $(0,01$ e $0,05 \%$ m/m), solução de dodecil sulfato de sódio (SDS) $(0,01$ e 0,05\% $\mathrm{m} / \mathrm{m})$ e água desmineralizada $\left(\mathrm{H}_{2} \mathrm{O}\right)$ como soluções removedoras

\begin{tabular}{cc}
\hline Solução removedora & Porcentagem de recuperação $(\% \mathbf{~ m} / \mathbf{m})$ \\
\hline BS $0,01 \%(\mathrm{~m} / \mathrm{m})$ & $73,72 \pm 1,68 \mathrm{~b}$ \\
\hline BS $0,05 \%(\mathrm{~m} / \mathrm{m})$ & $\mathbf{7 8 , 4 2} \pm \mathbf{2 , 2 2 b}$ \\
\hline SDS $0,01 \%(\mathrm{~m} / \mathrm{m})$ & $58,05 \pm 3,60 \mathrm{a}$ \\
\hline SDS $0,05 \%(\mathrm{~m} / \mathrm{m})$ & $75,00 \pm 2,20 \mathrm{~b}$ \\
\hline $\mathrm{H}_{2} \mathrm{O}$ & $46,65 \pm 7,38 \mathrm{a}$
\end{tabular}

Médias seguidas de letras distintas minúsculas nas linhas, indicam diferenças estatísticas $(p>0,05)$ pelo Teste de Tukey

Fonte: Arquivo pessoal.

Os resultados obtidos (Tabela 25) demonstraram que, numericamente, a melhor ação de remoção do petróleo da areia contaminada foi obtida quando se utilizou o biossurfactante produzido por Aureobasidium pullulans LB 83 na concentração de 0,05\%. Estatísticamente, a remoção utilizando-se biossurfactante $0,01 \%$ e $0,05 \%$ não apresentou diferença significativa quando comparado aos resultados obtidos quando se utilizou SDS 0,05\%. Entretanto, na mesma concentração de $0,01 \%$, a remoção de petróleo nas amostras tratadas com biossurfactante foi maior que àquelas tratadas com SDS, o que demonstrou o grande potencial desta biomolécula em processos de biorremediação.

Quando comparado a resultados encontrados na literatura para outros tipos de biossurfactantes foi observado que a ação do biossurfactante produzido por A. pullulans LB 83 apresentou resultados promissores com relação a outros biossurfactantes já relatados. Por exemplo, Luna e colaboradores (2009) reportaram a remoção de 63,3 \% do petróleo, utilizando uma solução 1,5\% de biossurfactante produzido por Candida glabrata UCP1002, o que demonstra que o biossurfactante produzido no presente trabalho foi mais efetivo em menores 
concentrações. Pereira e colaboradores (2013) avaliou a recuperação de óleo residual de areira utilizando soluções 0,01\% biossurfactante produzido por três estirpes de Bacillus subtilis e relatou porcentagens de recuperação entre 18,8 $\pm 1,1$ e 22,1 $\pm 2,4 \%$, enquanto Beza e Chirwa (2015) reportaram recuperação de 84,6 \pm 7,1\% de óleo de motor em areia contaminada utilizando o extrato bruto da fermentação utilizando Bacillus subtilis CN2 como solução de remoção.

Além do potencial da sua utilização em processos de biorremediação, a capacidade de remoção de petróleo residual apresentada pelo biossurfactante demonstra também o potencial da utilização do fungo leveduriforme A. pullulans em processos de recuperação melhorada do petróleo (MEOR) em petroquímicas. MEOR consiste na recuperação terciária de óleo com a utilização de micro-organismos ou seus produtos metabólicos para recuperar óleo residual no processo de extração do petróleo (SILVA et al., 2014b). Os micro-organismos produzem polímeros e biossurfactantes, que diminuem a tensão superficial óleo-rocha, diminuindo as forças capilares que impedem o movimento do óleo pelos poros da rocha. Os biossurfactantes também auxiliam na emulsificação e degradação do filme de óleo na rocha. Por isso esse processo aumenta a recuperação do petróleo de um reservatório esgotado e aumenta a vida útil do reservatório de extração de petróleo (SILVA et al., 2014b). 


\section{CONCLUSÕES}

- É possível a produção de biossurfactantes por leveduras utilizando processo de fermentação em estado sólido em bagaço de cana-de-açúcar, o que traz vantagens por ser um material abundante, disponível e de baixo custo, além de proporcionar níveis de produção razoáveis e não reter o biossurfactante produzido.

- Dentre as 37 leveduras testadas, 17 apresentaram produção de biossurfactante em fermentação submersa. Dentre as leveduras testadas em FES, a levedura A. pullulans LB 83 foi aquela que apresentou maior atividade tensoativa e emulsificante empregando o bagaço de cana-de-açúcar como matriz sólida.

- A levedura Aureobasidium pullulans LB 83 foi capaz de produzir biossurfactantes por fermentação em estado sólido utilizando o bagaço de cana-de-açúcar como substrato inerte e sacarose como fonte de carbono. Não houve produção de enzimas lignocelulolíticas, o que confirma que os açúcares da estrutura do bagaço não foram utilizados como fonte de carbono.

- A aeração e a concentração da fonte de carbono foram fatores importantes para o processo de produção de biossurfactantes e também influenciaram na cor (maior ou menor produção de melanina) e na viscosidade (maior ou menor produção de pululana) do meio durante o processo fermentativo. A adição de indutores (glicerol e óleo de soja) não agregou vantagens à produção de biossurfactantes por A. pullulans LB 83.

- Para o processo de FES foi vantajoso um maior tamanho médio das partículas de bagaço e menor volume de mio adicionado ao bagaço de cana-de-açúcar. Esses fatores foram importantes por reduzirem a compactação do bagaço de cana de açúcar, permitindo maior aeração no processo de FES.

- O biossurfactante produzido (poliol lipídeo) possui potencial para aplicação em processos de biorremediação e apresenta melhor recuperação de petróleo quando comparado com o surfactante sintético dodecil sulfato de sódio.

- Os resultados apontam a potencialidade da produção de biossurfactantes por Aureobasidium pullulans LB 83 por processo de fermentação em estado sólido utilizando o bagaço de cana-de-açúcar como um processo alternativo, garantindo resultados próximos aos obtidos por fermentação submersa com a vantagem de evitar o problema da formação de espuma durante o processo. 


\section{PERSPECTIVAS PARA TRABALHOS FUTUROS}

- Purificar e caracterizar estruturalmente a molécula de biossurfactante produzida pela levedura A. pullulans LB 83, afim de comparar a estrutura obtida por essa levedura com aquelas já relatadas na literatura para essa espécie. Além de avaliar se a forma de cultivo (fermentação submersa ou fermentação em estado sólido) proporciona alguma alteração na molécula produzida.

- Avaliar a co-produção de pululana na fermentação, uma vez que a condição de cultivo para a melhor produção de biossurfactante também levou à maior viscosidade do meio de cultivo. Esse estudo é interessante para abordar a questão de qual porcentagem de carbono consumido é convertido em biomassa em função de outros produtos.

- Testar diferentes aplicações para o biossurfactante purificado, como sua atividade antimicrobiana, anticâncer e na inibição da formação de biofilmes.

- Avaliação da utilização de fontes alternativas de carbono como meio de cultivo adicionado ao bagaço, como o hidrolisado hemicelulósico e celulósico (uma vez que a levedura apresentou a capacidade de assimilar e produzir biossurfactantes também a partir de glicose e xilose). Adicionalmente, avaliar a utilização da celulignina como substrato inerte, fazendo desta forma o uso integral do bagaço de cana-de-açúcar no processo.

- Estudar diferentes configurações de reatores de fermentação em estado sólido que possam se adequar ao processo de produção de biossurfactante visando estudos de aumento de escala. Podem ser avaliados os reatores de bandeja, que são reatores sem agitação de leito, e, portanto, o que mais se aproxima da forma que a FES foi conduzida no presente trabalho. Também podem ser realizados estudos em reatores de coluna e de respirometria para melhor avaliar a possibilidade de utilização do reator piloto com aeração forçada, um importante parâmetro para a produção de biossurfactante por $A$. pullulans LB 83 


\section{REFERÊNCIAS}

ABDEL-MAWGOUD, A. M.; ABOUlWAFA, M. M.; HASSOUNA, N. A. Characterization of surfactin produced by Bacillus subtilis isolate BS5. Applied Biochemistry and Biotechnology, v. 150, n. 3, p. 289-303, 2008.

ACCOSINI, F. R.; MUTTON, M. J. R.; LEMOS, E. G. M.; BENINCASA, M. Biosurfactants production by yeasts using soybean oil and glycerol as low cost substrate. Brazilian Journal of Microbiology, v. 43, n. 1, p. 116-125, 2012.

ADAMCZAK, M.; BEDNARSK, B. Influence of medium composition and aeration on the synthesis of biosurfactants produced by Candida Antarctica. Biotechnology Letters, v. 22, p. 313-316, 2000.

ADAMSON, A. W.; GAST, A. P. Physical Chemistry of Surfaces. New York: John Wiley \& Sons, 1997. $755 \mathrm{p}$.

AGUIRRE, C. A. P.; BASTOS, R. G.; CARVALHO, A. I.; ALEGRE, R. M. The influence of process parameters in production of lipopeptide iturin A using aerated packed bed bioreactors in solid-state fermentation. Bioprocess Biosystems Engeneering, v. 37, p. 1569-1576, 2014.

AL-BAHRY, S. N. et al. Isolation and characterization of biosurfactant/biopolymer producing spore forming bacteria from oil contaminated sites and oil field of Oman. APCBEE Procedia, v. 5 , p. $242-246,2013$.

ALBANO, T. J. S. Development of production process for new-to-nature biosurfactant. 2014. 61f. Dissertação (Mestrado em Engenharia Biológica) - Instituto Técnico de Lisboa, Lisboa, 2014.

ALBRECHT, A.; RAU, U.; WAGNER, F. Initial steps of sophoroselipid biosynthesis by Candida bombicola ATCC 22214 grown on glucose. Applied Microbiology and Biotechnology, v. 46, p. 67-73, 1996.

AUDET, J.; LOUNES, M.; THIBAULT, J. Pullulan fermentation in a reciprocating plate bioreactor. Bioprocess and Biosystems Engineering, v. 15, p. 209-214, 1996.

AMARAL, P. F. F. et al. Biosurfactants from Yeasts: Characteristics, Production and Application, In: Ramkrishna Sen. (Org.). Biosurfactants. Biosurfactants. New York: Springer Science+Business media, LCC, Landes Bioscience, p. 236-249, 2010.

ANASTASSIADIS, S.; REHM, H. J. Continuous gluconic acid production by Aureobasidium pullulans with and without biomass retention. Eletronic Journal of Biotechnology, v. 9, n. 5, p. 1-11, 2006.

APARNA A.; SRINIKETHAN G.; SMITHA H. Effect of addition of biosurfactant produced by Pseudomonas sps. on biodegradation of crude oil. International Proceedings of Chemical, Biological and Environmental Engineering (IPCBEE), v.6, p. 71-75, 2011. 
ARIMA, K.; KAKINUMA, A.; TAMURA, G. Surfactin, a crystalline peptide lipid surfactant produced by Bacillus subtilis: isolation, characterization and its inhibition of fibrin clot formation. Biochemical and Biophysical Research Communication, v. 31, p. 488-494, 1968.

ARCURI, S. L. et al. Yeasts found on an ephemeral reproductive caste of the leaf-cutting ant Atta sexdens rubropilosa. Antonie van Leeuwenhoek, v. 106, n. 3, p. 475-487, 2014.

ATTWOOD, D.; FLORENÇA, A. T. Surfactant systems, their chemistry, pharmacy and biology. London: Chapman And Hall, 1987. 794 p.

BAILEY, M. J.; BIELY, P.; POUTANEN, K. Interlaboratory testing of methods for assay of xylanase activity. Journal of Biotechnology, v. 23, p. 257-270, 1992.

BANAT, I. M. The isolation of a thermophilic biosurfactant producing Bacillus sp. Biotecnology Letters, v. 15, n. 6, p. 591-594, 1993.

BANAT, I. M. Biosurfactants production and use in microbial enhanced oil recovery and pollution remediation: a review. Bioresource Technology, v. 51, p. 1-12, 1995.

BANAT, I. M.; MAKKAR, R. S.; CAMEOTRA, S. S. Potencial commercial applications of microbial surfactants. Applied Microbiology and Biotechnolog, n. 53, p. 495-508, 2000.

BANAT, I. M. et al. Microbial biossurfactants production, application and future potential. Applied Microbiology and Biotechnology, v. 87, p. 427-444, 2010.

BARTH, G.; GAILLARD, C. Physiology and genetics of the dimorphic fungus Yarrowia lipolytica. FEMS Microbilogy Reviews, v. 19, n. 4, p. 219-237, 1997.

BATISTA, R. M. et al. Effect of medium components on the production of a biosurfactant from Candida tropicalis applied to the removal of hydrophobic contaminants in soil, Water Environment Research, v. 82, n. 5, p. 418-425, 2010.

BELGACEM, Z. B. et al. Biosurfactant production by Pseudomonas strains isolated from floral nectar. Journal of Applied Microbiology, v. 118, n. 6, p. 1370-1384, 2015.

BENINCASA, M; ACCORSINI, F. R. Pseudomonas aeruginosa LBI production as na integrated process using the wastes from sunflower-oil refining as a substrate. Bioresource Technology, v. 99, p. 3843-3849, 2008.

BENTO, F. M. et al. Diversity of biosurfactant producing microorganisms isolated from soils contaminated with diesel oil. Microbiological Research, v. 160, n. 3, p. 249-255, 2005.

BERNHEIMER, A. W.; AVIGAD, L. S. Nature and properties of a cytological agent produced by Bacillus subtilis. Journal of General Microbiology, v. 61, p. 361-369, 1970.

BEZZA, F. A.; CHIRWA, E. M. N. Production and applications of lipopeptide biosurfactant for bioremediation and oil recovery by Bacillus subtilis CN2. Biochemical Engineering Journal, v. 101, p. 168-178, 2015. 
BISCHOFF, K. M. et al. Liamocin oil from Aureobasidium pullulans has antibacterial activity with specificity for species of Streptococcus. The Journal of Antibiotics, v. 68, p. 642-645, 2015

BODOUR, A. A., MAIER, R. M. Application of a modified drops collapse technique for surfactant quantitation and screening of biosurfactant producing of microorganisms, Journal of Microbiological Methods, n. 32. p. 273-280, 1998.

BOGNOLO, G. Biossurfactants as emulsifying agents for hydrocarbons. Colloids and Surfaces A: Physicochemical and Engineering Aspects, v. 152, p.41-52, 1999.

BORATO, D.; GALÃO, O. F.; MOREIRA, I. Detergentes naturais e sintéticos um guia técnico. Londrina: Eduel, 182 p., 1999

BRADFORD, M. M. A rapid and sensitive method for the quantitation of microgram quantities of protein utilizing the principle of protein-dye bindin. Analitycal Biochemistry, v. 72, n. 1-2 p. $248-254,1976$.

BRUMANO, L. P.; SOLER, M. F.; SILVA, S. S. Recent advances in sustainable production and application of biosurfactants in brazil and latin america. Industrial Biotechnology, v. 12, n. 1, p. 31-39, 2016.

BUENO, S. M. Bactérias produtoras de biossurfactantes: isolamento, produção, caracterização e comportamento num sistema modelo. 2008. Tese (Doutorado em Engenharia e Ciência de Alimentos) - Instituto de Instituto de Biociências, Letras e Ciências Exatas, Universidade Estadual Paulista "Júlio de Mesquita Filho", São José do Rio Preto, SP, 2008.

BUENO, S. M.; SILVA, A. N.; GARCIA-CRUZ, C. H. Estudo da produção de biossurfactante em caldo de fermentação. Quimica Nova, v.33, n. 7, p. 1572-1577, 2010.

BUENO, G. F. Produção de biossurfactantes utilizando resíduos agroindustriais como substrato. 2014. 138 f. Tese (Doutorado em Ciências de Alimentos) - Universidade Estadual Paulista "Julio de Mesquita Filho", Instituto de Biociências, Letras e Ciências Exatas, 2014.

BUGAY, C. Biossurfactantes produzidos por Bacillus sp.: estudos de produção e caracterização. 82f. Dissertação (Mestrado em Química Orgânica) - Universidade Federal do Paraná, Curitiba, PR, 2009.

CADETE, R. M. Isolamento e caracterização de leveduras fermentadoras de D-xilose, Larabinose ou D-celobiose e produtoras de celulases e xilanases associadas a madeira em decomposição. Dissertação (Mestrado em Microbiologia) - Universidade Federal de Minas Gerais, Belo Horizonte, MG, 2009.

CAMILIOS NETO, D. Produção de ramnolipídeos por fermentação em estado sólido. 2010. Tese (Doutorado em Bioquímica) - Universidade Federal do Paraná, Curitiba, PR, 2010.

CAMILIOS NETO, D. et al. Production of rhamnolipids in solid-state cultivation using a mixture of sugarcane bagasse and corn bran supplemented with glycerol and soybean oil. Applied Microbiology and Biotechnology, v. 89, n. 5, p. 1395-1403, 2011. 
CAMPOS, J. M. et al. Microbial Biosurfactants as Additives for Food Industries, Biotechnology Progress, v.29, n. 5, p. 1097-1108, 2013.

CARRILLO, P. G. et al. Isolation and selection of biosurfactant-producing bacteria. World Journal of Microbiology and Biotechnology, n. 12, p. 82 - 84, 1996.

CASAS, J.; OCHOA, F. G. Sophorolipid production by Candida bombicola: medium composition and culture methods. Journal of Bioscience anf Bioengeneering, v. 88, p. 488494, 1999.

CASTIGLIONI, G. L.; BERTOLIN, T. E.; COSTA, J. A. V. Produção de biossurfactante por Aspergillus fumigatus utilizando resíduos agroindustriais como substrato. Química Nova, v. 32, n. 2, p. 292-295, 2009.

CHANDEL, A. K. et al. Multi-scale structural and chemical analysis of sugarcane bagasse in the process of sequential acid-base pretreatment and ethanol production by Scheffersomyces shehatae and Saccharomyces cerevisiae. Biotechnology for Biofuels, v. 7, n. 63, p. 1-17, 2014.

CHANDER, C. R. S. et al. Production and characterization of biosurfactant from Bacillus subtilis MTCC441 and its evaluation to use as bioemulsifier for food bio - preservative. Advances in Applied Science Research, v. 3, n. 3, p. 1837-1831, 2012.

CHEBBI, A. et al. Rhamnolipids from Pseudomonas aeruginosa strain W10; as antibiofilm/antibiofouling products for metal protection. Journal of Basic Microbiology, v. 57, n. 5, p. 364-375, 2017.

CHEN, C. Y.; BAKER, S. C.; DARTON, R. C. The application of a high throughput analysis method for the screening of potential biosurfactants from natural sources. Journal of Microbiological Mathods, v. 70, p. 503-510, 2007.

CHI, Z. et al. Bioproducts from Aureobasidium pullulans, a biotechnologically important yeast. Applied Microbiology and Biotechnology, v. 82, p.793-804, 2009.

CHRISTOFI, N.; IVSHNA, I. B. Microbial surfactants and their use in field studies of soil remediation. Journal of Applied Microbiology, v.93, p.915-929, 2002.

CIRIGLIANO, M. C.; CARMAN, G. M., Isolation of a bioemulsifier from Candida lipolytica. Applied and Environ Microbiology, v. 48, p. 747-750, 1984.

COIMBRA, C. D. et al. Studies of the cell surface properties of Candida species and relation to the production of biosurfactants for environmental applications. Current Microbiology, v. 58, p. 245-251, 2009.

COMPANHIA NACIONAL DE ABASTECIMENTO. Acompanhamento da safra brasileira: cana-de-açúcar, primeiro levantamento, abril/2017. Brasília. Conab. Disponível: < http://www.conab.gov.br/OlalaCMS/uploads/arquivos/17_04_20_14_04_31_boletim_cana_p ortugues_-_10_lev___17-18.pdf >. Acesso em: 08 maio 2017.

COOPER, D. G., GOLDENBERG, B. G. Surface active agents from two Bacillus species. Applied Environmental Microbiology, v. 53, p. 224-229, 1987. 
COOPER, D. G. et al. Surface activities of Mycobacterium and Pseudomonas. Journal of Fermentation Technology, v. 59, p. 97-101, 1989.

COOPER, D. G. et al. Enhanced production of surfactin from Bacillus subtilis by continuous product removal and metal cation additions. Applied and Environmental Microbiology, v. 42, p. 408-412, 1981.

COOPER, D.G.; PADDOCK, D. A. Torulopsis petrophilum and surface activity. Applied Environmental Microbiology, v. 46, p. 1426-1429, 1983.

COOPER, D. G.; PADDOCK, D. A. Production of a biosurfactant from Torulopisis bombicola. Applied and Environmental Microbiology, v. 47, p. 173-176, 1984.

COSTA, S. G. V. A. O. et al. Production of Pseudomonas aeruginosa LBI rhamnolipids following growth on Brazilian native oils. Process Biochemistry, v. 41, p. 483-488, 2006.

COUTO, S. R.; SANROMAN, M. A. Application of solid-state fermentation to food industry, a review. Journal of Food Enginnering, v. 76, n. 3, p. 291- 302, 2006.

DAS, K.; MUKHERJEE, A. K. Comparison of lipopeptide biosurfactants production by Bacillus subtilis strains in submerged and solid state fermentation systems using a cheap carbon source: Some industrial applications of biosurfactants Process Biochemistry, v. 42, p. 11911199, 2007.

DE, S. et al. A review on natural surfactants. RSC Advances, v. 5, p. 65757-65767, 2015.

DELBEKE, E. I. P.; ROMAN, B. I. MARIN, G. B.; VAN GEEM, M. K.; STEVENS, C. V. A new class of antimicrobial biosurfactant: quaternary ammonium sophorolipids. Green Chemistry, v.19, n. 6, p. 3373-3377, 2015.

DESAI, J. D.; DESAI, A. J. Production of biosurfactant, In: Kosaric N. editor, Biosurfactants: production, propeties, applications. New York: Marcel Dekker, p. 78 - 88. 1993.

DESAI, J. D.; BANAT, I. M. Microbial productionof surfactants and their commercial potential. Microbioly and Molecular Biology Reviews, v. 61, n. 1, p. 47-64, 1997.

DESHPAND, M. S.; RALE, V. B.; LYNCH, J. M. Aureobasidium pullulans in applied microbiology: A status report. Enzyme and Microbial Technology, v. 14, p. 5514-527, 1992.

DECESARO, A.; RIGON, M. R.; THOMÉ, A.; COLLA, L. M. Produção de biossurfactantes por microrganismos isolados de solo contaminado com óleo diesel. Química Nova, v. 36, n. 7, p. $947-954,2013$.

DIAB, A.; DIN, S. G. E. Application of the biosurfactants produced by Bacillus spp. (SH 20 and SH 26) and Pseudomonas aeruginosa SH 29 isolated from the rhizosphere soil of an Egyptian salt marsh plant for the cleaning of oil - contaminataed vessels and enhancing the biodegradation of oily sludge. African Journal of Enviromental Science and Technology, v. 7, n. 7, p. 671-679, 2013. 
DOSHIDA, J.; HASEGAWA, H.; ONUKI, H.; SHIMIDZU, N. Exophilin A, a new antibiotic from a marine micro-organismo Exophiala pisciphila. The Journal of Antibiotics, v. 49, n. 11, p. 1105-1109, 1996.

DUBOIS, M. et al. Colorimeric method of determination of sugars and related substances. Analytical Chemistry, v. 28, p. 350-356, 1956.

DUBEY, K. V.; JUWAKAR, A. A.; SINGH, S. K. Adsorption-desorption process using wood-based activated carbon for recovery of biosurfactant from fermented distillery wastewater. Biotechnology Process, v. 21, n. 3, p. 860-867, 2005.

DUNUOY, P. L. An interfacial tensiometer for universal use. The Journal of General Physiology, v. 5, p. 625-633, 1925.

DURAND, A. Bioreactor designs for solid-state fermentation. Biochemical Engineering Journal, v. 13, p.113-125, 2003.

ELSHIKH, M. et al. Rhamnolipids from non-pathogenic Burkholderia thailandensis E264: Physicochemical characterization, antimicrobial and antibiofilm efficacy against oral hygiene related pathogens. New Biotechnology, v. 36, p.26-36, 2017.

ESCALANTE, J. et al. Production of arabitol from glucose by Hansenula polymorpha. Journal of Fermentation and Bioengineering, v. 70, n. 4, p. 228-231, 1990.

FERNANDEZ, D. E. R. et al. The behavior of kinetic parameters in production of pectinase and xylanase by solid-state fermentation. Bioresource Technology, v. 102, n. 22, p. 1065710662, 2011.

FERREIRA, D. F. Sisvar: a computer statistical analysis system. Ciência e Agrotecnologia (UFLA), v. 35, n.6, p. 1039-1042, 2011.

FONTES, G. C.; AMARAL, P. F. F.; COELHO, M. A. Z. Produção de biossurfactante por levedura. Química Nova, v. 31, n. 8, p. 2092-2099, 2008.

FONTES, G. C. et al. Factorial Design to Optimize Biosurfactant Production by Yarrowia lipolytica. Journal of Biomedicine and Biotechnology, v. 2010, p. 1-8, 2010.

FONTES, G. C. et al. Renewable resources for biosurfactant production by Yarrowia lipolytica. Brazilian Journal of Chemical Engineering, v. 29, n. 3, p. 483-494, 2012.

FRAKUDDIN, M. Biosurfactant: production and application. Jounal of Petroleum \& Environmental Biotechnology, v. 3, n. 4, p.1-5, 2012.

FRANCY, D. S. et al. Emulsification of hydrocarbon by surface bacteria. Journal of Industrial Microbiology, n. 8. p. 237-246, 1991.

GARAY, L. A. et al. Discovery of synthesis and secretion of polyol esters of fatty acids by four basidiomycetous yeast species in the order Sporidiobolales. Journal of Industrial Microbiology \& Biotechnology, v. 44, n. 6, p. 923-936, 2017. 
GAUR. R. et al. Aureobasidium pullulans, an economically important polymorphic yeast with special reference to pullulan. African Journal of Biotechnology, v. 47, p.7989-7997, 2010.

GHOSE, T. K. Measurement of cellulase activities. Pure and Applied Chemistry, v. 59, n. 2, p. 257-268, 1987.

GIBBS, P. A.; SEVIOUR, R. J.; SCHMID, F. Growthof filamentous fungi in submergedculture: problems andpossible solutions. Critical Revews in Biotechnology, v. 20, n. 1, p. 17-48, 2000.

GLOBAL MARKET INSIGHTS. Biosurfactants Market Size, Share, Price Trends 2016 2023, 100 p., 2016. Disponível em: https://www.gminsights.com/industryanalysis/biosurfactants-market-report. Acesso em: 26 maio 2017.

GOUVEIA, E. R. et al. Validação de metodologia para a caracterização química de bagaço de cana-de-açúcar. Química Nova, v. 32, n. 6, p. 1500-1503, 2009.

GRIFFIN, W. C. Classification of surface-active agents by "HLB". Journal of the Society of Cosmetic Chemists, v. 5, n. 1, p. 311, 1949.

GRIFFIN, W. C. Calculation of HBLvalues of non-ionic surfactants. Journal of the Society of Cosmetic Chemists, v. 5, n. 1, p.249-256, 1954.

GRAÇA, M. M. C. S. Salt stress response of the extremely halotolerant yeast Candida halophila (syn versatilis) CBS 4019: biochemical and physiological studies. 2004. Tese (Doutorado em Biologia) - Universidade do Moinho, Portugal, 2004.

GUSMÃO, C.; RUFINO, R.; SARUBBO, L. Laboratory production and characterization of a new biosurfactant from Candida glabrata UCP1002 cultivated in vegetable fat waste applied to the removal of hydrophobic contaminant. World Journal of Microbiology and Biotechnology, v. 26, n. 9, p.1683-1692, 2010.

HIBBETT, D. S., BINDER, M., BISCHOFF, J. F. A higher-level phylogenetic classification of the fungi. Micological Research, v. 111, n. 5, p. 509-547, 2007.

HISATSUKA, K. et al. Formation of rhamnolipid by Pseudomonas aeruginosa: its function in hydrocarbon fermentations. Agricultural and Biological Chemistry, v. 35, n. 5, p. 686-692, 1971.

HÖLKER, U.; LENZ, J. Solid-state fermentation - are there any biotechnological advantages? Current Opinion in Microbiology, v. 8, n. 3, p. 301-306, 2005.

HOLMBERG, K. et al. Surfactants and polumers in aqueous solutions. 2 ed. New York: Jonh Wiley \& Sons Ltda. (Ed.), 2002. p. 451-471

HOMMEL, R. K. et al. Production of water-soluble surface-active exolipids by Torulopsis apicola. Applied Microbiology and Biotechnology, v. 26, n. 3, p. 199-205, 1987.

HOMMEL, R. K.; WEBER, L.; WEISS, A. Production of sophorose lipid by Candida (torulopsis) apícola grown on glucose. Journal of Biotechnology, v. 33, n. 2, p. 147-55, 1994. 
HOSSEINPOUR, M. N. et al. Lipase production in solid state fermentation using Aspergillus niger: Response surface methodology. International Journal of Engineering, Transactions B: Applications, v. 25, n. 3, p. 151-159, 2012.

HYUNG-PHIL, S. et al. Continuous production of pullulan by Aureobasidium pullulans HP2001 with feeding of high concentration of sucrose. Journal of Microbiology and Biotechnology, v. 16, n. 3, p. 374-380, 2006.

ISODA, H.; NAKAHARA, T. Antiproliferative effect of polyol lipids, 3,5-dihydroxydecanoyl and 5-hydroxy-2-decanoyl esters of arabitol and mannitol on lung cancer cell line A549. Journal of Fermentation and Bioengineering, v. 84, p. 403-406, 1997.

IZARD, J.; LIMBERGER, R. J. Rapid screening for quantitation of bacterial cell lipids from whole cells. Journal of Microbiological Methods, v. 55, n. 2, p. 411-418, 2003.

JADHAV, D. M.; GAWAI, D. U. Isolation and characterization of Aureobasidium pullulans (De Bary) a phylloplane yeast of sandal and guava. Bionano Frontier, v. 6, n. 1, p. 57-59, 2013.

JARVIS, F. G.; JOHNSON, M. J. A glycolipide produced by Pseudomonas aeruginosa. Journal of the American Chemical Society, v. 71, n. 12, p. 4124-4126, 1949.

JAVAHERI, M. et al. Anaerobic production of a biosurfactant by Bacillus licheniformis JF-2. Applied and Environmental Microbiology, v. 50, n. 3, p. 698-700, 1985.

KAPPELI, O.; FINNERTY, W. R. Partition of alkane by an extracellular vesicle derived from hexadecane-grown Acinetobacter. Journal of Bacteriology, v. 140, n. 2, p. 707-712, 1979.

KAPPELI, O. et al. Structure of cell surface of the yeast Candida tropicalis and its relation to hydrocarbon tranport. Archives of Microbiology. v. 138, p. 279-282, 1984.

KIM, J. S.; LEE, I. K.; YUN, B. S. A novel biosurfactant produced by Aureobasidium pullulans L3-GPY from a tiger lily wild flower, Lilium lancifolium Thunb. PLoS One , v.10, n. 4, p. 1$12,2015$.

KITAMOTO, D. et al. Surface active properties and antimicrobial activities of mannosylerythritol lipids as biosurfactants produced by Candida antarctica. Journal of Biotechnology, v. 29, n. 1-2, p. 91-96, 1993.

KITAMOTO, D. et al. Microbial conversion of n-alkanes into glycolipid biosurfactants, mannosylerythritol lipids, by Pseudozyma (Candida antarctica). Biotechnology Letters, v. 23, n. 20, p. 1709-1714, 2001.

KOCH, A. K. et al. Genetic construction of lactose-utilizing strains of P. aeruginosa and their application in biosurfactant production. Nature Biotechnology, v. 6, p. 1335-1339, 1988.

KOSARIC, N. Biosurfactants for soil bioremediation. Food Technology and Biotechnology, v. 39, n. 4, p. 295-304, 2001. 
KULAKOVSKAYA, E.; KULAKOVSKAYA, T. Extracellular glycolipids of yeasts: biodiversity, biochemistry, and prospects. Oxford: Elsevier, p.10-15, 2013.

KUROSAWA, T. et al. Extracellular Accumulation of the Polyol Lipids, 3,5Dihydroxydecanoyl and 5-Hydroxy-2-decenoyl Esters of Arabitol and Mannitol, by Aureobasidium sp. Bioscience, Biotechnology and Biochemistry, v. 58, n. 11, p. 2057-2060, 1994.

KRIEGER, N; CAMILIOS NETO, D; MITCHELL D. Production of microbial biosurfactants by solid-state cultivation. In: RAMKRISHNA, S. (Org.). Biosurfactants. New York: Springer Science+Business media, LCC, Landes Bioscience, 2010. v. 672, p. 203-209.

KRONBERG, B.; HOLMBERG, K.; LINDMAN, B. Environmental and health aspects of surfactants. In: Surface chemistry of surfactants and polymers. Chichester, UK: John Wiley \& Sons, 2014. p. 49-64.

LEATHERS, T. D.; PRICE, N. P. J.; BISCHOFF, K. M.; MANITCHOTPISIT, P.; SKORY, C. D. Production of novel types of antibacterial liamocins by diverse strains of Aureobasidium pullulans grown on different cuture media. Biotechnology Letters, v. 37, n. 10. p. 2075-2081, 2015.

LEE, B. S.; KIM, E. K. Lipopeptide production from Bacillus sp. GB16 using a novel oxygenation method. Enzyme and Microbial Technology, v. 35, n. 6-5, p. 639-647, 2004.

LEITES, R. S. R. et al. Production of hemicellulolytic enzymes from Aureobasidium pullulans on solid state fermentation. Applied Biochemistry and Biotechnology, v. 136, n. 140, p. 281288, 2007.

LEWIS, D. H.; SMITH, D. C. Sugar alcohols (polyols) in fungi and greenplants.Iistribution, physiology and metabolism. The New Phytologist, v. 66, n. 2, p. 143-184, 1967.

LI, Y. et al. Taxonomy of Aureobasidium spp. and biosynthesis and regulation of their extracellular polymers. Critical Reviews in Microbiology, v. 41, n. 2, p. 228-237, 2015.

LIANG, X. et al. Anaerobic lipopeptide biosurfactant production by an engineered bacterial strain for in situ microbial enhanced oil recovery. RSC Advances, v. 7, n. 33, p. 20667-20676, 2017.

LIMA, A.L.; ALEGRE, R.M. Evaluation of emulsifier stability of biosurfactant produced by Saccharomyces lipolytica CCT-0913. Brazilian Archives of Biology and Technology, v. 52, n. 2, p.285-290, 2009.

LIN, S. C. Biosurfactants: recent advances. Journal Chemistry Tecnology and Biotechnology, v. 66, n. 2, p. 109-120, 1996.

LIN, S. C.; JIANG, H. J. Recovery and purification of the lipopeptide biosurfactant of Bacillus subtilis by ultrafiltration. Biotechnology Techniques, v. 11, n. 6, p. 413-416, 1997.

LIU, Y.; KOH, C. M. J.; JI, L. Bioconversion of crude glycerol to glycolipids in Ustilago maydis. Bioresource Technology, v.102, n. 4, p.3927-3933, 2011. 
LIU, Y. L. et al. Heavy oils, principally long-chain $n$-alkanes secreted by Aureobasidium pullulans var. melanogenum strain P5 isolated from mangrove system. Journal of Industrial Microbiology and Biotechnology. v.41, n. 9, p. 1329-1337, 2014.

LOTFABAD, T. B.; EBADIPOUR, N.; AZAD, R. R. Evaluation of a recycling bioreactor for biosurfactant production by Pseudomonas aeruginosa MR01 using soybean oil waste. Chemical Technology and Biotechnology, v. 91, n. 5, p.1368-1377, 2015.

LUNA, J. M. Otimização, caracterização e aplicações tecnológicas do biossurfactante de baixo custo Lunasan produzido por Candida spheaerica UCP 0995. 2010. Tese (Doutorado em Ciências Biológicas) - Universidade Federal de Pernambuco, Recife, PE, 2010.

LUNA, J. M.; SARUBBO, L. CAMPOS-TAKAKI, G. M. A new biosurfactant produced by Candida glabrata UCP 1002: Characteristics of Stability and Application in Oil Recovery. Brazilian Archives of Biology and Technology, v. 52, n. 4, p. 85-793, 2009.

MACDONALD, C. R.; COOPER D. G.; ZAJIC, Z. E.. Surface-active lipids from Nocardia erythropolis grown on hydrocarbons. Applied Environmental Microbiology. v. 41, n. 1, p. 117-123, 1981.

MADDIKERI, G. L.; GOGATE, P. R.; PADIT, A. B. Improved synthesis of sophorolipids from waste cooking oil using fed batch approach in the presence of ultrasound. Chemical Engeneering Journal, v. 263, n. 1, p. 479-487, 2015.

MADIGAN, M. T. et al. Brock Biology of Microorganisms. 14 ed. San Francisco, CA, USA: Benjamin Cummings, 2014. ISBN-10: 0321897390; ISBN-13: 978-0321897398.

MAKKAR, R.S.; CAMEOTRA. S.S. An update on the use of unconventional substrates for biosurfactant production and their new applications. Applied Microbiology Biotechnology, v. 58, n. 4, p. 428-434, 2002.

MANSO PAJARRON, A. et al. Structure identification of natural rhamnolipid mixtures by fast atom bombardment tandem mass spectrometry. Glycoconjugate Journal, v. 10, n. 3, p. 219226, 1993.

MANITCHOTPISIT, P. et al. Heavy oils produced by Aureobasidium pullulans. Biotechnology Letters, v. 33, n. 6, p. 1151-1157, 2011.

MANITCHOTPISIT, P. et al. Poly( $\beta$-L-malic acid) production by diverse phylogenetic clades of Aureobasidium pullulans. Journal of Industrial Microbiology \& Biotechnology, v. 39, n. 1, p. 125-132, 2012.

MANITCHOTPISIT, P. et al. Aureobasidium pullulans as a source of liamocins (heavy oils) with anticancer activity. World Journal of Microbiology and Biotechnology, v.30, n. 8, p. 2199-2204, 2014.

MARCHANT, R.; BANAT, I. M. Microbial biosurfactants: challenges and opportunities for future exploitation. Trends in Biotechnology, v. 30, n. 11, p. 558-565, 2012. 
MARKETS AND MARKETS. Surfactants Market by Type (Anionic, Non-Ionic, Cationic, and Amphoteric), Substrate (Synthetic, and Bio-based), Application (Detergents, Personal Care, Textile, Elastomers \& Plastics, Crop Protection, Food \& Beverage) - Global Forecast to 2021. Disponível em: http://www.marketsandmarkets.com/PressReleases/surfactants.asp. Acesso em: 08 mai 2017.

MARTINS, V.G.; KALIL, S.J.; COSTA, J.A.V. Co-produção de lipase e biossurfactante em estado sólido para utilização em biorremediação de óleos vegetais e hidrocarbonetos. Química Nova, v. 31, n. 8, p. 1942-1947, 2008.

MATSUYAMA, T.; SOGAWA, M.; YANO, I. Direct colony thin-layer chromatography and rapid characterization of Serratia marcescens mutants defective in production of wetting agents. Applied and Environmental Microbiology, v. 53, n. 5, p. 1186-1188, 1991.

MAZZUTI, M. A.; ZABOT, G.; BONI, G.; SKOVRONSKI, A.; OLIVEIRA, D.; DI LUCCIO, M.; RODRIGUES, M. I.; TREICHEL, H.MAUGERI, F. Kinetics of inulinase production by solid-state fermentation in a packed-bed bioreactor. Food Chemistry, v. 120, n. 1, p. 163-173, 2010 .

MEIRA, J. A. Produção de biosurfactantes por fermentação no estado sólido e desenvolvimento de aplicações para tratamento de solos contaminados por hidrocarbonetos. 94 f. 2007. Dissertação (Mestrado em Química Orgânica) - Universidade federal do Paraná, PR, 2007.

MERCADE, M. E.; MANRESA, M. A. The use of agroindustrial by-products for biosurfactant production. Journal of American Oil Chemist's Society, v. 71, n. 1, p. 61-64, 1994.

MILLER, G.L. Use of dinitrosalicylic acid reagent for determination of reducing sugar. Analytical Chemistry, v. 31, n. 3, p. 426-428, 1959.

MILNE, A. J. B.; ELLIOTT, J. A. W.; AMIRFAZLI, A. Contact angles of surfactant solutions on heterogeneous surfaces. Physical Chemistry Chemical Physics, v. 17, n. 8, p. 5574-5585, 2015.

MITCHEL, A. P. Dimorphism and virulence in Candida albicans. Current Opinion in Microbiology, v. 1, p. 687-692, 1998.

MITCHELL, A.D.; KRIEGER, N.; BEROVIC, M. Solid-state fermentation bioprocess. Berlin: Springer, 443 p., 2006.

MOISER, N. et al. Features of Promising Technologies for Pretreatment of Lignocellulosic Biomass. Bioresource Technology, v. 96, n. 6, p. 673-686, 2005.

MONTEIRO, A. S. et al. Indentification and characterization of bioemulsifier-producing yeasts isolated from effluents of dairy industry. Bioresource Technology, v. 101, p. 5186-5193, 2010.

MORIKAWA, M.; HIRATA, Y.; IMANAKA, T. A study on the structure-function relationship of lipopeptide biosurfactants. Biochimica et Biophysica Acta (BBA) - Molecular and Cell Biology of Lipids, v. 1488, n. 15, p. 211-218, 2000. 
MORIKAWA, M.; ITO, M.; IMANAKA, T. Isolation of a new surfactin producer Bacillus pumilus A-1, and cloning and nucleotide sequence of the regulator gene, psf-1. Journal of Fermentation and Bioengeneering, v. 47, n. 5, p. 255-261, 1992.

MORITA, T. et al. Discovery of Pseudozyma rugulosa NBRC 10877 as a novel producer of the glycolipid biosurfactants, mannosylerythritol lipids, based on rDNA sequence. Applied Microbiology and Biotechnology, v. 73, n. 305, p. 305-313, 2006.

MORITA, T. et al. Microbial conversion of glycerol into glycolipid biosurfactants, mannosylerythritol lipids, by a basidiomycete yeast, Pseudozyma antarctica JCM $10317^{\mathrm{T}}$. Journal of Bioscience and Bioengineering, v. 123, n. 6, p. 659-770, 2007.

MORRISON, I. D.; ROSS, S. Emulsions. In: Colloidal dispersions - suspensions, emulsions, and foams. New York: John Wiley \& Sons Ltd. (Ed.), p. 420-455, 2002.

MOUBARIKA, A. et al. Isolation and characterization of lignin from Moroccan sugar cane bagasse: Production of lignin-phenol-formaldehyde wood adhesive. Industrial Crops and Products, v. 45, p.296-302, 2013.

MOUTTA, R. O.; FERREIRA, V. S.; BON, E. P. Enzymatic hydrolysis of sugarcane bagasse and straw mixtures pretreated with diluted acid. Biocatalysis and Biotransformation, v. 32, n.1, p. 93-100, 2014.

MUKHERJEE, S.; DAS, P.; SEN, R. Towards commercial production of microbial surfactants. Trends in Biotechnology, v. 24, n. 11, p. 509-515, 2006.

MUKERJEE, P.; MYSELS, K. J. Critical micelle concentrations of aqueous surfactant systems. Washington: National Bureau of Standards, 1971. 222 p.

MULLIGAN, C. N.; COOPER, D. G.; NEUFELD, R. J. Selection of microbes producing biosurfactants in media without hydrocarbons. Journal of Fermentation Technology, v. 62, n. 4 , p. $311-314,1984$.

MULLIGAN, C. N. Environmental application for biosurfactants. Environmental Pollution, v. 133, n. 2, p. 183-198, 2005.

MULLIGAN, C. N. Recent advances in the environmental applications of biosurfactants. Current Opinion in Colloid \& Interface Science, v. 14, n. 5, p. 372-378, 2009.

MULLIGAN, C. N.; GIBBS, B. F., Factors influencing the economics of biosurfactants. In: KOSARIC, N. (ed.), Biosurfactants: production, properties, applications. New York: Marcel Dekker, 1993, v. 10, p. 329-371.

NAGATA, N.; NAKAHARA, T.; TABUCHI, T. Fermentative production of poly(b-L malic acid), a polyelectrolytic biopolyester, by Aureobasidium sp. Bioscience, Biotechnology and Biochemistry, n. 57, n. 4, p. 638-642, 1993.

NEU, T. R.; PORALLA, K. Emulsifying agent from bacteria isolated during screening for cells with hydrophobic surfaces. Applied Microbiology and Biotechnology, v. 32, n. 5, p. 521$525,1990$. 
NITSCHKE, M.; PASTORE, G. M. Biossurfactantes: propriedades e aplicações. Química Nova, v. 26, n. 5, p. 772-776, 2002.

NITSCHKE, M.; PASTORE, G. M. Production and properties of a surfactant obtained from Bacillus subtilis grown on cassava wastewater. Bioresource Technology, v. 97, n. 2, p.336-341, 2006.

NOGUEIRA, E. B. S.; CAVALCANTI, M. A. C. Cellulolytic fungi isolated from processed oats. Revista de Microbiologia, v. 27, n. 1, p. 7-9, 1996.

OHNO, A; ANO, T.; SHODA, M. Production of a lipopeptide antibiotic, surfactin, by recombinant Bacillus subtilis in solid state fermentation. Biotechnology and Bioengineering, v. 47, n. 2, p, 209-214, 1995

OLIVEIRA, A. G. et al. Microemulsões: estrutura e aplicações como sistema de liberação de fármacos. Química Nova, v. 27, n. 1, P. 131-138, 2004.

OLIVEIRA, D. W. et al. Kinetic study of biosurfactant production by Bacillus subtilis LAMI005 grown in clarified cashew apple juice. Colloids and Surfaces B: Biointerfaces, v. 101, n. 1, p. 34-43, 2013.

OURA, E. Effect of aeration intensity on the biochemical composition of baker's yeast: factors affecting the type of metabolism. Biotechnology and Bioengineering, v. 16, n. 9, p.1197-1212, 1974.

PANDEY, A. Solid-state fermentation. Biochemical Engineering Journal. v. 13, n. 2-3, p. 81-84, 2003.

PATIL, J. R.; CHOPADE, B. A. Studies on bioemulsifier production by Acinetobacter strains isolated from health human skin. Journal of Applied Microbiology, v. 91, n. 2, p. 290-298, 2001.

PEERSON, A.; MOLIN, G. Capacity of biosurfactants production of environmental Pseudomonas and Vibrionaceae growing on carbohydrates. Applied Microbiology Biotechnology, v. 36, n. 5, p. 439-442, 1987.

PEIXOTO, R. M. Bioprospecção de micro-organismos do gênero Pseudomonas produtores de biossurfactantes. 2008. 98 f. Dissertação (Mestrado em Ciências Biológcas) - Instituto de Ciências Biomédicas, Universidade de São Paulo, São Paulo, SP, 2008.

PEREIRA, J. F. B. et al. Optimization and characterization of biosurfactant production by Bacillus subtilis isolates towards microbial enhanced oil recovery applications. Fuel, v. 111, p. 259-268, 2013.

PHETRONG, K.; H-KITTIKUN, A.; MANEERAT, S. Production and characterization of bioemulsifier from a marine bacterium, Acinetobacter calcoaceticus subsp. anitratus SM7. Songklanakarin Journal of Science and Technology, v. 30, n. 3, p. 297-305, 2008. 
PIRÔLLO, M. P. S. Estudo da produção de biossurfactantes utilizando hidrocarbonetos. 2006. 61 f. Dissertação (Mestrado em Ciências Biológicas) - Instituto de Biociência, Universidade Estadual Paulista, Rio Claro, SP, 2006.

PLAZA, G. A.; ZJAWIONY, I.; BANAT, I. M. Use of different methods for detection of thermophilic biosurfactant-producing bacteria from hydrocarbon-contaminated and bioremediated soils. Journal of Petroleum Science and Engineering, v. 50, n. 1, p. 71-77, 2006.

PLEISSNER, D. et al. Fermentative lactic acid production from coffee pulp hydrolysate using Bacillus coagulans at laboratory and pilot scales. Bioresource Technology, v. 218, p. 167-173, 2016.

POINTING, S. B. Qualitative methods for the determination of lignocellulolytic enzyme production by tropical fungi. Fungal Diversity, v. 2, p. 17-33, 1999.

PORNSUNTHORNTAWEE, O. et al. Structural and physicochemical characterization of crude biosurfactant produced by Pseudomonas aeruginosa SP4 isolated from petroleumcontaminated soil. Bioresource Technology, v. 99, n. 6, p. 1589-1595, 2008.

PRICE, N. P. J. et al. Structural characterization of novel extracellular liamocins (mannitol oils) produced by Aureobasidium pullulans strain NRRL 50380. Carbohydrate Research, v. 370, p. 24-32, 2013.

PRIETO, L. M. et al. The production of rhamnolipid by a Pseudomonas aeruginosa strain isolated from a southern coastal zone in Brazil. Chemosphere, v, 71, n. 9, p. 1781-1785, 2008.

PRUTHI, V.; CAMEOTRA, S. S. Production and properties of a biosurfactant synthesized by Arthrobacter protophormiae protophormiae - an Antarctic strain. World Journal of Microbiology and Biotechnology, v. 13, n. 1, p.137-139, Jan. 1997.

PUTRI, M.; HERTADI, R. Effect of glycerol as carbon source for biosurfactant production by halophilic bacteria Pseudomonas stutzeri BK-AB12. Procedia Chemistry, v. 16, p. 321-327, 2015.

RAPP, P. et al. Formation, isolation and characterization of trehalose dimycolates from Rhodococcus erythropolis grown on n-alkanes. Journal of General Microbiology, v. 115, p. 491-503, 1979.

RATLEDGE, C. Fatty acid biosynthesis in microorganisms being used for single cell oil production. Biochimie, v. 86, n. 11, p. 807-15, 2004.

RAY, R. C.; MOORTHY, S. N. Exopolysaccharide production from cassava starch residue by Aureobasidium pullulans strain MTCC 1991. Journal of Science and Industrial Research, v. 66, p. 252-255, 2007.

REGULY, J. C. Biotecnologia dos processos fermentativos, Pelotas: Editora e Gráfica universitária, 2000. v. 3, 219. 
REZENDE, C., A. et al. Chemical and morphological characterization of sugarcane bagasse submitted to a delignification process for enhanced enzymatic digestibility. Biotechnology for Biofuels, v. 4, n. 54, p. 1-18, 2011.

RINALDI, R. et al. Síntese de biodiesel: uma proposta contextualizada de experimento para laboratório de química geral. Química Nova, v. 30, n. 5, p. 1374-1380, 2007.

ROCHA, G. J. et al. Dilute mixed-acid pretreatment of sugarcane bagasse for ethanol production. Biomass and Bioenergy, v. 35, n. 1, p. 663-670, 2010.

RODRIGUES, L. et al. Kinetic study of fermentative biosurfactant production byLactobacillus strains. Biochemical Engineering Journal, v. 28, n. 2, p. 109-116, 2006.

ROMANELLI, M. F. Avaliação da toxicidade aguda e crônica dos surfactantes DSS e LAS submetidos à irradiação com feixe de elétrons. 2004. 143 f. Dissertação (Mestrado em Ciências) - Instituto de Pesquisas Energéticas e Nucleares, Universidade de São Paulo, São Paulo, SP, 2008.

RON, E.Z.; ROSENBERG, E. Natural roles of biosurfactants. Environmental Microbiology, v.3, n. 4, p. 229-236, 2001.

ROSA, M. F. et al. Valorização de resíduos da agroindústria. In: SIMPÓSIO INTERNACIONAL SOBRE GERENCIAMENTO DE RESÍDUOS AGROPECUÁRIOS E AGROINDUSTRIAIS 2., 2011. -II SIGERA, Foz do Iguaçu, PR.

ROSEN, M. J.; KUNJAPPU, J. T. Surfactants and Interfacial Phenomena. 4 th, New Jersey: John Wiley \& Sons, 2012. 592 p.

ROSENBERG, E. et al. Production of biodispersan by Acinetobacter calcoaceticus A2. Applied and Environmental Microbiology, v. 54, n. 2, p. 317-322, 1988.

ROSENBERG, M.; GUTNICK, D. L.; ROSENBERG, E. Adherence of bacteria to hydrocarbons: a simple method for measuring hydrophobicity. FEMS Microbiology Letters, v. 9, n. 1, p. 29-33, 1980.

RUFINO, R. D. et al. Antimicrobial and anti-adhesive potential of a biosurfactant Rufisan produced by Candida lipolytica UCP0988. Colloids and Surfaces B: Biointerfaces, n. 84, n. 1, p. 1-5, 2011.

SAHARAN, B.S.; SAHU, R. K.; SAHRMA, D. A review on biosurfactants: fermentation, current developments and perspectives. Genetic Engineering and Biotechnology Journal, v. 29, p. 1-14, 2012.

SANCHEZ, L. B. R. et al. Fungal lipase production by solid-state fermentation. Journal of Bioprocessing and Biotechniques, v. 5, n. 2, p. 1-9, 2015.

SARAVANAKUMARI, P.; MANI, K. Structural characterization of a novel xylolipid biosurfactant from Lactococcus lactis and analysis of antibacterial activity against multi-drug resistant pathogens. Bioresource Technology, v. 101, n. 22, p. 8851-8854, 2010. 
SANTOS, D. K. et al. Optimization of cultural conditions for biosurfactant production from Candida lipolytica. Biocatalysis and Agricultural Biotechnology, v. 3, n. 3, p. 48-57, 2014.

SANTOS, D. K. et al. Biosurfactants: Multifuntional Biomolecules of the 21 st Century. International Journal of Molecular Science, v. 17, n. 3, p. 1-31, 2016.

SANTOS, D. K. F. et al. Biosurfactant production from Candida lipolytica in bioreactor and evaluation of its toxicity for application as a bioremediation agente. Process Biochemistry. v. 54, p. 20-27, 2017.

SATPUTE, S. K. et al. Methods for investigating biosurfactants and bioemulsifiers: a review. Critical reviews in Biotechnology. v. 30, n. 2, p. 127-144, 2010.

SATPUTE, S. K. et al. Assesment of different screening methods for selecting biosurfactant producing marine bacteria. Indian Journal of Marine Sciences, v. 37, n. 3, p. 243-250, 2008.

SCHMITT, T. M. Analysis of surfactants. New York: Marcel Dekker, 2001, v. 96, 645 p.

SCHUMANN, J.; HERTWECK, C. Advances in cloning, functional analysis and heterologous expression of fungal polyketide synthase genes. Journal of Biotechnology, v. 124, n. 4, p. 690703, 2006

SINGH, M.; DESAI, J. D. Hydrocarbon emulsification by Candida tropicalis and Debaryomyces polymorphus. Indian Journal of Experimental Biology, v. 27, n. 3, p. 224226, 1989.

SHEPPARD, J. D., MULLIGAN, C. N. The production of surfactin by Bacilus subtilis grown on peat hydrolysate. Applied Microbiology Biotechnology, v. 27, n. 2, p. 110-116, 1987.

SHENG, L.; TONG, Q.; MA, M. Why sucrose is the most suitable substrate for pullulan fermentationby Aureobasidium pullulans CGMCC1234? Enzyme and Microbial Technology, v. 92, p. 49-55. 2016.

SIEGMUND, I.; WAGNER, F. New method for detecting rhamnolipids excretedby Pseudomonas spp. during growth on mineral agar. Biotechnology Techniques, v. 5, n. 4, p. 265-268, 1991.

SILVA, J. P. A.; MUSSATO, S. I.; ROBERTO, I. C. The Influence of initial xylose concentration, agitation and aeration on ethanol production by Pichia stipites from rice straw hemicellulosic hydrolysate. Applied Biochemistry and Biotechnology, v. 162, n. 5, p. 1306$1315,2010$.

SILVA, S. S.; AFSCHAR, A. S. Production of xylitol from D-xyloseusing Candida tropicalis. Bioprocess and Biosystems Engeneering, v. 11, n. 4, p. 129-134, 1994.

SILVA, N. R. A. et al. Biosurfactant-and-bioemulsifier produced by a promising Cunninghamella echinulata isolated from caatinga soil in the northeast of Brazil. International Journal of Molecular Science, v. 15, n. 9, p. 15377-15395, 2014a. 
SILVA, R. C. F. S. et al. Applications of Biosurfactants in the Petroleum Industry and the Remediation of Oil Spills. International Journal of Molecular Science, v. 15, n. 7, p. 12523$12542,2014 b$.

SHEPHERD, R. et al. Novel bioemulsifiers from microrganisms for use in food. Journal of Biotechnology, v. 40, n. 3, p. 207-217, 1995.

SKINNER, C. E. The yeast-like fungi: Candida and Brettanomyces. Microbiology and Molecular Biology Reviews, v. 11, n. 4, p. 227-274, 1947.

SLUITER A. et al. Determination of structural carbohydrates and lignin in biomass. Laboratory Analytical Procedure (LAP). Disponível em: http://www.nrel.gov/docs/gen/fy13/42618.pdf. Data de revisão: agosto, 2012.

SMYTH, T. J. P. et al. Isolation and analysis of low molecular wheight microbial glycolipids. In: TIMMIS, K. N. (ed), Handbook of hydrocarbon and lipid microbiology, Berlin: Springer, 2010. p. 3705-3723.

SOCCOL, C. R.; VANDENBERGHE, L. P. S.; PANDEY, A. General aspects in citric acid production by submerged and solid-state fermentation. In: ENCYCLOPEDIA on bioresource technology. New York: Hawort Press, 2002.

SOUSA, M. et al. Screening of biosurfactant-producing Bacillus strains using glycerol from the biodiesel synthesis as main carbon source. Bioprocess and Biosystems Engineering, v. 35, n. 6, p. 897-906, 2012.

SOUZA, E. C.; VESSONI-PENNA, T.C.; OLIVEIRA, R. P. S. Biosurfactant - enhanced hydrocarbon biorremediation: an overview. International Biodeterioration \& Biodegradation, v. 89, p. 88-94, 2014.

SOUZA, K. S. T. et al. New glycolipid biosurfactants produced by the yeast strain Wickerhamomyces anomalus CCMA 0358. Colloids and Surfaces B: Biointerfaces, v. 154, p. 373-382, 2017.

STODOLA, F. H.; DEINEMA, M. H.; SPENCER, J. F. T. Extracellular lipids of yeasts. Bacteriological Reviews, v. 31, n. 3, p. 194-213, 1967.

SUGUMARAN, K. R.; JOTHI, P.; PONNUSAMI, V. Bioconversion of industrial solid waste - cassava bagasse for pullulan production in solid state fermentation. Carbohydrate polymers, v. 99, p. 22-30, 2014.

SUN, J. X. et al. Isolation and characterization of cellulose from sugarcane bagasse. Polymer Degradation and Stability, v. 84, n. 2, p. 331-339, 2004.

SUTHERLAND, L.W. Novel and stablished application of microbial polysaccharide. Trends in Boitechnology, v. 16, n. 1, p. 41-46, 1998.

SUZUKI, T. et al. The chemical structure of polymyxin E. The identities of polymyxin E1 with colistin A and polymyxin E2 with colistin B. Journal of Biological Chemistry, v. 57, p. 226$227,1965$. 
SYLDATK, C.; LANG, S.; WAGNER, F. Chemical and physical characterization of four interfacial-active rhamnolipids from Pseudomonas sp. DSM 2874 grown on n-alkanes. Zeitschrift für Naturforschung, v.40, n. 1-2, p. 51-60, 1985.

SYDATK, C.; WAGNER, F. Production of biosurfactants. In: KOSARIC, N.; CAIRNS, W. L.; GARY, N. C. C. Biosurfactants and Biotechnology. (Ed.) New York: Marcel Dekker, 1987. p. $89-120$

TECHAOEI, S. et al. Preliminary screening of biosurfactant producing microorganisms isolated from hot spring and garages in northern Thailand. KMITL Science and Technology Journal, v. 7, n. 1, p. 38-43, 2007.

THANIYAVARN, J. et al. Production of sophorolipid biosurfactant by Pichia anomala. Bioscience Biotechnology Biochemistry. v. 72, n. 8, p. 2061-206, 2008.

THANOMSUB, B. et al. Monoacylglycerols: glycolipid biosurfactants produced by a thermotolerant yeast, Candida ishiwadae. Journal of Applied Microbiology, v. 96, n. 3, p.588-592, 2004.

THAVASI, R. et al. Production and characterization of a glycolipid biosurfactant from Bacillus megaterium using economically cheaper sources. World Journal of Microbiology and Biotechnology, v. 24, n. 7, p. 917-925, 2008.

THAVASI, R.; SHARMA, S.; JAYALAKSHMI, S. Evaluation of screening methods for the isolation of biosurfactant producing marine bacteria. Journal of Petroleum \& Environmental Biotechnology, v.1, p. 1-6, 2011.

THOMAS, L.; LARROCHE, C.; PANDEY, A. Current developments in solid-state fementation. Biochemical Engeneering Journal, v. 81, p. 146-161, 2013.

TOREN, A. et al. The active component of the bioemulsifier alasan from Acinetobacter radioresistens KA53 is an OmpA-like protein. Journal of Bacteriology, v. 184, n. 1, p. 165170, 2002.

TREVAN, D. T. et al. Biotecnologia: princípios básicos. Zaragoza: Editorial Acribia S. A., 1990. $284 \mathrm{p}$.

VAN Der VEGT, W. et al. Assessment of bacterial biosurfactant production through axisymetric drop shape analysis by profile. Applied Microbiology and Biotechnology, v. 35, n. 6, p. 766-770, 1991.

VAZ Jr, S. As biorrefinarias como oportunidade de agregar valor à biomassa. Agroenergia. n. 4, p. 11-12, 2012.

VANDENBERGHE, L. P. S. et al. Solid-state fermentation for the synthesis of citric acid by Aspergillus niger. Bioresource Technology, v. 74, n. 2, p. 175-178, 2000. 
VAN-HAMME, J. D.; SINGH, A.; WARD, O. P. Physiological aspects part 1 in a series of papers devoted to surfactants in microbiology and biotechnology. Biotechnology Advances, c. 24, n. 6, p. 604-620, 2006.

VATSA, P. et al. Rhamnolipid biossurfactants as new players in animal and plan defense against microbes. International Journal of Molecular Science, v. 11, n. 12, p. 5095-5108, 2010 .

VECINO, X. et al. Optimization of extraction conditions and fatty acid characterization ofLactobacillus pentosus cell-bound biosurfactant/bioemulsifier. Journal of the Science of Food and Agriculture, v. 95, n. 2, p. 313-320, 2015.

VEENANADIG, N. K.; GOWTHAMAN, M. K.; KARANTH, N. G. K. Scale up studies for the production of biosurfactant in packed column bioreactor. Bioprocess Engineering, v. 22, n. 2, p. 95-99, 2000.

VIJAYAKUMAR, S.; SARAVANAN. V. Biosurfactants-types, sources and applications. Research Journal of Microbiology. v.10, n. 5, p. 181-192, 2015.

XUE, J. et al. Marine oil-degrading microorganisms and biodegradation process of petroleum hydrocarbon in marine environments: a review. Current Microbiology, v. 71, n. 2, p. 220 $228,2015$.

WEBER, L. et al. Oxigenation of hexadecane in the biosynthesis of cyclic g;ycolipids in Torulopsis apicola. Biocatalysis and Biotransformation, v. 5, n. 4, p. 267-272, 1992.

WEI, P. et al. Production of poly(malic acid) from sugarcane juice in fermentation by Aureobasidium pullulans: Kinetics and process economics. Bioreource Technology, v. 224, p. 581-589, 2017.

WILLENBACHER, J. et al. Foam-free production of Surfactin via anaerobic fermentation of Bacillus subtilis DSM 10 ${ }^{\mathrm{T}}$. AMB Express, v. 5, n. 21, p. 1-9, 2015.

WHITAKER, J. R.; VORANGEN, A. G. J.; WONG, D. W. S. Handbook of food enzimology. New York: Marcel Dekker, 2002. 1128 p.

WORLD HEALTH ORGANIZATION. Weekly Epidemiological Records. v. 40, 340 p., 1994.

YABUTA, T.; SUMIKI, Y.; TAMARI, K. Chemical constituents of inekoji. VIII. Arabityl margarate. Journal of the Agricultural Chemical Society of Japan. v. 17, p. 307-310, 1941.

YEH, M.S.; WEI, T.H.; CHANG, J.S. Bioreactor design for enhanced carrierassisted surfactin production with Bacillus subtilis. Process Biochemistry, v. 41, n. 8, p. 1799-1805, 2006.

YOUSSEF, N. H. et al. Comparasion of methods to detect biosurfactant production by diverse microorganism. Journal of Microbiological Methods, v. 56, n. 3, p. 339-347, 2004.

ZALAR, P. et al. Redefinition of Aureobasidium pullulans and its varieties. Studies in Mycology, v. 61, p. 21-38, 2008. 
ZHENG, Z. et al. Production of 3-hydroxydecanoic acid by recombinant Escherichia coli HB101 harboring phaG gene. Antonie van Leeuwenhoek, v. 85, n. 2, p. 93-101, 2004.

ZINJARDE, S. S.; PANT, A. Emulsifier from a tropical marine yeast, Yarrowia lipolytica NCIM 3589. Journal of Basic Microbiology, v. 42, n. 1, p. 67-73, 2002.

ZOSIM, Z.; GUTNICK, D. L.; ROSENBERG. E. Properties of hydrocarbon-in-water emulsions stabilized by Acinetobacter RAG-1 emulsan. Biotechnology and Bioengeering, v. 24, n. 2, p. 281-292, 1982.

ZOU, X.; ZHOU, Y.; YANG, S. T. Production of polymalic acid and malic acid by Aureobasidium pullulans fermentation and acid hydrolysis. Biotechnology Engeneering, v. 110, n. 8, p. 2105-2113, 2013. 